

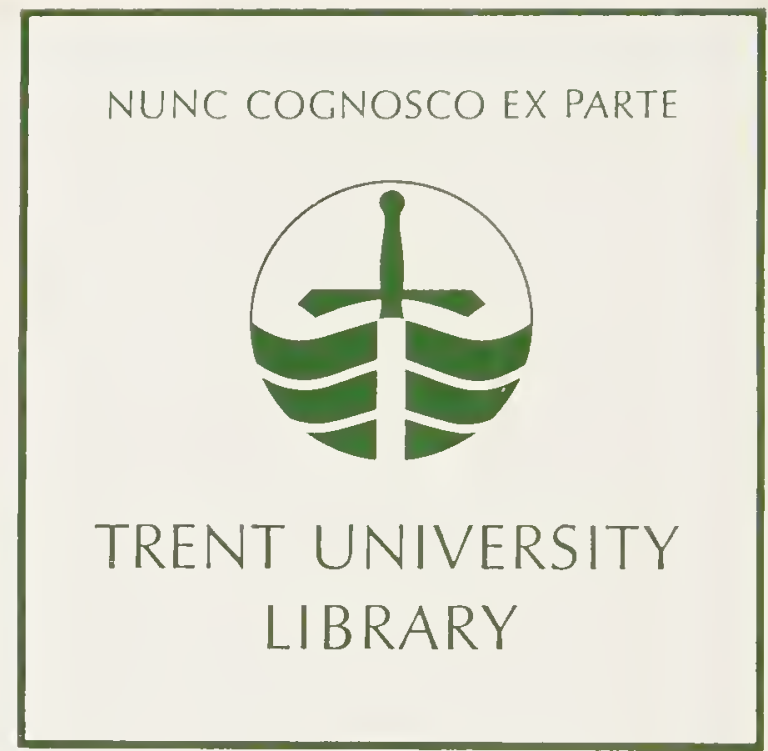

PRESENTED BY

Mrs. H.H. Graham 
Jow HA frater 



Digitized by the Internet Archive in 2019 with funding from Kahle/Austin Foundation

https://archive.org/details/huntingdinosaurs0000ster_a1n3 


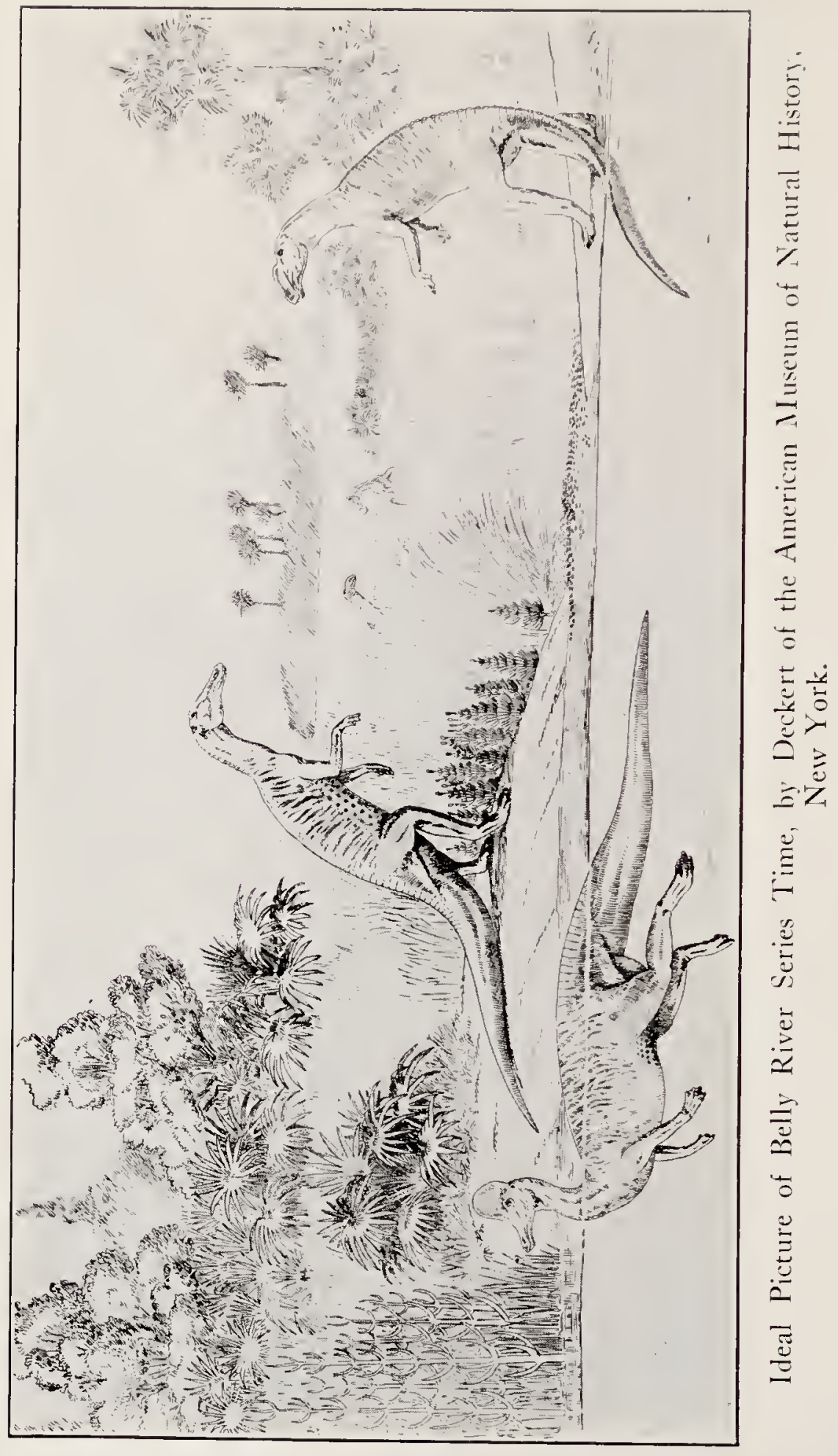




\section{HUNTING DINOSAURS}

IN

THE BAD LANDS OF THE RED DEER RIVER ALBERTA, CANADA

A SEQUEL TO

\section{THE LIFE OF A FOSSIL HUNTER}

BY

CHARLES H. STERNBERG

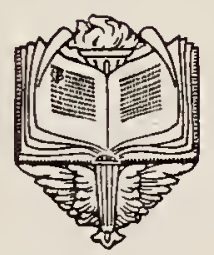

PUBLISHED BY CHARLES H. STERNBERG

LaWRENCE, Kansas

1917 
THE WORLD COMPANY PRFSS
LAWREVCE. KANSAS

DETOT. S8A4 
Copyright, 1917

BY

CHARLES H. STERNBERG

Published, March 1917 



\section{PREFACE}

My Story, "The Life of a Fossil Hunter," pub. lished by Henry Holt \& Co., New York, 1909, met with such a splendid reception that I an: tempted to write a second rolume, especially as I have since that publication with my three sons met with the most wonderful success among the dinosaurs of the Red Deer river, Alberta, Canada. Since 1912 we have been in the employ. ment of the Geological Survey of Canada, collecting fire car loads of the ancient inhabitants of Alberta. We have found many new genera of the duckbilled dinosaurs, those wonderful swinmers of the old lakes and bayous of the Cro taceous period, three new genera of horned dinosaurs, learning more about them than was ever known before, finding that instead of being cowered with bony plates as has been supposed they had thin skins with small scales like mosaic work; then, stranger still, the huge plated dino. saurs completely enveloped in an armor of bony plates, some large, and others small like chained armor, allowing motion to the body. In fact, we are building up a great exhibit of these strange creatures of the past. I propose to write in the same strain as in my other book, but will take my readers to entirely new scenes; to the richest 
Cretaceous fossil field in the world; will tell of our adventures and strenuous labor in the great gorge of the Red Deer river, 500 feet deep, ant many miles in length; of the entire process of collecting, learned by experience through so many years of ceaseless effort; also the work of prep. aration in our laboratory. In 1917 it will be fifty years since I began collecting fossils, the rich results of the past few years are due to the splendid work done by my three sons of whom I am justly proud, and the assistance rendered me by the Geological Survey who have honored every requisition I have made upon them and the results have been far beyond my wildest dreams. No other Museum in the world, except the American in New York, can show such collections as we have made in the last few years. I would like to tell you the whole story. Those of you who have read my other volume and have sent me notes of appreciation I would like to tell you of how much assistance they have been to me, giving me fresh courage when I have been nearly discouraged. I will illustrate the new book with fifty original photographs showing the fossil beds, the skeletons, or huge heads in the rock, the manner of collecting, the work of preparation in the laboratory, and the finished specimen ready for exhibition. We have already mounted the first duck-billed dinosaur in Car. 


\section{Preface}

ada, it is thirty-two feet long. We secured eight skeletons of a new form with a hooded head.

Faithfully yours,

Chardes H. Sterneerg.

Laurence, Kansas. 



\section{ACKNOWLEDGEMENTS}

I wish to acknowledge the great kindness of Dr. I. Hussakof,at that time Curator of Reptiles in the Anerican Musem of Natural History, New York for reading and correcting the first ten chapter's of this book, and for his many kind words and deeds. When I offered to pay for the trouble he wrote me "all the pleasure of being helpful in an unselfish way would be gone if I received pay." Dr. W. D. Mattlens, Curator of Vertebrates in the same Musenm also encouraged 'ne greatly by hoping I would publish my ideal picture of "Ancient Giants" after reading the chapter I sent him under that title. All the rest I am responsible for, as I have had no assistance, and if I liare published any thing that does not please my reader I hope they will overlook it.

How can I thank the Director of the Geological Survey of Canacia, and Deputy Minister, Mr. R. Cr. MaCommell, who has allowed me to use the photographs taken by my sons George and Charlie, to illustrate my pages. The text would have been dull indeed withont them. Neither can I express my thanks for his unfailing kindness to me while I was moler his authority as a member of the Surver. All the photographs (except the Front Piece Figures 1, 2, and 3, which 


\section{viii}

\section{Acknowledgements}

were sent to me by my old friend, Dr. Osborn, President of the American Museum of Natural History, New York. The picture of a Portheus, from the London Illustrated News, the Figure, of a Tylosaur by my son George F. Sternberg. The restoration of Diplodocus carnegie by Mr. C. W. Gilmore of the U. S. National Museum, and the figures 43,44 , and 45 taken last year by my son Levi) belong to the Survey. Mr. Clark in charge of the Division of Photography developed the photographs, and the Terre Haute Engraving Co. made the halftones. Neither can I forget the unvarying kindness of the former Deputy Minister, Dr. R. IV. Brock who first employed me. For the great assistance he rendered me in field and shop. For his earnest assistance to help me build up a great collection of the Extinct Animals of Canada, at the Victoria Memorial Museum at Ottawa, Ontario. I hope these gentlemen and all others who have helped me to that end, will feel themselves included in this letter of thanks.

Faithfully yours,

Charles H. StThrnberg. 


\section{CONTENTS}

CHAPTER PAGE

I. Story of a Monster Fish . . . . I

II. The Teeming East . . . . . . 16

III. In the Edmonton Beds of the Cre-

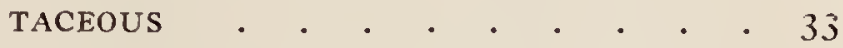

IV. We Explore Dead Lodge Canyon • 49

V. Hunting Horned Dinosaurs • • 78

VI. Plated Dinosaurs . • . • . . 90

VII. The Great Spiked Dinosaur • . . IOI

VIII. A Trip to The Judith River • • . I IO

IX. Another Strange Dinosaur . • . I 20

X. In the Milk River Country • • 127

XI. There Were Giants In Those Days 134

XII. What the Cretaceous Seas Brought

ForTH . . . . . . . . . 156

XIII. The Wonders of the Permian • . i 80

XIV. Conclusion . . . . . . . . 200

INDEX.$\quad \cdot \quad \cdot \quad \cdot \quad \cdot \quad \cdot \quad \cdot \quad \cdot \quad \cdot 225$ 



\section{ILLUSTRATIONS}

Ideal Picture of Belly River Series Time by Deckert, of the American Museum of Natural History, New York.

Fig. I. "Dinosaur Mummy" found by George PAGE.

Fig. 2. "Here the skin is preserved with its complex arrangement of minute scales," . . 5

Fig. 3. In 1909 Charles M. Sternberg discovered this magnificent Triceratops . . . 8

Fig. +. Portheus molossus, Cope . . . . . 9

Fig. 5. Another skeleton George found, to add to the trophies of his hunt . . . . . . 9

Fig. 6. Mr. C. W. Gilmore's wax figure of his ideal Diplodocus carnegie. . . . . 20

Fig. 7. A huge Titanotherium . . . . . 21

Fig. 8. Trachodon annectens, Marsh . . . . 26

Fig. 9. Traveling on Red Deer River, Alberta . 2?

Fig. IO. Steveville at the mouth of Berry Creek,

Alberta

Fig. II. Charlie's carnivore as he found it . . 49

Fig. I 2. Preparing Charlie's Carnivore . . . . 52

Fig. I3. Loading Carnivore with triplex tackle . 53

Fig. I 4. Quarry after Carnivore vvas removed . 56

Fig. I 5. Sternberg's camp three miles below Steveville, Alberta . . . . . . . 57

Fig. I6. Skeleton of Lambe's Stephanosaurus . . 66

Fig. 17. Sections of Stephanosaurus skeleton . . 67

Fig. I8. "I climbed the rugged buttes and ridges" 70

Fig. 19. Pillars cut from the solid rock . . . 7 I

Fig. 20. Outlying Butte over 300 feet high . . . 76

Fig. 21. Levi founded a crested dinosaur . . 77 
PAGE

Fig. 22. Excavation after taking out Charlie's Stephanosaurus . . . . . . . 82

Fig. 23. Charlie's new Trachodon . . . . . 83

Fig. 24. Prepared skull of Gryposaurus, Lambe, Kritosaurus, Brown . . . . . . 88

Fig. 25. The strata of clay thins out to nothing . 89

Fig. 26. Discovery of George's Chasamosaurus, (Ceratops) . . . . . . . . 94

Fig. 27. George's Chasamosaurus, lying in quarry 95

Fig. 28. Levi wrapping Chasamosaurus . . . . 100

Fig. 29. Chasamosaurus Quarry . . . . . IOI

Fig. 30. George preparing his Chasamosaurus . . 104

Fig. 31. Drawing of skull by Weber . . . . IO

Fig. 32. Sternberg's camp three miles below "Happy Jack Ferry" . . . . . . . 108

Fig. 33. Styracosaurus in the bottom of gorge . . 109

Fig. 34. Top view of Styracosaurus, prepared by C.

H. Sternberg . . . . . . . III2

Fig. 35. Charlie's Centrosaurus in the rock . . II3

Fig. 36. Putting Irons on crest of Centrosaurus . 120

Fig. 37. George at work on C. H. Sternberg's Centrosaurus, (Monoclonius) . . . . $12 \mathrm{I}$

Fig. 38. Centrosaurus, discovered by Charles $\mathrm{H}$. Sternberg . . . . . . . . . I 30

Fig. 39. Limb of Gorgosaurus, mounted by C. M. Sternberg . . . . . . . . . I3I

Fig. 40. Quarr yof George's Plated Dinosaur . . 140

Fig. 4I. Packing up a Loveland Ferry 1915 . . I4I

Fig. 42. Badlands of the Red Deer River below Steveville . . . . . . . . 150

Fig. 43. Badlands near Steveville. Photograph by Levi Sternberg . . . . . . I5I

Fig. 44. Badlands near Steveville. Notice cross bedding . . . . . . . . 160

Fig. 45. Quarry with skeleton of Corythosaurus lost at sea 1916. . . . . . . 161 


\section{Illustrations}

PAGE

Fig. 46. Charlie letting his plated dinosaur down 150 feet . . . . . . . . . I70

Fig. 47. Hauling out fossil . . . . . . . I7 I Fig. 48. Urn-like Mass of Rock . . . . . I 80

Fig. 49. Egyptian Sphynx-like rock . . . I8I

Fig. 5o. Dog Cr. Montana. Notice effects of vulcanism . . . . . . . . . I90

Fig. 51. Badlands near Cow Island, Montana . . I9!

Fig. 52. Badlands of the Missourı River . . . 200

\section{ERRATA}

For FIG. 35-Charlies Centrosaurus in the rock, Page 122,

Read Fig. 38-Centrosaurus discovered by Charles H. Sternberg, Page 123.

For FIG. 38-Centrosaurus discovered by Charles $\mathrm{H}$. Sternberg, Page 123,

Read FIG. 35-Charlies Centrosaurus in the rock, Page 122. 



\section{STORY OF A MONSTER FISH.}

\section{CHAPTER I.}

When I wrote the preface to "The Life of a Fossil Hunter," I little thought of the wonderful discoveries and remarkable changes that awaited me during the seven years that were to follow. Now, in a reminescent mood, I sit down to tell the readers of my autobiography, the story of the last seren years spent in the fossil fields, $O \mathrm{I}^{\circ}$ in the laboratory preparing for study, the material that I have collected.

Two seasons my sons and I collected in the Kansas Chalk, the Lance Beds of the old Converse County that is now named Niobrara County, Wyoming, and in the Oligocene, of the same County. Strange to say, however, five years have been spent in the Dominion of Canada, where, with the assistance of my three sons, I helped 
build up a great collection of the Dinosaurs of the Red Deer River, Alberta, under the direction of the Geological Survey of Canada. The present year of 1916, with the help of my youngest son Levi, I have been engaged in the same service for the British Museum of Natural History. As my reader's will bear witness, in the past, I have seen my choicest treasures for forty years leave my hands forever, to add to the glories of museums I shall in all probability never see. When the opportunity came, however, so suddenly and unexpectedly-the opportunity of a life time-to crowll my last days with a monument that only times ravages or the vandal hand of man can efface, in that growing Dominion of the North that promises to be one of the great countries in the boundless Western Hemisphere, it seemed to me like a call from heaven. Though the ties of a lifetime, nearly, that bound me to many a dear friend at Lawrence, Kansas, must be severed: Though I must leave the protecting folds of my father's flag and mine, and I must live under a flag that has waved a thousand years-under a Monarch, in fact-I, a republican of republicans! Think of it! After three years residence in the beautiful city of Ottawa, the capital of all the broad expanse North of the international line, after four seasons of work among buried dinosaurs and three winters spent in the laboratory of the Victoria Memorial Museum of Ottawa, I am free to confess I would not have known so far 
as personal liberty is concerned that I was all this time in the employ of his Royal Majesty George the Fifth of England and ruler of the British Empire. I have learned, I believe, that a man is as much a man amidst the snows of the Lady of the North, under the Union Jack, as under my own beloved Stars and Stripes. Our hopes, our ideals, our aims are much the same.

I will hurry orel the first two years spent in the fossil fields of the United States after Henry Holt and Company published "The Life of a Fossil Hunter." In 1910 we went to Wyoming. On Schneider Creek my second son, Charles M., made the discovery of the most remarkable duckbilled dinosaur the world has ever seen. The Trachodon I described in the last Chapter of "The Life of a Fossil Hunter" was the best one that had been discovered up to that time. Professor R. S. Lull of Yale University in speaking of the specimen George F. Sternberg had found in 1908 says in his paper, "On Ten Years Progress in Dinosaurs," page 210 Proceedings of the Paleontological Society, 1912: "Impressions of the skin of this animal (Trachodon or duck-billed dinosaur), were already known from material in Washington, and from the fragment of a tail collected by Barnum Brown. It remained for the reteran collector Charles H. Sternberg however, in 1908, in Converse County, to bring to light by the aid of liis three sons the most marveously preserved dinosaur known to (Fig. 1) science. Here 
the skin is preserved with its complex arrangement of minute scales (Fig. 2) entirely bereft of defensive armor. Together with portions of the inuscles, as well as the entire skeleton, with the exception of the hind feet and tail. This specimen was purchased of Mr. Sternberg by the American IIuseum and is now on exhibition."

In 1909 Charles M. Sternberg discovered the magnificent skull of a Triceratops, also sold to the American Museum, and mounted there. This is the best skull of this species known, with the notable exception of the Utterback specimen at Carnegie Museum, Pittsburgh. Charlie's specimen was found on Seven Mile creek, two and a lialf miles northeast of the UcKeon Sheep Ranch. The skull was over five feet long. The horns $331 / 2$ inches in length. The crest itself on weathering out was badly shattered, the fragments having fallen from a perpendicular cliff into a sandy ravine and becoming buried in the sand. Thougl we spent much time in sifting the sand through our fingers, Dr. Osbol'n sent us back the next year, when George and Leri Sternberg sifted tons of sand and secured enough additional fragments to enable the preparators at the American Museum to mount the skull in fine condition as is shown in photograph reproduced here. (Fig. 3.)

In 1.910 Charlie was again remarkably successful. He found near the head of South Schneider Creek, a finer specimen even than the famous ont mentioned by Professor Lull. How he found the 


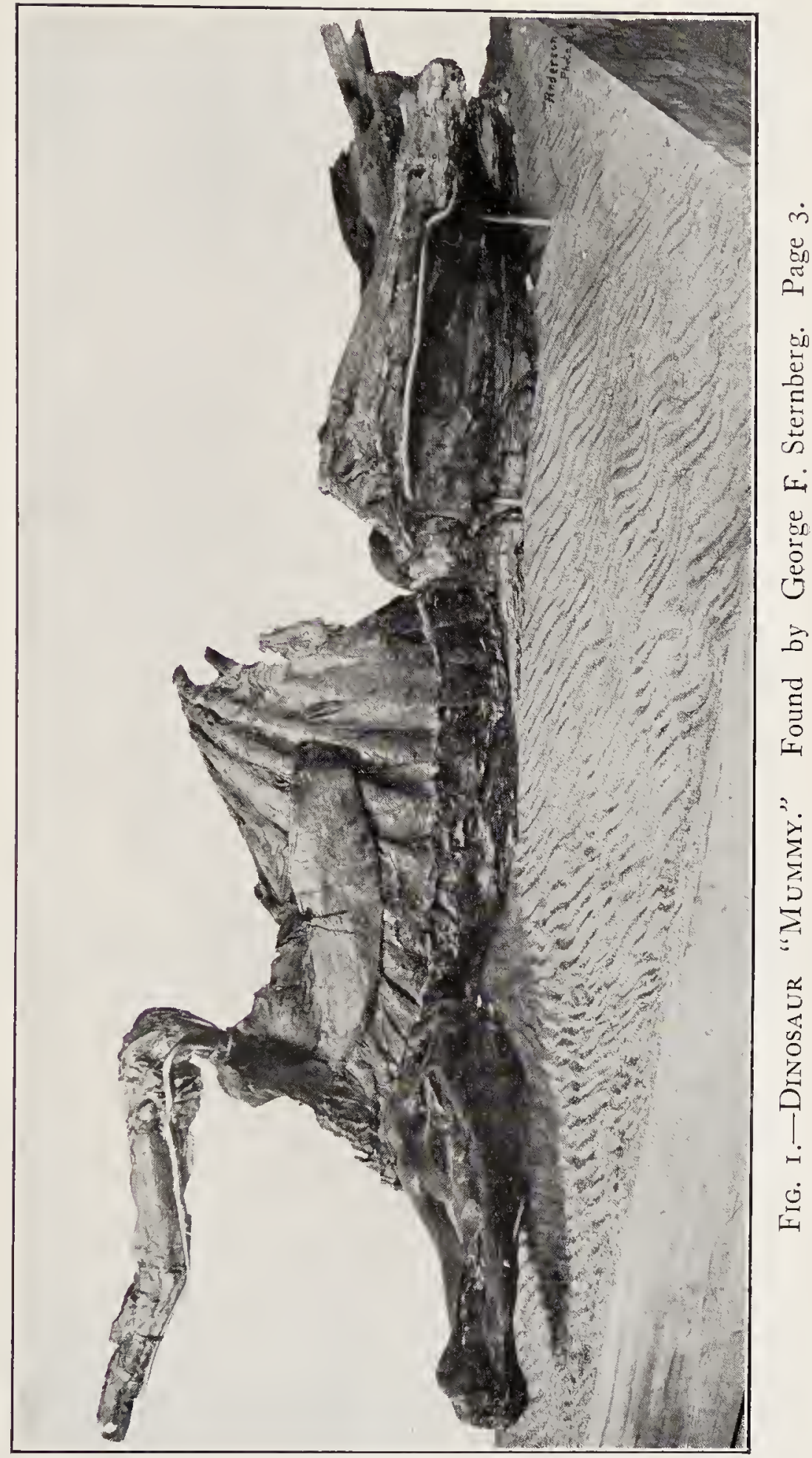




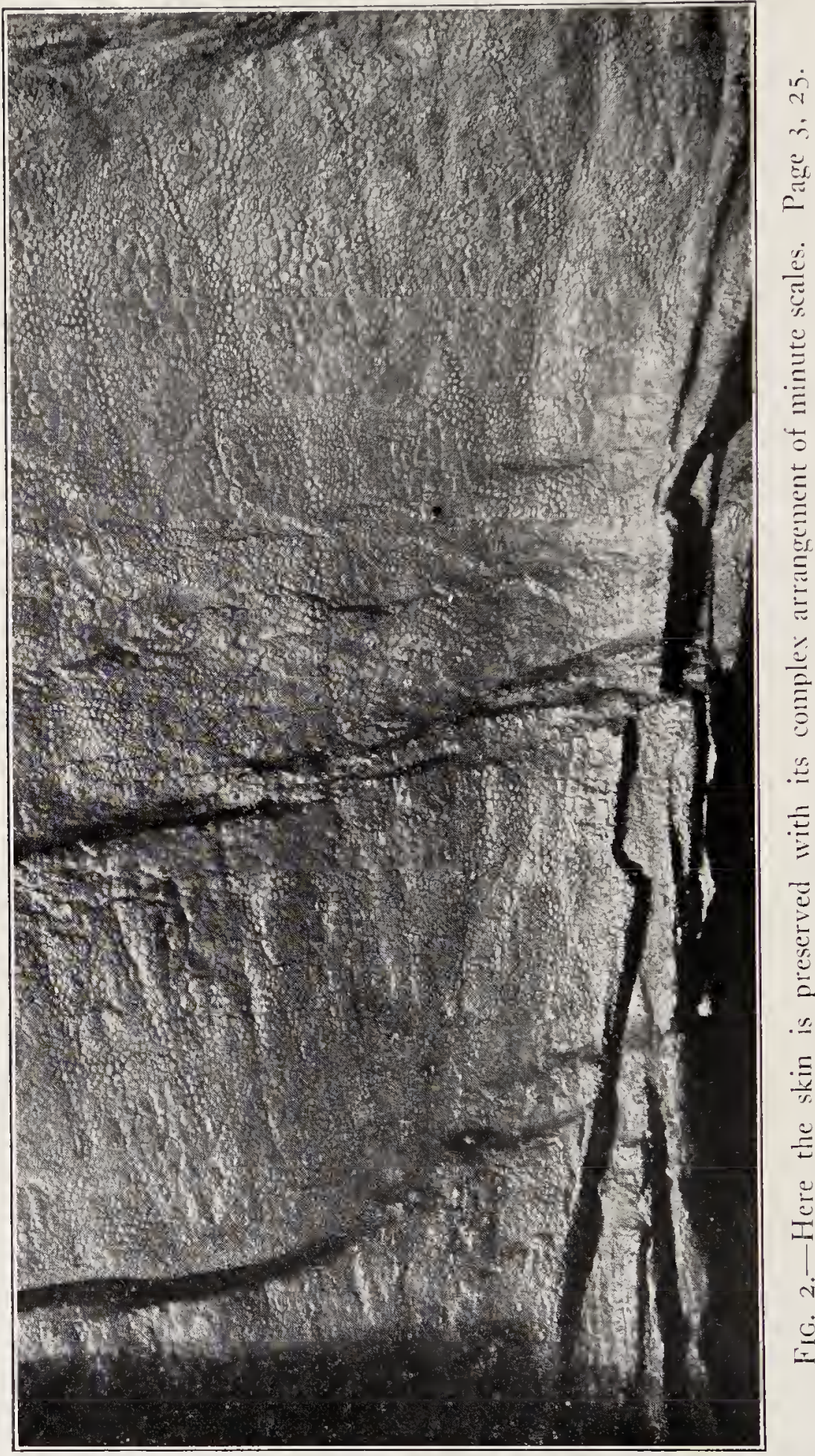


specimen is well worth the telling. He discovered a large part of the tail sticking out of a rounded mass of sandstone; another section was in the ditch below. I was at the time camped on the other side of the Cheyenne River, and it took me nearly all day to return with Charlie who came after me in our one horse buggy. It was a bitter cold evening when we reached the locality, and in order to sleep, we built a big fire of dead cottonwood limbs, and when we wree ready to leave the fire for bed, we raked off the coals and rolled out our bed on the warm earth beneath. We were under a sheltering bank that protected us from the wind. The next day the wind again blew a gale, and we stood on the bluff and swung our picks all day in our effort to get down to the floor on which the skeleton lay stretched out at full length. Our eyes were soon filled with the sand we loosened with our picks; but our enthusiasm knew no bounds, and that evening, I believe, the other boys, George and Levi arrived with the outfit, pitched a tent and cooked us a good meal under corer. It was a big nndertaking however, tw get that dinosaur out of the quarry and haul it to the railway at Edgemont, South Dakota, 75 miles away. It took us two months and a half of tireless effort. The skeleton had evidently sunk after death in quick sand, since the front limbs were lifted up along the sides of the body and rerersed, showing the perfectly preserved webs that covered them. The head, and the neck were 
stretched to their full length, while the hind feet pointed downward. The animal lay on the ventral surface with the abdominal wall spread out. The skull was four feet long. Trunk and head 12 feet and 2 inches and the tail 5 feet and 6 inches. The entire body was covered with skin, not clinging to the bones as in the American Musemm specimen George found in 1908, but cor. ered as if with round muscles, the sand having taken the place occupied by the original flesh. Owing to the great size of the specimen, and as I was determined to sare every particle of the skin, the sectons we took up were rery heary, espec. ially those composing the trunk, one of which weighed about 3,500 pounds. It took considerable skill and the combined strength of the four of us to handle these huge masses of rock and bone, especially as we had no tackle. We learned, however, that with a couple of cotton-wood poles for levers and blocks of the same for fulcrums, we could hoist a section up, and then while the boys held it a few inches above ground I would shorel sand under it and tamp it with my shovel handle. Of course when they loosened their hold to take a new bite, it sank deeply into the sand again, but still we found we had gained an inch or two. Working thus all day we not only raised a section weighing 3,500 pounds four feet in the air, but moved it several feet to one side so we could run the wagon under it and load. I then came to the concluson that if four men with nothing but 
poles, blocks, and sand, could move and handle such a heavy mass that the ancient Egyptians, with millions of laborers and endless tons of sand, could with nothing more than such simple tools have erected the pyramids.

The specimen when boxed weighed nearly 10,000 pounds. I sent it to Dr. Dreverman of the Senckenberg Museum at Frankfort on the Main. I shall never forget the effort I made to induce him to give up the specimen, or take another in its stead. A day or two after I received his acceptance of my offer, I received an offer from Dr. Brock of the Victoria Memorial Museum. He wished me to mount the specimen in Ottawa, and offered me double the price I was to receive from Senckenberg for the unmounted specimen. But it crossed the Atlantic. The last message I had of it, before this awful war cut off all communications, was that the head had been prepared and it was the best of which there was any record.

These two specimens which my party of three sous and my self have added to science, prove conclusively that the duck-billed saurians were great swimmers. My readers will remember that I was coming to this view slowly. In describing the splendid specimen George had found in 1908, on page 276 of "The Life of a Fossil Hunter," I said "I have no doubt that the animal with lungs expanded to their full capacity often swam across streams of water." I was reluctently giving up Marsh's and Cope's ideas; they believed these 
dinosaurs lived on land, feeding off the tender foliage of trees; and I remarked, "The animal could use the front limbs as clumsy hands to hold down branches of trees from which to crop the teuder foliage, or banners of moss." When I wrote those lines I had but a single specimen to draw my conclusions from, and even this not yet prepared, and I had little knowledge of its habitat.

Now after eight rears in the cemeteries of the duck-billed dinosaurs, with the discovery by my party of several new genera, as well as a careful study of theil environment: as recorded in the rocks in which they lie buried, and eight months each year in the laboratory cleaning, mending, preparing and mounting them-my vision has broadened; I have indeed been forced by incontestible evidence to give up my old ideas in regard to their habits and surroundings. In fact Paleontology, like all human science-or rather scientific theories, for the actual facts of science never change-progresses. Evidence to prove certain views seemed conclusive to the old palcontologist; but better collections, trained students and further knowledge prove these views inadequate today. Entirely different views are held now, as in the case of the duck-bills, for instance. These lived in the water instead of on land, and consequently they had thin skin and strong paddles, or rather webbed feet. 


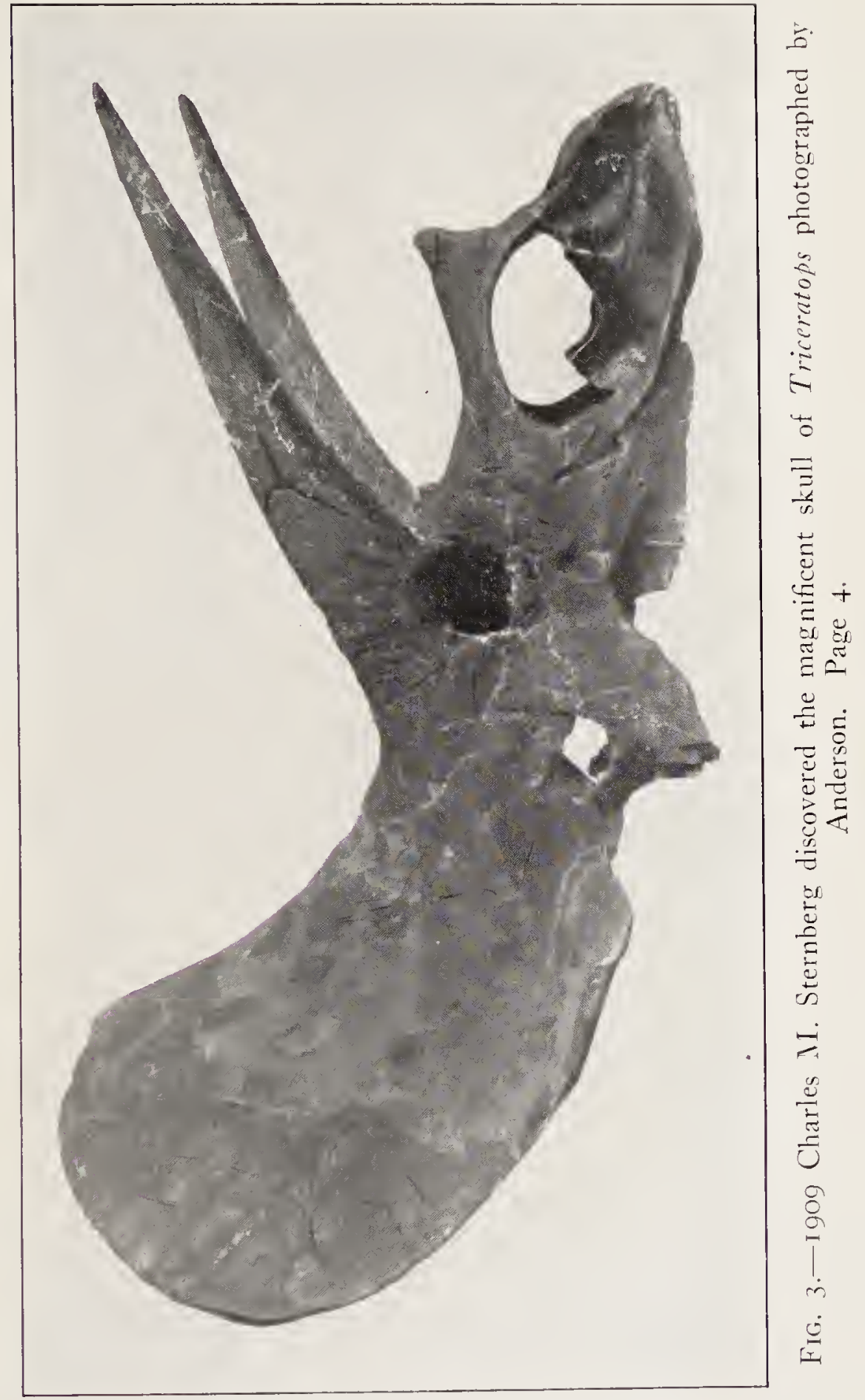



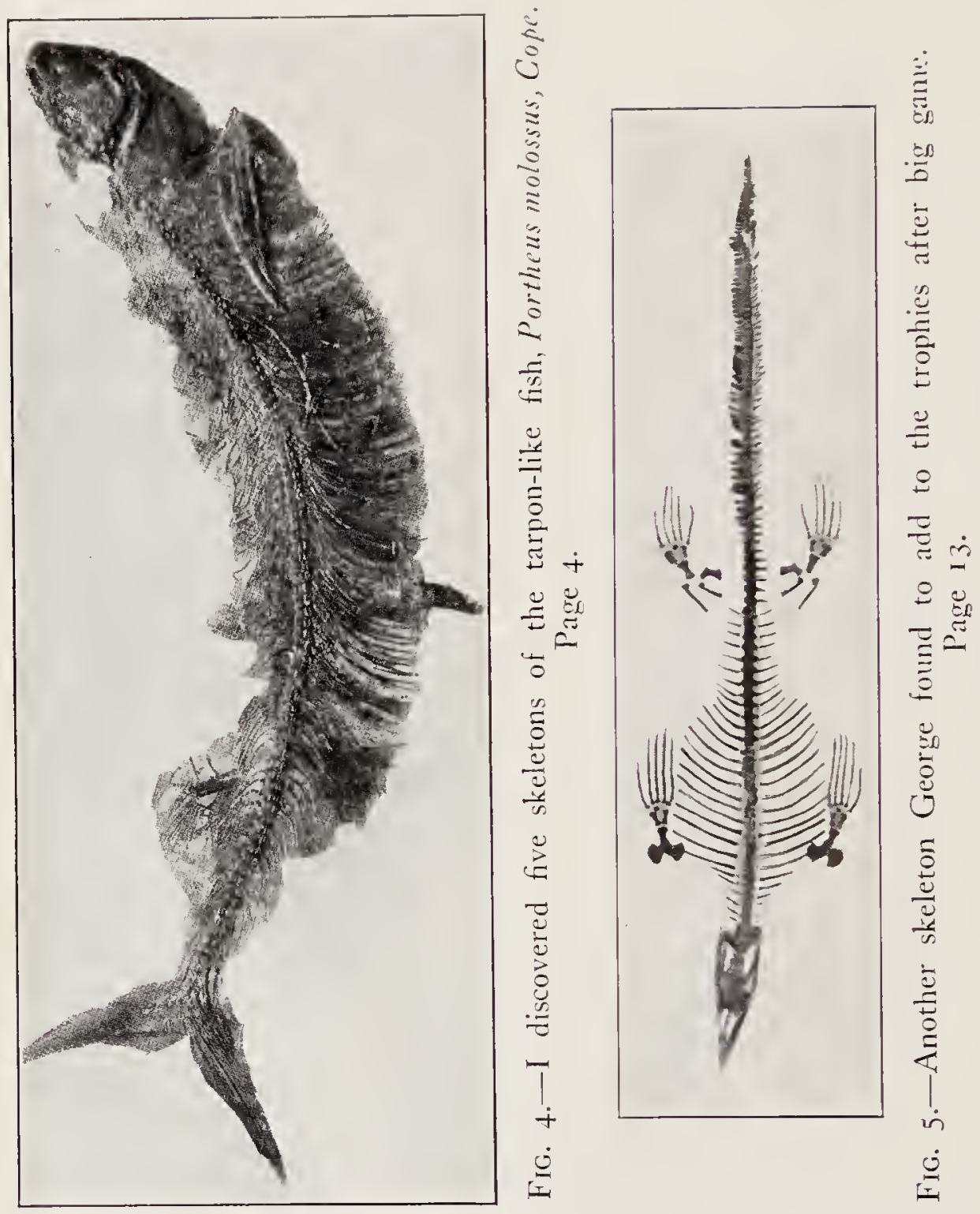
I also discovered a wonderful deposit of figs a few rods from the Trachodon quarry. They fell in sand among teeth and bones of reptiles and fishes, as well as the impressions of rushes and other aquatic plants, and shell fishes. The sand packed solidly around them, and when they decayed their form was firmly molded in the sand. The cavity thus formed was filled with sand, and an exact cast of the figs was produced. Until then, less than a dozen fossil figs were known to me. I also discovered five beautiful palmetto palm leaves 18 inches in width, showing that the country at the time they grew was like the everglades of Florida, ridges betreen great marshes, through the center of which ran sluggish streams almost at a level with the near-by ocean. The water was beyond tidewater, however, it was sweet.

In 1910 I found three Triceratops skulls and George one. Two of them went to the Senckenberg Museum to make a couple of mounted skulls for exhibition. We also secured much Trachodon material in addition to that already mentioned, a large part of a skeleton going to the British Museum of Natural History. George also found the most perfect specimen of a Trachodon tail I had seen up to that time. I sent it to Dr. Marcelin Boule for the Paris Museum of Natural History.

During the winter of 1911 we were preparius a huge skull, some seven feet long, of Triceratops. for the Victoria Memorial Museum. Later, in 
the spring I was away, and Charlie was at work on it. One evening lie had left the shop to go home when a Kansas cyclone struck the building and shoved one of the brick walls in as easily as if the building had been a house of cards. The weight of the brick falling on the skull not only crushed it so badly that it could not be restored and had to be thrown away, but it drove the heavy tailor's table it was on through the floor Mr. Constant the owner of the building saw the storm coming and ran upstairs to shut the west window. But before he could reach it the wail fell in and he had to run for his life up the falling floor, and fortunately reached the steps and got out of the luilding safely. Though the loss of so valuable a specimen that had cost me much time and labor was bitter indeed, the thought that my son had so narrowly escaped with his life made me more reconciled to the loss. I have, as already related, both seen, and been in cyclones, but this was the first one that ever destroyed such a valuable fossil for me. In the same building, but farther towards the east, we had a great fish (Portheus), skeleton 14 feet long. But when the floor from above fell in, the rafters covered it in such a way that it was not injured, and though corered with lath and plaster, it came out without a scratch, and is now mounted in the Victoria Memorial Museum. Our camp was visited by George's wife and babies in 1910. We were camped on the Cheyenne River: 
and it was a great comfort and pleasure to have. a woman in camp, and we soon noticed a change in the culinary department. It seemed like home to have a daughter and grandchildren iu this desert land, and when we came in from a hard day's work in the fossil beds they helped make us forget our labor and our care. Thesf; records of work in the Laramie, or rather as they are now called, the Lance beds (from Lance. Creek in the immediate vicinity), show plainly that persistent, untiring efforts in a field (that was supposed to be exhausted by other explor. ers), by trained collectors, will meet with good results. Thirteen Triceratops skulls, I believe, were recorded by Hatcher, who with others spent vears here. We not only secured six Triceratops skulls, bnt, what was worth far more, the nearly entire skeletons of two trachodonts wrapped in their skins, giving science an entirely new conception of these dinosaurs.

In 1911, I sent George to western Kansas with a party to collect in the Chalk and with wonderful results; for though I had secured four skeletons of the famous Tarpon-like fish of the Cretaceous, named Portheus molossus by Cope, he succeeded in finding the most complete skeleton known to science, now mounted in the British Museum of Natural History, in London. Mr. Pycraft, has pictured it in the London Illustrated News for March 1, 1913. "The giant to which I refer now" (he says), "has been dead a 
very long while, a million years or so [over $5,000,000$ C. H. S.]. It remains in a most extraordinary state of preservation-will be found in the reological Gallery. Measuring just fourteen feet in length, it must have weighed between four and five hundred pounds [a thousand like-ly C. H. S.]. It was obtained from the chalk of Kansas, and has quite a remarkable history. It was found by Professor Sternberg who has achieved a world-wide fame for his discovery of fossil fish and his quite amazing skill in digging his finds from the rock in which they are embedded. The specinen was found [by George F. Sternberg], exposed at the surface of the ground, and was much the worse for wear-andtear of wind and rain and sun. But Professor Sternberg was equal to the occasion. For just as there are two sides to every question, so there are two sides to every fossil the resourceful discoverer determined to get at the other side of this very stale fish ; for the exposed side was useless. Accordingly he covered it with a thick layer of plaster-of-Paris and when this was set he proceeded to dig out the fossil from the bed of chalk. This accomplished, he cut away the rock from the specimen, and eventually succeeded in exposing the whole fish." [The ;underside at least C. H. S.] (Fig. 4.)

I lave quoted Mr. Pycraft at length as he has given the facts about as they occurred except only in giving me, instead of my son credit for the dis- 
covery. Why did this monster fish whose remains are not only abundant in the thousand feet of Kansas Chalk, but fragments of whose skeletons have been found in many parts of the world become extinct? From my long experience in the fossil beds I most surely believe that he had his day and disappeared, as has the Moa, and Great Auk, and many other species. I have collected redwood leaves and cones from the Dakota Group, Cretaceous, in Kansas, and in the Upper Cretaceous of Alberta, and Wyoming. Now however they range over a small territory along the Coast Range of California, and their days are numbered.

Animals come on the stage of life, exist for a greater or lesser period as it may happen, and then disappear; and the old saw "that every dog has his day" is literally true of the past as of the present. Another fine skeleton George found, to add to the trophies of his hunt after big game, was a beautiful little Tylosaur, or ram-nosed mosasaur. It was twelve feet long only, but was very complete indeed. This also went to Senckeuberg Museum. (Fig. 5.)

In 1911, a young man I had employed, Mr. Jasperson of Lawrence, Kansas, found a fine skull of a Triceratops. Charlie prepared it in the same region since he had taken a homestead for a ranch, married, built himself a house, and spent the winter there, not only preparing the skull for the Paris Museum, but in cleaning the bones of 
at great Titanotherium, I had discovered near Seaman's Old Ranch in the Seaman Hills. The fall of the same year, my sons, Charlie and Levi, and I with our assistant Mr. Jasperson, explor ed a new region in the Oligocene, on Plum Creek, 25 miles North East of Lusk, Wyoming, Niobrara County, a few miles south of the Lance Creek beds. We found an old river bed with its flood plain exposed on either side. It was wonderful indeed to gaze on the dry bed, that had been cemented together into solid conglomerate, of gravel sand, water-worn fossil wood and bones, while the old flood-plains were as real, (though solidified now), as if they were flooded, but yesterday. This flood-plain had been scarred, however, by ravine and canyon, ridge and bluff, that had bi-sected and thus exposed more of the contents than in the days high water covered it. Scattered everywhere was the richest harvest of fossil mammals I had ever seen, before or since. On the 11th of September, I secured the now famous skeleton of a huge Titanotherium, already mentioned. George and I mounted it the next winter in the Victoria Memorial Museum of the Geological Survey of Canada. The first great mammal to be mounted there. It stands 6 feet high at the hips, is 11 feet long to drop of the tail, 4 feet wide at the hips. Over the flood-plain of the ancient river bed, that cut diagonally across the country, and in the Seaman Hills, we secured great numbers of Oreo- 
dons, a hog-like creature that once lived in great herds, I found myself fifty skulls, and the boys a hnndred more.

A large number of these specimens were purchased by the Survey and are preserved in the Musum at Ottawa. The Miocene (Oligocene) beds are extensively exposed. Sculptured by wind and sand, rain and frost, into great square towered buttes, or oblong ones topped with a thick rock that weathers into perpendicular escarpments 20 feet or more in height, making very pleasing scenery. Below the hard stratum, are several hundred feet of greyish marl, some beds with more clay than others, which weathered into small chunks of clay, that covered the rocks, or others again disintegrated into dust. Other strata contained considerable fine sand, greenish in color. The lowest rocks of all, a purplish marl, rested unconformably upon the chalk of the Niobrara Cretaceons, filled with the typical Ostrea congesta, an oyster shell no bigger than a cent piece. Some of the canyons cuc deeply into the chalk, put me in mind of those in the Kansas chalk with which I was so familiar. 


\section{CHAPTER II. \\ "The TeEming East"}

Leaving Charlie and his wife on their ranch, Levi and I returned to Lawrence, George and I prepared the material for sale. As I had sold a 20 foot Platecarpus, George had found during the summer, a 14 foot fish, and the Titanotherium skeleton to the Victoria Memorial IIuseum at Ottawa with the agreement that I was to mount them, I took my son George with me on a trip to the "Teeming East," we left Lanrence on the 17th of March, 1912, by the Pennsylvania Route. After leaving St. Louis we passed through the level reaches of southern Illinois, crossed the Mississippi. The farms along the low lands were covered with water. Farm houses with ornamental trees around them were pleasing to look upon. In places the land swelled into gentle curves with groves topping the rounded elevations. The less pretentious houses occupied by renters were sprinkled in among the nobler buildings. Snow was still lying on the open stretches. Great wood piles attested to the fact that they had not destroyed all the timber. Woods of black oak, were still common. Straw stacks and corn shocks were not very common, 
showing the silos had gathered in all the green stuff, and the long winter had consumed the straw. Everything available for food had been fed to the cattle.

As we go farther east we got among hills with narrow valleys, we cross a river from the north, likely the Waskaskaia, with canal beside it, but both are beneath a flood of water making one great stream. Everywhere are old stump fields: showing the destruction of timber-that once covered all the land-is still in progress. In a decade all will disappear as there is no young timber to replace it. So man destroys his best friends. Not a single rock did I see across Illinois. East of Casey we passed the great oil fields of Indiana; in the field everywhere were the silent pumps at work, attached by wire to an engine. that drives a number at once. The oil is pumped into pipes that in turn carry it to the great tanks many miles away. They covered acres of ground, each tank holding many car loads of oil. At 10 A. M. we reached Terre Hante, where I noticed a huge Court House crowned with a high dome. The country roughens as we go eastward. There are many fine homes with elevated water tanks too, showing that the farm houses are provided with the modern improvements. What more can one ask, with daily mail and telephones in every home? So we swing nerrily along through the great coal fields of Indiana. Everywhere we see the shaft and elevator 
with cars loading on the tracks, there are no storage buildings; if the miners stop work a week or more the consumer must suffer. Here too I noticed the ruthless hand of man among the trees. They are cut down to lie and rot on the ground. We pass through sand hills, and belts of timber, there are more rail fences than in Illinois, where the last ones are being cut for posts for wire fences. They always follow the destruction of timber. At $2: 30$ P. M. we are in Indianapolis. As we enter Ohio beyond Richmond, we observe the improved condition of farm houses and barns, and we see some fine residences of brick and wood. Even the posts along the roads are painted. They have quantities of drainage tiles scattered around preparing to drain off the water, as the ground is soaked from the melting snow. So we speed along, and when we wake in the morning we find ourselves in Pennsylrania among the Allegheny Mountains traveling down Monongahela river, towards Pittsburgh. Tow. ering mountains on either side the rapid streams covered with second growth timber with but few houses. The rocks that have been metamorphiser by heat, are tipped up at all angles, often on edge, or leaning against the mountains as if for support. At last we reach the Smoky City, at the head of the Ohio River a wonderfully rich city. But her millionaries never made their money out of the ground from which they were taken, but from the bowels of the earth. They have delved 
like Vulvan among the Black Diamonds, IronOre, Gas and Oil.

Here the great Steel King Carnegie has dug out his countless millions. Every where the red furnaces belch forth smoke tinted with the glow of the molten mass below. Sometimes gorgeous colors flare out upon the night, or columns of smoke black as midnight ascend and belly outward. Many smoke stacks throw out their fumes until every thing in the narrow valley, the most expensive marble buildings, as well as the humblest huts, are covered with an enamel of a uni. form dirty color.

On the 19th of March I stood on the bridge between Carnegie's Institute and his Technique School, a noble bridge of cement. The Institute, or Museum is beyond my feeble pen to describe. The entrance to the Hall of Music on the West, is one of the noblest of human monuments; the floor is of colored inlaid marble from the famous quaries of earth, with great pillars of marble supporting balconies, twenty or more columns costing $\$ 8,000$ each. The balconies and walls are inlaid with gold. The magnificent building cost 6,000,000 dollars. Every moment I could spare was in the Paleontological Museum, among the skeletons of animals which have disappeared from the earth of today to return no more, except as life is breathed into the dry old bones by hunters and students, who have given their life to their collection and study. 
One of the most famous and world renowner here, is Hatcher's Diplodocus carnegii. It is seventy-two feet long and stands twelve feet high at the hips. Casts of this noble specimen have been sent to many of the State Museums of Europe. Mr. Hatcher told me that he received a cable from: Mr. Carnegie once in England asking him what it would cost to make a plaster restoration of this specimen. He wired back "ten thousand dollars" and immediately received orders to go ahead and make the restoration. This was presented to the British Museum. But Mr. Carnegie's liberality luas known no bounds, and many of the great museums of Europe, have received reproductions. At this writing, however, I am glad to say that the famous collector and student, Mr. Douglas, has discovered a still larger specimen, as I remember, eighty-two feet in length and sixteen feet high at the hips. The last time I was in The Carnegie Musenm it was rapidly being completed for exhibition. Hatcher's specimen was found in Albany County, Wyoming. One of the remarkable things about it is the long neck and tail that lengthens out in a whip-like lash. The head itself is very small with teeth above and below for nipping off the tender tree moss, or other succulent herbage, on which it evidently fed. But it seems incredible, that such a small head could feed so luuge a creature. I have always been opposed to the restoration that has been made of a number in a swamp. When we all know that a lizard of 


$$
4
$$




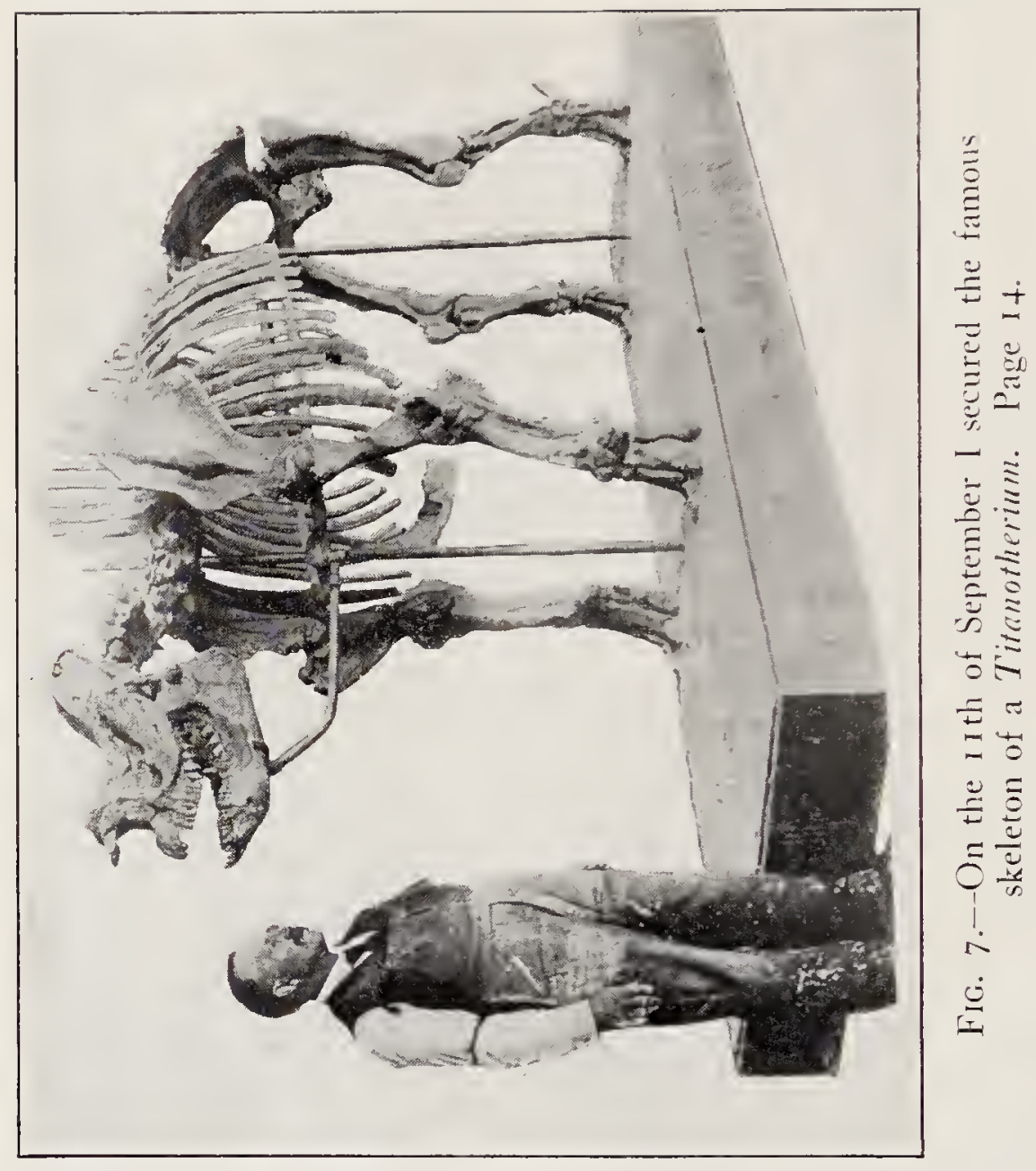


such gigantic proportions, would certainly sink out of sight, as some of them in the illustrations are in the act of doing (See page 79, "The Life of a Fossil Hunter.) I believe the idea of Prof. Marsh that the huge body needed the support of water to buoy it up, is untenable. If they ever went into a body of water to bathe, there would have been a gravely bottom, with no acquatic: plants growing in it. Brontosaurus is another genus of the same family, the Thunder Lizard, of Professor Marsh, who imagined that his tread on earth shook it, and produced a sound like the roll of distant thunder. It has been the dream of $\mathrm{my}$ life to take up some of these gigantic Jurrassic Reptiles but as yet I have not had the opportunity. Every thing in Carnegie Museum of Fossil Vertebrates is dwarfed by the great Dinosaur named after the Iron King. (Fig. 6.)

Another remarkable skeleton is Morophus, a toed ungulate about twelve feet long, and eight feet high. It has a powerful neck, a head resembling a horse, while the coffin bones are cleft down the center. There is a beautiful three toed horse skeleton two feet high, and many other splendidly mounted skeletons of the extinct animals of the west. I was delighted to see my specimen of the great turtle, Cope's Protostega gigas, The First Great Roof, mounted here, as well as the Clidastes and a great fish I sold to Mr. Hatcher just before his death.

But time would fail me to tell of the many 
delights of Pitssburgh. I was especially interested in the Fern Tree Group from Australia. Gigantic tree-ferns they were, and it seemed to me I had gone back millions of years, to the Tree Fern Forests of the Carboniferous.

On the 25th of March we went to Washington and were the guests of my brother, General George M. Sternberg at 2005 Massachusetts Avenue. I had not seen him for years.

I met for the first time Mr. C. W. Gilmour, Curator of Fossil Reptiles, and Mr. Gidley, Curator of Fossil Mammals. In the National Museum I went over with them the grand mounts in the Museum. Among them the first example of a mounted skeleton of Triceratops. They have a wealth of T'riceratops skulls and other material, collected largely by the late Mr. J. B. Hatcher. Here also are groups of smaller dinosaurs, and of mounted skeletons of the Duck-billed form, and many mammals. We pass. ed a most enjoyable time here also.

They were mounting a fine skeleton of a great Stegosaur, or Plated Saurian, one of the most unique of the dinosaurs. The huge dermal plates of bone that line the back bone alternately, in double rows, are often two and a half by three feet in size, while the enormous spines that stick out from the top surface of the tail, are, some of them, over two feet in length. Since that enjoyable March, they have mounted this noble dinosaur as he lay entombed in his rocky cem- 
etery, enough of it removed to show the bones in bold relief.

On Saturday we went to the National funeral of the sailors and marines, who lost their lives when the Maine was blown up by out side explo. sives, in 1898. This was the most remarkable spectacle I have ever seen. I stood at the Army Building and looking up Pennsylvania Avenue to the Capital. It was filled with marching men and the sidewalks were crowded with people. First came a platoon of monnted police clearing the crowded streets for the procession, consist. ing of troops of Cavalry, Artillery, Infantry, of Sailors, and Marines, and the Grand Army of the Republic. They escorted thirty-two caisson.s on which rested donble coffins of the martyrs of the Maine, completely hidden beneath a wealth of flowers. Several bands played funeral marches. The great column was reviewed by the President. A cold rain set in that lasted all day, but the soldiers made the solemn march to Arlington through it all, in full dress. The brilliant uniforms of the officers were unprotected from the violent down-pour. As the procession was hours in reaching the Cemetery, we went ahead to Arlington House, which stands surrounded with grand old trees on an elevation overlooking Washington, across the Potomac. It was too wet to look at the cemetery, where thousands of the soldiers of the Union perished, that our country should continue one and inseparable, 
with the foul blot of slavery washed out in the blood of our patriots. In one to mb are the bones of 2,000 unknown dead gathered from the battle fields, who live in story and died that we might live and enjoy the blessings of American Citizenship, the most prosperous nation on God's greer earth. Printed on a white board is the poets tribute to the soldier dead:

"On times eternal camping ground

Their silent tents are spread,

And glory guards with solemn round

The bivouac of the dead.

The muffled drums sad roll has beat

The Soldiers last tatoo.

No more on life's parade shall meet

The brave the fallen few."

They laid the Martyrs to rest, with the countless soldiel's and sailors of the great Republic dead "Peace to their ashes," Monday we left for New York.

It would be useless for me to attempt to describe the wonders of the American Museum at 77th street and Central Park West, in New York City. There is no museum on our continent to compare with it as far as I know, and I have visited nearly all. I have rarely been able to spare the time to visit any part of it, except that of Vertebrate Paleontology, neither have I time now, to describe their most noted specimens, and since Barnum Brown has added six car loads of the wealth of Dinosaur material, from the Ed- 
monton and Belly River series of the Red Deer River, Alberta, no man can measure the wonders of her "Animals of the Past." How grand for science, to have such a man as Professor Osborn its President, a man who has given his life and wealth to augment its riches from "The Story of the Past," and those other men like Morris Jessup, who have given their millions into the treasury. I was proud indeed when I entered her walls to know that the nucleus of those vast collections was the "Cope Collection," and to remember that I had been a contributer to that collection for seven vears of the best, if not the most fruitful years of my life. I saw here the strange ladder-spined lizard I collected in the Permian of Texas, part of my John Day River Collection of Oregon, etc. But what pleased me most were the nore perfect specimens of a horned and duck-billed dinosaur from Wyoming, and the great fish Portheus. Here lies the prepared specimen of George's Trachodon annectens, wrapped in its skin as in a mantle. Here, too, in the Invertebrate Department, is the great Inoceramus shell 3' 4"x3' 7" in size. The second shell of these huge dimensions I sent to Tülingen University. Although they strew the rocks of the Kansas chalk in great numbers, they are always broken into small pieces, and these are scattered by the winds of heaven. It seems inipossible to preserve them. But George and I learned the secret, and after finding a shell with lips or hinge 
exposed, we carefully removed the loose chalk above it, then put a frame of two by four lumber around it, in which we poured plaster. On hard. ening thus stuck securely to the shattered shell, holding the fragments in place. Then we dug beneath and turned over the panel, and in the shop removed the chalk, leaving one side of the shell exposed in the solid plaster.

From New York I went to Yale, and met Professols Lull, Schuchert and Weiland, and thr. preparator, Mr. Hugh Gibbs. What a splendid time we had in what the oldest American Paleantologist, Prof. S. W. Williston used to call "it Paradise of Dry Bones." We saw the treasure Prof. Marsh luad gathered through so many years, some of them the most famous among fossil vertebrates. Time or space would not allow me to go deeply into the study and description of these wonders of creation. Dr. Weiland told me that if five of the most perfect fossil turtles were chosen from all the museums of the world, his great extinct monster turtle, Archelon ischyros. from South Dakota, would rank first, and thr one I sent him from the Kansas chalk would be second in the list. You may call it egotism, tr recall these delights, but it is the very spice of life to know that years spent in the barren and desolate fossil fields of North America, have not been barren of results. Please remember, if I am still collecting in the year of grace 1917, it will mean that $I$ have been a collector, or if you 


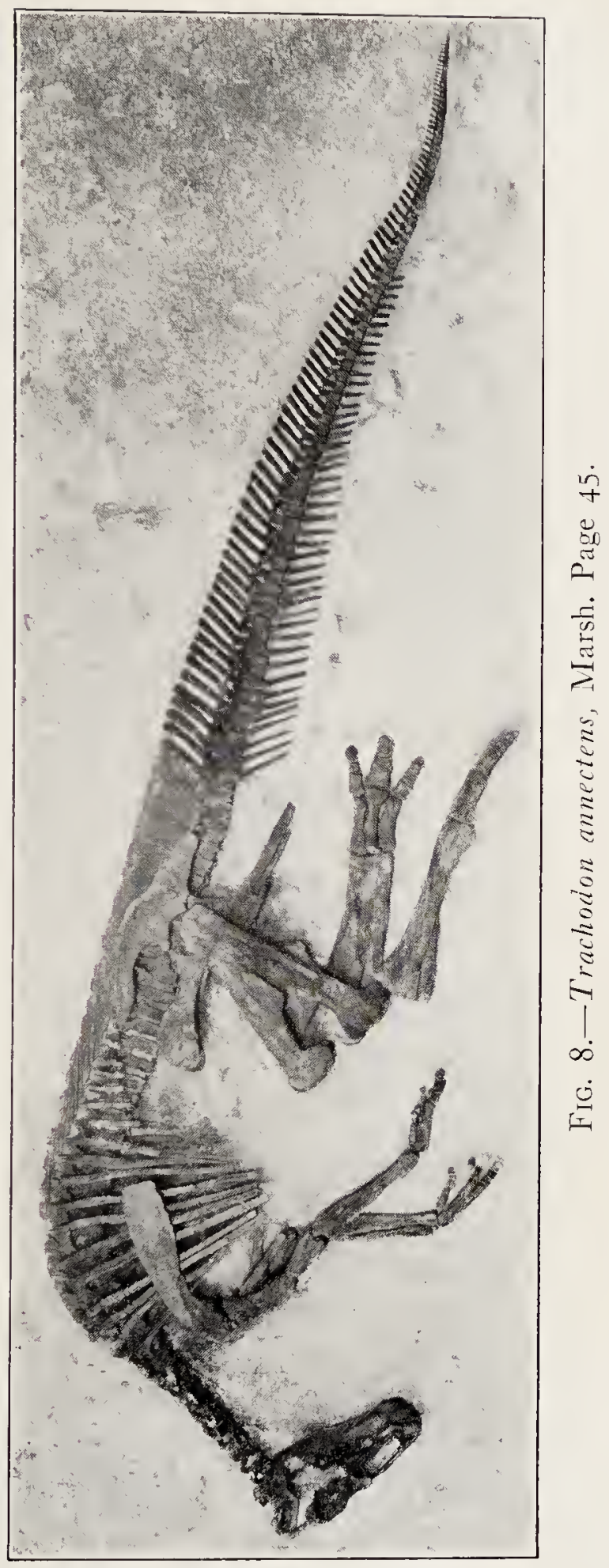




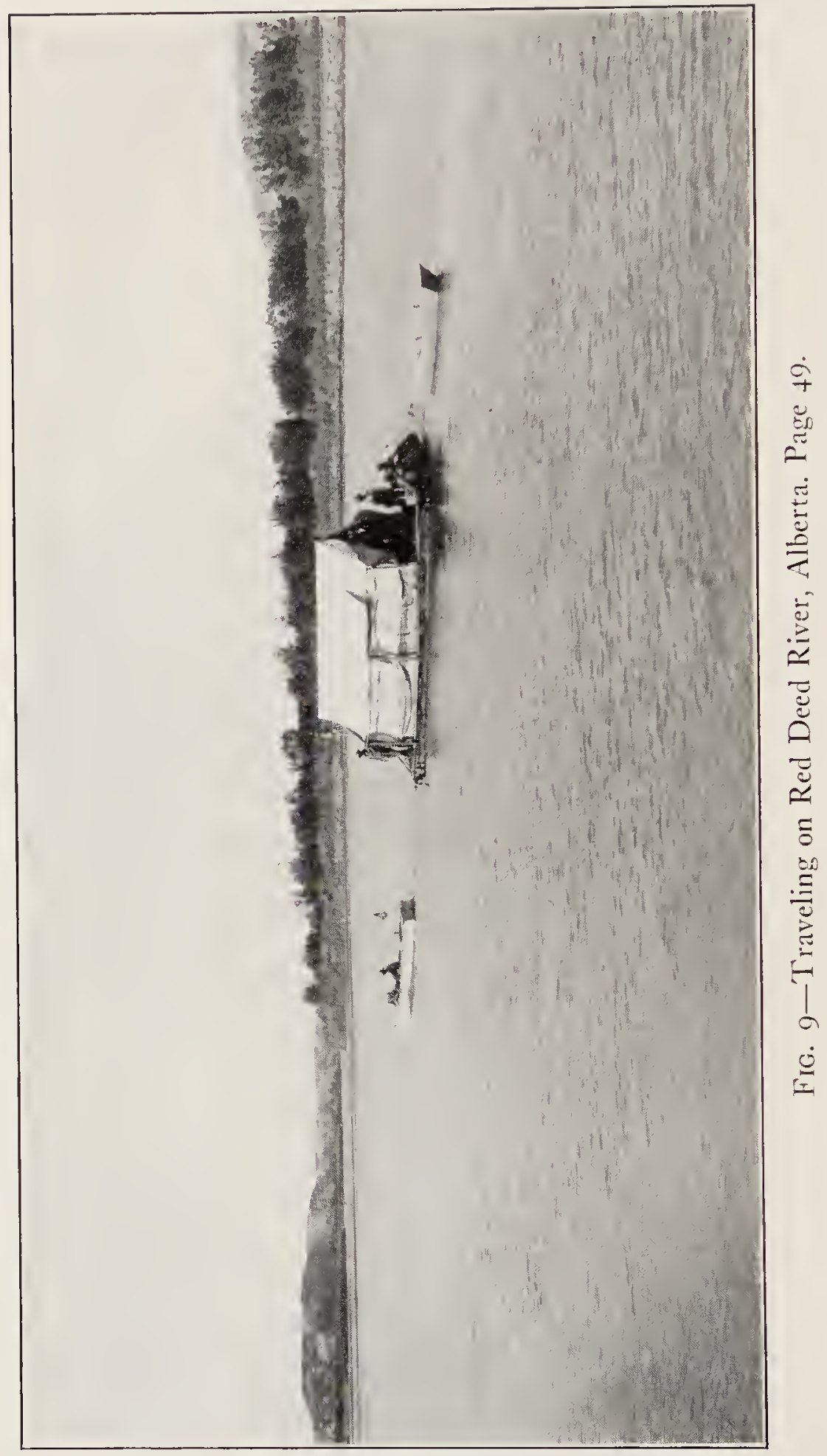


please a Fossil Hunter for fifty years. So I should be excused, if I bring before you the choice of the big game I have gleaned through half a century. We visited these great museums not only for pleasure, but to learn something about: the processes of making "Open Mounts," for I must confess, neither George or I had ever done this kind of work, although I had bound myself with George's aid, to mount the Titanotherium skeleton in this way, that is, mount it free from the rock in which it was entombed. Fortunately, the preparators told us of many mistakes in their own mounts, and warned us not to fall into the same pits. Unfortunately, howerer. they were not mounting a titanothere, at the American Museum and the one we studied was among their first mounts, and they have been improving on it ever since. With the maxim of the late Professor Cope ringing ever in my ears "What man has done he can do again, and he can do a little more." With the little knowledge we had gained we crossed the International Line, and found ourselves in Ottawa, Canada. We found that the great room that was to be the exhibition room of vertebrate fossils, was filled with boxes and barrels, and there was not a tool in sight. As I was obliged to mount the Titanotherium at my own expense, I conld not afford an elaborate machine shop. I remembered how Charlie in a little log cabin on Old Woman Creek, Wyoming, was preparing a great skull of a lorned dinosaur. 
A Triceratops, for the Paris Museum, with little more than a knife or two, a few chisels and brushes and sacks of plaster, in a room that had only about two feet of extra space around the skull. Also with similar tools, he had taken tho skeleton of the Titanotherium, out of the hardest kind of rock, we certainly, with a few simple tools should be able to mount it. We did it too. We were indeed handicapped. For an anvil we secured a disk of solid steel, a strong vise, the necessary half oval, and round steel, and iron tubing for supports, etc. We made a great sand table first, and laid out on it the skull and column to get the pose, often getting above it and moving a bone here and there until we were satis. fied. We then cut a board so as to fit the contour of the under part of the column, as we had arranged it on the sandtable. This board was fastened to bases by two half round pieces of steel that were fastened to either side of the board in pairs, one in front, and one behind. These coming together beneath made a round rod of iron that passed into iron tubes a little larger, and held them where we wished, with thumb screws. These supports in turn were fastened to broad bases, so they would not fall over. We took a cast of the under side of the centra of the vertebrae, and covering the board that served as our model with moulding wax, we stuck the vertebrae in on the central line, giving the exact pose the column had on the sand-table. An iron rod was 
bent so as to pass down the neural canal. The skull too, was fastened to this iron support, which in turn was fastened to the strong sujports that were to secure the skeleton to the base. Although this is the most complete skeleton of a Titanotherium with which I am familiar, there were several missing bones. We secured a box full of duplicate material from the American Museum, and we succeeded in finding nearly enough to complete some of the feet. We found however, that we had only one femur and one radius and ulna. So we were obliged to attempt another trade with which we were not familiar, that of modeling the missing bones in clay. And then making a cast of them to replace the missing ones. When I attempted to make a femur in wax using as my model the bone we already had, I found difficulties I had not bargained for. It would have been comparatively easy to have made a copy of the one we had, but it would have been useless. In other words I must make one exactly the reverse of the model, i. e., if there was a great trochanter on my model, I must put it on the reverse side on my wax copy, or as I told George, I must think exactly opposite to what the model was, like thinking backward. In other words the mental picture I must follow, would be the reverse of the femur I was looking at. It seems we both overcame these difficulties. We made one mistake however, I have been sorry for, and hope to rectify, and that was we followed 
the old mount in the American Museum, covering the iron half ovals that were fastened to the limb bones with plaster to give the skeleton a standing pose. I am sure it would look better if the iron was exposed. Some time we will rectify that error. I can never give you a pen picture of the difficulties we met with; they were legion. We overcame them however. Among the most important, perhaps, was the fact that we had to. work in cold iron, as we could not use a forge on the fine floor of the Exhibition Room. If we bent the rod a little too much it would break. Then it was very hard to give the exact shape it must have, or the skeleton would be distorted. Any thing the least out of line, you know, is quickly detected by the human eye, and any thing out of plum would be an eye sore to the visitor instead of an eye opener, or educator as we hoped. At last we got to the ribs, and we thought our worst troubles were over. But we found they had just begun. They were badly broken, and no cement we were familiar with, would hold them together. All the bones we must bore into, to hold our irons in place, were as hard as flint, it often takings three hours to bore a hole three-quarters of an inch deep. The ribs broken into many fragments, we found must have a hole into the end of each piece, a little rod of iron perhaps two inches, or an inch and a half long, must have their ends flared out, umbrella-like, to prevent coming out when the cement is set. We used a solution of 
gum Arabic, and made a paste as thick as cream with dental plaster. To prevent spoiling, we poisoned it with corrosive sublimate, and to prerent the cement from hardening too soon, we put into each rubber cup in which we mixed it a few drops of a thin solution of LaPage's glue. Please remember we did not have then, as now a fine press drill, the best manufactured, but a breast drill. One of us would often have to hold the rib, while the other bored a hole, and the time it took was trying to both. The boy who turns the grindstone had a pienic compared to us. If at mistake was made, too much force used, the rib would be broken, and fall to the floor and break again into a dozen pieces. So it became a byword with me, when we actually finished a rib, and lyad it fast in its place, "We are one rib nearer liome." We soon learned, that it was absolutely impossible to tell when a skeleton of this kind could be mounted. If we dropped a rib it might take a week to bore into the ends of the fragments and insert the small rods of battered iron, and cement them together. But patience will always win, no matter what the obstacle. At last our skeleton was mounted, but I notified Dr. Brock, the Director, and Mr. Lambe the Paleontologist too soon, forgetting the base had to be made of plaster. Just at the moment our plaster was hardening and we needed our wits about $11 \mathrm{~s}$, we ourselves were covered to the eyes with it, these gentlemen stepped down to view our mount. 
We were kept too busy to remember the plight we were in to entertain company. George took a picture of me, I here reproduce. Certainly I felt proud of that first open mount we ever made, and, as I say, the criticism that could be made, we hope to rectify if we ever have time. (Fig. 7.) 


\section{CHAPTER III.}

In the Eononton Beos of the Cretaceous

Having entered the Geological Survey of Canada, as Head Collector and Preparator of Vertebrate Fossils with the assistance of my two sons, Charlie and Levi, (George entered later), Westward we sped, and as even the longest journey will end, we reached Edgemont, South Dakota, and were driven to Charlie's ranch. My youngest son, Levi, and A. E. Easton, from Quinter, Kansas, joined us here. We drove in with our outfit on the 18th of July. A neighbor lrauling in to Edgemont the fine skull of Triceratops Charlie had prepared during the winter. This we shipped to Dr. Boule for the Natural History Mus. enm in Paris. It was a remarkably cold day for this time of the year and the mercury hung close to the freezing point. Loading team and outfit on the car and leaving it in charge of Mr. Eastman, we went on ahead. I took a sleeper on the night of the $19 \mathrm{th}$, and woke next morning in the foot hills of the Rocky Mountains-rugged indeed, showing snow in their darker recesses. Part of the day we passed through the Crow Indian Reserve, many of the Indians still living in tents. In the erening we reached Great Falls. I walked across the bridge here, of several spans or a thousand and fifty feet in length. 
The river is swift and full of falls and rapids. We passed through much country covered with the black alkaline shales of the marine Pierre beds. Some exposed sections are at least three hundreds feet thick, covered with a scanty growtl of short grass. We passed a large lake, miles in length, covered with wild ducks and other water fowls. No trees grew along the shore.

We crossed the International Line at Sweer: Grass and Coutts. Here we noticed a change; the country is a rich loam thickly covered with buffalo grass. We left Lethbridge on the 21st of July. This is a pretty town, with a beautiful park that promises to be a beauty spot some day in the near future. The country north is largely settled, I am told by farmers from the United States, and they are making the desert to blossom as the rose. We could see the Canadian Rockies looming up in the West.

At Calgary I stopped to have a row boat made and Charlie went on to Acme. Calgary is the metropolis of Alberta. I noticed many comfortable farm houses, fields of wheat, oats and flax, or herds of lıorses and cattle. On my way to Acme I saw plenty of hay on the open prairie. They speak of raising 120 bushels of oats to the acre and sixty bushels of wheat. Certainly $a$ farmer's paradise. Our car arrived at last after being eight days on the road. At Acme we got well acquainted with the pest of the north, for 
myriads of mosquitos made life a burden. We were obliged to wear nets while traveling and to keepasmoke going to protect ourselves and horses from their murderous attack when we made camp. We took the road between Rosebud and Knee Hill Creek to Drumheller, a small town at that time with a couple of stores. Ten days after leaving Wyoming we arrived in the valley of the Red Deer River, encamped three-quarters of a nile above Drumheller. On the 13th of July we found our first dinosaurian bone of a trachodon or duck-billed saurian. We soon bewan to find great numbers of loose bones piled np as jetsam and flotsan of the sea. They were first carried out, by river or lagoon, and at time of high tide were returned with dead seaweeds of the ocean to clog the shore. The best localities we found were above the river near the prairie lerel. They are ustally preserved in ironstone concretions, or a bog iron cover's the bones. They lie in sandstone that has a yellow streak through it.

The valley of the Red Deer River at Drumheller is a great chasm cut by the river four hundred feet deep into the heart of the prairie. Across from plain to plain it is nearly two miles. Tributary creeks and coulees have cut narrow trenches farther back into the plain while in the main valley, especially near the brink of the prairie, are long ridges, table-lands, buttes and knolls, pinnacles and towers down whose sides 
a rolling stone would bring up in a sudden halt in the waters of the river three or four hundred feet below. All this region, except of course the main channel and flood plain of the river, has been transformed by nature's sculpturing into fantastic bad-land scenery. The rocks carved into the most intricate patterns entirely devoid of vegetation, except perhaps, along the northern slope of some butte or rounded bluff where sponge moss and dwarf cedar and spruce with many flowers, found a resting place. The slopes are usually covered with cherty fragments that threaten to slip or roll under the feet and hurl the adventurous fossil hunter into the gorge below. The canyons are rich in coal, and now that the Canadian Northern Railway, has terminals at Calgary there is great demand for it.

The Edmonton beds are brackish water origin. On top is a great bed of oyster and clam shells. Below the principle bone-beds are about 200 feet of greyish clay (that crumbles under the feet), interlaid with dark shales and seams of coal. Many of the clay beds have hard iron concretions scattered through them. As these are practically indestructable they remain scattered over the surface, the other material having been carried away by water. There is a bed of massive sand. stone within a hundred feet of the top, and it weathers out into table lands. Below, the soft clays form conical mounds, often capped with 


\section{The Edmonton Beds}

grey sandstone that is fluted by weathering. The rain water becomes so thick with clay that it never settles but gradually eraporates into mud.

I was interested in the study of two problems: First, the environments of the duck-billed, horned and plated, and carniverous dinosaurs. Second, the story of how this river hats cut out of the heart of the prairies, this great canyon 400 feet deep and over a mile wide. I find in answer to the first question that the deposits were uniform through a great length of time, showing that the climatic conditions and the altitude were the same during the time the four hundred feet of strata were laid down. Further, in order to re. tain the same conditions the land subsided at the rate of deposition. The fine material of which they are composed, showed it to be ocean mud, and the mud, accumulated in lake or bayous, like the everglades of Florida. Swamps and bayous were the natural habitat of the duck-billed dinosaurs, while on the rising land were groves of redwood, sycamore, figs and other trees, with low heavily grassed plains covered with high grass horse tail, rushes, etc., through which wandered the lorned plated and carniverous dinosaurs. How often in my day dreams some stately dinosaur has passed before my mental vision: The forests, the rivers, the lakes and oceans of those ancient days have appeared in imagination as though they actually existed. So I ask the reader to put on my glasses: 
A low country but little above sea level, great flats near the sea covered with high swamp grass, rushes and moss, through which meander slug. gish streams, lagoons, and bayous, often widening out into lakes of considerable size, all receiving the high and low tides of the near by ocean. On the rising land the giant redwoods cast their shadows across the silent streams. They grow in fairy circles with the parent tree in the center often, or in case she has dropped out, a hollow circle is formed. Palms, sycamores, figs, masnolias and many other trees that now adorn our forests thrived along the Cretaceous everglades. Such an environment was the home of the ancient dinosaurs. They were the rulers of land and water. There were many soft-shelled turtles in the streams, as well as countless gar pike and stur. geon. The scene was a vast panorama of beauty. The sheen of the water, the salt-meadows of lising green, the dark forests moaning in the back ground, and over all, the sun revolving on its western course. Perhaps oul imagination has carried us back to a bayou of the Edmonton Cretaceous. Yes! See yonder the foam ripple off the huge back and tail of a swimming reptile, a duck-billed dinosaur or trachodont! He is rapidly approaching a specially seductive patch of horse tail rushes just across the bayou from us. The enormous head, over three feet in lengtl, swings gracefully on a long delicate curved neck, his front limbs, six feet long, and hind ones eight. 
The front foot is elegantly proportioned and a strong web stretches across the four fingers. The hind limbs are pillar-like and terminate in three great hoofs with coarse web between the three great toes to assist in swimming, and to prevent sinking deeply into the mud of the bayou when he stopped to feed. The great trumk, projecting half way above the water, and the enormous tail over fifteen feet long. This tail he uses with great effect to hurry him to his pasture ground. It dashes the water into foam as we have already seen. The whole body is covered with a thin skin in which are arranged like mosaic-work small polygonal scales or small tubercles, ornamented with larger scales arranged in rosettes. The whole in paralell rows glowing pattern blends harmoniously with the reeds and rushes near the shore. See how the patches of foam rise high in the air, tinted by the sun's rays so they show the colors of the rainbow. Now he passes us at full speed like a racing yacht and comes to a sudden halt, by planting his powerful hind feet in the muddy bottom. The toes spread out covering a square yard of mud. With his front limbs converted into arms, he draws into his huge mouth, large mouthfuls of the luscious forage to be sheared into shreds by his scissor-like teeth behind, after it has been nipped off by the hard horny duck-bill in front.

There are three rows of teeth in the cutting surface and magazines helow, containing two 
thousand teeth in all. As fast as one tooth is worn out it is shed and anotler takes its place. livether, they are so arranged that only alternate teeth can drop out at a time. Professor Marsh has callod this giant lizard Trarhodon annectens. We have certainly a fine view of him. Back of the hearl a frill rises gently to the shoulders. The sun light reflects from the water every shining scale and contour of the graceful body, and exhibits the play of the strong muscles. He is in his natural habitat and has finished breakfast, if you please. Lifting his head he turns towards the narrow neck of land that separates him from a bayou just beyond. He wades through the mass of rank vegetation towards shore, and as he, reaches the muddy slope between high and low tide, he rests his front feet on the sloping bank. Then with body raised a few feet above the mud, and dragging his tail behind him when he reaches the fringe of bushes, he pushes his duck-bill into them nosing around as if to scent some danger. As the coast seems clear he hurries across the narrow strip of land.

The cooling touch of morning breeze

Waft incense from a censor hidden

The gentle sighing of trees

Add music to the scene unbidden.

As he hies himself away "to fresh scenes anil pastures green." But hark! a noise that thrills us, what can mean it? See! It is the tiger of the Everglades rushing forward toward his prey. 
His two powerful limbs on which his body is posed are full ten feet in length. The three toes armed with claws of hardened horn are over ten inches long. He spans full thirty feet in length. Small front limbs are hardly noticeable. He drags a long tail on the ground. His long and powerful jaws are armed with horrid teeth. Some six inches in length with double edges serrated on their cutting surfaces. Our herbivore. knowing his weakness, rushes frantically back towards the water, but he is muable to reach it. His enemy is upon him and with relentless fury strikes blows at his unprotected body, with firsi one, and then the other claw-armed hind foot that tears open the tender fresh and pours a flood of life blood on the ground. The awful terror of the scene has rendered us speechless with horrol, coming so swiftly in the peaceful ledwood forest. The sun was not darkened, the perfume of flowers still scented the air; the genthe breeze sighed in the branches over head. Though the victim was a cold blooded reptile, we had become deeply interested in him and we were unprepared for such a woodland tragedy.

Coming back to the second question that has so interested me: How has this great canyon been cut out of the heart of the prairie through the rocks of the Edmonton rretaceous?

The recession of the cliffs of the main canyon and its side coulees is very rapid. The upper beds, composed of uncemented fine sand and 
clay, under the action of rain, or frost, cave off in great avalanches of shaken up material that rapidly dsintegrate and is carried off by the rains to the Red Deer River, where the high water hurries it on to augment the sediment arcumulated by the lake or river's mouth or Lake Winnipeg itself.

Often acres of the margin of the prairies slide down and fill a coulee, or drop into the river, through which a passage is rapidly cut and the: mass is shoved on by other masses behind, until it has all been carried away. Every time it rains the fine rlay and sand dissolves like soft soap, and as mud is carried into the river. The deeper canyons have their ridges bisected by lateral ravines until they meet and form buttes and knolls that in turn weather into hay-stacks or sugar-loaf mounds that are being constantly reduced by wind and rain. and frost, until now, often we find a perfect labyrinth of intricate gorges, buttes, towers, and table-lands of every conceivable form, strewn, with traveled boulders, from the prairie above, or masses of bog iron that have withstood the disintegrating action of the elements. But for this constant corroding of the rocks and the consequent recession of cliffs, we would know nothing of the wealth of extinct forms that lie here in their last sleep. Nothing of the fauna and flora of the day when these dry bones were full of life and vigor, when the marshes and lowlands echoed to the formida- 
ble tread of reptiles, and the crush of mighty carnivores rushing relentlessly on their prey.

In addition to boulders, and iron concretions, the faces of the bluffs are covered with cherty chips that accumulate often in some shallow wash. These slip under the feet, and made it difficult to climb the steeper ascents. More than once I measured my full length on the steep surface cutting face and hands by the impact. But strange to say when it was wet, and the clay beds were as treacherous as if covered with soft soap, where ever the cherty fragments arcumulated, one could climb on them in safety, as they were pressed into the slick clay, and held the feet securely as if there were spikes in the shoes. On account of these fragments I was able to travel orer the beds on a wet day, and found the best deposit we discorered of fossil bones, in the coulee through which the Canadian Northern has its right of way, on the west side of the Red Deer River. Te made a large collection of scattered bones here.

Near here, also, we secured a great collection of redwood leaves, and branches with their narrow leaflets as heantifully preserved in the flinty rock as if impressed in wax, but yesterday. The Red Letter Day for us, however, was when Charlie found on the 13th of August, 1912, the wonderfully complete skeleton of a duck-billed dinosaur, the first ever mounted in Canada. It is thirty-two feet long. The end of the tibia only 
was exposed, within a hundred yards of the shack of Dan. Mr.Gee, forty yards above the forks of McCheche Creek, six miles west of Drumheller. The entire skeleton except the tail was present Lying on its right side, the hind limbs were doulled on themselves, the front ones at right angles to the body, and the head bent towards the front limbs. We got the skeleton uncovered and discovered the ribs were expanded and in natural position. The animal lay like a dead dog; I thought I had nerer seen any thing so pitiful, and forlorn.

Charlie and I, mounted it the next winter, and were careful to put a little life in the dear! skeleton by straightening out the neck a little, and giving a sense of motion as it were to the tail so that the animal would not look as repulsive as it otherwise would to some observers: for there is such a thing as breathing life into the skeletons that have been buried out of sight these three million years or more. We have mounted it then with the slight changes in the neck, and, and one hind limb that otherwise would have covered important bones in the original matrix, and in the position in which it was floated to bank, and was covered up with mud. Even the skin impression is preserved along the pelvis; and the rows of ossified tendons that cross each other in three rows, like basket work, showing they were used to bind the muscles of the 
back and tail together. They were likely flexible as whale-bone in life.

The figure $S$ shows the skeleton as now mounted in the Victora Memorial Museum, of Ottawa, Ontario. It was no easy undertaking to save and mount this wonderfully complete skeleton; it was buried in fine sandy clay that was cracked in all directions, as were the bones, checked into thousands of fragments. Only our years of experience in the field, and my faith in the skill and patience of Charlie gave me courage to believe that it could ever be mounted. It could never have been saved, but for knowledge of the plaster process of collecting.

I will try and give ny readers the process by which we not only kept the bones (broken into countless fragments and ready to fall into pow. (der), in their places, but saved the shattered matrix in which they were emberded. My whole party worked in what I call for a better term "a quarry." The first thing to do was to remoie with pick and shovel the loose sand and clay and lay bare a floor in the cliff large enough so we would have plenty of elbow room, and could work down around the skeleton. We first traced the latteral spines so there was no danger of digging into the bones from above. This work was done with a digger and crooked awl, aud only the merest trace of the bones were developed; when bones were exposed, they were instantly filled with shellac. They fall to powder on ex- 
posure without this precaution. The dorsal spines were traced in the same way and the ribs in front. Then we cut down several feet outside the skeleton so we could get under it. The skuli was covered with burlap soaked in plaster and removed. The front limbs came next; and here we learned a lesson that was of inestimable value to us in taking up the vast bulk of the trunk region. When we turned the front limbs over a lot of shattered rock fell out and threatened to bring the bones with it and thus ruin the bones. No human being would have been able to mend these bones if they were once jumbled together, so we thanked God, and resolved not to attempt the big sections without covering the entirs trunk beneath as well as above with plaster and burlap to hold the rock in place, and, of course, the broken bones. A surgical operation, in fact, in which the broken joints are kept in place 111 til they reach the skilled preparator in the $\mathrm{Mu}$ seum laboratory. We dug a rery narrow trench under the skeleton, after the upper surface had been heavily covered with plaster and burlap, and willow poles to hold it firmly together, dividing the trunk into two sections. Each weished about 3,000 pounds. After our trench had been dug we found that the plastered strips would not stick and pulled part of the rotten rock off with them, and threatened to allow the bones to fall out too. Our only plan under the circumstances was to stick the ends of our burlap strips securely 


\section{The Edmonton Beds}

to either side of the skeleton, above and when we had a number of them firmly attached we threw loose dirt under them and tamped it firmly thus forcing the plaster strips in place until they hardened or set and held the loose rock and bones. Then we built supports under the hardened strips, and continued the process until the whole section was held firmly together. It was separated at the dividing line by leaving one section untouched and firmly bedded in its native rock. We then cut a narrow channel to the bones, above and below, and by removing the supports broke off the sections tirlough the bones. The other section was prepared in the same way, the ends were covered, and our skeleton was ready for transportation.

When we threw out the earth from above and around the specimen we built a platform so we could hack a wagon up to it. Dan McGee who had handled hears logs in the eastern woods built a runway of two inch planks to the wagon. Then the boys, under Charlie's management started to load a heavy section, Dan with bar sunk deeply in the earth to act as a snubbing post, a strong rope around the section and one end in a half hitch around the bar. They edged the mass towards the slide. What was their surprise, when the section started in obedience to the law of gravity, to see the crow bar torn from Dan's hands and thrown to one side, and the section unrestrained gaining momentum at an amaz- 
ing rate. The men below who wele guiding it sprang out of the way, and the huge mass never stopped until it landed in the bottom of the wagon. The careful wrapping had prevented any damage, and without doubt it would have rolled to the bottom of the ravine without hurt. I must acknowledge that I was very doubtful whether it would be possible ever to nend the broken front limbs. They had been near the surface, and hard been subject to the effects of frost, and plauts, their rootlets had severed the broken fragments, and fed on their edges destroying often the contact faces. But Charlie's patience and endurance settled the question. And after six weeks of constant effort he had filled the bones with shellar, picked up the fragments with small tweezers cemented them, and pressed them into place. No one without close inspection could tell that the: front limbs had ever been broken. The tail I pestored from scattered bones picked up in line bone beds, building it up by comparison with the one I sent to Paris, rather an enlarged photcgraph of the specimen made by the division of Photograply of the Geological Surrex.

Levi found a second specimeu, larger than Charlie's in the Edmonton, near Wigmore Ferry, a few miles west of Munson. This we have not yet prepared. So we returned to Ottawa after three months lunt for big game in the Edmonton rocks at Drumheller, Alberta, with a carload of fossils. 


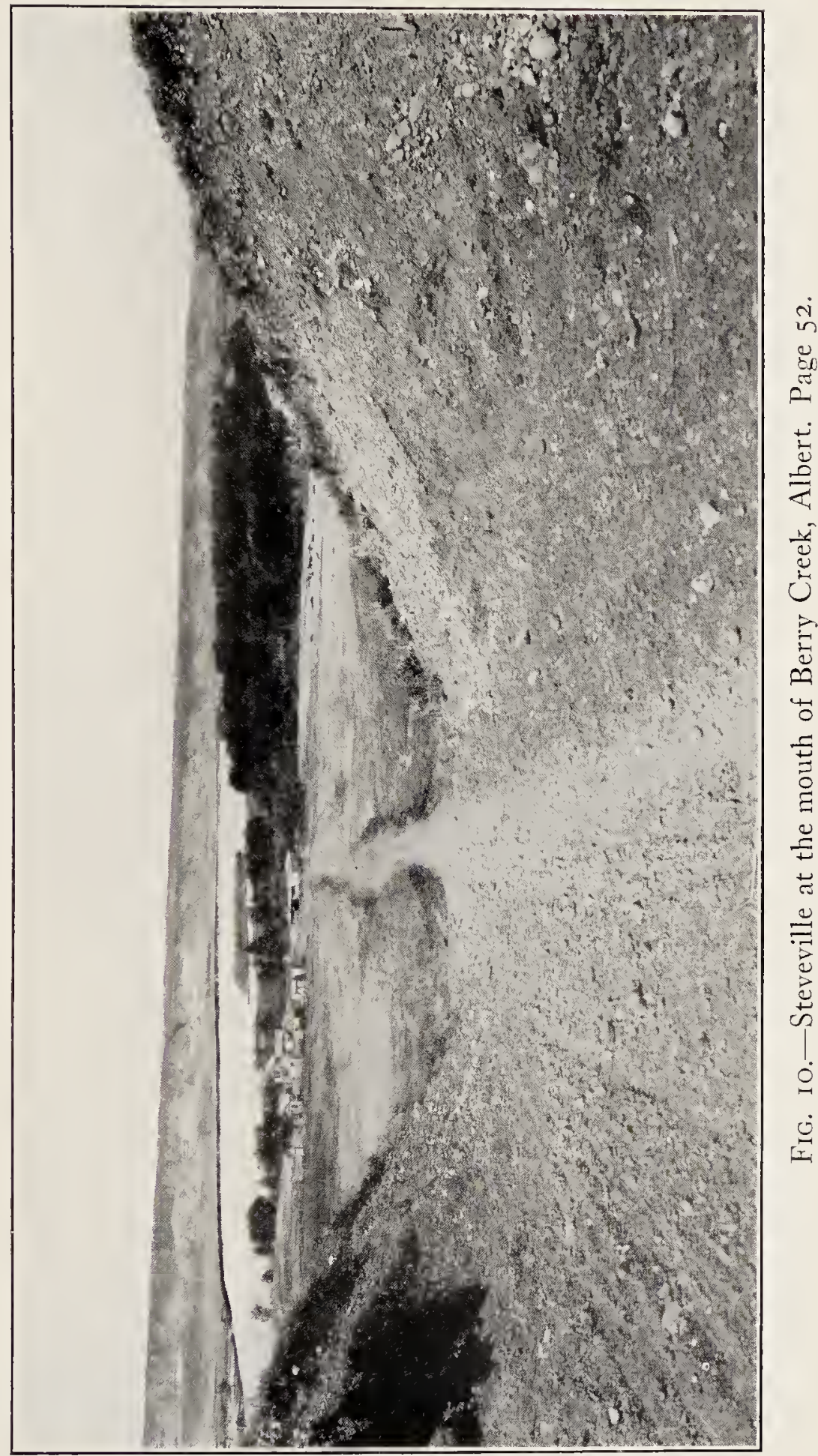




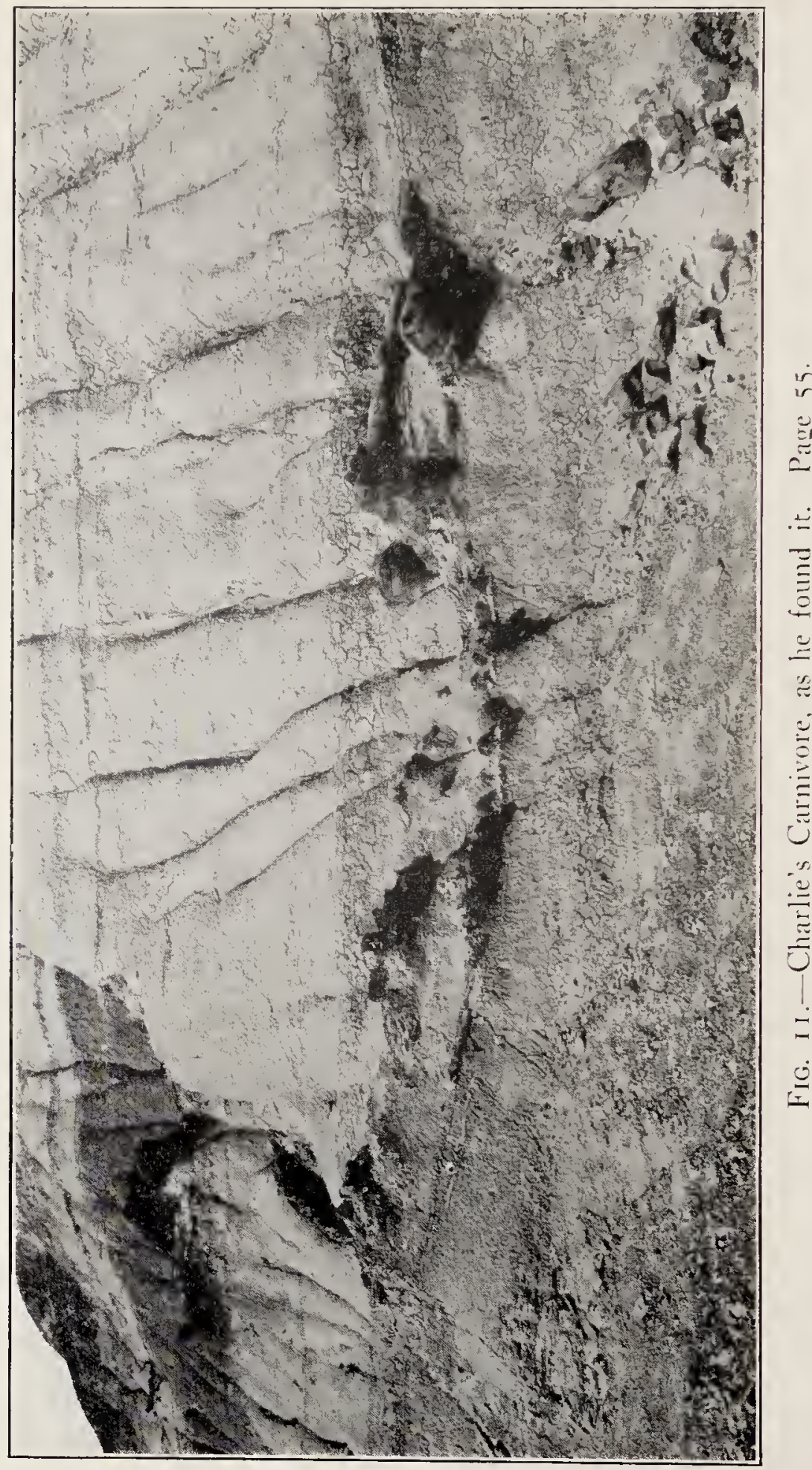




\section{CHAPTER IV}

WE WXPLORE DEAD LODGE CANYON

We reached Drumheller, where we purchased from Mr. Moore of the same place a five-horse power motor boat; we also built a flat boat 12 feet by $2 S$ feet. We pitched two tents on deck, one for sleeping in, the other for a kitchen. Jack McGee and I went aboard. We threw a rope to Charlie in his motor boat, which he fastened to a post on the small deck behind. Some kindly hand pushed us off into the stream, Charlie got up power and dragged us into the current. The women and children were on hand to see us off. Our motor boat under Charlie's management went chug, chug, down the river at the rate of five miles an hour. The water was at full flood. covered with drift wood and floating logs, but we rapidly passed them. Levi had taken the team and wagon over the rough road to Steveville. As we swiftly glided along, the table buttes, haystack-like nounds, and long naked ridges that mark out the exposures of the Edmonton Series, were in full view on either side. The heads of ravines, under the prairie level were packed with clumps of aspen and other trees, as was the narrow flood plain and scattered islands 


\section{We Explore Dead Lodge Canyon}

with cottonwoods. We reached the mouth of Willow Creek at one thirty in the afternoon. The scenery in ever-shifting panoramas, was beautiful indeed. The rushing river hurried us on from one prospect to another, each one seemingly more beautiful than the last. The grey sandstone beds increased in thickness, and the visible, coal seams thinned out. Fifteen miles below Drumheller the Edmonton beds ran under the river, the yellow silt of the Pleistocene capping the older beds. Great land slides impinged or the curves of the ox-bows of the winding stream. Concretions stuck out of the sandstone ledges, like toad stools on a pine $\log$. The river was about 600 feet wide. At three in the afternoon the upper buttes had disappeared. Sharply rounded haystack buttes, or sugar loaves, and narrow ridges that tongued out from the prairie on the south, were visible. On the north, long giassy slopes were frequent. The valley widened and the hills retreated towards the distant prairie. There were ranches along the flood plain. At four thirty we reached a ranch twenty-five miles below Drumheller. We now got into the marine Fort Pierre. These beds underlie the Edmonton, and were exposed along the river's edge. Rounded bluffs, with here and there an exposure of dark shales were the order of the day. The timber shrunk and the grass was short; showing the effects of the unfriendly alkaline shales on the soil. By five o'clock we had left 
the last of the Edmonton beds behind. The Pierre and Pleistocene occupy all the country. The flood plain widens to about three miles. We tied up for the night at a willow thicket, and the tireless chug, chug, of the motor ceased. We prepared to spend the night there. After supper I went into the Pierre hills, and found numberlesw large concretions that contained huge am. monites. But just as the rock was shattered by the weather so also were the shells. I could not find a good specimen. We got a number of beautiful ones, however, over the Belly river beds, where the Pierre again appears, showing that before, as well as after, the country was occupied with the fresh water beds of the Cretaceous the sea had covered the country for a long period of time. We were early astir, and Charlie hauled us in mid-stream. A strong east wind blew in our faces, it was disagreeable, because we had to lower our tents to the deck, as they acted as sails, and the power of the wind on them was stronger than the current and the five horse power motor: would have driven us up stream. The choppy waves beat constantly against the front and sides of our scow curling over the deck itself. The wind howled in the few cottonwoods along the shore and on the islands, that we passed. The hills on either side were lower; at Bull Pond Creek, scarcely seventy-five feet in height. About nine o'clock we reached the fifth ferry below Drumheller. The ferry man had stretched a 


\section{We Expore Dead Lodge Canyon}

barbe? wire across the river; Charlie saw it as he drove his motor under it and shouted to us, Jack rushed for the rear guiding oar and $I$ for the front one, they were both stuck several feet up in the air, and if the wire harl caught one, it would have swamped us. Jack had his back to the wirc: and when he released the oar and stood up, it caught his hat and threw it in the river. If the wire had been six inches lower, or the river six inches higher, it would have cut his head off as easily, and thrown it into the river.

We were also thankful the tents were dowu. If they had not been, they would have been toru from the deck. We soon got into a new horizon. I knew this by the change in the sculpturing of the bluffs. We tied up to a willow thicket for dinner; the wind began to fall. At ten minutes of five in the afternoon the naked buttes, towers and ridges of the Belly River Series of the Cretaceous loomed up in the distance. We soon reached Steveville, (Fig. 10) and managed to make a landing in the swift stream, just below the Ferry, and below the mouth of Berry Creek on whose border the little town stood. A lospitable town it proved to us; especially have we often enjoyed the hospitality of Steve Hall's Hotel; after this jolly good fellow the town gets its name. We were not far from Mr. Brown's camp. He had a party here collecting for the American Museum. I was delighted to learn that my son Geol'ge, who had been working for the American 


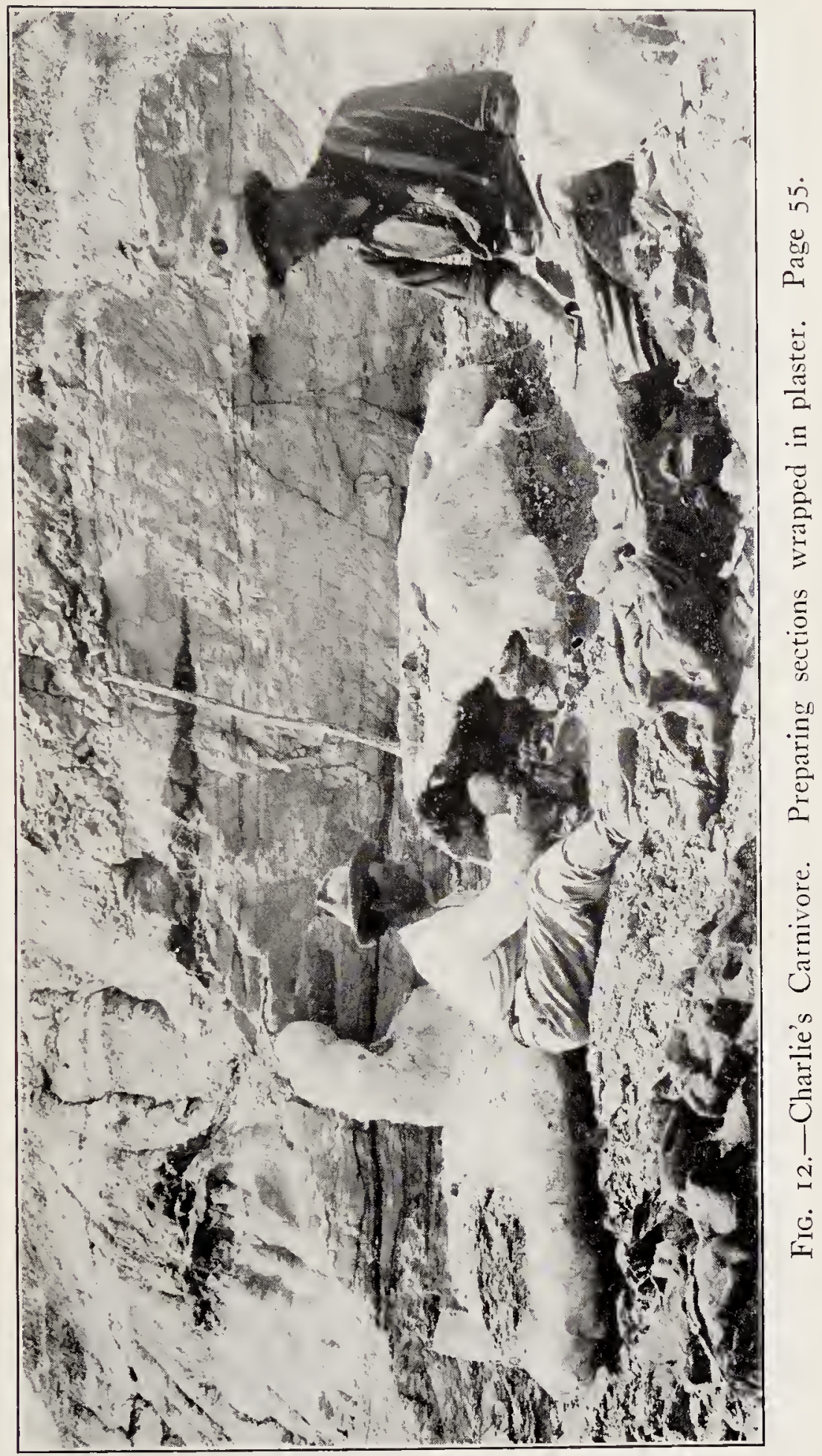




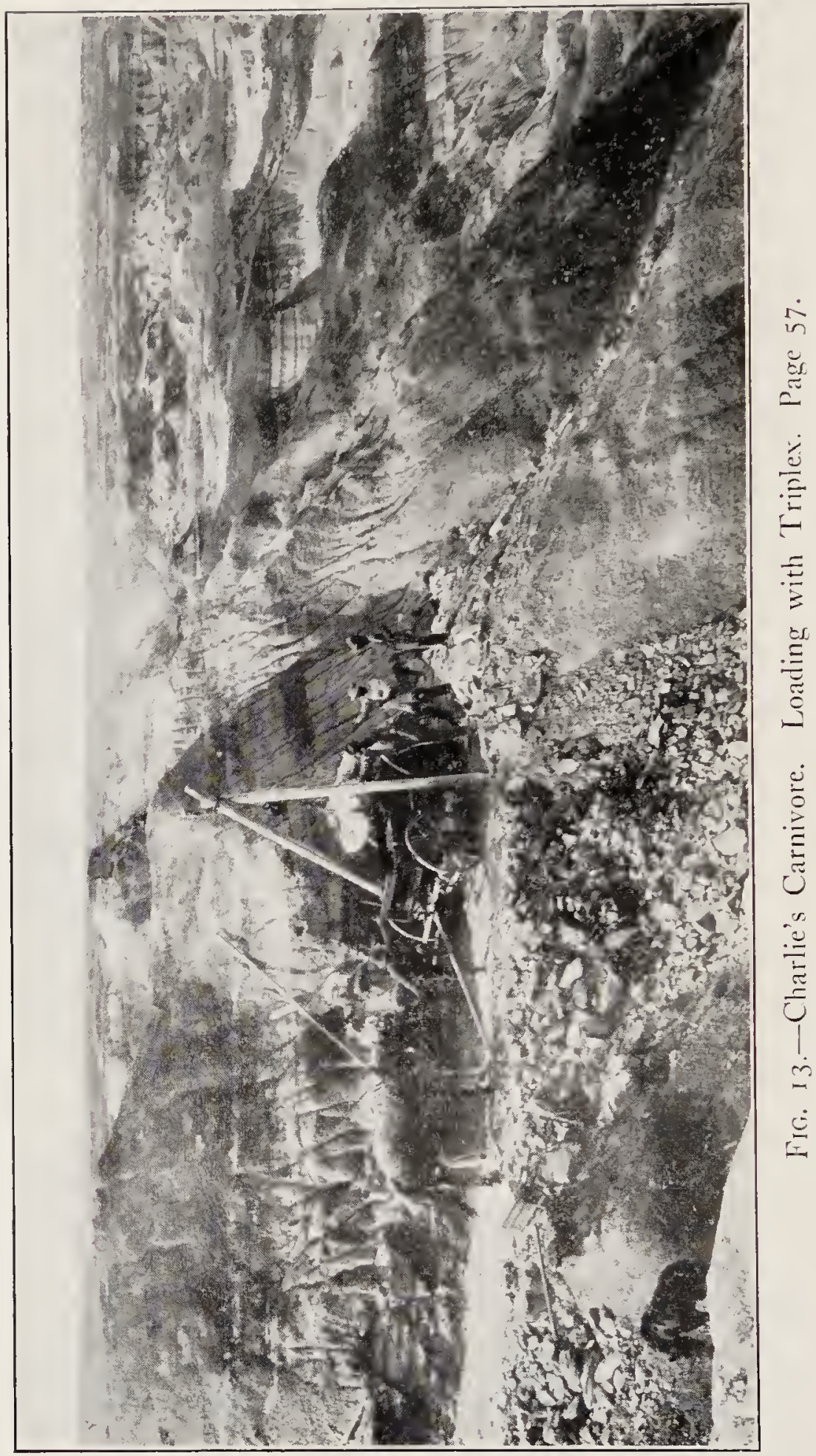


Museum under Brown for over a year, had been appointed on the Geological Survey of Canada, and would join my party.

We found that we had made the eighty miles from Drumheller in sixteen hours (Fig. 10) travel. And though the trip had been delightful, and exciting, I was glad to walk again on solid ground. I had gotten used, however, to the cheerful chug, chug of the little motor, saying "all's well." It took good judgment on Charlie's part to choose always the deep water route, on a stream he had never navigated before, to know which side of an island to take when the current parted, and always choose the strongest. Mr. Shaw the ferryman at Steveville, showed me a ledge of rock at the water-level, about a hundred yards above the ferry, that was literally packed with plants, especially water lilly leaves, that were as perfectly preserved as if impressions were made of them in wax. I secured a large collection for the Victoria Memorial Museum. Charlie and I went down the river to spy out the land. We found a large exposure of the strata on the south side of the river. He was so fortu. nate as to find the skeleton of a carnivore that promised to be the most perfect one known to science at that time, from the Cretaceous (Fig. 11). This has since been proved to be the truth. In this specimen the ventral ribs and one frosit limb appear in their normal position for the tirst time in a carniverous dinosaur from the Cre- 


\section{We Explore Dead Lodge Canyon}

taceous. The figure shows it as he found it. The double row of ventral ribs, the head and the hind limbs, with one foot lying on the slope in sigit. Our work was thus laid out for us and on the Fourth of July we moved our camp to the site shown in the figure, about three niles below Steve ville on the southern side of Red Deer River. Our camp was near a large area of badlands. A splendid flat for the horses, wood and water without end. If you will reread my explorations of the Kansas Chalk, where we had cow chips io burn, and alkakine water to drink, beneath a burning sun, you will realize how much we anjoyed this camp. (Fig. 15.) It was not perfect, bowever, the mosquitoes made life a burden, but with smudges ever going, our nets over our shoulders when we moved in the sage brush, we were reasonably comfortable, especially as we got fresh butter, eggs and chickens every week from a neighboring farmer. This proved the richest camp I ever made. Further, to add to our blessings we were only three miles from the post office, and a trip for the mail on our motor boat, was a delightful change from the heavy work in the beds. Levi came into camp with the outfit and George soon joined us, and no one ever had so many born fossil hunters in one party before, full of enthusiasm, each trying to find better specimens than the other, but with friendly rivalry; we put in the most profitable and delightful summer I 
have ever experienced. Charlie took possession of Jack McGee and settled down to the heavy work of excavating the carnivore, from the face of the cliff. I show you a picture (Fig. 12) taken by Charlie himself of the two men at work, after they had nearly finished wrapping the two heavy sections of the trunk; Jack is cutting burlap strips, while Charlie is mending some bones that tore out when they separated the two sections. Then again (Fig. 13) with triplex block they are hoisting a section into the wagon. The two men put in six strenuous weeks, removing the gxeat mass of rock that lay above the bones, blasting out tons of rock, and dumping it below on the side of the gulch to make a road. Jack used to say in regard to the skeleton "it is altogether wonderful." To which sentiment I fully agreed. You will get some idea of the labor required if rou look at the picture with Charlie standing in the quarry after the specimen had been removed. (Fig. 14.) When they hauled the sections out it was along a ridge so narrow that if the horses had balked or a wheel had siipped they would have been dashed to pieces in the: gorge below. So important seemed this specimen to me I wanted the advise of the principle paleontologists in the Eastern United States, before we mounted it. So with authority from the Director of the Survey, Charlie and I visited Pittsburgh first, where we were cordially received hy Dr. Holland, the Director. Both Dr. Hol- 
land and $\mathrm{Mr}$. Peterson the paleontologist and also Mr. Earl Jouglass, the noted collector and preparator of the huge Brontosuurus materal from Nevada. All three agreed, that in their opinion we should make a panel mount of the carnivore, not taking it out of the original mat. rix. They used the argument that a student could then come to his own conclusions in regard to it as easily as if he had collected it himself, while if we made an open mount of it, he would have to depend on the veracity of the preparator. We were kindly treated here and saw the magnificent Brontosaur Mr. Douglas had found in Nevada. It is a fourth larger than the famous Diplodocus carnegii. WVor1d renowned, because of the casts Mr. Carnegie lias sent to the Museums of Europe. The Brontosaur is sixteen feet high at the hips and eighty-two feet long. We hurried on to Washington, and there both Mr. Gilmour and Gidley, the vertebrae paleontologists, were warm in their opinions that it would be a crime to take it out of its original matrix, and thus lose the authority that goes with it. Mr. Gilmour showed me the fine skeleton of a Slegosaur they had just mounted in the way he proposed we should mount ours. It lies on a base a couple of feet above the floor, in the rock in which it was buried. He assured me that people showed more interest in this mount than in any other in the National-Museum though they had some splendid open mounts. Mr. Gilmour claims that 


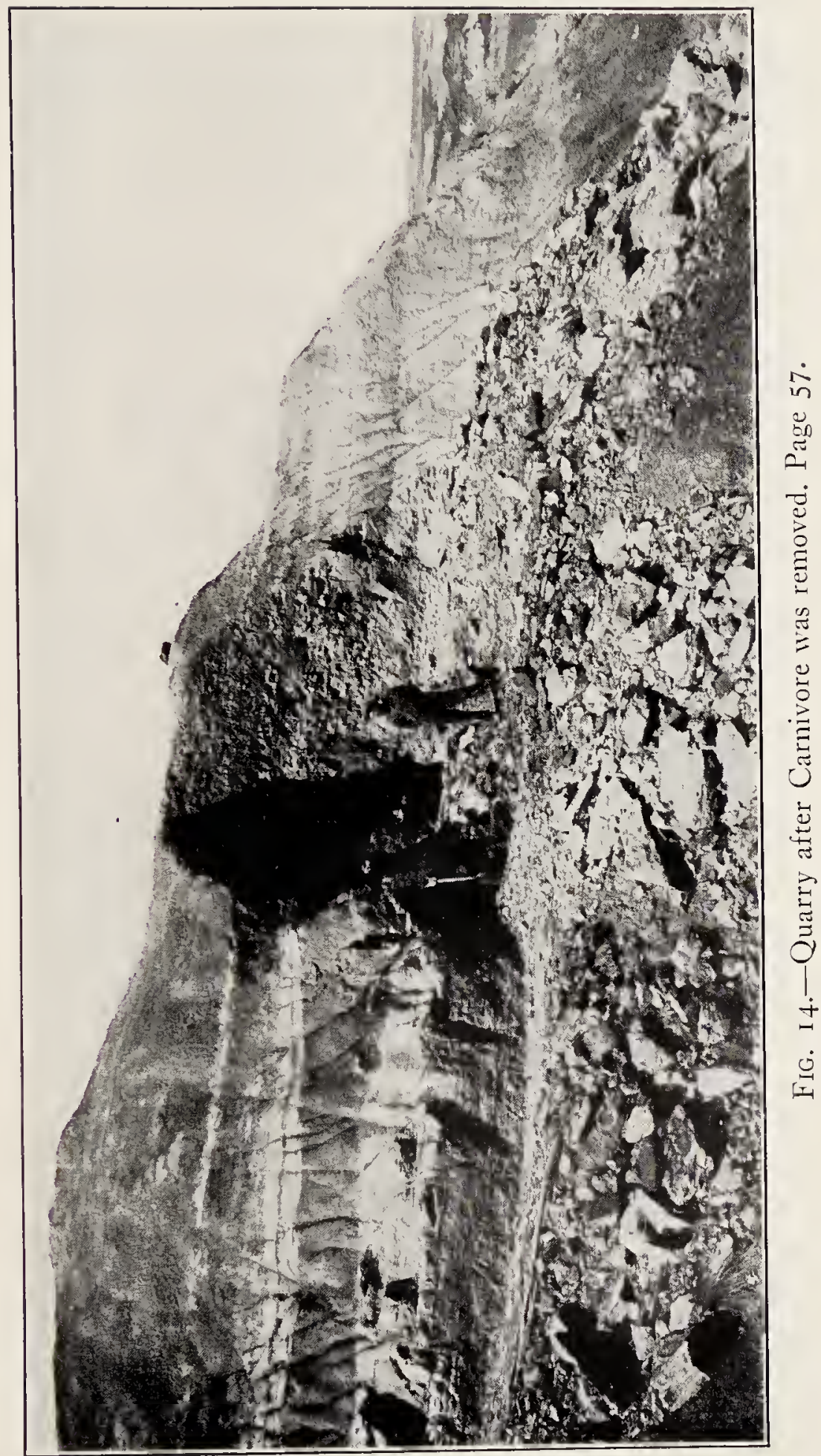




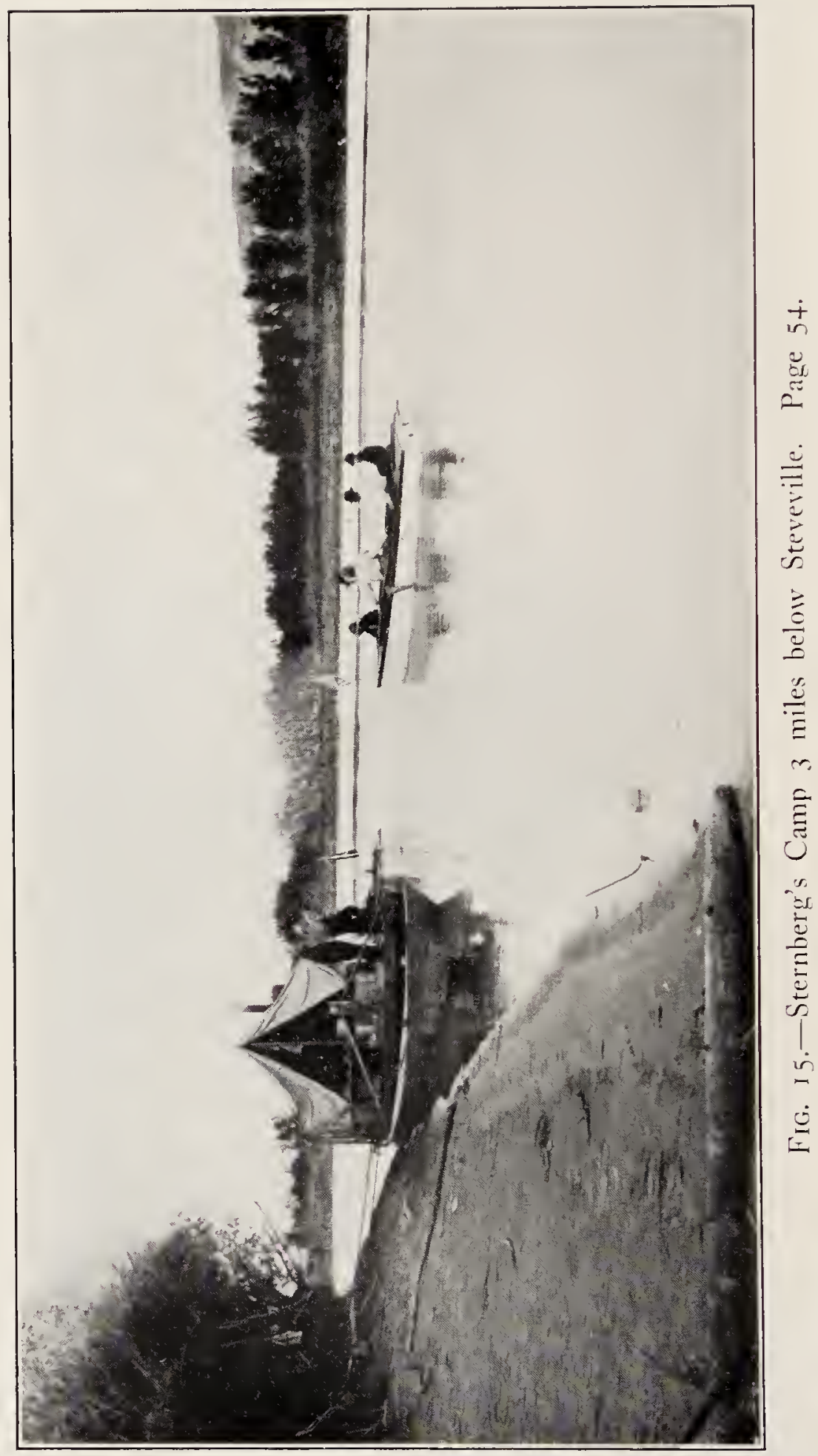


to advance our science rapidly, complete articuiated skeletons, should bo left in the original rock in which they were buried. The scattered skeletons and those well known might be exhibited in open mounts.

At Philadelphia, I sal Dr. Nolan who has been the Secretary of the Philadelphia Academy of Science since he was first elected in 1876 . He thought a slab mount the most impressive, and could not realie how any one would think of mounting it otherwise. Then we traveled out to Princeton, and this was the first and only time I have been there. I greatly enjoyed their magnificent collection. I was especially interested in Waterhouse Hawkins paintings on the ceilings, of troops of Laclaps, or duck-billed dinosaur's running on theil powerful hind limbs, carrying their luge tails clear of the ground-a pose that many paleontological artists stick to with amazing tenacity. I have proved over and over again that these animals were swimmers. We were invited to the home of Prof. W. B. Scott, and after I told him the condition of our carnivore, he at once said the bones should not be taken out of the matrix. He instanced the case of the great collection of Iguanodonts in the Brussels Museum, some thirty individuals. Many mounted in their rocky sepulchers. Our carnivore should lie as we found him on a slabe in bold relief. I must confess that my original idea that it should be mounted over the partial skeleton of a Tracho- 


\section{We Explore Dead Lodge Canyon}

dont on which he was to be feeding was fast falling away from me in the face of such opinions by the greatest of our paleontologists. When we reached New York we met in the American Museum, the President, Dr. Henry F. Osborn, Dr. Mathews the Curator of Vertebrate Fossils. and his assistants, Mr. Granger and Barnum Brown. Dr. Osborn gave the opinion that was held by all the others, that we should mount it as we found it, clearing away the rock so all the bones stand out from their matrix, but held in it, except where limb-bones might corer some other bones; in which case they must be removed and mounted clear. I had not a foot to stand on, when I visited the authority on dinosaurs, Dr. Lull of Yale. He took us out to lunch and agreed with the other students, without question. I was glad indeed, therefore to reconsider my first opinion and recommend to the Director of the Geological Survey, that we should mount it as the paleontologists liad indicated, as I believe this would be a world specimen in which all str. dents of ancient life would be interested. Mr. Lambe agreeing with this opinion also.

Charlie spent the greater part of eight months, including the winter of 1913 , in preparing it. There is a great deal more to do before it is finally mounted permanently in the Museum at ottawa. Mr. Lambe, the Vertebrate Palentologist of the Geological Survey of Canada, has called this noted specimen Gorgosaurus libratus, or in 
English, if you please, "The fierce looking easily balanced carniverous dinosanr." The skull is about three feet long, with all the teeth in place; they are from four to five inches in leugth, slightly recurved, with flattened sides, double edged, with serrated margins. Fierce indeed must he have looked, wheu he slunk up on his prey, his eyes flashing cruelty, with glistening teeth also, and forked tongue. His entire body from the front of the jaws, to end of the tail was twenty. nine feet in leugth. His powerful hind limbs, on which the eutire body was balaucerl, were teu and a half feet in length. He had three great, claw-armed toes, and one not so large, raised from the ground like the spur of a rooster. His front limbs were mere restigials, only twentythree inches long; and the digits were reduced to two, with weak claw bones. We are unable to imagine to what use they could have been put. The abdominal walls were protected in front by 16 pairs of ventral ribs, that were united to the regular ribs by rods of bone on each side; they passed each other mid-way in front, in order to allow the increase and decrease in the walls during the act of breathing, sliding at their ends, back and forth with each breath. They were as effectively protected as if sheathed in iron hoops. The long bones were hollow, and the feet like those of a running bird. In front of the pelvic arch the pubic bones were provided with two large feet, that, in position, were in a line witl 
the ventral ribs. In order to rest on these he inust have been able to flex his limbs like a living Sphenodon, or New Zealand lizard (eighteen inches or more in length) does. This seems a more reasonable pose to me than the one usually given Cretaceous carniverous dinosaurs. I can. not believe he always made a conspicuous object of himself when he was hunting over the grassy and rushy plains for his prey, the herbiverous dinosaurs. I would rather think he slunk along their spoor or the trails, they had beaten through the rank vegetation, as a tiger would crawl up on his victim. So I picture him, when I try to put life into his old dry bones. It has been the habit of paleontologists to make a composite animal of a dinosaur, with characters of birds, mammals and reptiles. Sevelal trachodonts and horned dinosaurs I have seen painted, with a thick rhinoceros-like skin, when we now know they had scales patterned after the Gila Monster of Arizona today as far as the scales go. The bones on the underside of the tail, called chevrons, are shaped like runners, as if to carry cout my belief, that he dragged his tail behind him like a lizard of today. What was his rentral armor for, if not to protect the vital organs from the hard tough rushes and swamp grass of his habitat? What would be the use of the ventral ribs otherwise? From my work in shop and quarry, I am convinced these great reptiles will be treated and posed as lizards some day. Now 


\section{We Explore Dead Lodge Canyon}

the Vertebrate Paleontologists follow Cope, and Marsh in their views of these animals when, in reality they are simply reptiles that have long since become extinct, leaving no living representatives. The nearest being the lizards.

I climbed the rugged buttes and ridges. Many are entirely devoid of vegetation. Our work was in a canyon four or five hundred feet deep and measuring a mile from prairie to prairie, with long ereeks or coulees running back into the flats. Their head branches spreading out like an open fan, as on Sand Creek, exposing thousands of acres of denuded rock to the sun. I was so fortunate as to find two more or less complete skeletons of a new duck-billed dinosaur, one with much of the beautiful skin impression preserved. The small scales, often mere tubercles, polygonal in shape arranged like mosaic-work in a pavement with ornamental elevations "limpet-like" in form, they are arranged in paralell rows along the abdominal walls and were reduced in size and number in the tail. Mr. Lambe has figured some of these lovely scales. He calls the new creature Stephanosaurus, marginatus * or the crowned lizard. Barnum Brown discovered a wonderfully complete skeleton here, he gives it the name of Corythosaurus casuarius. Because the crested head resembles a Cassowary. I am delighted to be able to use with the permission of The American Museum authorities Deckert's re-

* The Ottawa Naturalist, January, 1914. 


\section{We Explore Dead Lodge Canyon}

storation for my Front Piece. With all the wonderfully complete skeletons my party have found of Cretaceons dinosaurs, I am forced in this specimen, to yield the palm to Mr. Brown, I am glad to acknowledge the wonderful skill of this indefatigable Collector and Paleontologist. Science can never repay what she owes him for grand skeletons of the Cretaceous Dinosaurs with which he has enriched the American Museum. Half a mile away from the skin impression and some of the skeleton, I found part of the head, and many of the bones, including the ischia: or the two pelvic bones that point backward and the further ends of these bones were footed, showing that he could bring his huge body down to the ground and rest it partly on these strong feet. Unfortunately only half of the head was present and its top was not complete. However, enough was preserved to show these saurians with footed ischia had crested heads, and were different in this respect from the Trachodon already referred to from the Edmonton Formation. I was so fortunate as to find in the same beds at Loveland Ferry, ten miles below the mouth of Dead Lodge Canyon, (a new locality Charlie locted in 1915) two skeletons, within fifteen feet of each other, one with most of the tail, the trunk to shoulder blades, and the hind limbs. The other contains three caudal, or tail vertebrae, and the whole column in front, with arches, front and hind limbs, except that one hind foot and 
one fore foot were missing. A very fine head was found pressed back against the back bone, showing that the animal had died in the water, when the gases raised it to the surface and the pressure of so large a body against the head, forced it back. When the gases were liberated the body settled in a mud bank where it became covered orer, and lay buried, through all these ages, undisturbed until the recession of the bluffs carried away the tail. Underground channels destroyed the two feet.

But of these bones themselves; how can I describe their condition, I have been faithfully at work on them for over three months, (at this writing), and am just beginning to see that I will have a fine skull when it is cleaned (See Fig. 16), I have since finished it. It was preserved in a clay sandstone that chips at right angles to the bones, breaking them into thousands of pieces. Then the bones are enclosed with a heary coating of bog iron, and between bones and around them, is stone as hard at flint. The bones themselves are poorly petrified. The spongy bone not filled with rocky material. If the thin outer covering is broken through, the spongy bone within crumbles like an egg shell. If a tool should slip through the covering, the bone within is broken to fragments. How is it possible with such obstacles to ever overcome them and prepare the skeleton for study and exhibition? Well! first of all, whenever after the 


\section{We Explore Dead Lodge Canyon}

most careful scraping and cutting I got some bone exposed, I filled it with diluted shellac or a thin solution of ambroid, a cement I like better than shellac, although it is costly. Then it must be left, ( for a bone wet with shellac is like mud), until thoronghly dry, and hard. The rock, too, must be held together and strengthened in the same way. What seemed for weeks an impossible task, became possible; as I got the bones harder and harder. I had a solid mass to work against with steel tools. These were either small chisels or scrapers, made by beveling off the end of large harness makers straight awls, (made in Germany), or I nsed tools George made especially for me. He became quite skilful in tempering tools. It is needless to say that the tools that can be used in preparing one specinlen cannot be used for another. Where the rock is not too hard, a saddler's crooked awl is very useful, but with the skull referred to it would have been of no use whatever. Patience, and unremitting en. thusiasm, and the hope of success, even with this specimen the worse one to prepare I ever saw, have made success possible.

So the preparation of these Red Deer River Dinosaurs, require courage and patience, not only for me, but for the boys, working incessently and going slowly to the finish. We must have complete control of our nerves, a moment's impatience might wreck a specimen we hare sought for years. It is a great achievement to mount 
one of the noble relics of God's creative power in the past. Our laboratory is Holy Ground. The earth is a great plant, from which, for countless millions of year's the Creator has been turning out the creatures of his hand. Each, "having seed in itself." It is discouraging when I think of the multitudes that throng our Exhibition Hall, to know how few carry any thing away with them. They simply satisfy a curiosity, with little conception of the enormous energy the collector and preparator expend, in heart breaking months of exploration, and nerve trying labor in the shop. Yet some are really interested, I remember talking for an hour or more in shop and exhibition hall, with a minister of the Church of England. When he left he remarked "I feel as if I had been talking with God" so closely had I ied him to Nature's great heart. When after months of anxiety and labor we get a specimen mounted permanently for study or exhibition, we are relieved of a strain few can comprehend. The nearly complete skeleton of Stephanosaurus of Lambe, or Corythosaurus, of Brown is seen in (Fig. 16). The front limbs, the shoulders, and half the trunk has been covered and separated into two sections. I am sitting down to the right at work on the less perfect specimen. With a little restoration, however, both individuals car be made into fine mounts. What is missing in one, can be supplied by making casts of the parts present in the other. A vast amount of labor 


\section{We Explore Dead Lodge Canyon}

was expended in taking up these two specimens, done chiefly under the management of Charles M. Sternberg. We might have even lost the one that proved so fine but for him. I had only found a few toe bones and a tibia and fibula corered with heavy concretions; his labor, however. developed the greater part of the skeleton with the best skull of these crested duck-bills we have found.

The rocks of the Belly River series of the Cretaceous are quite different from those of the Edmonton. There are many layers of gray sand. stone beautifully fluted, often with outlying mushroom-like pillars (See Fig. 19), as in the picture. Lying around too, are the traveled boulders that once lay on the prairie that has been carried away by water piece meal, leaving them behind. The fluting too, is beautifully represented in this picture showing also, concretions sticking out at different levels that will sooner or later form pillars under the processes of the recession of the cliff. The concretions capping them, preserve them from destruction. Here, (Fig. 20), is a great outlying butte over three hundred feet ligh. It borders the flood plain of the Dead Lodge Canyon. In the central ground, you will notice, if your eyes are sharp) enough, Levi at work on a fossil saurians skull. This has since been figured and described by Barnum Brown under the name of Prosaurolophus. Tevi found a very good specimen of a 


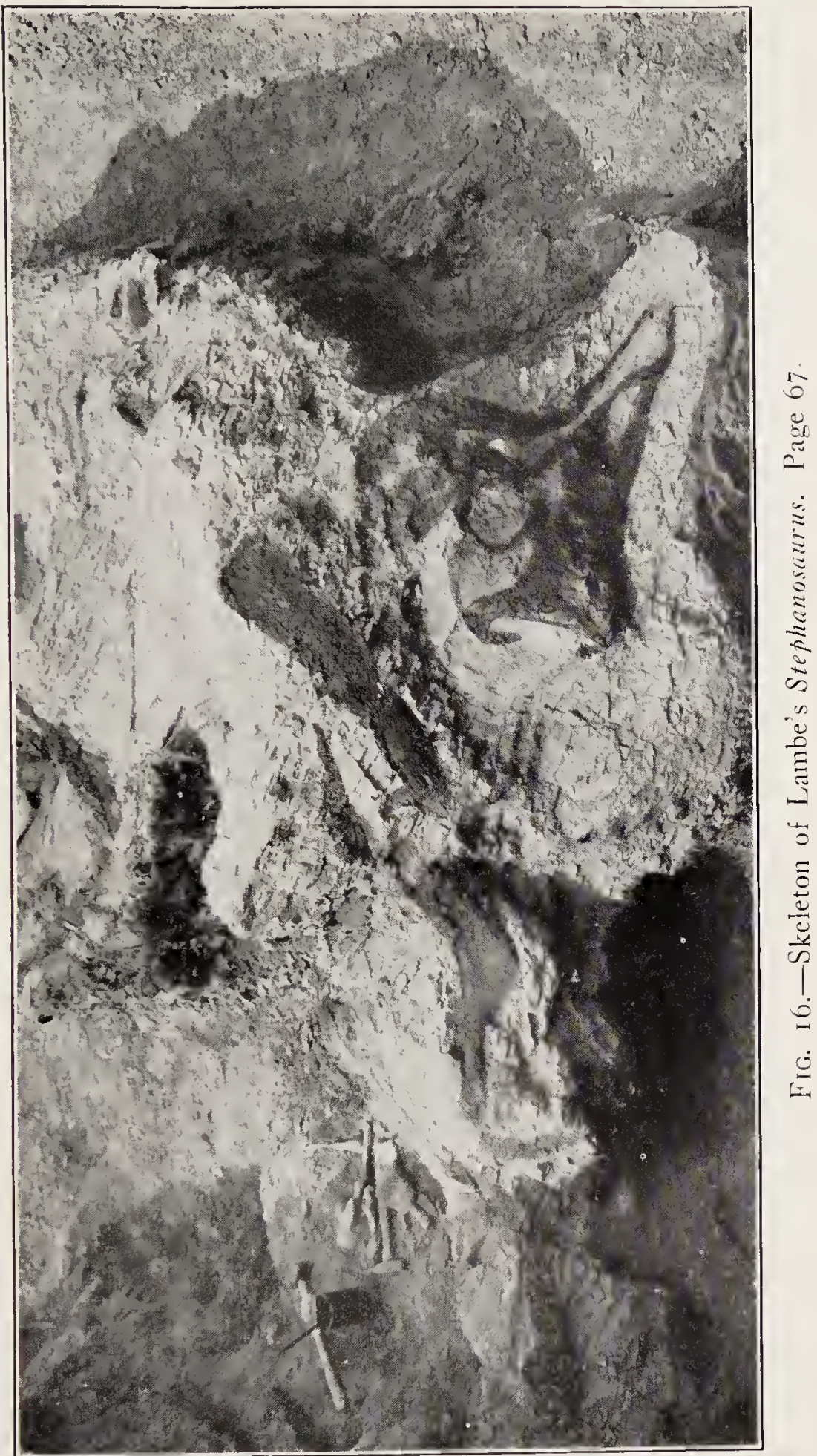




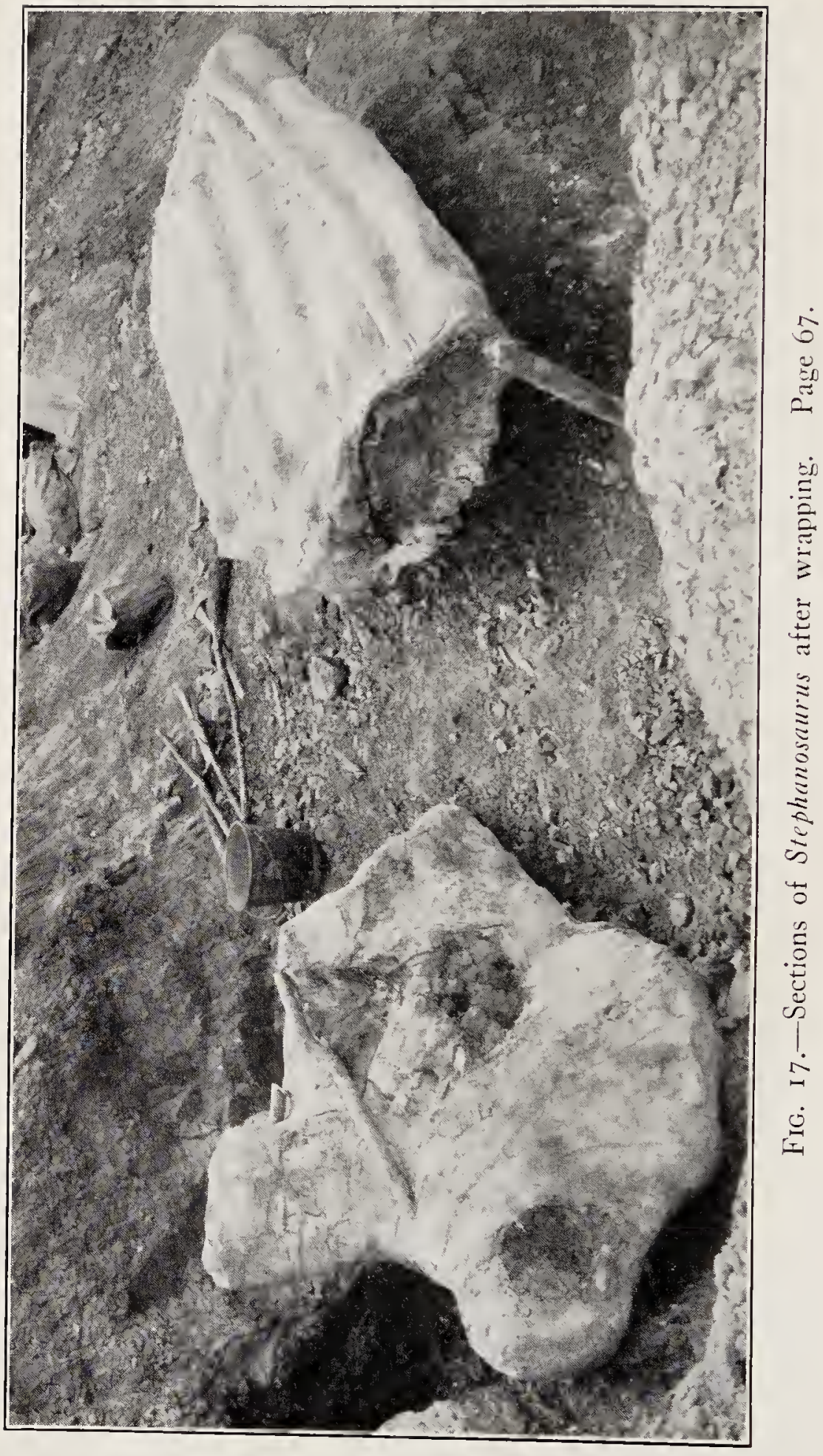


crested duck-bill lying athwart a precipitous trail down over the bad lands from the prairie. The tail was partially exposed, and not noticed by the Lndians and Cow Boys who for years had traveled on this trail (Fig. 21). Charlie found two in the same quarry. He had discovered the first one with the tail sticking ont from under a mass of clay about 18 feet high. The prospect of heavy labor never discouraged us. So we attacked the bank and uncovered the skeleton. At the further end of his specimen he found the tail of another leading still farther into the face of the excavation. As there was new surface ground to still explore we covered it with tons of earth to discourage any would-be explorer here, and went back to it the next year.

In Figure 22 the reader will see the excavation left after the two duckbilled dinosaurs were remored. During the season of 1913 , Charlie had the most remarkable success. For though he spent six weeks of incessant labol collecting his carnivore, he discovered a duckbill on his way to assist the teamster with a load. On another occasion while walking to his carnivore he found a new trachodont at the point of a hill (See Fig. 23). This skeleton was preserved in a hard siliceous concretion. During the winter of 191415 George prepared the skull for permanent exhibition (Fig. 24). It was placed in the Hali of Fossil Vertebrates, the most perfect duckbilled dinosaur skull $\mathrm{I}$ have ever seen. It is in 


\section{We Explore Dead Lodge Canyon}

its natural condition, not flattened or otherwise injured by pressure, as is usually the case. We think the skeleton over thirty feet in length, we secured much of the skin impression with it, showing a different pattern from the other known forms. Mr. Lambe calls it Gryposaurus. the high nosed lizard. It will take months of labor to prepare this skeleton. Mr. Lambe in his summary of our work says in the blue book Summary for 1913, of the Geological Survey of Canada, page 293: "The principal field work consisted of an expedition to the Red Deer River, Alberta, to collect dinosaurian and other vertebrate remains from the Belly River Cretaceous in the neighborhood of, and below Berry Creek (Steveville). The party was composed of Charles H. Sternberg and three assistants, its success is to be attributed not only to the skill and experience of those forming the party, [my three sons], but also to the manner in which it was equipped. The party was on Red Deer River from Junt 20th to October 3. The collection from these rocks, made by the expedition of 1913 , reveals in a striking manner the wonderful variety of the dinosaurian life of the period. The field collection of 1913 includes members of the Ceratops (horned dinosaurs, quadrupedal, plant eaters), Trachodontidae (duck-billed dinosaurs, plant eaters), Theropoda (flesh eaters), and Stegosauridae, heavily armoured plant eaters), Plesiosaurs, crocodiles, turtles, amphibians, and 
fishes are abundantly represented, and some mammalian remains were also found." I know of no wilder or more fascinating scenery than that in the Dead Lodge Canyon of the Red Deer river of Alberta. The great layers of sandstone are often beautifully fluted. The strata of clay between sometimes thin out to nothing (Fig. 25). The constant change in butte, and tower ridge and pinnacle, with great concretions, or small ones sticking out of escarpments, like window sills of a skyscraper. Some of the photographs will give a faint idea of the beauty of this great canyon. I here wish to place on record my appreciation of the splendid skill developed by my sons Charlie and George, who took all the photographs I have used to illustrate this book, except those to whom credit. will or has been given. Levi too, is learning the art rapidly as evidenced by the illustrations for my expedition for the British Museum for 1916. Great credit too is due Mr. Clark the head of the Photographic Division of the Survey who developed and printed these fine photographs. Neither can I forget the kindness of both directors under whom I served Dr. Brock and Mr. McConnell, who presented me with full sets of the photographs we liave taken in field and shop, and Museum and also lantern slides of many.

While in camp, often after supper when our day's work was at an end, in a reminiscent mood, I told the boys stories. They had often heard 


\section{We Explore Dead Lodge Canyon}

before, of my adventures in other fossil fields, and other days, but as distinctly printed on memory's pages, as if they had occurred but yesterday. I remember recalling an adventure of George and myself in the chalk of Kansas. We had been up towards Monument Rocks and were returning to camp at Elkader, at the mouth of Beaver Creek in Logan county, when we observed a storm gathering in the northwest, and northeast quite threatening indeed. We were three miles away, and drove like Jehu to get to shelter before the storm broke upon us. However, in spite of our efforts, the storm orertook us on the level prairie. The thunder clouds threw forked lightning to the ground around and in front of us. Where it struck the dry grass of the prairie a little cloud of dust would rise, and the grass would take fire to spread a few yards in a circle, when the rain would follow up and put it out. The thunder cracked in deafening peals with tongues of electricity following at once. A calf was struck and killed a short distance from us, but we escaped with a good soaking.

A still more remarkable incident happened to Levi and me at Livingstone's ranch in Gove county, Kansas, seven miles south of Quinter. Our tents were pitched on Hackberry Creek near the ranch barn, a large affair covered with sheet iron. Towards evening we saw a great dust cloud coming towards us from the northwest. I sent 


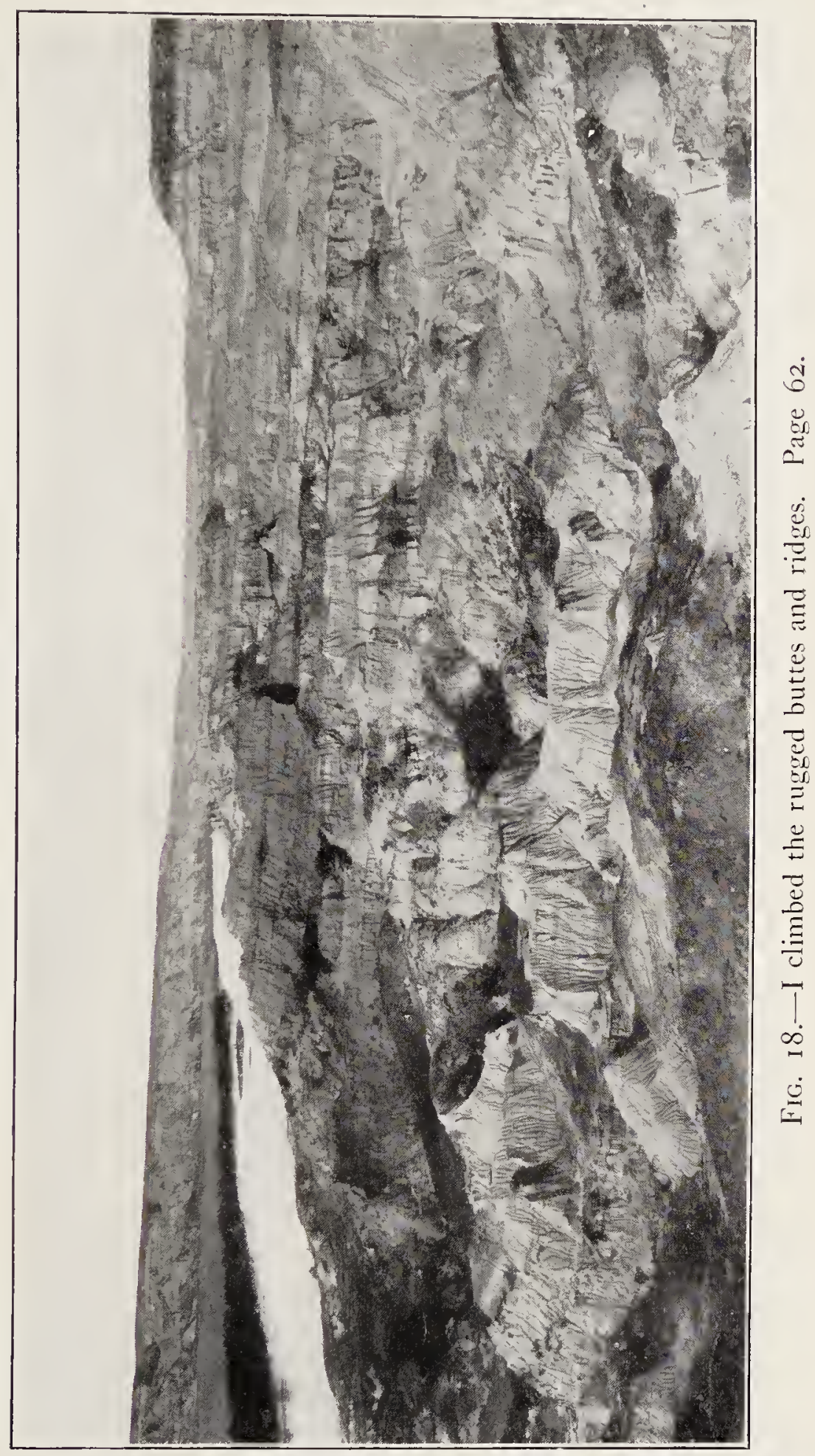




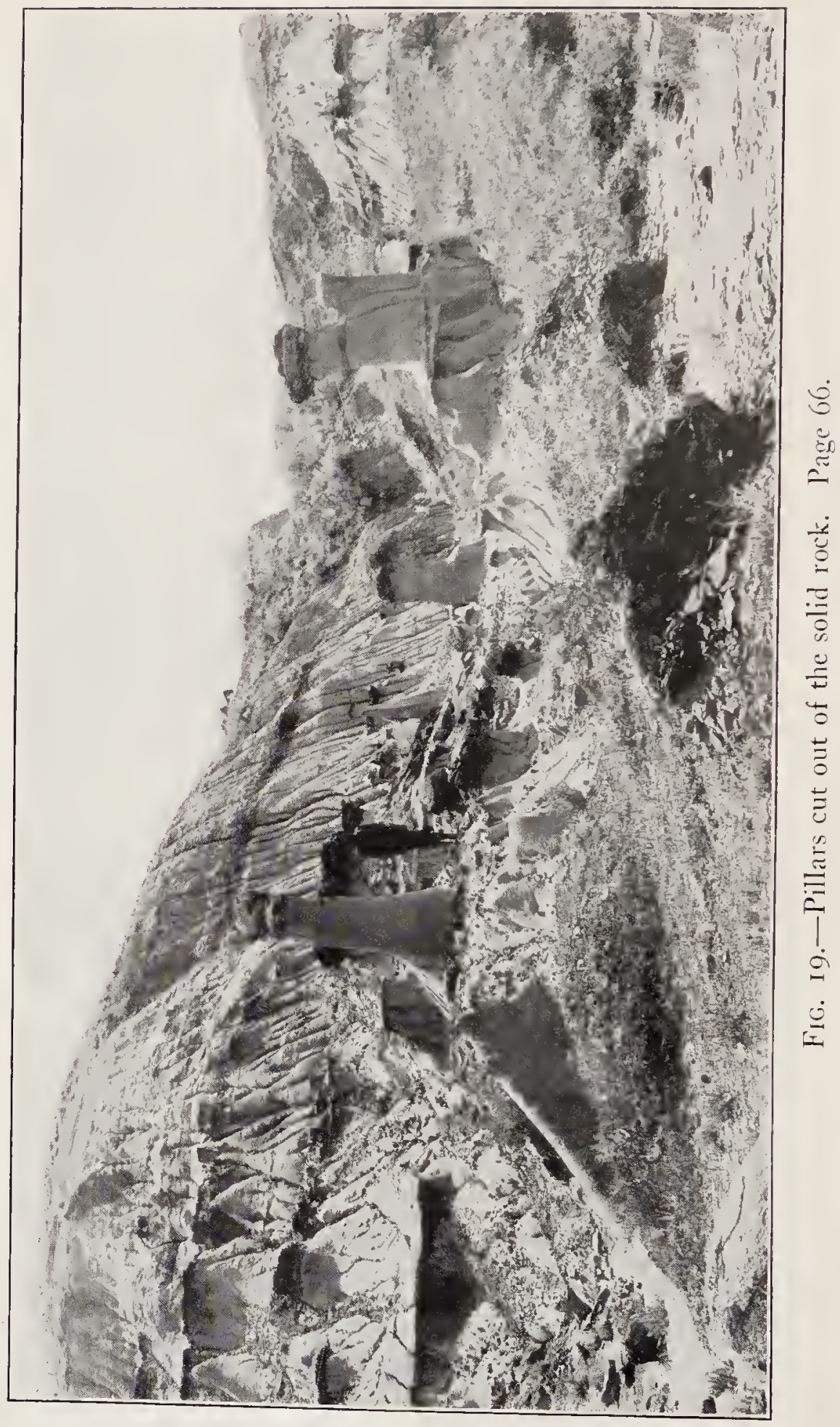


Levi to the barn to put the horses in, they had been standing in the corral near by. He had hardly accomplished this, when the stor'm was upon us; the gravel and sand beat on the iron roof like hail. He stood in the door with a lighted lantern. I feared the roof might fall in and break the lamp. and set fire to the hay, and I shouted to him to put it out, but he conld not hear me. It became instantly dark as midnight, as the air was dense with gravel, sand and dirt driven at terrible speed by the raging wind. I started to the barn a hundred yards away, and got my face cut with the flying sand, my eyes blinded with dirt. But I reached him and put out the light and we attempted by holding each others hand, to reach the tents. Suddenly we saw an electric light hanging over our tent, on a telephone wire that was stretched above. Then another and another sparkled in the darkness along the line and lighted up the posts and wire fence on either side of the lane we were follow ing. As far as we could trace the telephone wire, little lights swung in the wind as if some one had turned on a switch to light us to camp. It was certainly a little uncanny to say the least, and if I had been superstitious, I might liave been frightened. Levi went off to bed in another tent, I watched the strange phenomenon until I too, got tired, and turned into my bed and went to sleep. All this is part of a Fossil Hunter's day's work. Although this was the first time I had ever 


\section{We Explore Dead Lodge Canyon}

seell an exhibition of this peculiar kind of electric display on the prairie I was sure it represented what is called St. Elmo's Fire at sea.

On July 18, 1913, I note that I had worked all day on Charlie's large trachorlont which Mr. Lambe called, as I said above, Gryposaurus. Twenty feet of the skeleton, besides the head was present. On page 23, Book A, field notes for 1913, I say: "The skull is 3 feet 3 inches long. Distance between the orbits, 9 inches. It is 19 inches from the margin of the mandibles to the top of the skull. Which has a high narrow set of nasals, with curved beak shaped like Brown's New Mexican Trachodont." Then again, on page 25, "I have worked all day on Charlie's huge trachdont. It is a wonder, puorly preserved in a huge brown flint concretion that is shattered into irregular fragments, that break through the bones as well. The under part of the skeleton, however, is in grey sandstone and clay. The body lay on its left side, then took a turn and rested on the ventral surface. The ossified tendons are different from the ordinary duckbills, both with or without crests; they are often barbed in the center and bifurcated at one end, with the other flattened. This specimen is evidently new. I am very anxious to save it."

The fluted pyramids and Gothic towers stand out distinctly to the south of the specimen in the early morning and after sundown: but in the heat of the day the colors blend so, the sharp out- 
lines of the different strata are not easily distinguished.

On July 19th' Mr. Baruum Brown went down the river with his scow, motor-boat and rowboat, bearing his party of five men and all his outfit. They intended to camp on Sand Creek, which they did, and never left that richest of all the camps in the Belly River Series in Dead Lodge Canyon for three seasons; the richest, doubtless, in history. I believe there are more exposures of the strata there, than all the rest of the exposures put together. I could not leave the great carnivore Charlie had found. Or my wonderful Chasmosaurus skeleton, showing the dermal covering for the first time in the history of horned dinosaurs. Neither could we leave the splendid skeleton of Gryposaurus, or my new duck-billed dinosaur to follow Brown and share with him the gleanings of that rich field. Consequently, with his five collectors, all first class men, filled with energy and enthusiasm, with such a leader and hunter, it is little wonder that he securer that year a great collection, now being mounted in the American Museum. He also spent the seasons of 1914 and 1915 there also, most successfully. The Belly River beds below Steverille and near our camp, consist chiefly, as already mentioned, of strata of silver grey sandstone, alternating with yellowish or ash-colored clays. Notice the picture (Fig. 25), how the dark clay bed feathers out. The exposed clay beds crack 


\section{We Explore Dead Lodge Canyon}

after a rain, like the mud flats of the river, and curl up on the surface when dry. The fluting of the sand-beds is due to the fact that they contain so much clay, that during a rain, the whole surface is puddled and the water cannot pass through the thin coating of mud, and runs off the surface in countless rivulets sculpturing the soft mass into the most beautiful flutings imaginable. This we have often noticed before.

There are neither wells or springs in these beds, not enough water penetrating them to produce either. There are, however, many underground passages through which the water finds its way during a rain to lower levels. Near the top of the badlands, or anywhere through them, often, a sink hole is formed. The water first 'forming a cistern, until a way is found for it downward, and the water escapes at last through the mouth of a cave, it has formed. These passages are choked with fallen rock from abore, or from the sides, which in turn are disintegrated and are carried out by water until we have a series of natural bridges over the chasm, which break down at last, and produce a ravine. We used water from these cisterns on several occasions to make plaster. There was one containing many gallons near Charlie's carnivore.

We were often bitterly disappointed in our finds. Take for instance Levi's crested dinosaur. He found some exposed tail vertebrae a little to one side of a horse trail that came orel the rocks 
from the open prairie above, down to a branch of One Tree Creek, not far from our camp, there Levi found 20 tail rertebrae, the pelvic arch, and hind limbs and many ribs. So as we progressed in uncovering these we felt confident that the entire skeleton was buried there. We were mistaken; no head, neck or front limbs were pres. ent. From the fact that some of the long pelvic bones had been snapped off, we concluded the missing parts had gone in death to gorge a living specimen of Gorgosaurus, the Tyrant of the Everglades. Then Charlie remored tons of rock from where he thought the tail of his Gorgosaur lay, only to find it had taken another direction, and the same amount of energy was necessary there as he had wasted on a false scent.

In my notes of the 11th of July, I speak of the windy day: "So strong was the current as I clung to the steep and barren slopes; I would often have lost my footing but for my faithful pick, whose point I drove into the soft rock when I felt as if I was about to be blown into a deep canyon. I would cling to my pick until there was a Iull, or I had secured a better footing. My pick, under the providence of God, often saved my life. Once in the brakes of the Permian beds of Texas, on a Saturday evening a great storm threatened. I though we could reach Mr. Galyean's house before it burst. His son was with me, a boy of about 15 eyars of age. We had gone only a short distance, however, when the 


\section{We Explore Dead Lodge Canyon}

rain fell in sheets, not only drenching us to the skin but filling innumberable ditches with water running like a mill race. These we must cross. I remember we passed through the same patch of weeds repeatedly, so I knew in the darkness we were walking in a circle. Every few feet was a deep and narrow ditch full to the brim with red muddy water. I found these rushing streams by pushing my pick ahead of me, as the only time we saw anything was when the lightning flashed. At last we got sight of the light in McBride's house a mile up the creek from Galyean's. We thus secured the direction and thought we were all right, but without our knowledge, some one moved it from a south to an east window and we got off again, and before we knew it were slipping down into the roaring Coffee Creek full of driftwood. If we had slipped into it, both of us would have been lost. The boy had hold of my coat tails; I struck the point of my pick into the muddy slope and swung around with John hanging on behind describing the arc of a circle. The pick held while we dug holds with our heals to support us until I could reach upward and take another hold with the faithful pick. Thus we got out on the level flood plain of the creek. I then allowed John to take the lead, and he took me as if by instinct, safely to his father's house where we were soon drying our clothes before the fire-place, heaped high with blazing cottonwood chunks. 


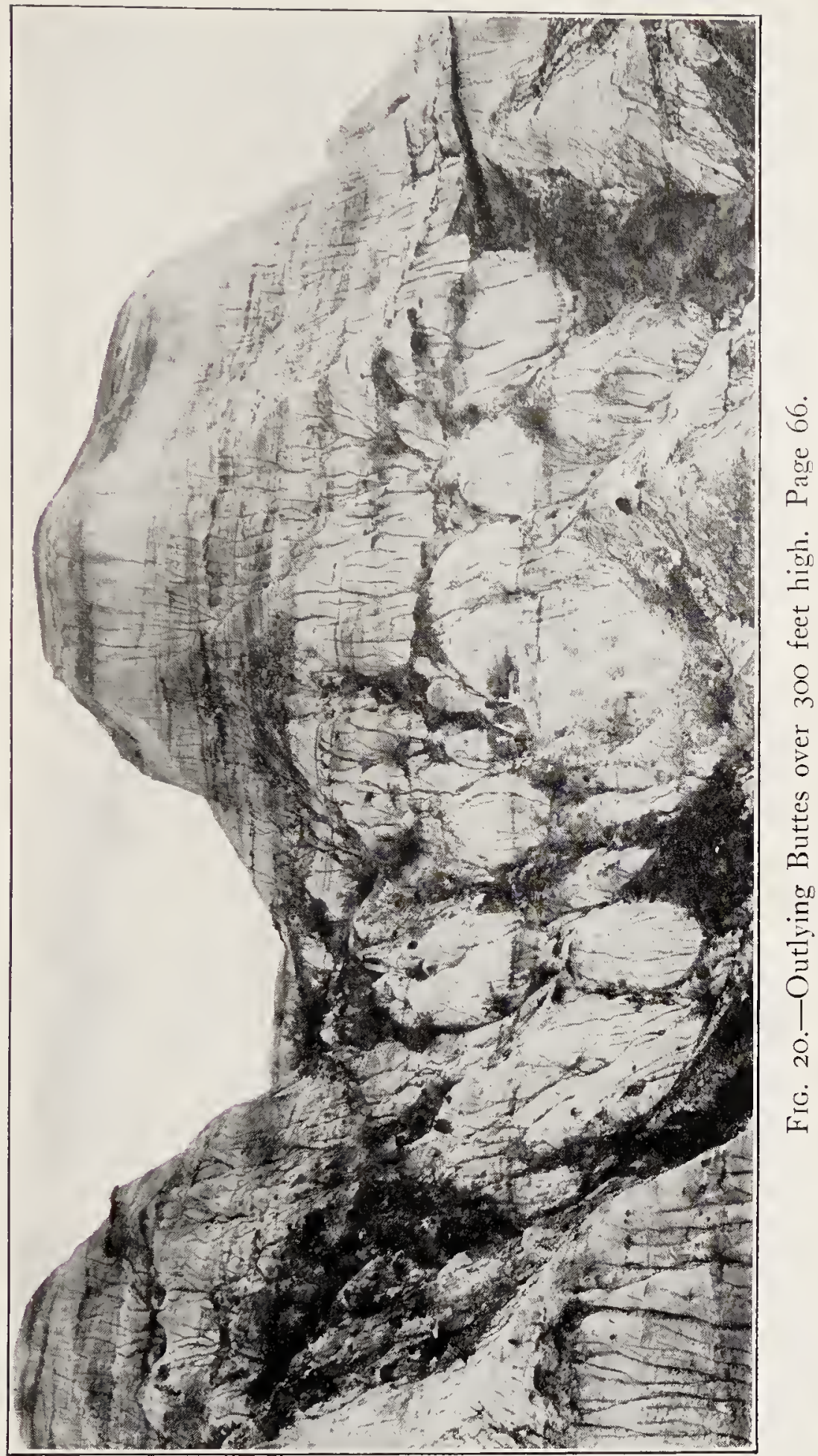




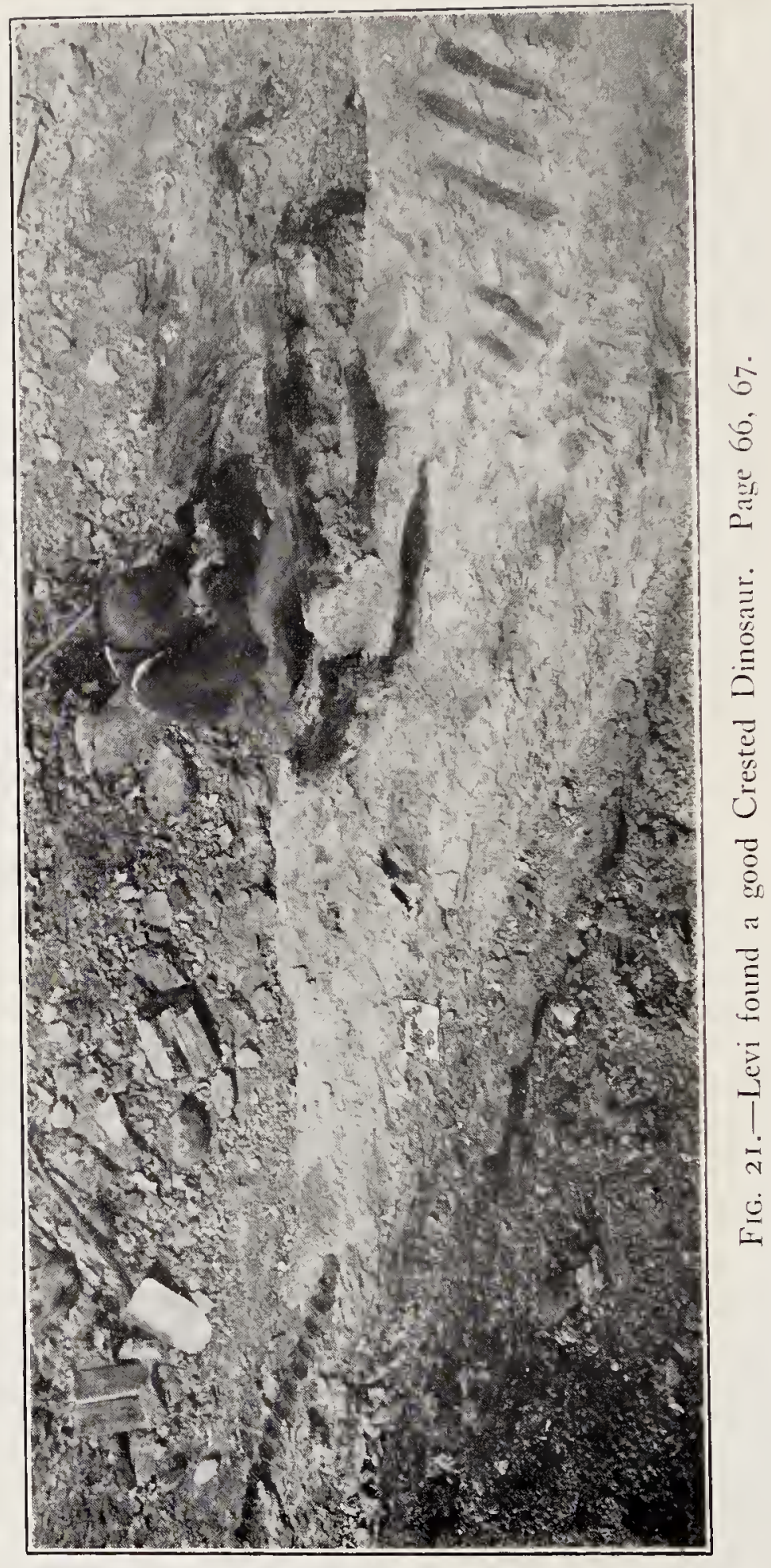




\section{We Explore Dead Lodge Canyon 77}

Mr. Lawrence M. Lambe the Vertebrae Paleon. tologist of the Survey visited my camp on the 12th of September, 1913. We visited all the different localities where were the different specimens we were collecting, much to his delight. He described many of them the following winter. In a large exposure near Steveville, we were led by my son George to a fine turtle, one of the largest forms. The sheli is over two feet long. 


\section{CHAPTER V.}

HUNTING HORNED DINOSAURS ON THE RED DEER RIVER.

Please, dear reader, return with me to the first camp we made below Steveville (Fig. 15). I would like to tell you of our successful hunt for horned dinosaurs, the reptiles that carry on their shoulders the largest known skulls of any land animal living, or dead. I had gone around the flood plain to the mouth of a ravine below camp and following it up to its head searching the denuded exposures, on either side. Suddenly, $\mathbf{I}$ stumbled on a couple of orbital horn-cores of a new genus of these strange creatures. The nasals and much of the face had been disintegrated by exposure to rain and frost; one complete lower jaw and part of the other was in place, however. With eager hands I used my little pick and digger, cutting into the face of the cliff. The horn-cores were pointed heavenward. I soon got behind them and followed up the great crest that projected backward into the rock, of which some fifteen towered above; I needed help and returned to camp a mile over the hills, for the boys, George and Levi responded to my call. The rock was thrown out and scraped away with team and scraper, tons on tons of it, my enthusiastic as- 
sistants threw down. We soon found that most of the skeleton was present, and it required $x$ large floor to lay all the bones bare. At least enough of them so we could take them up without injuring them.

While working around the skeleton, we dug up what appeared to be impressions of mud cracks, but Charlie who came to visit us, concluded at once they were skin impressions. This seemed too good to be true, as none were known before from horned dinosaurs. We were soon, howevel, forced to believe it, when a large chunk of rock broke in two and revealed the regular casts of polygonal scales, the upper and lower sides. They were arranged in the most beautiful mosaic patterns, some mere tubercles, as in the trachodonts, especially under the limbs. Along the back there were larger scales, often rounded or six sided, from two, to two and a half inches in diameter. This was new, and unexpected, as the men of science who had made a special study of the horned dinosaurs believed they had a thick skin with heavy dermal scutes, or plates inserted into it, as a protection against the rapacious carnivores. But here, as in the Trachodonts, we were so fortunate as to prove what we had prover so oft before, "The wisdom of man is foolishness to God." How could it be otherwise. Yet I am free to acknowledge there are no class of men so positive in their conclusions. I once hear four different men at a Scientific Academy deliver 
four papers on the Creation of the world, each one was different and each man thought he was right. I have proved too often in my own experience in the field that I was mistaken, to doubt that other scientific men might be also. I could write a book about the mistakes of scientific men but will not burden my pages with them except as I discover facts absolutely different from those commonly accepted, as in the case of my Chasmo. saurus under discussion. In the past men have been too anxious to publish results before complete skeletons have been found and almost invariably, when one is found, it does not bear out in its own person the expectations of their authors.

This field, so rich in material, in which we get the skin impressions, as well as complete skelstons enables us to speak "as one having authority" about them. Here then, although we have an animal with limbs of equal length, the body was corered with thin scales arranged like mosaic-work in a pavement. Without much doubt the skull had been subjected to great pressure for many ages. The rock in which it was embedded has been lifted some twenty-five hundred feet above the position it occupied when it was mud at the bottom of the lake. Mr. Lambe, the Vertebrate Paleontologist of the Geological Survey of Canada, has called this remarkable dinosaur Chasamosaurus, on account of the great chasms or gaps cut into the crest and skull. As 
far as I know this is the most complete skull known of this species. While at work on iny specimen I learned some remarkable things. There is always an opening between the horns of these saurians. In Triceratops, it is midway between the end of the beak, and the crest. In this specimen, however, it is two feet from the end of the beak, and three feet to the further end of the crest. Then, though the skull proper in front of the crest is quite heavy and strong, and with lar'ge mandibles, and rather a large horn over the nose, as compared with the small ones over the eyes. The crest seems to be built for strength, as the central bar, the side and distal bars are strong, but bereled off to the large openings; and masses of bone are scooped ont of the skulladapted evidently to add to the strength, but to reduce the weight. This is not to be wondered at, when we study the skeleton. For we find the neck-crest not only covered the neck and shoulders, but extended back over seven of the dorsal vertebrae, to within a few inches of the pelvic arch. I do not think the animal was much bigger than a cow: about 9 feet from beak to drop of the tail; and the latter was short, barely dragging on the ground. When cutting a path through the dense sub-tropical foliage of reeds, rushes and grass, with many a bog, he simply parted the rank vegetation with his triangularshaped head and crushed it under his four large spreading feet. But when he was attacked, 
down went the head, up went the crest, and a shield well armed with horns on the face, and horny projections along the sides of the crest was instantly presented to his foe. As the only vulnerable place of attack, to the tiger of the everglades, he would try to strike with his powerful claw-arined feet somewhere in the flank, for then he could lay bare the vital organs and soon destroy his prey.

But our Chasamosaurus was on the watcl to prevent this very thing. The grass is beaten dowll, a ring is formed, and he often rushes forward with open beak. If his pincher-like bill once closes on the quivering flesh of the carnirore, he would surely get his "pound of flesh." If a moss-covered bog is within reach he would try to get to it, for then he would plunge in, and be safe, as no bipedal flesh eater will dare to follow. Our herbivore, however, can swim through it, or through the morass as easily as a living hippopotamus.

You will notice the horny-beak is shaped like that of a great turtle, though the lower jaws supporting it below are two feet in length. The crest behind, where it orerhangs the back, is nearly four feet along the curve. We approximately can guess the distance from the lower margin of the jaw to the top of the nasal horn to be nearly two feet. At each angle of the cross-bar behind on the crest, is a long horn-covered spike, while the sides of the crest are also 


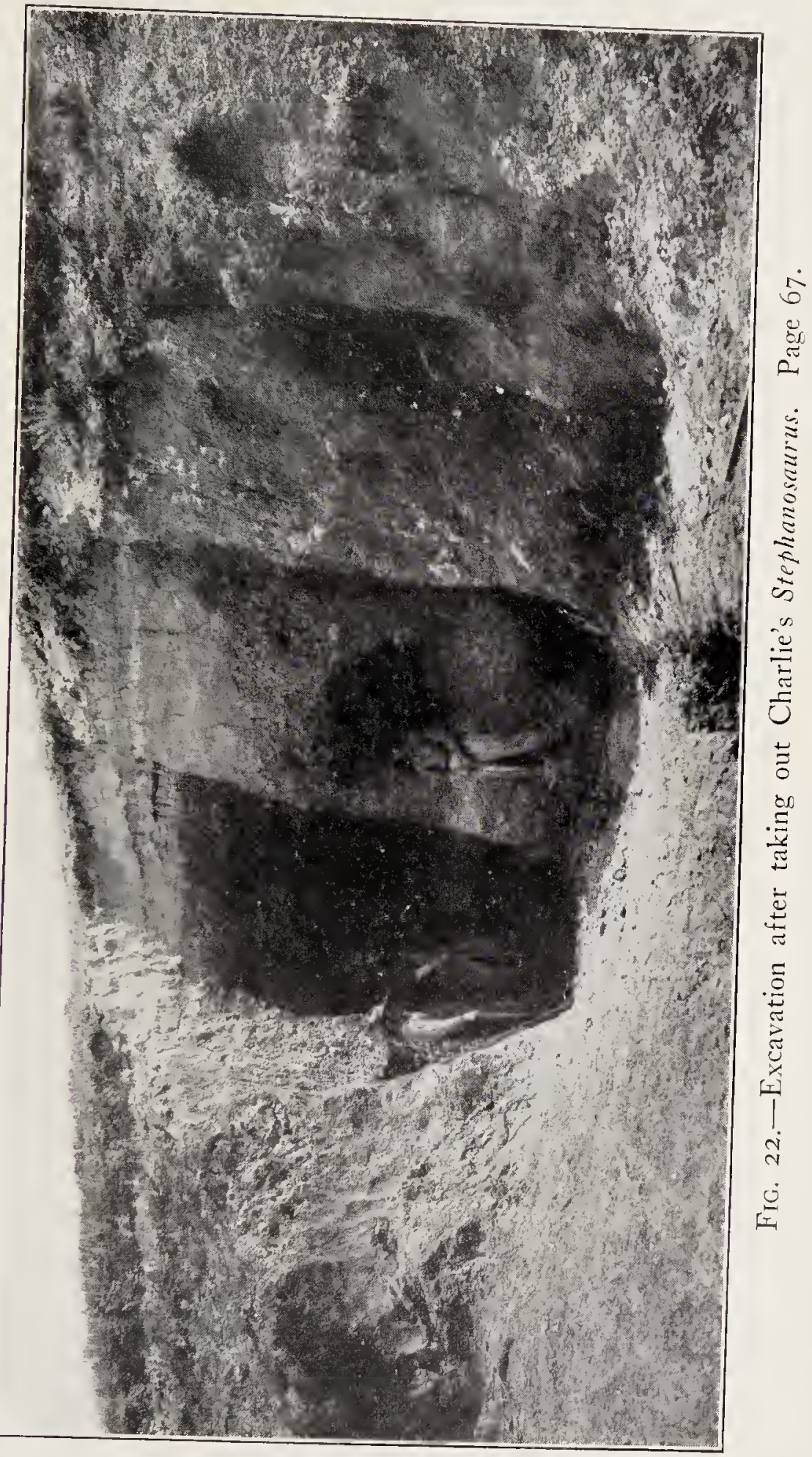




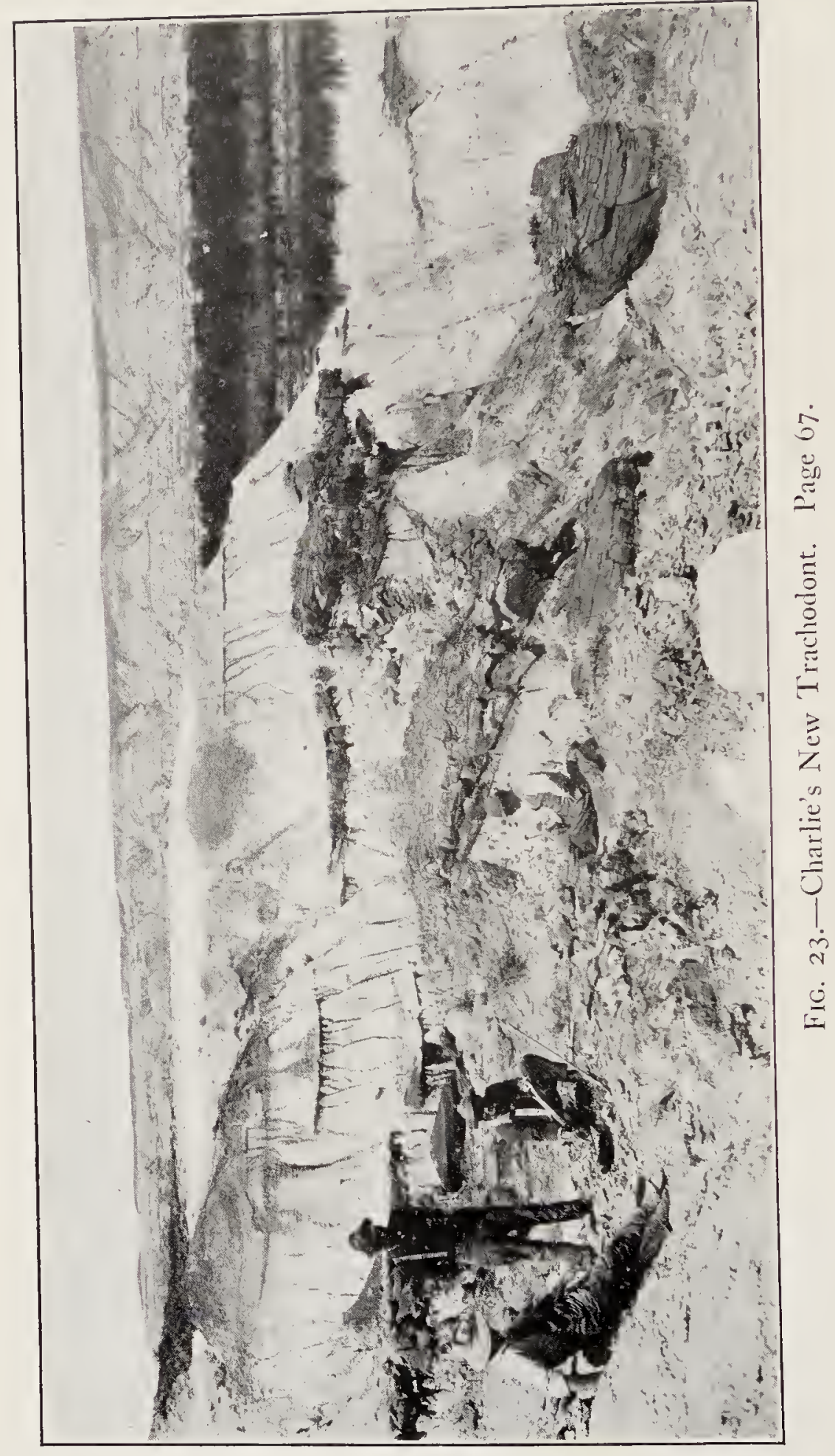


armed with smaller and blunter ones. The orbital horns are round and conical, not much over six inches in length, while the one on the bridge of the nose is orer a foot long.

Now, with the rapidity of thought we will return to our work-shop. When George prepared the head of this fine specimen, I found it was the exact size of the one I found in 1913. I therefore took a cast of the parts that were missing in mine. In order to accomplish this, I covered the front of the head with lard oil and then with molding wax, being careful to make it in sections so it would come off and be heary enough to prerent distortion. When all was ready and we had colored our plaster to l'esemble the fossil boneno small task, by the way, as we had to learn to mix colors as well as do the work of a sculptorwith wax. Then the mold is separated from the skull and stuck together, plaster strengthened with dextrine is poured into it, and on hardening I got an exact fac-simile of the original specimen. This I fastened to my skull in which these parts were missing, and this gave us two specimens for public exhibition. Otherwise we could not have exhibited this dinosaur, as it would not have done to guess at these missing parts, as the early scientists were in the habit of doing. Now we can point to the complete specimen should anyone doubt the truthfulness of the restoration. All through the Belly River Series of rocks are bone-beds. There are two below Steveville, one 
near the top, and the other near the bottom of the exposures. 'They lie usually on a bed of clay, as if they had been drifted in from a lake (into which, they had been carried by a river) and lined the shore in the mud. In some places I secured hundreds, yes thousands of bones and teeth of many species, as well as shields of sturgeons and the enameled scales of gar-pikes as perfect as if picked up along a recent lake shore. There were also bones and shells of a great variety of soft-shelled turtles, and others, with beautifully sculptured shells; they range in size from less than six inches across, to over two feet. Crocodile bones, and the dermal, or skin plates of plated dinosaurs, were common. We secured hundreds of the parement teeth of the ray Cope called Myledaphus. also countless vertebrae of the reptile Champsosaurus. Probably all the species of this rich fauna, are repre. sented in these bone-beds. The fragments we collected came in good play, when Charlie and I mounted the Trachodon skeleton. As we were able to restore the missing tail from the caudal vertebrae we picked up in bone-beds in the Edmonton Series, near Drumheller, Alberta. We found many hol'n-cores also in the bone deposits. Although we found many of the long bones we were unable to take up many on account of the expense. First, the bone has to be located, i. e. discovered. Then likely a road has to be built to it in order to haul in to it plaster and water. 


\section{Hunting Horned Dinosaurs}

After one side is uncovered and plastered, it has to remain twelve hours to harden. Then we must return to turn it over and plaster the other side, allowing it to harden before we go after it with a horse and sled. During all this time we might have found a complete skeleton.

When we reached our big scow in 1914, we found the seams had opened along the botton and we were forced to recaulk it. The first thing was to clean out the old oakum and coal tar. Our eyes filled with the poisonous tar irritating them almost beyond endurance. After that was done, with arms above our heads, we drove in the oakum with caulking tools and then retarred the seams. I will acknowledge I did not do my full duty here, I spent most of my time in the hills exploring, which was more to my liking. This trying work the boys accomplished at last. Then came the supreme test. Will it keep out the water? We slid her down on skids into the river, and she rode as buoyantly as a duck, though not so gracefully.

We lad picked out a place to camp three miles above "Happy Jack Ferry." So George, Charlie, and Mr. Johnson, hauled the scow up to the camping ground with our moter-boat, accomplishing a feat, I had thought impossible. Fortunately they had a strong wind in their favor; and the tents pitched on board, acted as sails and helped them breast the current. Levi and I moved the lumber up to camp in our wagon 


\section{$86 \quad$ Hunting Horned Dinosaurs}

pulled by our team of horses. We crossed many narrow gulches, and were obliged to dig roads across them. In fact we got stuck in the mud of one, where back-water from the river had deposited several feet of mud in it. We got into camp, lowever, ahead of the scow. In my note book I often speak of the terrible heat of those days. We had hot work on the rough exposures without water. Who of us will ever forget, when at night, we returned to our camp, how we lay with faces half submerged in the cold water of the river, and drank from her refreshing flood until we could drink no more. Drinking often a quart or more without injurs. The hardest work of all was to tramp over the burning beds without success. How many days we spent in useless effort. Near this camp, however, Charlie got a fine skull of a new trachdont or duck-billed dinosaur, described later by Mr. Brown as Prosaurolophus. Near here, also, George found his famous Chasamosaurus belli, Lambe. Mr. Brown, howerer, retains Professor Marsh's name of Ceratops. Here too, I secured the complete club at the end of a plated dinosaur's tail, of which I will hare more to say later. Showing as has been my experience that untiring effort will accomplish results in the fossil fields as in every walk in life.

During Charlie's and my absence in Montana, George found a large skeleton of a Corythosaurus. The remarkable part about it was the com- 


\section{Hunting Horned Dinosaurs}

plete limbs in position. It was discovered in $\mathrm{Mr}$. Jackson's pasture. Now Mr. Jackson is an old cownan. He was range boss for the brother of Admiral Beresford of England, who built a ranch here. On Bereford's death, Mr. Jackson took possession of the ranch and the ferry is named "Happy Jack" after him. In fact he is quite a noted character and one of the few old cattle men living here.

At this camp too, Mr. Patrick Disney, from Oxford University, England, joined my party as a guest. He came to these wilds to learn something about fossil hunting. He was indeed helpful, and welcome, but the war breaking out he started for the front, he wanted to be, and was among the first to join his colors from Canada. We learned later he became a gallant officer in the aerial fleet.

We continued to suffer all summer from the intense heat. The mosquitos, however, were not as bad as usual. All the grass on the prairies dried up. The crops were a perfect failure. But for the liberality of the government in supplying the homesteader with food, through the winter and spring and seed to plant, they would have been obliged to leave the country. This timely aid, however, enabled them, owing to the great rainfall in 1915, to reap the greatest harvest in the history of these people, so far east of the mountains on the semi-arid plains.

On August fifth, we succeeded in getting our 


\section{8}

\section{Hunting Horned Dinosaurs}

scow some two miles below "Happy Jack Ferry," (See Fig. 32) to a canp we made near a specimen George had found of a plated dinosaur. Charlie and Disney brought down the motorboat, but owing to the very low stage of water, they were in it, most of the time, hauling the boat throngh sand, by main force. Our scow floating with the current beat them to the landing. We left Levi to haul all the fossils from our upper camp to Denhart on the new branch of the Central Pacific Railway, between Swift Current and Bassano, Alberta. For two months George labored with never less than one assistant on his plated dinosaur, the prize of the season. It seems that some caudal vertebrae were seen by him sticking out of a lard silicous concretion in the face of a bluff, with thirty-five feet of sandstone on top. This was tough and hard to dig up. He used blasting powder as you see in two pictures where George is running away after firing the fuse, the other shows the explosion. It took a month of constant labor to get down to the concretion and another to cut away enough of it, so it could be handled when cut in sections. The constant hammering opened closed seams in the flinty rocks so it could be removed in chunks, with the sections of the fossil within them. George secured the pelvic arch, hindlimb bones, many ribs, caudal and dorsal vertebrae (likely the entire column in front of the pelvis), the skull, with its necklace of dermal plates 


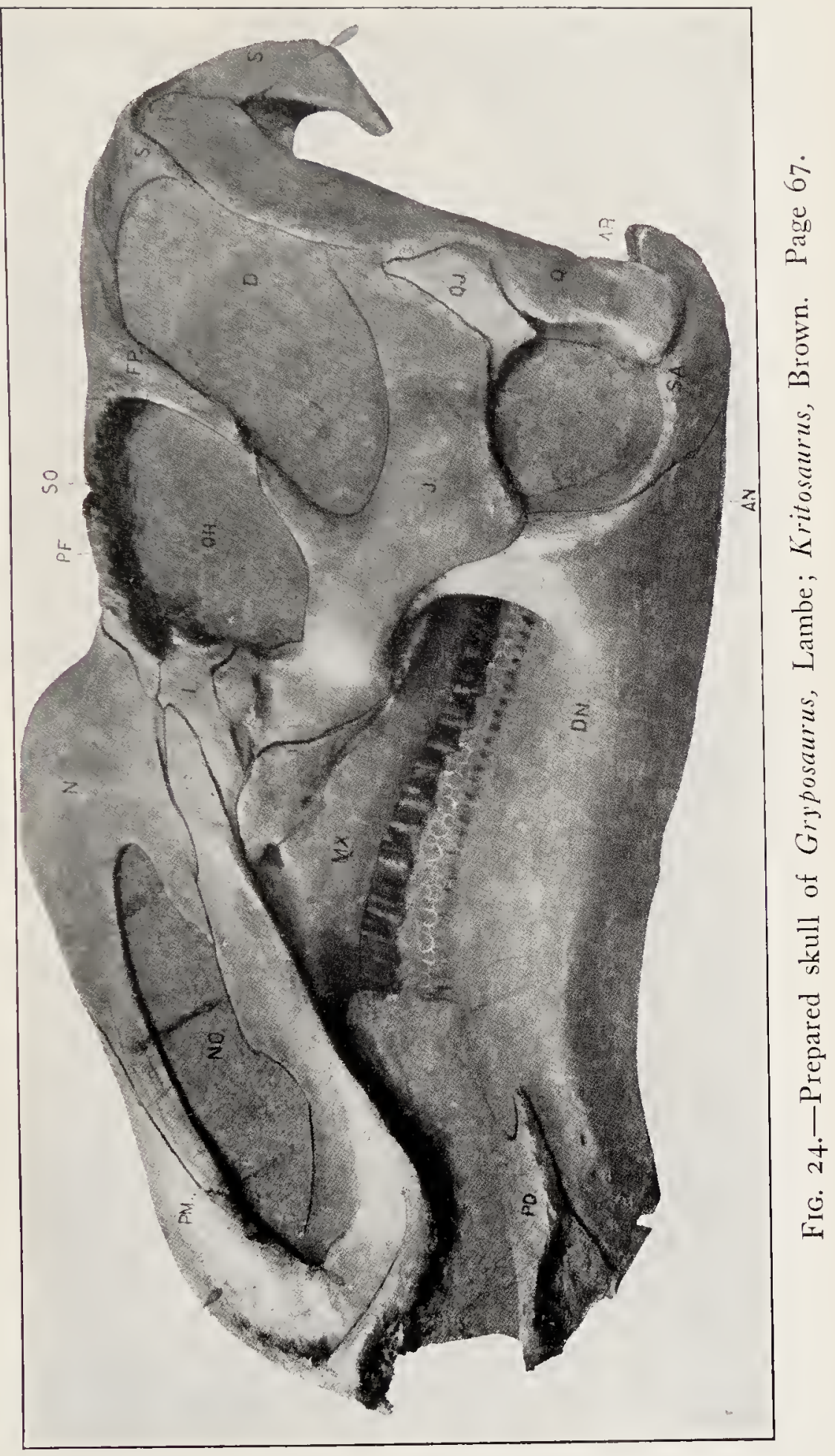




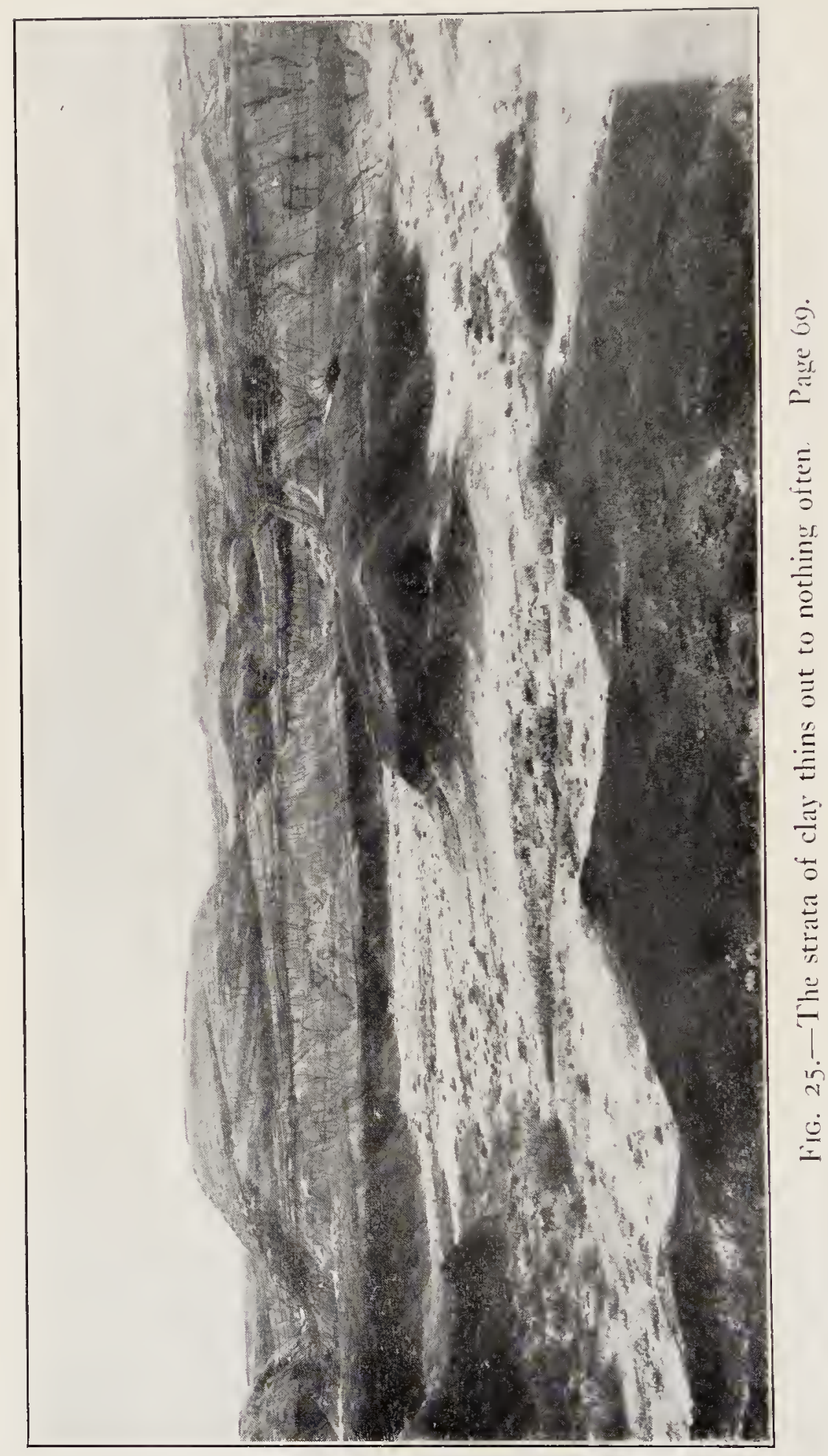




\section{Hunting Horned Dinosaurs}

behind. Then there were many of the huge plates though not all in position.

The figures show the quarry, and the road we made with four horses straining to haul the sections out. You will also see George running from the quarry after lighting the fuse, and in the next picture the explosion. We expended far more labor in this quarry than any we found, or on any other individual specimen. Yet our labor was nothing compared to what must be expended before the skeleton is mounted, owing to the difficulties of preparation. The last picture in this series shows the amount of labor required to throw out the loose material, as well as the beautifully sculptured rock in the vicinity. 


\section{CHAPTER VI}

PLATED DINOSAURS THE MOST UNIQUE OF THEM ALL

When the frost was on the bull berry, we experienced the strange sensation of making jelly in camp. We beat the berries out of the bushes, in which they clung in clusters around sharp thorns, on to tarpaulins spread below on the ground. The single berry is about the size, and color of a red currant. We filled our motor boat full of boxes with the acid fruit, and drove it to our scow. There we took pails full of the berries, and sank them into the clear water of Red Deer river. Then stirred them with a stick, so that all the leares, decaded fruit, and bits of branches or other foreign matter could float away down the river, the perfect fruit settled to the bottom. The fruit was then cooked on. our large camp stove until thoroughly done, when it was pressed through muslin bags, and cooked as long as there was any scum rising to the surface, which was carefully skimmed off the boiling surface, Then equal parts of sugar by weight was put in, the moment it was dissolved the mixture was taken off the stove and put into Mason jars. When cool it was a fine, reddish colored jelly. We made twenty-four gallons, or 
six gallons for each married man in the party. In camp we used it constantly, and it took the place of all other fruit and pickles. As usual, we were unable to get our fossils out of the ground before cold weather came. We secured fifty boxes weighing about twenty-five tons. I am happy to report, also, that after Charlie found his Centrosaurus or Monoclonius skull, and after I had spent four weeks of the most strenuous labor of which I am capable, I succeeded in getting a very good skeleton from the pelvis to the end of the tail, of a crested duck-bill. It was especially interesting, because nearly all the impression of the skin was present in a large section of the tail; giving also, the contour of the tail immediately after death. This was the best tail of a trachodont we found. While we were working early and late to get out the material before the real cold weather set in, our horse Bob, in going up a steep and narrow sled road corked his mate, the bay mare. She bled badly, and was put out of commission temporarily. Luckily, Mr. Bestrum, who was assisting us with an extra team, had another horse who took the injured one's place.

On the twenty-fifth of September, 1914, we got our scow dismantled, and the next day out on land. In the meantime we camped on the sandy flood plain of the river, near our scow. One night my tent blew down on top of me asleep in my cot; however, these are small matters, and 
soon forgotten if I had not referred to them in my notes. On the tiventy-eighth, we hauled in our last load of fossils and loaded our car at Denhart. This point was a switch on the open prairie; the store building was deserted. A miserable day, with the wind blowing a gale, from the north. I built an oren of some loose bricks, that were lying about, and cooked a meal as best we could, on the wind swept plain. It was four o'clock in the afternoon before we started on our thirty mile drive to Brooks, where we were to take our train homeward bound.

We lost our road, or rather it petered out, as they say in the west, and with the brilliant moon riding buoyantly in the heavens as a guide, we pressed on over the rough prairie sod. Suddenly as if to amuse our tiresome journey, God's Moving Pictures, The Northern Lights burst upon us in all their glory. It seemed as if a heavy map was suddenly unwrapped in the sky, the folds taking a fan-like prependicular radiate shape, then another and another, was unrolled, until the whole northern arc of the heavens was vibrating with light in white bands, edges in colors of many delicate and exquisite tints. At eleven o'clock that night, stiff and hungry, our solitary wagon rolled into Brooks, and an ambitious Chinaman, soon had on our table a hot dish of beef, and onions we ate with the relish hunger gives.

When we went west in June, 1914, we stopped 
at Toronto, and visited the Royal Museum there. The geological and mineralological halls are on the top floors. The principal light comes through ground glass giving a beautiful diffused light. The glass cases show no signs of reflected light. Every specimen, stands out distinctly, as if laid on a table. They had mounted the mosasaur skeleton I sold Professor Parks some years before. The only large vertebrate on exlibition.

We were anxious to make a trip by water and pressed on to Port McNickles, where we took the steamer Keetewin and slept that night in state rooms instead of Pullman berths, as had been so common with us of late. We woke next morning in the narrow stream between Lake Huron and Superior. The scenery was grand and impressive, the shore lines clothed with second growth timber. We passed freighters hauling ten thousand tons of coal to the west, and the same amount of iron-ore to the eastern smelters. The channel was marked by floating buoys, each one carrying a light that was intermittent, as fast as it went out, it was lighted again by two permanent lights below. Carbide is used to produce the main light, and to keep the others going. There were also lighthouses at intervals, built in the water on strong cement bases. This passage way of the ships is as well lighted at nights, as the streets of a city. We thought the boat ride more enjoyable than the monotonous train; and we enjoyed the sensation of being lifted into 
the mighty Superior by the Soo Locks. Then our captain threaded his way far from the shore line through the reaches of this great inland sea. Towards night a dense fog rose. Our siren sounded the alarm every few moments, and on either side, before and behind, other fog whistles, too, kept up the refrain "Look out! Look out! Danger! Danger!" We soon got used to the music and were lulled to sleep in our narrow staterooms. We slept in peace, and the next morning the sun rose clear, and scattered his brilliant rays of light over the headlands of the mountains back of Port Arthur, lighting up, too, the grain elevators and pretty town.

On the seventh of June we drove our team to "Happy Jack Ferry," all ready for another campaign.

Of all the strange dinosaurs we found in our hunts for big game in the Red Deer canyon nothing, I think, exceeded the plated dinosaurs in wonderful characters. The first I ever found, I mention in the Proceedings of the Kansas Academy of Science for 1908 on page 257. "Last February, Barnum Brown of the American Museum of Natural History staff, published a description for the first time of his armoured dinosaur which he named Anchylosaurus mag. niventris. It was discovered on Hell Creek, Montana, in 1905 by the American Museum Expedition. It represents he says a group of Stego- 


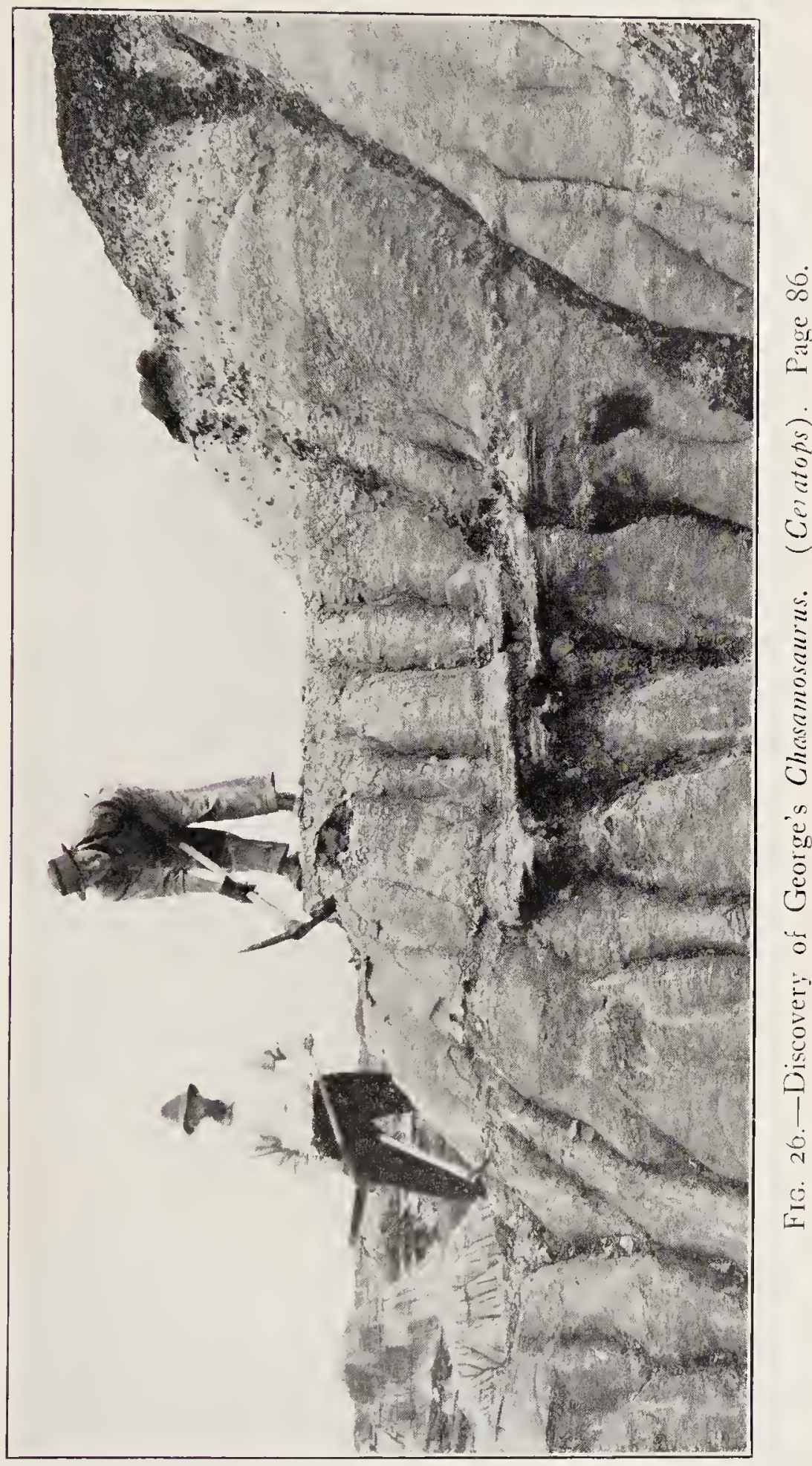




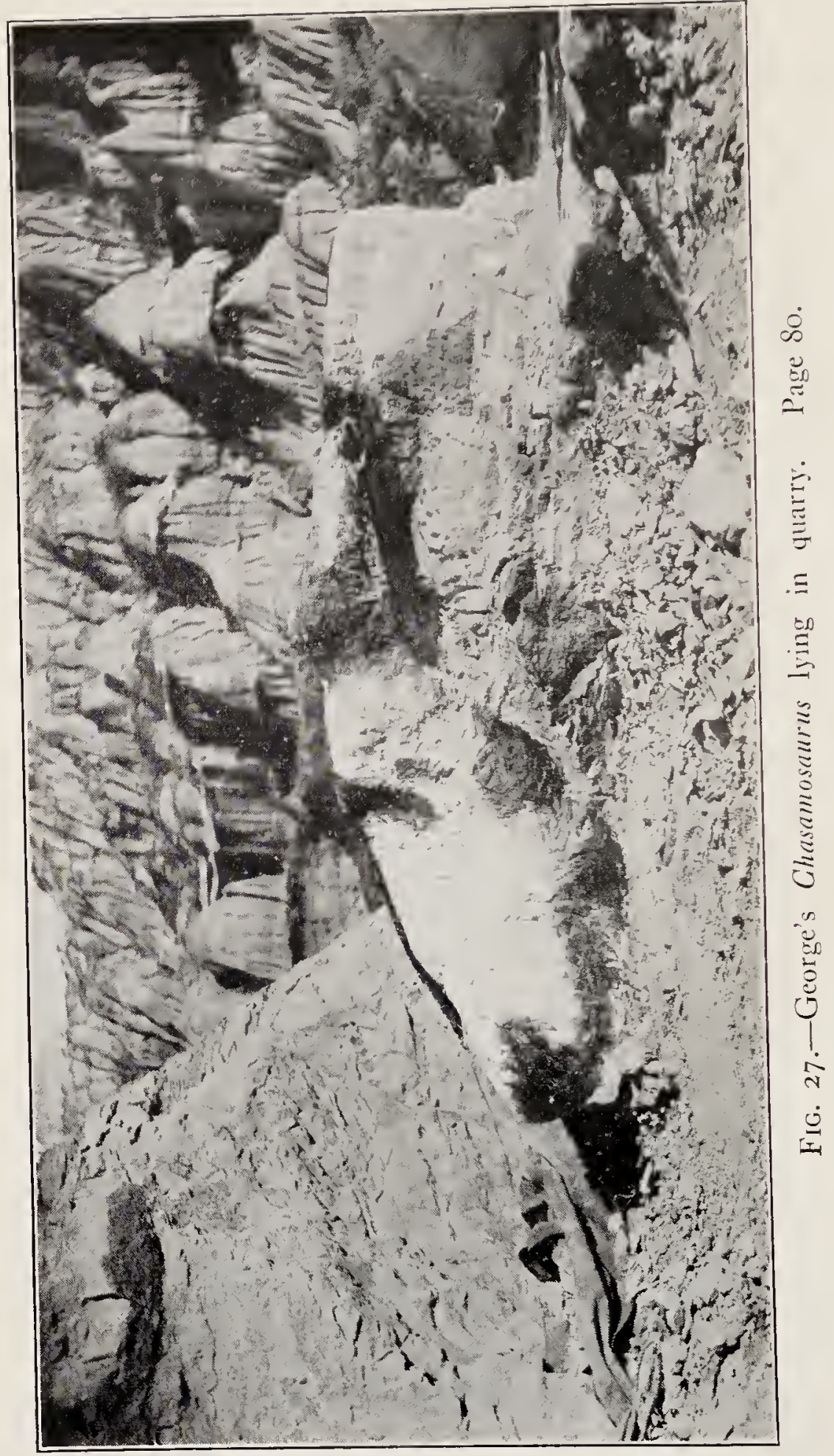




\section{Plated Dinosaurs}

sauria characteristic of the late Cretaceous of this country.

In 1905 while conducting an expedition to the Kansas chalk I discovered the broken up skeleton of what I considered a large new sea tortoise with an ossified carapace, it attracted my attention and I knew it must be new, but as it was badly weathered, and detached from its matrix, conclnded it could not be used and left it there. Later, my son George brought into camp, a few miles from Hackber'y Creek, where I found my specimen, some peculiar plates, like the ones already mentioned. But as I had no knowledge of Barnum Brown's discovery I concluded they were neurals of a new turtle. These I sent to Dr. Weiland for description. Last month I was his guest at Yale Unirersity museum. He asked me why I thought it a new turtle. After giving my reasons, he told me they were new enough, but these plates were of an armored dinosaur. Later through George's efforts, I secured the skeleton I found the year before. I went over the mass of fragments and separated the armor, and found the entire skeleton was covered with a completely cossified dermal covering, in most beautiful patterns, the larger scutes were diamond-shaped, with round angles, with elevated keel down the center, the interspaces filled with small plates of various forms. This is the second instance of remains of a dinosaur being found in the Kansas chalk, showing that the bones of swamp and land 
saurians in shore, drifted out to sea. The other individual was a duck-billed dinosaur called by Professor Leidy, Hadrosaurus; but later Prof. Marsh identified it as belonging to his genus Claosaurus of the Lance Beds of Wyoming. As far as I know no other specimen of dinosaurs have been found in the chalk of Kansas. Strange indeed then that we find enough of the skeleton of a dinosaur for identification. Separated from the dinosaur beds of Wyoming by at least 10,000 feet of strata and in time a couple of million years at least, showing that we do not as yet know the time and space occupied by dinosaurs on this continent.

Later still in the Belly River Beds of the Dead Lodge Canyon, in 1914, George found the skeleton of a similar species. Mr. Lambe gives it the name of Euoplocephalus; no complete skeleton have been found of this strange dinosaur except in the Belly River Series, though a fine skull and other bones were found by Brown, in the Edmonton beds of the Red Deer river, similar to his Lance Creek genus in Montana. Last year, 1915, both Charlie and I found some fine material near the mouth of Dead Lodge Canyon and at Loveland Ferry twelve miles below. As already mentioned, George found the best specimen we have obtained. From all three (and the tail club I secured in 1914), we get a very good idea of this peculiar reptile. One thing I learned from the specimen is, that the plates are not co-ossified as 
I had supposed from ny study of the Clalk specimen, but that between the larger plates, are yuite small ones arranged like chain armor so as to allow the body to move in any direction, unhindered by the hatry armor; these small ossified scutes are so beveled as to move on themselves, that is, they are imbricated, while the others are not, and are arranged like mosaic work in a parement. Mr. Brown was the first to publish a figure of a skull of his Edmonton species. The skull itself has the bony skin plates anchylosed to it. Mrr. Brown tells me that even the eyes are protected by sliding shutters that drop down over them in time of danger. The horned beak is rounded in frout and the few teeth behind seem of little functional value. The beak however, was a powerful organ for digging up roots, or nipping off foliage. The head was rery small compared to the immense body. The great ribs over five feet long, and hoop-shaped, wiving the body a round, barrel-like form. The heary bony armor of huge plates, some of them weighed in their fossil form twenty-five pounds or more; though light and spongy in life. Many of these plates were harder and denser bone than the ones mentioned before, keeled down the center. The small nodules of bone fitted in between the plates and were so beveled as to move on each other like chain armor. The entire body was thus covered and protected. Unfortunately no complete skeleton has been found with every dermal 
plate in position. Of course I am not familiar with the many skeletons of this form Mr. Brown has discovered and have been looking a long time for a Memoir describing these interesting forms. The great desideratum is to find one of these wonderful reptiles with all the armor in place; just as the skin was found in the "Dinosaur Mummy" and the Senckenberg specimens of the crested duck-bills. However we already know there was an anchylosed necklace back of the head and that the end of the tail was club-like. I secured several of these clubs.

Let us go back to the time when the Belly River rocks were forming in the bottom of the lake. It is spring; every thing throbs with life. The sap is surging through the trees arrayed in their brightest tints, the ground below, is carpeted with flowers in endless variety and hue; there is a clump of evergreens, and here one of poplars, while in the distance are, figs, magnolias, and a wealth of other trees, all adding beauty to the scene. Along the lake shore, dense masses of horse-tail rushes, moss and long coarse grass cast waving shadows. On the quiet bays vast masses of water lillies, waft their incense on the air, and delight our senses. Above us the swinging redwood branches shut out the direct rays of the sun which falls as if filtered through the stained windows of some great cathedral. Let us creep along to the second bench that overlooks the jungle of vegetation, that spreads out in great 
meadows to the lake itself. See that thicket! Let us approach it quietly and peep through as it opens beyond in a park in the forest. Such a sight is rarely offered to human eyes. See that reptile over twenty feet in length, a great round body twenty feet in circumference, a short stubby tail. A small horse-shoe shaped head with horn sheathed jaws, small but strong. Back of the head, are necklaces of bony scutes, keeled down the center separated along their edges, by small nodules of bone, that move on each other giving a mobility to the skin even though the animal is as heavily armored as a fighting automobile of the great European war of today. The tail, too, is covered with enormous bony plates, though light and porous, compared with the dense bony-plates covering the body; the end is heary and blunt, club-like in fact. His pillarlike limbs are short and robust, to support such a body. The belly almost reaches the ground, the heavy tail drags behind. He moves along sluggishly, compared with the lighter horned dinosaurs and carnivores. See how readily he beats a passage way through the underbrush that borders the woods, and emerges into the open park. We notice his huge proportions and unique appearance. He is completely armored and sluggish in his gait. It does not seem that even the fierce Gorgosaurus of the everglades, the tyrant of this peaceful woods would find a single vulnerable place open to attack. More likely if 
lie made the attempt he would simply whet his teeth on the glistening armor, that protected him in vain. He might perhaps break off a tooth or two, before he learned his task was a thankless one. WVe can even imagine that he would be in danger himself if he carelessly approached too near the tail. For a blow from the powerful club at the end would break in his ribs.

As the strange saurian passes us we notice the large trail he makes through the bushes as he mores on down into the meadow-like flat for his breakfast.

See! Ont there on the lake is a plesiosaur fish. ing, he evidently came up the rivel (that heads in the bottom of the lake), from the Pierre ocean not many miles away. Te know the lake is full of sturgeon and gar-pike. He has a beautiful head poised on a long swan-like neck, a broad heary bods, and a rers short tail. We hare seen them before along the shores of the old Cretace. ous ocean. As his bones were common in the chalk of Kansas. Within human history white whales have come up the St. Lawrence river from the Atlantic Ocean. They have one in the Victoria Memorial Museum at Ottawa, that made the trip once, but nerer returned, and they dug his bones out of the flood plain of the river. 


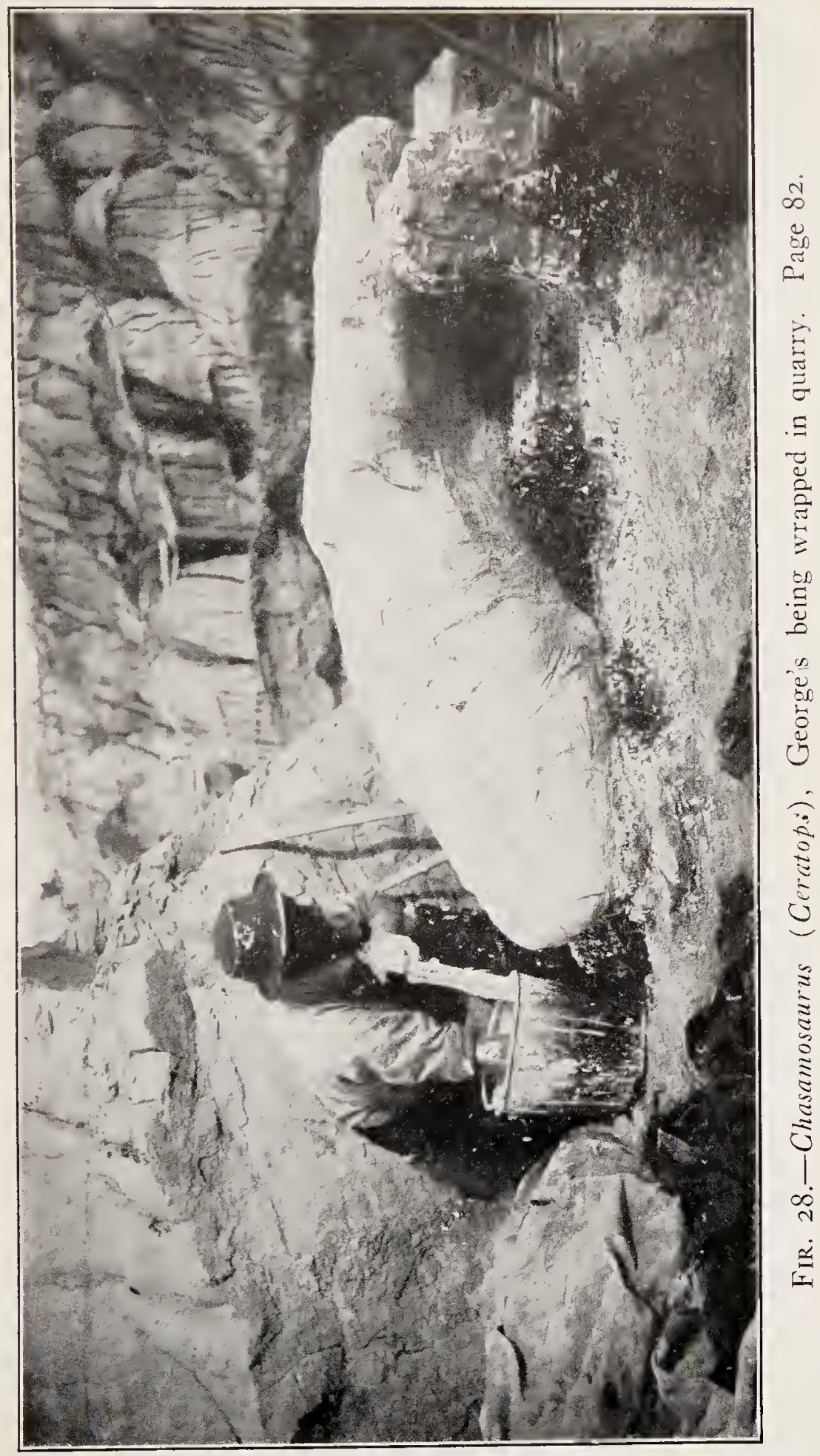




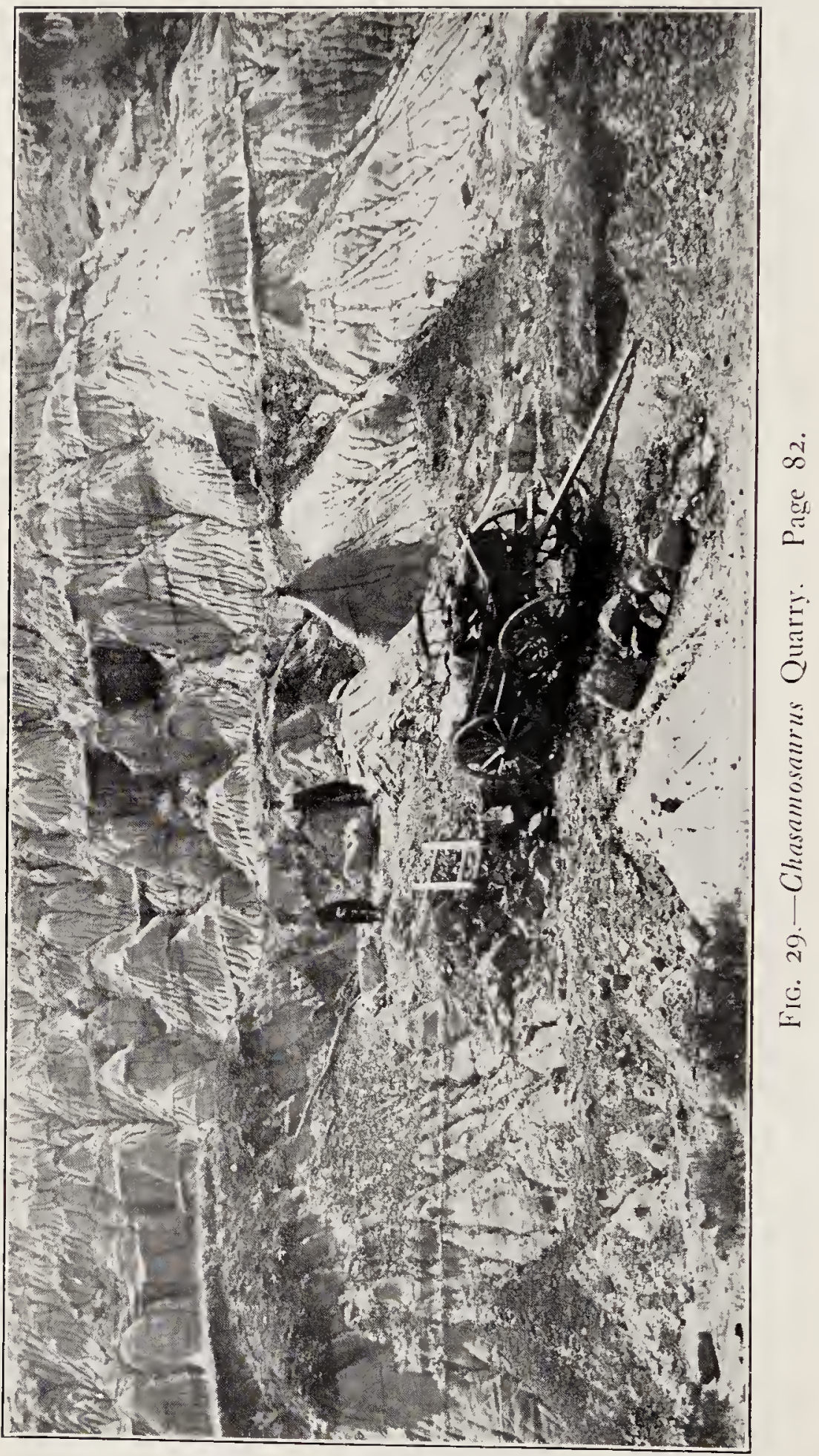




\section{CHAPTER VII}

THE GREAT SPIKED DINOSAUR OF DHAD TOODE CANYON

On the 17th of September, 1913, George and I loaded our row boat, and motor boat with our tent, blankets, and cooking utensils and tools, and start down the river in search of a new camp. In the photograph of the scene, Levi is standing on deck of the flat boat and bids us good-bye and good luck. George is driving the motor and I sit in the center of the boat. Notice the row boat we trail behind, is heavily loaded. This was the hardest trip we ever made with the motor boat, as the water was low, we were constantly getting stuck on a sand bar. They extended often across the river. George was one to suffer, as he was the only one of the two that had the strength to pull it across into deeper water. When we stuck fast, I got in the row boat and paddled over to a deeper hole, and went a fishing, while he struggled with his boat. It was a terrible experience, but well bought, as he learned what the Red Deer river was in low water, and when he went on it again, in 1915 he built himself a motor boat that would float in five or six inches of water. While mine required eighteen inches to float it. At last with George nearly exhausted, we pulled 
into shore at "Happy Jack Ferry, twelve miles below Steveville. We pitched our tent on the southern side of the river. On the 19 th of September, I made the discovery of the strange spiked dinosaur, called by Mr. Lambe Styracosaurus. The ground was wet with repeated showers. The fossil beds are not safe then, as one slips as if walking on soft soap. There is much clay in all the rocks; in fact more than half of them are made up of clay, interlaid with silver gray sandstone, also containing much clay. However, I could not be idle about camp and made the attempt to get in the bad lands walking up the bed of a long coulee that was filled with boulders. I got to where it was extremely difficult, as the bed was narrow and crooked. So I attempted to scale a steep slope and got up a hundred feet; that brought me over a perpendicular precipice, while above was a heary bed of clay. I knew if I could get over the clas, I would be all right, as I would then be on top of a spur from the prairie, wide enough for me to walk on. Howerer, the minute I would drive my pick into the clay to hold me from slipping, it would break loose and let me slip back to a narrow ledge above the cliff. I attempted to cut a path with the same result, and as I saw I could not go up, I resolved to go down the way I had gone up. This I found was impossible; for if I sat down I would slide and be hurled over the precipice. I then got frightened and attacked the steep clay slope again, with 
the same results. I realized then if I could not climb over when in my ordinary condition, certainly could not when frightened. I therefore sat down on the narrow ledge until I recovered my composure. And by careful searching the steep slope I had come up, I found a little ditch with small bushes growing in it. It was washed clean of mud, and I got a foothold in it, and gradually let myself down into the bed of the coulee. I did not attempt to leave this again and at last reached the head. Many other ravines header near by, and in going over to one of them I saw in the steep slope of a narrow gorge, in gray sandstone, the skull that is rather poorly shown in the picture. It was 200 feet below the prairie, and it required a great deal of labor to collect and load it in the wagon. It was first packed securely in a box, after it had been carefully wrapped in burlap dipped in plaster, and secured with strong poles to hold it together. A road was cut in the face of the cliff, and our faithful team hauled the box weighing about nine hundred pounds, out of the rarine; they often fell down and cut themselves, but they scrambled up the narrow road with their burden fastened to a sled. When they got to the level prairie, the boys let the hind wheels into the ground to the hubs and rolled the box in. The skull was partially prepared by me the next winter as shown in the photograph which gives a top view of it. This is one of the many remarkable forms that were so abundant during 
the Mid-Cretaceous time. The skull was over six feet in length, with a great hor'n core over the center of the nose, twenty-four inches high, and six inches in diameter at the base. But stranger than all, six horn-cores radiating from the crest hehind where it is four and a half feet wide. The central horn-cores are the largest, twenty-two inches long, the next pair twenty, and the outermost fourteen inches wide. All these horn-cores were covered in life with hor'n, lengthening them materially. The crest, from between the center of the eyes horns is four feet long, while the portion of the skull in front is only two feet. The narpow bar that carries the spikes behind, is narlow and heary, thinned down with the central and marginal bars to form large openings. The skull too, as in Chasamosaurus is dug out into cares. Only a thin septum of bone separate the liain case from the central air chambers, there were no attached orbital horns, but cup-like depressions, as if the horns had dropped out, having been ossified from a separate center. All the bones of the skull show vascular grooves, as if the entire skull was sheathed in horn making an impenetratable shield. In the old restoration of Triccratops the neck is enlarged to fasten securely into the neck-frill or crest. To me such an idea is absolutely absurd. The round occipital condyle enabled the animal to bend the head in any direction at the atlas vertebra, as in the four limbed mammals of today, that have to put 


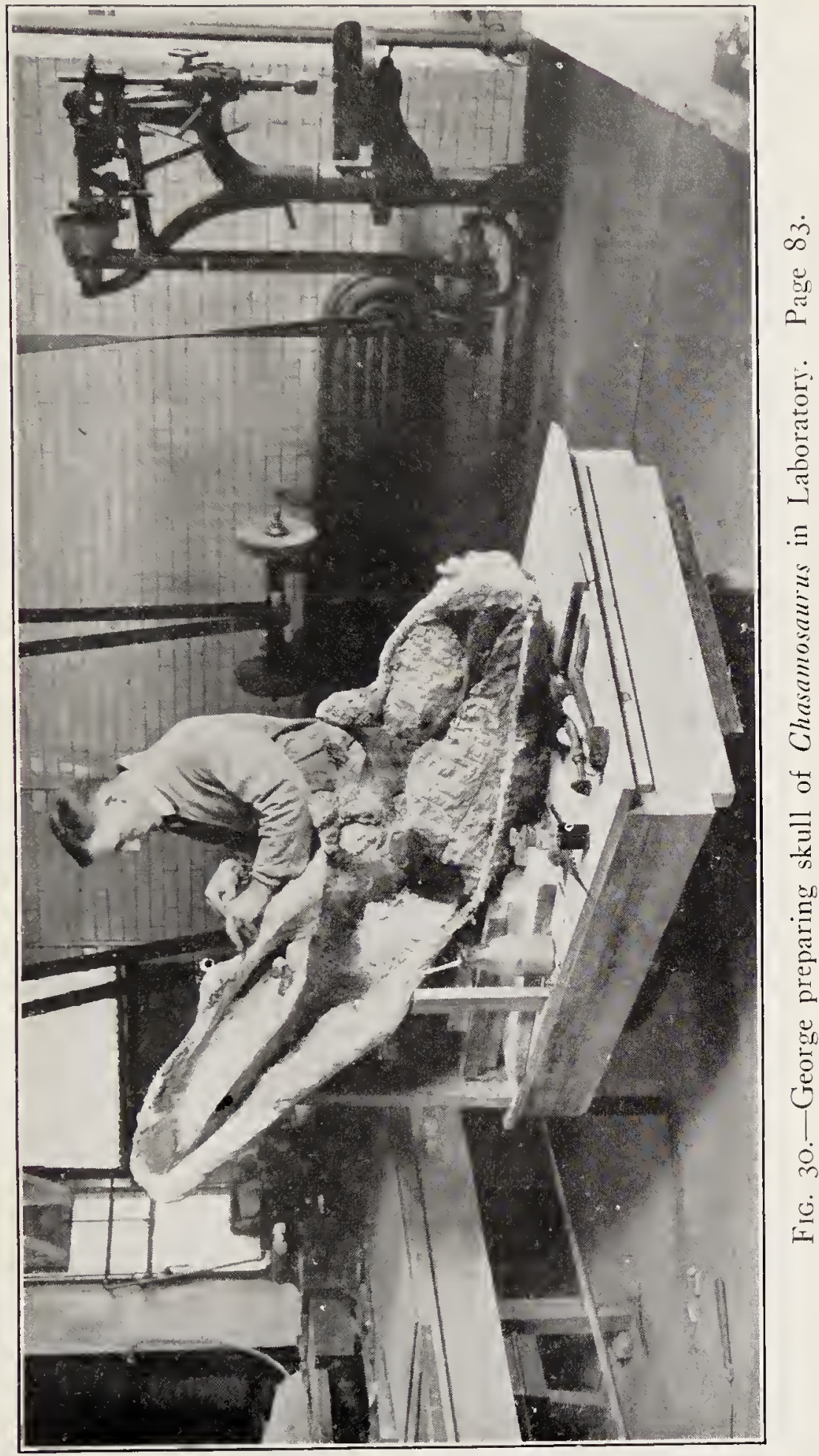




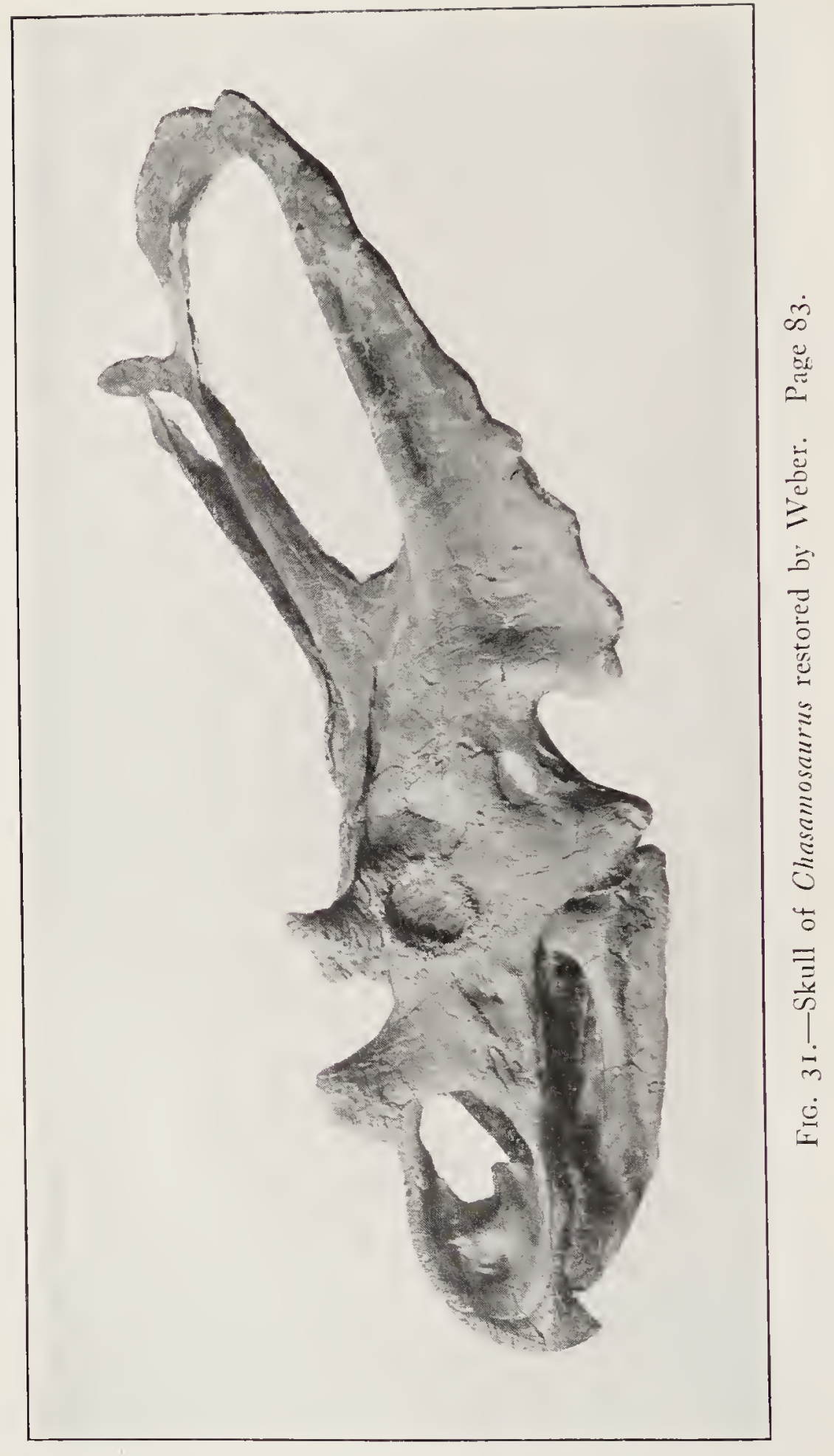


down their heads to eat or drink. If the shield were fastened to the neck the reptile would have to lie down to feed and drink or go into the water, unless there was a similar arrangement between the body and neck vertebrae. In the case of Chasamosaurus or Ceratops, where the crest reaches to the hips, the socket would be in front of the hips, so when feeding on rushes he would have to kneel on his front limbs and bend at the hips. A most remarkable arrangement. Then. too, it would be of little use for a shield of defense against his subtle carniverous enemy. No, I am sure the old idea in regard to the neck frill is a mistake and I ask you to please go back with me and I will show you the reptile alive.

We find ourselves sitting in the shade of a giant red wood, for the sun is up. The ocean far to the south, out of sight reveals its presence in the salty refreshing air that reaches us. The land before us has been slowly rising at the rate of deposition, and is but little above tide water. Great meadows on the swampy flood-plain of a large lake lie a few feet below the bench, that is covered with a dense forest. Nature has a wonderful work shop for the Creator, one continual plant, for turning out perfect living forms endowed with life and power. Let us go down toward the jungle of horse-tails, other rushes, and high grass, that waves in the passing breeze. On the very margin of the lake itself from the white sandy beach, we pick up teeth, and scattered 
bones, and mussel shells. There is plenty of drift wood too, lying in heaps, left there by the last flood. We wander on towards the plain. Hark! don't you hear a noise in the thick vegetation as if a heavy reptile was cropping his molning fare? For reptile it must be, as only diminutive marsupial-like mammals live at this time. If you will follow me, we will see. So, without further ado, we walk into the rank vegetation, and parting it, look down a narrow path along which a spiked dinosaur is feeding. He is unconscious of our presence and is feeding towards us. His powerful limbs of equal length, arc sunk deep in the moist earth. His head is in plain sight, and the crest stands up when he bent it, to crop off a mouthful of succulent herbage with his heavy beak, sheathed in horn. This he shears with his beveled teeth behind, very much like the mechanism of an old fashioned hay cutter.

The teeth are double rooted, and in magazines like those of the duck-billed dinosaurs, though not as numerous. The great horn is black and polished, full three feet long, like the sharp spear point in the shield of thick buffalo hide of a Philippian Warrior. The great spikes stand out from the top of the crest when he lowers his head. Thus fully armored he can force a passage way through the thickest vegetation, beating it down beneath his feet. There are four hoofed toes on each front foot, and three behind. The large 


\section{The Great Spiked Dinosaur}

restless eyes are butressed over with bone to protect them from his enemy, Gorgosaums, the tyrant of the everglades, and from the dense vegetation through which he beats his way. As he passes us and stops to feed again, thus raising his shield in the air, we get a splendid view of his scaled body, with its color's harmoniously blended with the vegetation by which he is surrounded. They are much like those already seen in Ceratops or Lambe's Chasamosaurus He seems satisfied with his breakfast, as he lifts his head out of the rush covered soil. As a narrow neck of land tongues out into the plain from the first bench, it seems that he is headed to cross it into the jungle beyond. As he climbs out of the plain, on to solid ground under the forest trees, we notice he is ten feet in length to the drop of the tail, which is short, and he drags the end on the ground. He stands at least six feet in height. As we follow his moist spoor, we soon enter a small park covered with grass and flowers. Suddenly, we hear the most blood curdling hiss, that chills the marrow in our veins. What can it mean? The Styracosaurus knows for he is instantly alert, lifting his head in the direction of the sound, he drops it again, and stands at bay. With another blood curdling hiss, a gigantic carnivore leaps into view, from a trail we were following. Our spiked dinosaur stands rigid as if cast in bronze, with the great nasal horn pointed towards his dreaded foe, and the spikes frown- 
ing above, and protecting the vital organs, the great cat-like reptile crawls stealthily forward. Don't fear friends to watch the combat. It is very terrible to see a blood thirsty tyrant slack his thirst in the blood of his victim. He attempts to find a vulnerable spot to strike with his powerful claw-armed hind foot, the claws of hardened horn, sharp and recurved, each a foot in length and spreading over half a square yard of surface. Or he would like to seize the thinly covered abdominal walls, with his horrid teeth, lance-like that fill the dentary and maxilary bones of the lower and upper jaws, that are nearly three feet in length. With a gape of the mouth of nearly two feet, the red gums, roof and floor of the mouth, with the great forked tongue, present a terrifing appearance. But the spiked lizard is on guard, and when his enemy makes a sudden dash at him, he presents his impregnable head. In spite of his bulk, being much heavier than the carnivore, he seems to revolve on a pivot, and the shield is where the Gorgosaur attempts to strike. The instinct of self-defense is ever present, in time of danger. Sometimes the herbivore makes a sudden dash, and trys to horn the agile foe, or with open mouth tries to bring his vise-like beak together in his enemies flesh. We watch the combat with bated breath.

The seven horned brute is too much for the tiger of the glades; so, thoroughly exhausted at last, he creeps off a side path to hunt an easier 


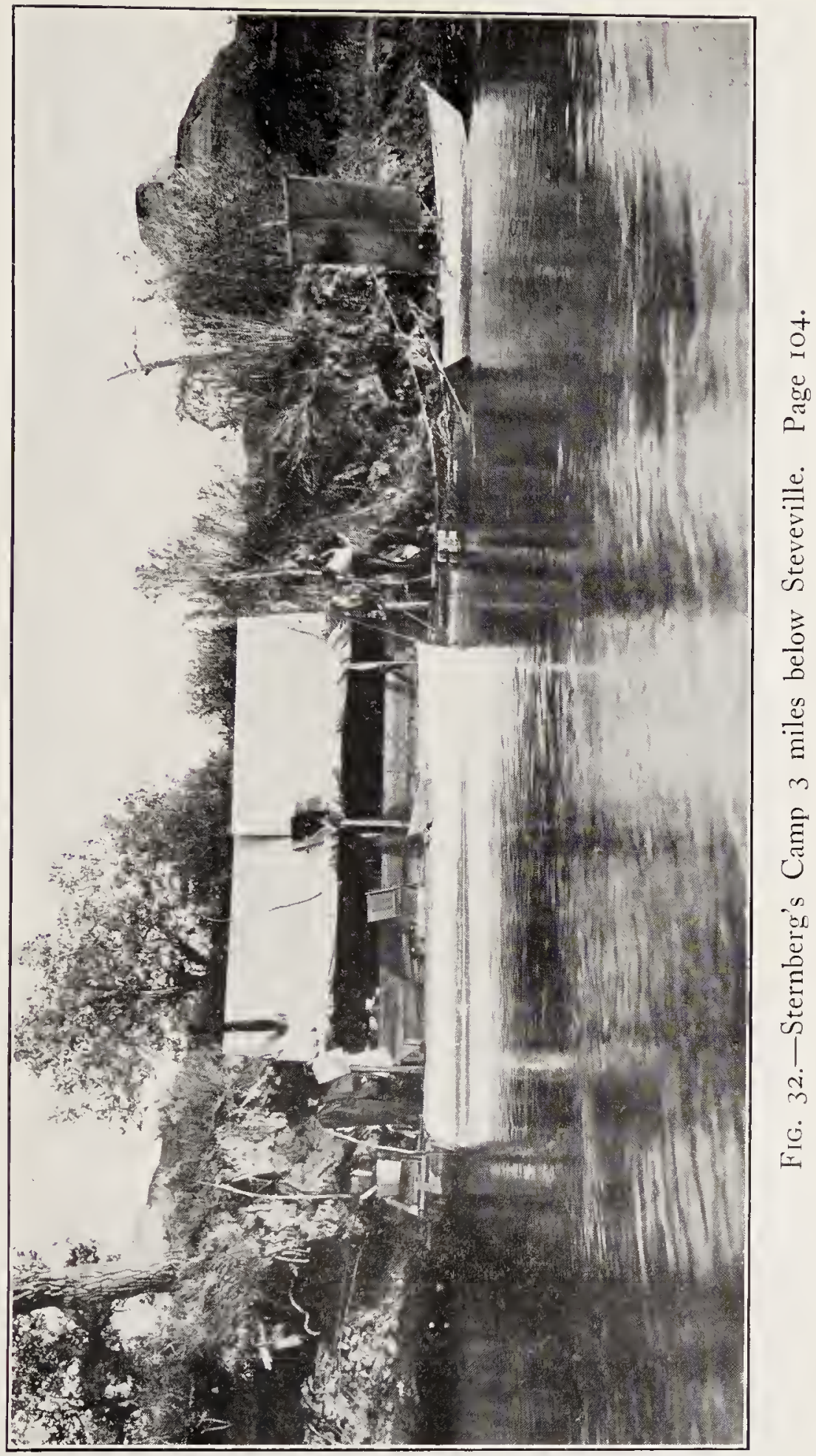




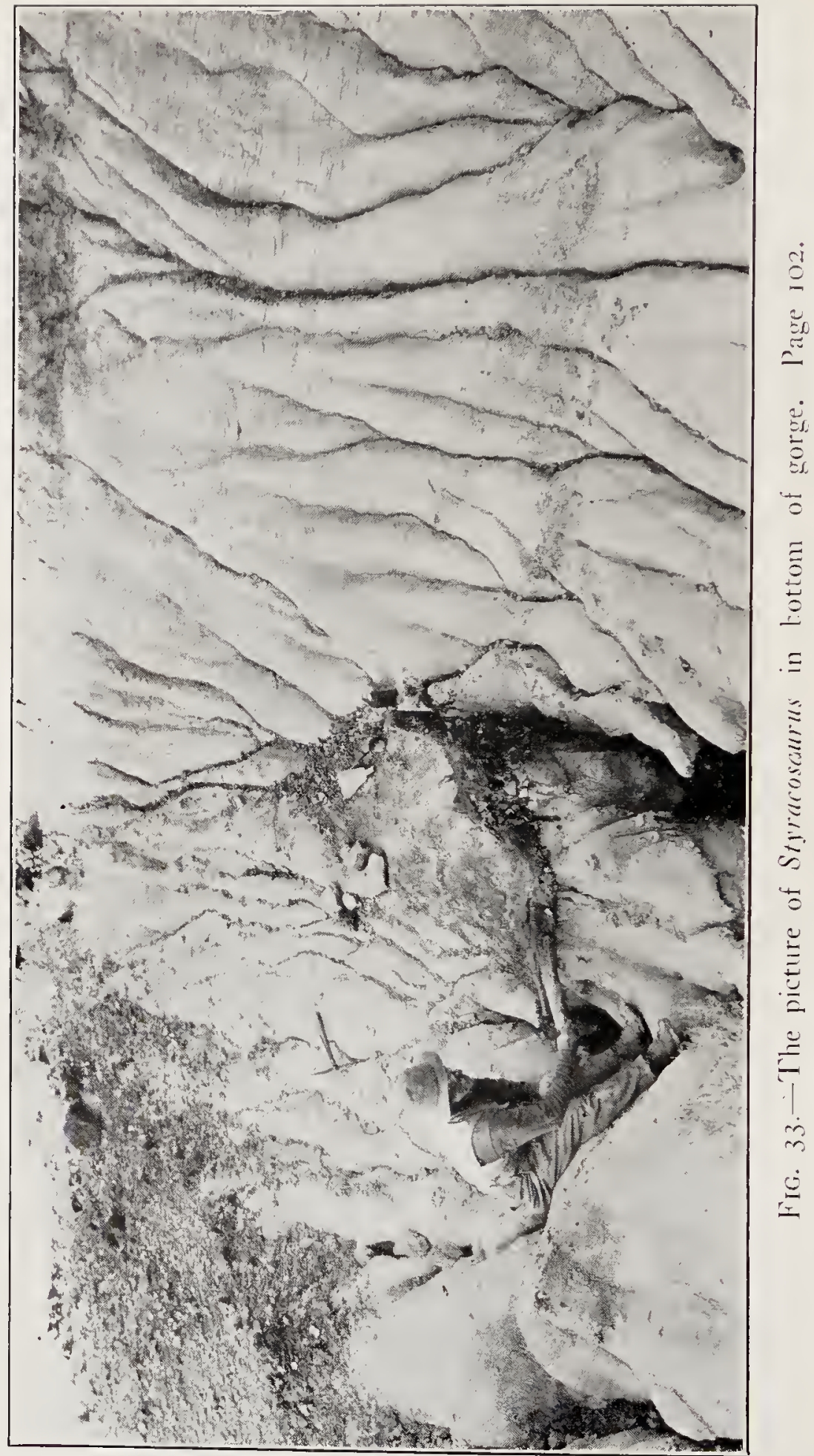


prey. While our Styrocosaurus humbers off into dense foliage of the low lying plain.

"The Dead Lodge Canyon" below "Happy Jack Ferry," some thirty mites north of Brooks, Alberta, and but six miles from the new line from Swift Current to Bassano, a short cut of the Central Pacific Railway, is one of the most remarkable gorges on the continent. Not only because it is the old burial ground of many forms of the dinosaurs that have passed out of exist. ence, learing no descendents, but on account of its scenic beauty. The silvery grey sandstones with their darker bands of clay, is interstratified with a chocolate colored bed near the top, rich in lignitic shales of an almost black color. The black streak can be traced for miles, and in some places derelops into a bed of soft coal, that is mined by the farmers. The canyon is but little over a mile wide, and about five hundred feet deep, the upper reaches being composed of dark marine shales, called the Pierre liere, but the same beds in the Judith River country of Montana are called Bear Paw shales. 


\section{On the Judith River, Montana}

\section{CHAPTER VIII}

ON A TRIP TO THE JUDITH RIVER, MONTANA

Under orders from the Director of the Geological Survey of Canada, Charlie and I left Brooks, Alberta, on an expedition to Montana, for the purpose of studying the sequence of the rocks there, and to compare them with those of Canada. Mr. D. B. Dowling, a Geologist of the Survey, joined us at Coutts to do the stratigraphical work. I cannot help, in this connection remarking, he was in addition to his geological knowledge, the most genial companion I have ever been associated with in camp, excepting, of course, that prince of good fellows, the late Professor E. D. Cope of Philadelphia, with whom I made the same trip in 1876 . A complete story of that expedition is recorded in "The Life of a Fossil Hunter." At Coutts Mr. Dowling and I went out to some rocks exposed south of town which appear to be the true Eagle sandstone of Weed. A compact greyish and reddish sandstone with strong lines of cross bedding. These lines are also lines of cleavage. Above are some seventy feet of the Belly River Series, clays, and fluted sandstones. On July 2nd we stopped at New Park Hotel, at Great Falls, Montana. Not far from the depot; while here we 


\section{On the Judith River, Montana}

took a trolly ride out to the great smelter near the Falls of the Missouri, three miles east. The works cover acres of ground and the smokestack is said to be the largest in the world. The falls here were low and below was a series of rapids. Whenever we chanced to catch a view of the Missouri, on our trip east by the Great Northern we could see the river for many miles, full of falls and rapids. At Benton I saw no sign of old Fort Benton I visited with Professor Cope in 1876. We noticed aloug the track the typical Fort Benton shales, dark colored below, yellowish shales above, while unconformable masses of the ancient river bed lined the faces of bluff and ridge or helped to fill the old ravines, composed of unstratified yellowish clays, sand and gravel. The narrow flood plain of the river is fringed with cottonwoods and poplars, with birch and willow thickets, underbrush of wild roses, bullberries, etc., with the ubiquitous sage brush everywhere. The Northern Pacific passes through a rolling prairie north of the Bear Paw Mountains. In 1876 the only wagon road here was south of the mountains and it started at Fort Benton the head of navigation, and ended at Cow Island, 120 miles east.

I noticed the farmers irrigating their gardens and alfalfa fields with water drawn from the Missouri with buckets attached to overshot wheels, on their turning the water was spilled into a trough connected with the reservoir. It 
was carried from there, over the fields. We got off the train at Iin'springs, went to the Spokan Hotel, and registered in the bar room, where they had the office at one end of the bar. I thought that was going it some, excuse the slang. and that Montana needed "Total Prohibition" pretty hadly. The dining room opened off the bar. At the livery stable we hired a team and democrat wagon for two weeks for \$50. In the afternoon we drove out in a buggy to the coal mine eight miles southeast. Here the light yellowish sandstones with harder parts were filled with thin circular concretions as flat as a panrake. The rein of coal is about fire feet thick at an angle of about 16 degrees. On either side are narrow beds of yellow sandstone dipping in various directions, the strike being paralell with the Bear Paw Mountains not far off to the south. Between the sandstone layers is a dike of volcanic trap, black, and fine grained, pushed up through the strata so it forms a hog back elevation above them. There are also beds of light colored shales, with seams of iron stone between.

On July 3rd, 1914, we drove to a flat near the site of a reservoir, now dry, and stopper at a farmer's. We had skirted the eastern limits of the Bear Paw Mountains, passed through a rolling prairie, crossed Eagle Creek, where a fine flow of water, full of little fishes, runs over gravel and sand towards the Missouri river. As we journeyed south we saw evidence of vulcan- 


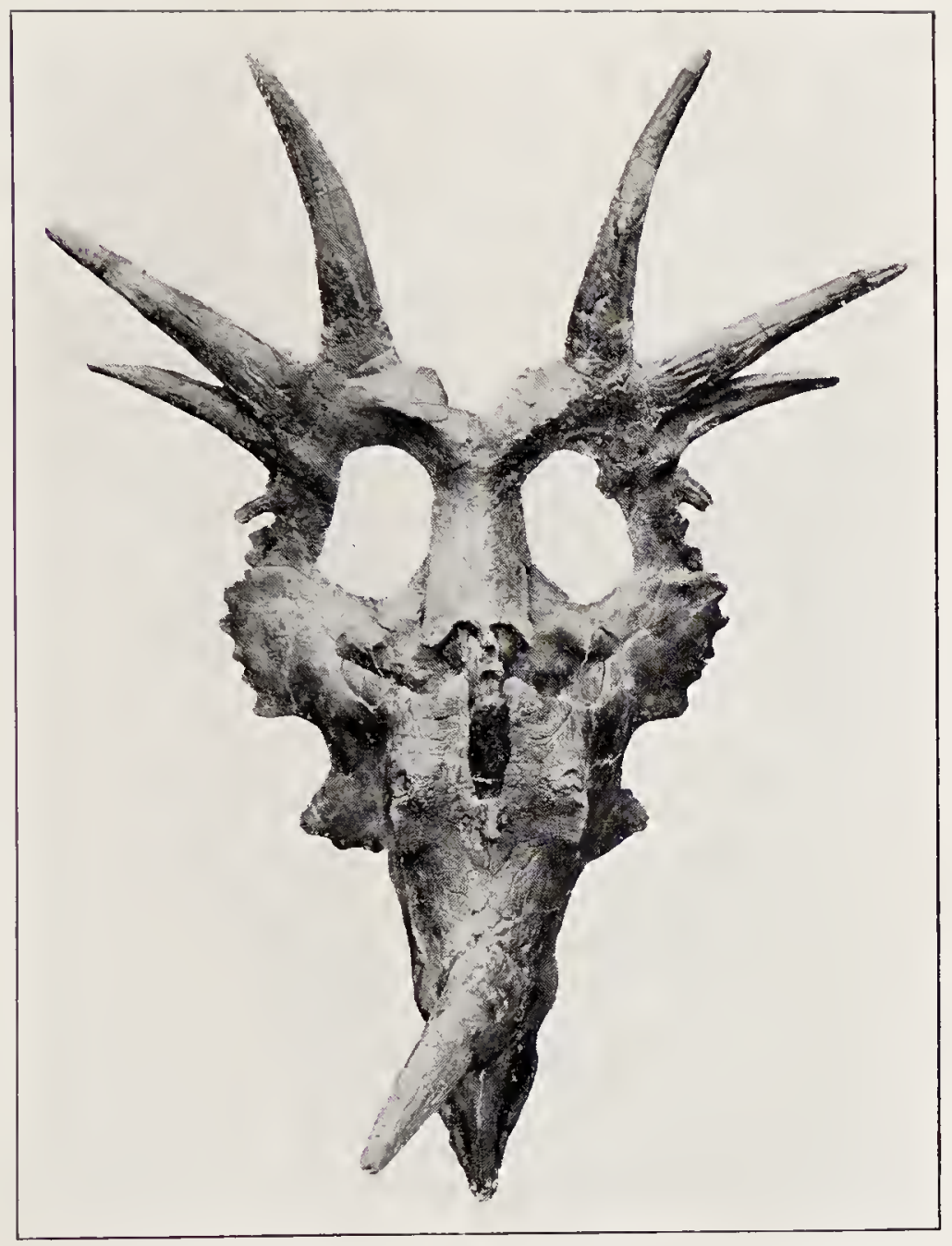

Fig. 34-- Top view of Styracosaurur as prepared by Charles H. Sternberg. Page 104. 


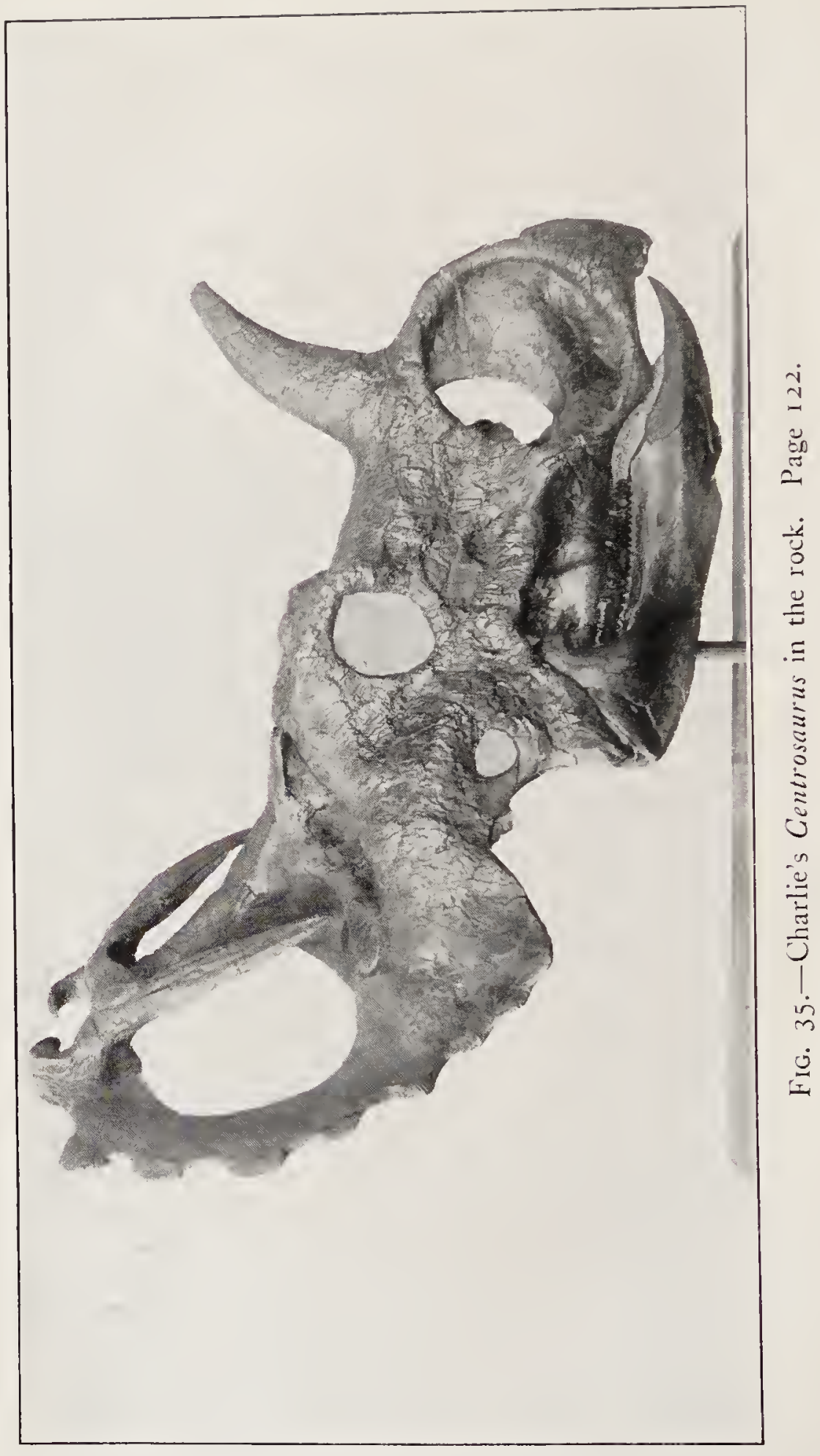


ism in a narrow strip of naked rock that had been shoved up in a wedge shaped mass through the grass of the prairie.

On the Fourth of July we reached the ferry below the mouth of the Judith River and took dinner at the ranch called Judith P. O. The company own their own store, bunk-house, cookhonse and stables, and have in a great crop of alfalfa. They also own the ferry, and owing to high water, the approach from the north was cut out, and we had to get our horses on board the best way we could, and then pull on the wagon by man power. We were kindly entertained at Judith. In the afternoon we drove up to Dog Creek, where Professor Cope made his famous expedition in 1876. The effects of rulcanism are seen on every side. The views I show, fully illustrate this phase in the earth's crust. The picture with the white sandstone tipped up to the left, represents the Eagle Sandstone with the Claggett Shales to the right. These shales should be on top of the Eagle Sandstone. They closely resemble the Pierre shales, below the Edmonton beds in Alberta, and contain the same baculites, ammonites and plesiosaurs, evidently. The foreground of the picture, shows part of the narrow Dog Creek valley corered with grass and sagebrush, with a few cottonwoods in a bend of the creek. On the opposite, or east side of the creek, we found a trail leading up to the divide 


\section{On the Judith River, Montana}

over the Claggett shales. 'These, Professor Cope called Fort Pierre.

On July 24, 1914, a paper of mine appeared in "Science," in which I undertook to show that the Dog Creek beds were equal to the Edmonton Beds of Alberta. And those at Cow Island, should be correlated with the Belly River Beds of Alberta, with the Pierre shales between. I took Professor Cope's view. He believed the Judith River Beds were above the Pierre and Fox Hills Group of the Cretaceous and called them "The Judith River Beds" or "Cretaceous No. 6." After two seasons of exploration of the Belly river series in Dead Lodge Canyon, of Red Deer River Alberta, in connection with our study of the Dog Creek and Cow Islands rocks I was obliged to accept the conclusions of Hatcher and Stanton, in their fine work on "The Geology and Paleontology of the Judith River Beds." The whole series here, and on Red Deer are without doubt Ft. Pierre. The Judith River and Belly Rivel beds were local elerations abore the Pierre Ocean. We actually added to the mass of evidence to this effect, by the discovery of sixty feet of Bear Paw Shale on top of the Judith River beds at Taffy Creek, a branch of Dog Creek to the east. We also learned how easy it was for Hayden, and Cope to make the mistakes they did in their hurried survey of the bad lands. I walked miles over both Bear Paw and Claggett shales, and found it difficult to tell them 


\section{On the Judith River, Montana}

apart. Vulcanism has often lifted the older beds higher than the more recent ones. The what seemed to us true, the ammonites, baculites and plesiosaurs, were the same in the two marine beds, though separated by the fresh water Judith River series, which is of the same age as the Belly river beds.

We walked up the steep slope to the divide between the breaks of 'The Missonri river and Dog Creek, this divide is neary 600 feet above the river. Somewhat different from what my memory had told me of these great canyons. I speak of them as being orer a thousand feet deep in "The Life of a Fossil Hunter." In 1876 we had no barometer to take our altitude and my notes were lost in a fire in 1881, it is natural for the mind to exaggerate depth and height as well as level surfaces. However, as we made this trip by moonlight, and through the solemn silence, I was again orercome with awe when I gazed into the stupendous gorges and at the beetling crags that overlooked them. Hour after hour we passed slowly along the trail, often only the narrow ridge between two great canyons, and a balky team might have backed us off into the abyss filled with inky darkness. Only a journey under such conditions and in such a region of utter barreness, can give the reader an idea of the emotions that over-powered me. We made camp about midnight, and the only sign of human habitations we saw, (except a deserted sheep 
ranch), were the fireworks thrown into the sky at Kendall, where the people were celebrating. We made a camp later, on an eastern branch of Dog Creek, called Taffy Creek. We made a thorough study of this region near camp. During our trip up Dog Creek we had made extensive collections of invertebrate fossils from all the different horizons, securing also Myledaphus, and other sharks teeth from the lower Eagle Creek sandstones which, with the Claggett shales, form the lower beds of the Belly River Series of Alberta. On the south side of Taffy below a large timbered hog back upheaval, I found a locality in the Judith rirel bed that is possibly the type locality from which Cope and I secured our collections on that memorable ex. pedition of 1876 , when we found the first of the horned dinosaurs (except loose teeth). A "blow out," as they call it in the west, had exposed along a narrow slope of sandstone, many bones and teeth of horned, plated, duck-billed, carnirelous dinosaurs, with the teeth of Myledaphus, and many broken turtle shells, as well as bones of Campsosauns, scales of ganoid fishes. Exactly like the numberless bonebeds along Dead Dodge Canyon. What delighted me most of all was discovering the nearly complete pelvic girdle, including the footed ischia, proving that these bones belonged to a crested dinosaur like the one we found on Red Deer rirer and was call. ed Stephanosaurus by Lambe and Corythosaur- 
us by Brown. You will notice that we have two names usually for these Belly River species. I try to credit each student as best I may, leaving it with future scientists to decide which nante shonld be retained in American Paleontology. The Edmonton bone-beds, are rery different, resembling flotsam along the line of high tide, and are all deposited in brackish water. These beds like those in Dead Lodge Canyon, were laid down in fresh water. There were very few turtle shells in the Edmonton, here they strew every exposure. Everywhere in this region were two presistent layers of coal on top of the Judith river followed by the Bear Paw Shales. Above the upper rein of coal, is a layer of oyster shells from a few inches to fonr feet thick. In the Bear Paw shales south of camp a mile, Mr. Dowling with the aid of a sheep herder, found a new mosasaur, belonging evidently to the genus Clidastes, as the cherrons were anchylosed to the centra of the rertebrae, and the tail was expanded into a fin. The mandibles with teeth, some fifteen feet of the tail and many dorsal vertebrae were found. We also secured some rery beautiful ammonits and baculites and bones of the plesiosaur Cimoliasaurus. But for the uplift, the stratagraphieal record is quite simple, the puzzling strata tipped in all directions were easily identified under direction of the skilled observer Mr. Dowling. It would be impossible for any one on the 
ground to doubt the sequence of the rocks here, as laid down by Hatcher and Stanton.

We followed the trail I'rofessor Cope first made, when we drove down to Cow Island in 1876, camping at the same spring at Lone Tree for noon. The tree itself is now dead. We camped near our old one on the Missouri, forty miles below Dog Creek, though now we lad a wagon road down through the badlands. On the roac down along the badlands we nerer lost sight of the rocks and always found the Bear Paw shales on top of the Judith River beds, proving that I had been mistaken again, and the Cow Island beds were the same, as those on Dog creek, with no rocks between. The only difference I could see between them was the sculptury approached more closely at Cow Island, those of the beds in the Dead Lodge Canyon.

Two things impressed me strongly, one was the fact of finding an ischium with a footed extremity, closely associated with teeth similar to those Dr. Hayden picked up in this region, and Leidy called Trachodon mirabilis. We found four trachodonts in the Dead Lodge Canyon the most common was the crested one with footed ischia. And not a one of them belonged to the genus Trachodon. Neither have any been described. There can be little doubt therefore that Leidy's Trachodon mirabilis belongs to a dinosaur with either a crested head or the high nosed Gryposaurus of Lambe, or Kritosaurus of Brown. 
Is Trachodon a crested dinosaur? The evidence seems to point that way. Then what is Tracho. don annectens of Marsh and the family name? As Leidy used a tooth that may have belonged to three $\mathrm{or}^{\circ}$ four different genera, it seems the early names from such poor material, rests on shaky foundations. If the paleontologists begin to name only complete skeletons, or $^{\circ}$ nearly complete ones there will be a shaking up of old names and many will go into the discard like so much of human knowledge. Marsh had but lit. tle better foundation for his Ceratops. A couple of horn cores, that might have belonged to any one of half a dozen genera of horned dinosaurs.

We spent two weeks of most delightful exploration in the Judith river country, and my mind was set at rest, in regard to the position the beds occupy in the building up of our continent.

On our return, we thought at one time, we would not be able to recross the Missouri river, a flood had washed away the approaches to the fer'ry boat. Howerer, as necessity is the mother of invention," we hauled our "luggage on board by means of a row boat and dragged our wagon through the mud by man power, the ranchers helping us for the fun and excitement there was in it. Later, another man swam across with our team, and we were ready to go north to our old field in Dead Lodge Canyon, Alberta. This field we reached in safety. 


\section{Another Strange Horned Dinosaur}

\section{CHAP'TER IX}

ANOTHER STRANGE HORNED DINOSAUR

In September, 1913 at the camp from which I discovered the spiked Dinosaur. Mr. Lambe's Styracosaurus. I found above our tent back in the badlands in a perpendicular escarpment, a fine skull of another strange horned dinosaur. Mr. Lamb called it Centrosaurus, while Brown still holds the name Cope gave a similar genus he collected in the Judith River Formation in 1876, namely, Monoclonius, of which genus I discovered two species that were new at that time. This specimen I discovered, was about two hundred feet above the river. The first work was to build a platform around it on which I could stand, so I could work around the specimen. Mr. Lambe, himself, found the type of this genus, which consisted of a neck frill about 1898. In this specimen of mine I found a large part of the skull. It was however, due to Charles M. Sternberg's patient labor, that science is in debt for a perfect skull of this strange reptile. It was found the next year after I found mine, in the Dead Lodge Canyon near its lower extremity. You may think from my description of so many fine specimens that we had an easy job of it. When George found his plated dinosaur, he had 


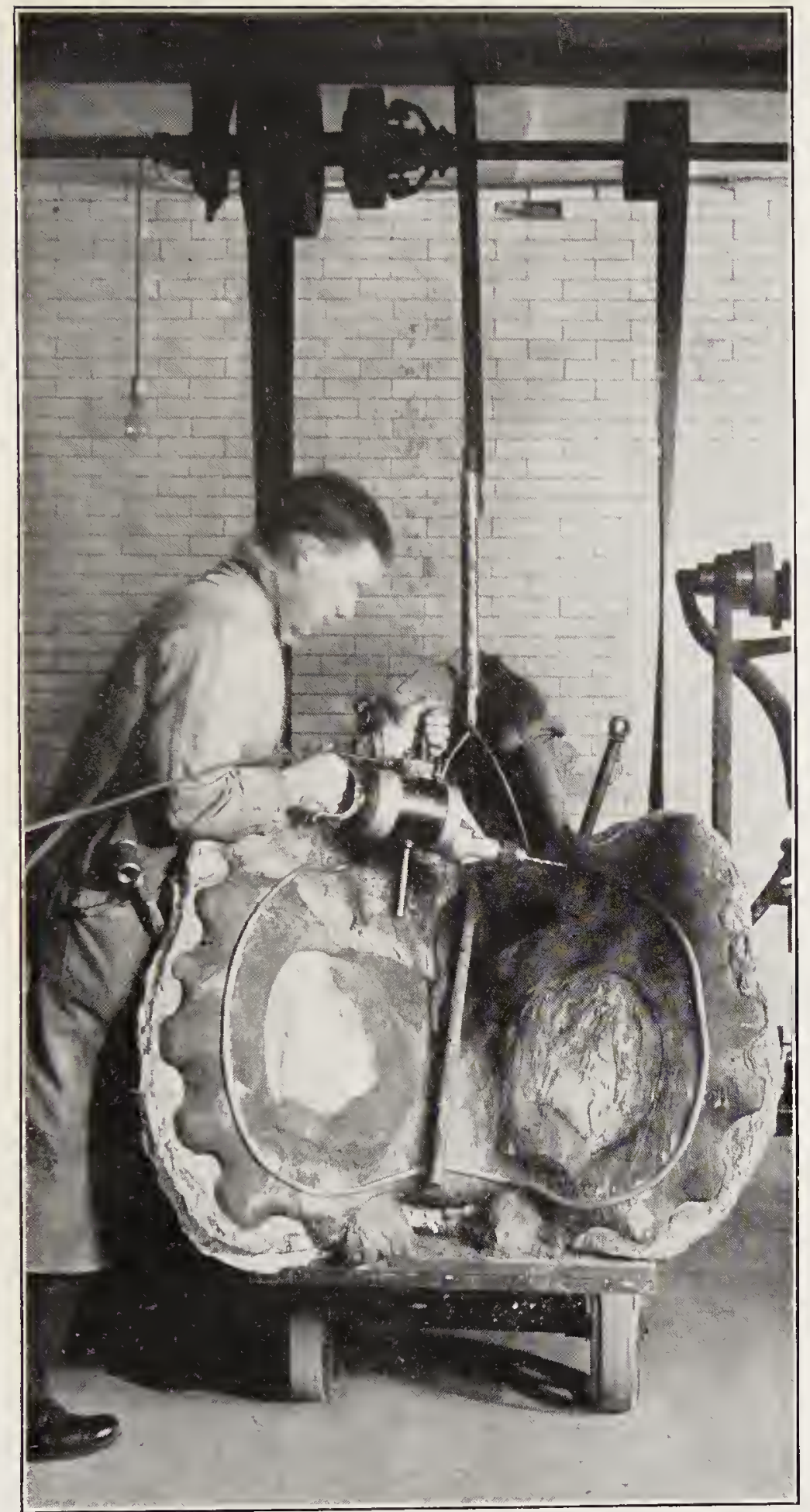

Fig. 36.-Putting irons on the Centrosaurus Crest.

Page 83. 


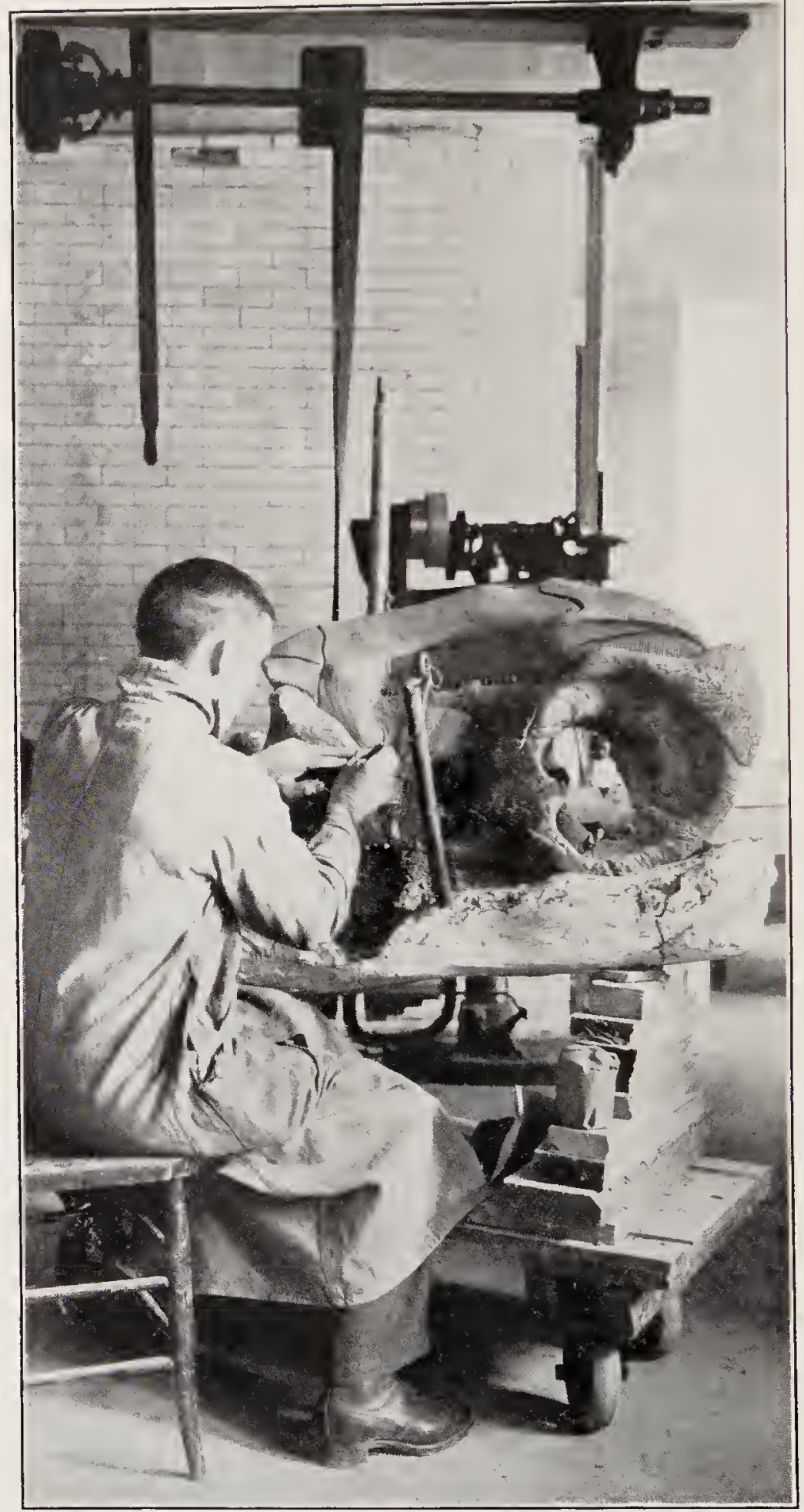

FIg. 37.-George at work on C. H. Sternberg's Centrosaurus. Page 83. 


\section{Another Strange Horned Dinosaur 121}

thirty-five feet of solid sandstone to remove. He needed Charlie's assistance very badly. But I was determined, if possible that he, and I too, each should find a specimen worth collecting. Our journey down to Dog Creek, Montana, had given George some three weeks the start of nis in hunting, and he had been very successful. As every lumter likes to tell of his companions lnck in the field, so also he likes to have trophies of his own. So we searched over miles and miles of badlands, week after week I was completely exhausted at night, after' a day's unsuccessful hunt. There is no work so trying, as that of clinging lour after hour to steep ascents, and searching every inch of exposed surface, in and out among the winding slopes. Often we would climb two hundred feet or more to the head of a coulee, to find after going a few rods, a land slide had taken down acres of shaken up strata. Then we wonld either climb to the summit, and go around, or go down to the bottom and climb up on the other side of the slide. In many places we were obliged to nse our picks, as our chief dependence, in walking around some almost perpendicular escarpment, or to cut niches in which to secure a treacherous foothold in the steep slopes. I know that when I got to camp at night, and had set down to our camp table, to eat the fine supper, Mr. Johnson had prepared for us, appetising indeed, as he made bread and cakes and many other dishes not usually expected in camp where pan- 


\section{Another Strange Horned Dinosaur}

cakes and baking powder biscuits are the rule generally; my feet would swell so badly I would often be obliged to crawl on my hands and knees to my tent and cot. There, stretched at full length, with lamp above me, I read until bed time, never thinking of getting on my feet until the next day. When I went through the same experience. Charlie, as I said was the lucky one, he found the most complete skull of this strange creature we have ever obtained. The Figure 26, shows it in its rocky sepulcher after it was uncovered ready for wrapping. In order to get to it we were obliged to leave our wagon on the prairie, and go down into a coulee some five hundred feet below; cross over, and on a road we made, haul our sled to it a hundred feet above the river. Although the skull is badly injured by pressure. it is so perfect that all the sutures between the bones can be detected, as in the case of the Chasmosaurus skull, George discorered.

I was able to completely restore my specimen from Charlie's. So we have now mounted in the Hall of Vertebrates, two skulls. The picture No. 27 shows some of the characters quite well. The nasal horn is curved forward, and there are two short horms over the eyes; while in my specimen, Figure 27, there are none.

I would like to take you to my shop again; where George is at work. He is putting on the steel half ovals, that are to hold ip the crest; he is using an electric drill as you notice, Figure 


\section{Another Strange Horned Dinosaur 123}

28, and boring holes through steel and skull so the bolts can be inserted to hold the crest securely to the crest. In the back ground is the inch tube that holds the ends of the half orals, and is the standard that will support the skull, on the pel'manent base. It all looks very simple, but it represents a great deal of skilled labor. The strip of half oral steel that supports'the crest, was heated hundreds of times and beaten to fit inequalities in the surface of the crest. It must fit exactly, so there is no spring in the steel, otherwise when the plaster jacket that covers the top of the skull is remored, the spring will break the bones. The jacket is made of separate sections fitted closely to the top of tha skull. It serves two purposes, that of giving a firm, uniform base behind the bones, so ther may be clean. ed, and also to enable us to turn the skull over by looping a rope orer it, fastening this to the triplex block that rides on a trolley moving on the eye-beams fastened to the ceiling. The skull (Fig. 28), is then gently lifted, turned over, and the upright set in the permanent base of polished mahogany. Then the jacket should lift off, as in the case in hand. After cleaning the upper surface, the skull is ready, as you see it, for permanent exhibition (Fig. 27), with the exception that the glass case so necessary to protect it from dust, and vandal fingers has not yet been put in place. It took all four of us, many months to complete this skull for exhibition. I worked 


\section{Another Strange Horned Dinosaur}

on it nearly all one winter cleaning off the bog. iron that covered it completely. If you will notice closely the rough skull, especially with a glass, you will see the bones were fractured in all directions. The first thing I had to do, was to fasten these fragments securely in their places. so I could remove the iron rust that clung firmly to them. After many experiments with shellac, I found a thin solution of ambroid was the most satisfactory. It would penetrate better than shellac, and when dry, was hard as the flinty rock itself. If any of the fragments broke loose under the tools I used, I must fill them again and again and wait twenty-four hours or more for the cement to set firmly. You will notice the lower jaw and crest seem rather smooth compared with the rest of the skull, and they are, because they are restored in plaster, from the complete skull Charlie found. The crest was chiefly prepared by Levi. This was done while it was still in the plaster jacket. It was first restored in moulding wax, copying exactly the perfect crest. I mean by that, the wax on the jacket was manipulated by my son until it was a facsimile of the original parts so as to be beyond criticism. Then a cast was made in plaster of the wax model, the wax taken away, and the place it occupied replaced with plaster colored as near the original color of the bone as possible, to prevent a discord, or lack of harmony in the completed skeleton. You see, then, we must be 


\section{Another Strange Horned Dinosaur 125}

mole than fossil hunters; and I must say though I have collected fossils nearly every year since 1867, and as my readers who have read my story know, have often suffered in the field, it all sinks into insignificance compared with the work of preparing the material for public exhibition. Take the skull I am describing from 9 in the morning, with an hour's intermission at noon, until 5 P. M. I must have perfect control of myself, I must not make a mistake, or I may ruin the entire skull. That not only represents a great deal of expense, but is largely the result of a lifetime spent in a business to which I was born; without that experience and that of my sons, through most of their lives, in all likelihood, we could nerer have discovered $\mathrm{or}^{\circ}$ collected it. Then we do not work for today alone. As long as the Victoria Memorial Museum stands, this and the other Red Deer Dinosaurs we collected, and prepared, will be admired. It is because men will forget the worker in their admiration for these strange relics of a day some three million years ago, that I am going so exhaustively into detail, the life of a fossil hunter in field and shop, so that the observing public, when they go through one of our great museums may feel they are on holy ground. The creatures of the misty past are before them; God's creatures, for if he cares for the raven, for the fall of a sparrow, he must hare cared for the creatures of his hand, that existed so many ages before man appeared - these 


\section{Another Strange Horned Dinosaur}

lords of creation, that domineer over God's green earth.

Look at the picture again, and you will notice two long spike-like projections over the openings in the crest. They are evidently not horn-cores, but bundles of ossified tendons, over which the muscles intertwined, that controlled the powerful lower jaw. The entire skull is over fire feet long. Two horn-cores bend inward in the center of the crest behind, and the rounded sides are scultpred into bony knobs that in life were doubtless covered with horn. This creature must have been as large as the spiked dinosaur nearly-at least nine feet long to the drop of the tail, although I did not discover any skin impression similar to that in Chasamosaurus, the environment was the same boggy swamps and mossy meadows, his skin scales were colored to harmonize with his surroundings. He would not be noticed when asleep in some rushy embrassure, and when feeding, he was ever alert, ready to flee from his enemy Gorgosaurus, or if need be face him and fight it out, as we saw the spiked dinosaur along the margins of the cretaceous lake. 


\section{CHAPTER $\mathrm{X}$}

IN THE MILK RIVER COUNTRY

Charles M. Sternberg went ahead of my expedition to Milk River Station in southern Alberta, exploring on horseback a great stretch of country along the Milk River divide, and east seventy miles, or more, where the great gorge of Milk River cuts a gash five hundred feet into the Belly Rivel Series. Levi and his assistant Gustar Lindblad, also went ahead, and secured our team and outfit from near Drumheller, Alberta, and made the long journey by wagon, so when I reached Milk River Station, I found both boys waiting for me. From Charlie's report I became convinced that we had come into barren ground. I also found that the so-called Belly River Series of Dawson, who likened it to "an island in sea of drift" was not on Canadian soil, but in the Black Foot Agency Reserve in Montana, where Mr. Gilmore, of the National Museum had discovered new trachodonts, and horned dinosaurs. As I had no authority to visit and collect in this rich field I was obliged to give it up. I was so near, and yet owing to red tape, so far, from a field I had come to explore; expecting to find it on as Mr. Dawson believed, on Canadian soil. I have since learned from Mr. Brown, the Associate 
Curator of Reptiles in the American Museum, and the man I consider the greatest collector of extinct reptiles, that these exposures belong to the Edmonton Series of which we have such splendid exposures on the Red Deer River, in Alberta. This fact has greatly lessened the disappointment. However, as misfortune never comes alone, a thorough exploration of the exposures of Milk River, Alberta, revealed the fact that they too, were quite barren of vertebrae fossils. On the afternoon of the eighth of June, 1915, with all my party together, we drove down to Verdegris coulee, twelve miles east of Milk River Station. It is a comparatively wide valley, rather barren of regetation. There is a large lake named in honor of the Deputy Minister of the Department of Mines, Mr. R. G. Mrconnell, a short distance above camp, on the coulee. There are rather extensire exposures, along the slopes that lead up from the ralley to the prairie a hundred feet above. The lower reaches are purple, yellowish, and reddish clays, and sand into which one sinks while walking. Abore is yellowish sandstone that stands out in bold escarpments in places, it is washed into steep slopes. In this coulee I found some fine leaf impressions -Platanus, Poplar, and a splendid palm, shaped like a date palm. The fine palmetto palms, I found above the Lance Beds in Wyoming, were fan-shaped. These, howerer, hare long, lanceshaped leaflets from a common central stem. I 


\section{In the Milk River Country}

described it to Dr. F. I. Knowlton, of the U. S. Geological Survey last winter, and he has never seen anything like it. It is evidently new to science. From a letter received lately I have learned our suppositions were correct. This is the first Paln of this kind seen by men of science from the Cretaceous Age.

At the mouth of Verdegris Coulee, Charlie photographed some remarkable fine rock forms carved out by nature. The photograph showing the urn-shaped mass, was formed by a sand blast operated by the winds, that whirled around the mass that had been separated from the main rock in the recession of cliffs. The top layer being harder than the rest, it was corroded more slowlr than the lower and softer layers, producing the wonderful urn. The sand and wind pol ishing and planing away the rock, as effectually as if had been a broom stick under the action of a lath. I think this one of the most beautiful designs of nature I have ever seen. The second picture Charlie thinks resembles an "Egyptian Sphinx."

On the 12th of June we reached our camp in the valley of Milk River. In the very center of the exposures, some three miles above where it crosses the International Line, and flows towards the Upper Missouri, in Montana. On the 15th mo notes record that I had gone over the entire series of rocks from top to bottom, finding only a fer isolated crumbling bones of dinosaurs, of 
the Belly River Age. The first two liundred feet (speaking approximately, as I had no instruments of precision), of the exposures are chiefly clay, with oyster shells scattered through them; also on top, quite a layer of oyster shells in a yellowish sandstone, filled with iron. Just above are two persistent layers of coal, or very black bituminous shales. One vein, I concluded, must have been between two and three feet thick. There are places where this vein lıas been worked by farmers, evidently, from the prairie above. As the coal is seventy ,miles from the railway at Medicine Hat, it is not likely anpone will be found to work it extensively. Abore the coal are heavy strata of yellowish or grey clays, with intervening beds of greyish and yellowish sands. On the summit of the bad lands are huge concretions, weighing many tons, each lying in yellow sand. In this sand, too, I found the best prospect for fossil bones I liave seen in the region. I found a perfect femur of a trachodont running under one of these heavy concretions. Owing to the fact that where there were no concretions, the sand disintegrates so easily, gxass and otlıer plants always take possession and cover the sand. So if there are any skeletons here on Milk River they are covered up.

Above the coal veins for about three hundred feet there are beds composed largely of mussels and univalves, showing that great piles of them were heaped in drifts along the ancient shore. 


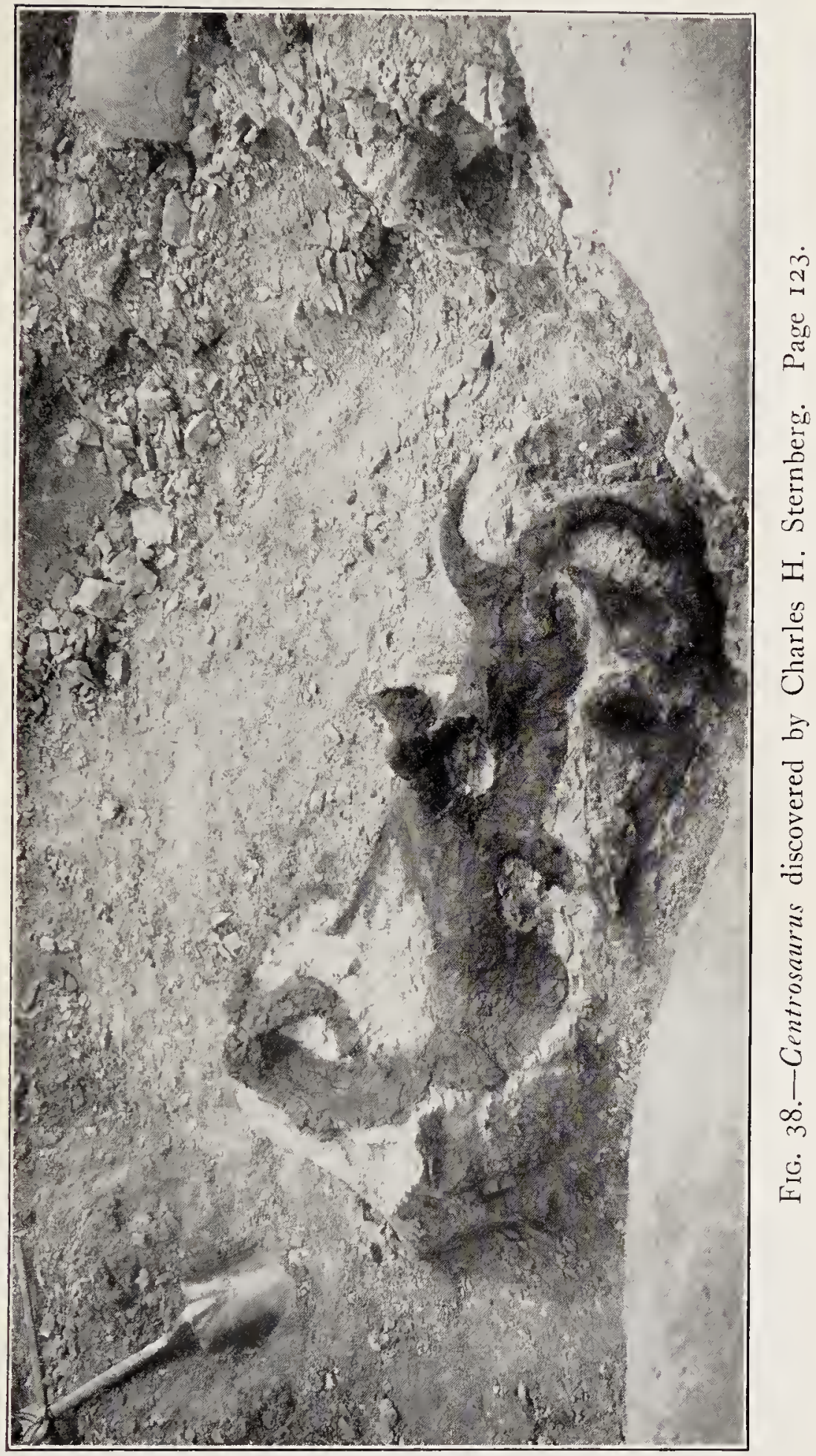




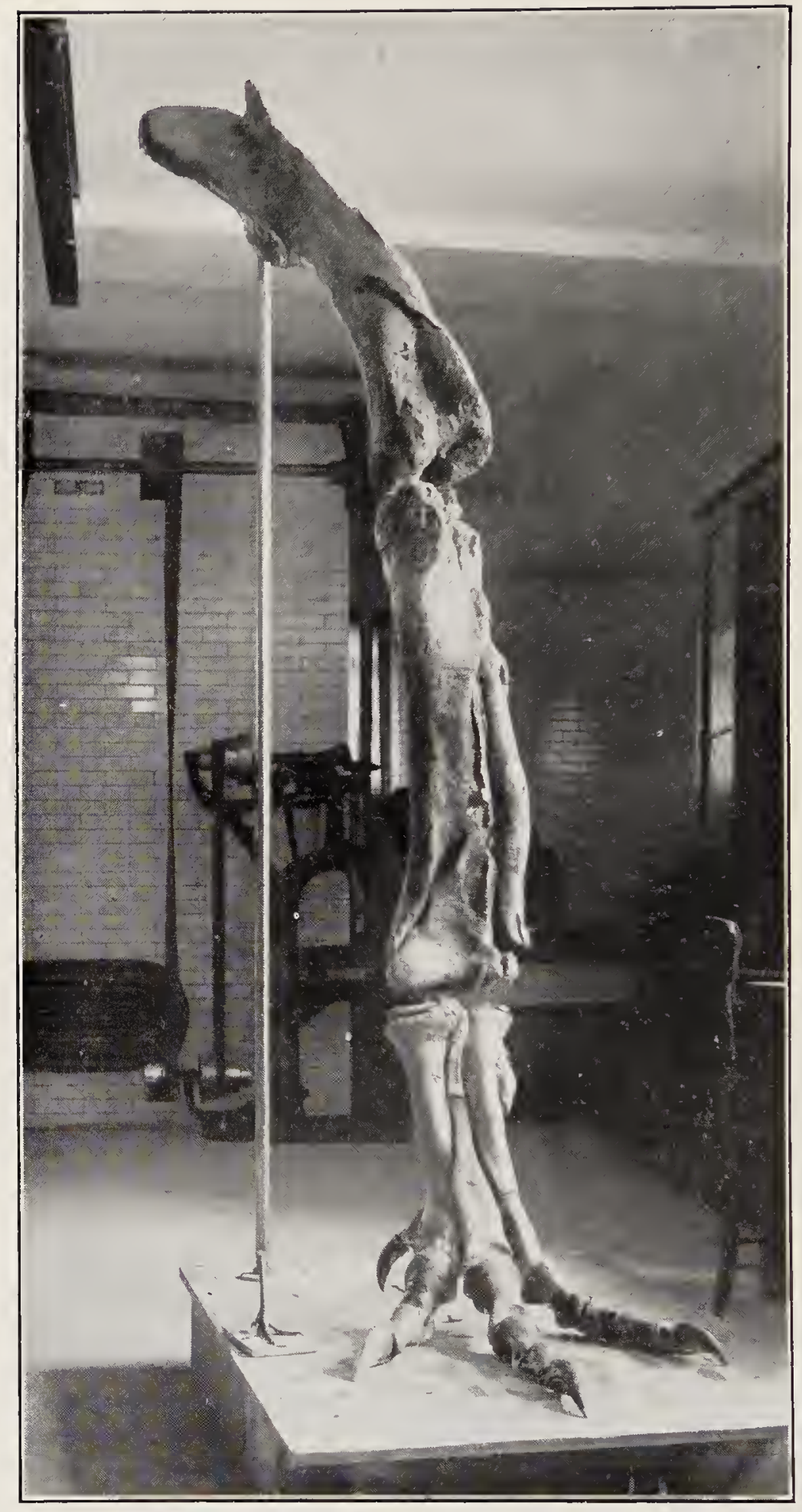

FIG. 39.-Limb of Gorgosaurus Mounted by Charles M. Sternberg, Page 58. 
We could have secured tons of these shells, that to all appearances might have died yesterday. Many had the original shell with its pearly lustrous layer attached to the inner cast of mud that filled the shells. Usually, however, when a shell was disturbed it fell off and left the cast in my hands. I learned many things about this great exposure. All the various rocks show they have been laid down undel watel. I can imagine a great flood plain along the cretaceous ocean at first, just below the surface of the water, that must have been brackish at first for so many oyster shells to accumulate. There were no great reed and rush covered plains where the lorned dinosaurs could feed; no bayous or lakes bordered with dense jungles of vegetation, where countless swimming duckbills enjoyed the luxurious feeding places, but a shallow waste of waters, where oysters secured a precarious foothold. Then the scene changed. The land was raised sufficiently so a rank vegetation of sponge moss and other forms covered all the rising land until a vast bed of vegetable matter had accumulated, when it went below the sea and was covered with ocean mud and eventually compressed into coal. Then again the land was lifted above high tide, fresh water for many years spread out in shallow sheets over the region in which there was sufficient moss and other vegetation to provide food for the univalves or gas- 
tropods, and a multitude of mussels plowed through the muddy sand.

We had so much rain that we were not only delayed, but feared we would never be able to pull our load of haggage out on the prairie. The road we used to get into the valley, marle by farmers, was impassible when wet. I became very much discouraged, as there is no harder work for a fossil hunter than to walk day after day over barren ground. Professor Cope once sent me in on a hypothetical fossil hunt. He had decided in his own mind in Philadelphia, that above the Permian beds of Texas there was a new horizon that would yield new extinct animals, he wanted to be the fortunate discoverer of the new fauna. I had, however, explored this region years before, for the Museum of Comparative Zoology at Cambridge, Massachusetts, and I knew it was barren. Owing, however, to his insistance, I yielded my judgment to his, to my cost, and spent a month of useless effort, heart breaking indeed. That was the last time lie ever attempted to give me instructions from Philadelphia when I was in the field.

On the 25th of June, after exploring the Milk river country, and finding it barren, we camped on our way back to the rich Red Deer River beds at a point fifteen miles south of Medicine Hat. We had just pitched out tent when a violent wind storm as bad as the winds of Kansas, struck us, accompanied with rain. We escaped serious 
trouble, but a little town west of Medicine Hat was badly wrecked, where the wind developed into a genuine cyclone that tore down houses and scattered chimneys and loose boards over the prairie. Thanking God for our escape we passed north next day. At Medicine Hat I went aliead by train and left the boys to follow with the wagon. From Brooks I went over to Steveville. On reaching the river, however, I found it was at full flood and covered with driftwood, logs and lewn timber. The ferryman, Mr. Shaw, came over for me in a row boat., and I had so much confidence in him as a river man that I trusted myself to his keeping. His skill with the oar brought me safely over the raging Red Deer River. He avoided all the logs and other drift-wood, and landed me in safely on the northern shore. Even then I found the river had backed water up the creek between the ferry and steveville, and I had to walk a long ways to get above the back water. After quite a journey I reached the hospitable hotel of Steve Hall. It was a full week before the boys reached me and we got once more into camp. They were delayed by the high water. 


\section{CHAPTER XI}

THERE WERE GIANTS IN THOSE DAYS

For days I had been exploring the brakes of the Red Deer river in Alberta, Canada, for the wonderful extinct dinosaurs of the Cretaceous Period. They had only been known since 1876 , when the late Professor E. D. Cope made his famous expedition to the Bad-Lands of the Upper Missouri, in the beds of the Judith River of Montana.

I was exploring the valley of the Red Deer River at Drumbeller. A great chasm in fact, cut by the river and its tributaries four hundred feet deep into the Edmonton Series of the Upper Cretaceous, out of the very heart of the prairie. Across from plain to plain the distance averages about two miles. Tributary creeks and coulees have carved trenches further back into the plain; while in the main valley, especially near the brink of the prairie, are long ridges, tablelands, buttes and knolls, pinacles and towers, whose bases often impinged on the ox-bows of the river itself; down whose rugged sides a stone rolling would bring up in a sudden halt, in the waters four hundred feet below. All this region, except of course the river channel and flood plain, was transformed by nature's sculptury into fantastic 


\section{Ancient Giants}

badland scenery, the rocks carved into the most intricate patterns, entirely devoid of vegetation, except, perhaps, along the northern slope of some rounded bluff, where sponge-moss had secured a precarious foothold; while running through it were trailing junipers, and spruces, with flowers of many a hue (to delight the eye) after searching the steep and barren slopes for hours. These slopes were corered with cherty fragments that rolled under the feet, threateing to hurl the artventurous Fossil Hunter in to the gorge below. I had found great quantities of the bones of the huge dinosaurs, or "terrible lizards." Among them the trachodonts or duck-billed dinosaurs, were the most common. Great swimming lizards they were, spanning thirty feet or more in length. My party had alleady two skeletons. One of them thirty-two feet long, we mounted afterwards in the Victoria Memorial Museum at Ottawa, Ontario. We found quarry after quarry where the bones had been piled up as flotsam by some ancient tide, that for ages had ceased to beat on this land. Today the nearest ocean is 700 miles away, and the strata have attained an altitude of twenty-five hundred feet above sealevel. The day had been hot and sultry; as I came upon a coal miners tunnel (there are unlimited beds of coal in these breaks), I found relief by going in some distance. The floor was deeply covered with fine dust, making a restful place; and it is little wonder I fell asleep; I never 
knew how long I slept, but when I awoke, I was overpowered with surprise, I could not teli whether I had awakened in eternity, or Time had turned back lis dial, and carried me back to the old Cretareous Ocean. At all events however, I found myself lying under a great red-wood tree. Stretching before me to the south as far as the eyes could reach, a mighty ocean liy as level as a thrashers floor to the distant horizon, while to the north an interminable forest on the low-lands, interspersed with countless lagoons and bayous, the oozy margins thickly planted with rush and horse-tail, and tall swamp-grass, while rast quantities of moss clogged the shore. East and west, the shore line was undulated by indentations, cut by river or bayou mouth, promontary cape and bay. The heat was excessive, and it was a relief to find shelter under one of these gigantic evergreens whose branches waved above the everglades; deep rooted in the soil, it had alreadr endured the blasts of a thousand years. Perhaps this mighty giant had witnessed many a tidalwave leap the borders of old ocean, and plunge with resistless fury orer the lowlands, uprooting trees of weaker fiber, sweeping a waste of peat and rood ont to sea, to be returned in mingled masses of regetation to $\operatorname{clog}$ the shore. Its last year's cones and leaflets lay on the ground around me, and put me in mind of the locality I had discovered but yesterday, where hundreds of cones and leaflets of the giant sequoia or redrood lay 
deeply buried in the flinty rocks of the badlands of the Red Deer river.

Like all noble scenes of natmre the mind cannot at once grasp them fulls, if it ever does.

The south wind had sprung up, the tide was rising, the waves were curling as they rolled on the beach: higher and higher they came capped with white foam. As far as the eyes could reach, long lines of breakers heaped tons of water on the shore, lashed by the frowning tempest. The sublimity of the scene was heightened by the colors in the west, that flecked the horizon with bars of gold and crimson; while the sun, a globe of fire, sank to rest in old ocean. I was lying beneath the tree breathing the salted air, partly in a trance. Is this real? I asked myself. Is the wind really sighing among the branches of the trees, that sheltered me? sounding like music of an aeolian harp, the tracery of interwoven leaflets acting as if they were stretched invisible wires? Is this a dream or reality? How often in other days while searching the semi-arid fossil beds of the west, in my day dreams have I put life in the old dry bones; how often some stately dinosaur has passed before my mental vision. The forests, the rivers, the lakes and oceans of other days, have appeared as if they actually existed. Is it incredible then, that I should be transported across three millon years, the distance between the living and the dead? "How fleet is a glance of the mind; compared to 
the speed of its flight, the lightning itself lags behind, and the swift winged arrows of light." Yes : modern science claims that three millon years have sped away since the end of the Age of Reptiles, since the Dinosaurs perished from the earth. Yet I was here. I could not doubt my own senses. I saw in the east the Queen of Night rise slowly from the bosom of old ocean, while to the west the last streak of departing day, glimmered once more and disappeared. Overhead the constellations of the temperate zone shone in undimmed splendor, as they did last night above the Albertian plains. Yes! there to the north was the Great Dipper"; its pointers as of yore, still led my eyes to the North Star. Venus too, shone as the "Star of the evening, beautiful star." Wha knows but some tiger of the ererglades, some huge Carniverous Dinosaur, may be prowling about for prey. A Fossil Hunter might prove a rare tidbit to him. It were better in my unprotected condition to seek a place of safety. I noticed that some of the bushes that lined the thick jungles around me had long powerful thorns, while running vines, had fibers as tough as hemp. I had my collection bag still with me, with its chisels, kuives and small hand-pick. So quickly cutting some long thorns and binding them to my shoes with the vines, I sought a small tree, the crown of which was hidden among the lower branches of the redwood. I climbed by forcing the thorns into the bark of the tree, around which 


\section{Ancient Giants}

my arms were clasped, and I ascended with the same ease that a linesman climbs a telegraph pole, driving the sharp steel spikes fastened to his boots into the wood. When I got among the lower branches of the huge tree one hundred feet above ground, I crawled down to its juncture with the trunk where I found an airy chamber, its floor covered with dried leares. Stretching myself at full length upon this fragrant bed, I offered up my evening prayers to my Father in heaven, knowing that I was being guided by His hand. Ah! had he not led me through the wildermess for forty years in His cemeteries of Creation, among the countless creatures of His hand. My mind took me back to the many forms, I had recovered, and saved from the destroying agencies of time and the randal hand of man. I remembered I had eighty-fire distinct species of extinct life in Munich Bavaria where the late distinguished Paleontologist Dr. von Zittel had once written me that I "had erected in Munich an immemorial monument to my name." I thought of the hundreds of species I had discovered that now helped form the great Cope Collection in the American Museum of Natural History, New York, that great storehouse of American fossil vertebraes. I thought too of my collection in the British Museum, and in the Museums of Berlin and Paris. Surely they prove that God has cared for me while I was "about my Father's business." I need not worry I thought, because 
forsooth He had carried me back to the close of the Cretaceous, that wonderful Age of Reptiles when land and air and sea were filled with, to us, strange forms of life; when great lizards shook the rarth with their majestic tread, sea. serpents and great bony fishes ruled the sea, while huge flying reptiles flapped their leathery wings over the deep. When I thought of all the creatures I had hunted for forty years, and dug their mouldering skeletons from an old ocean bed a thousand miles from the existing seas, from some great lake bottom, or the flood plain of an ancient river. I asked myself: Will He who brought me here leave me to suffer and to die? How often he had rescued me from sudden death. Shall I fear to lay me down to sleep alone with Him in this land nerer seen before by mortal eyes. Oh no! So peacefully I laid me down to rest humming Scott's famous lines:

"The heath this night shall be my bed,

A bracken curtain for my head.

My lullaby the warder's tread,

Far, far from lore and thee, Mary.

And so I fell asleep. No rude sounds disturbed; when the morning sun streamed in my eyes I awoke refreshed for the thrilling adventures of the day. It was spring, every living thing throbbed with life, the sap was surging through the trees arrayed in their brightest tints, the 


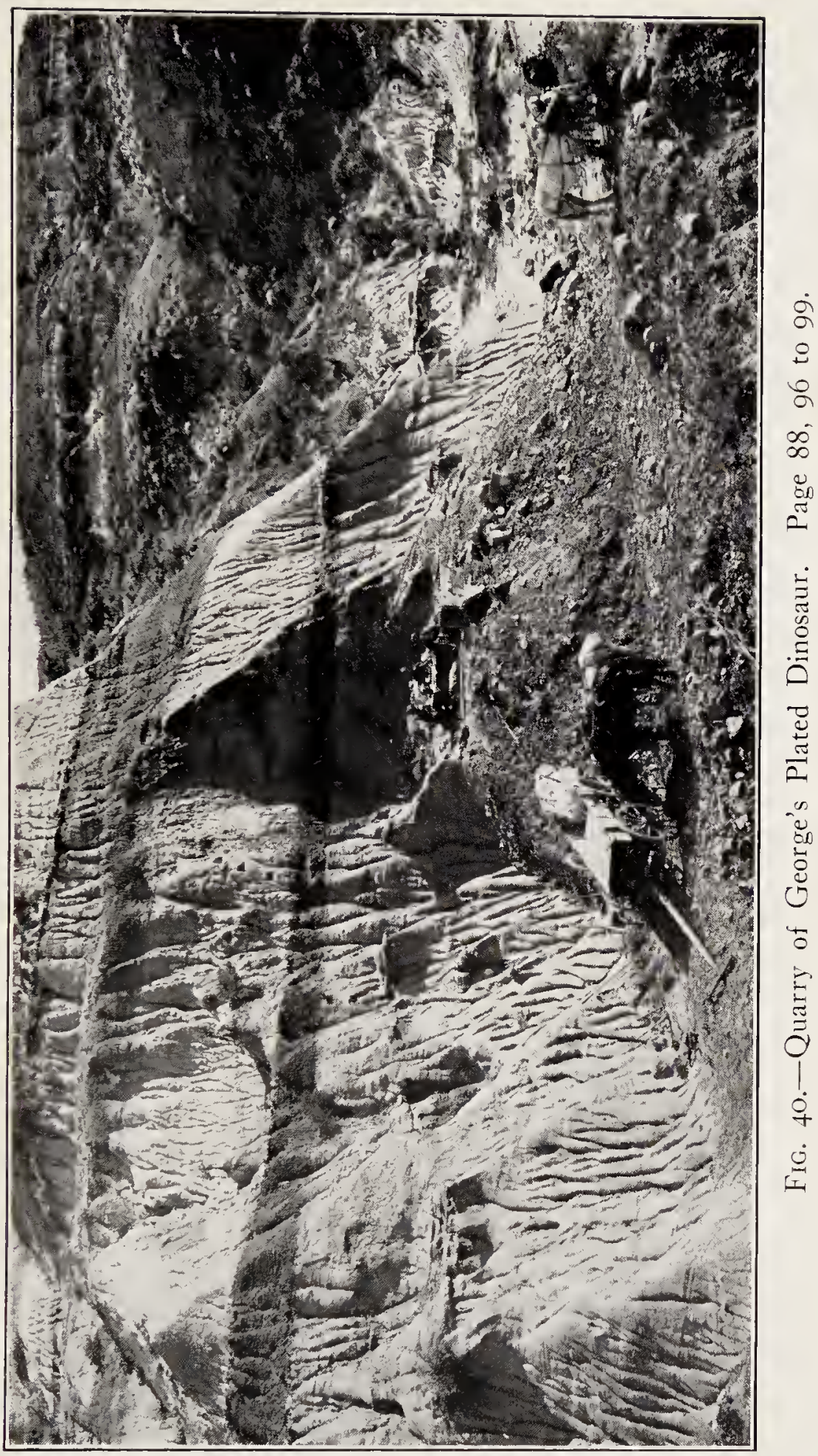




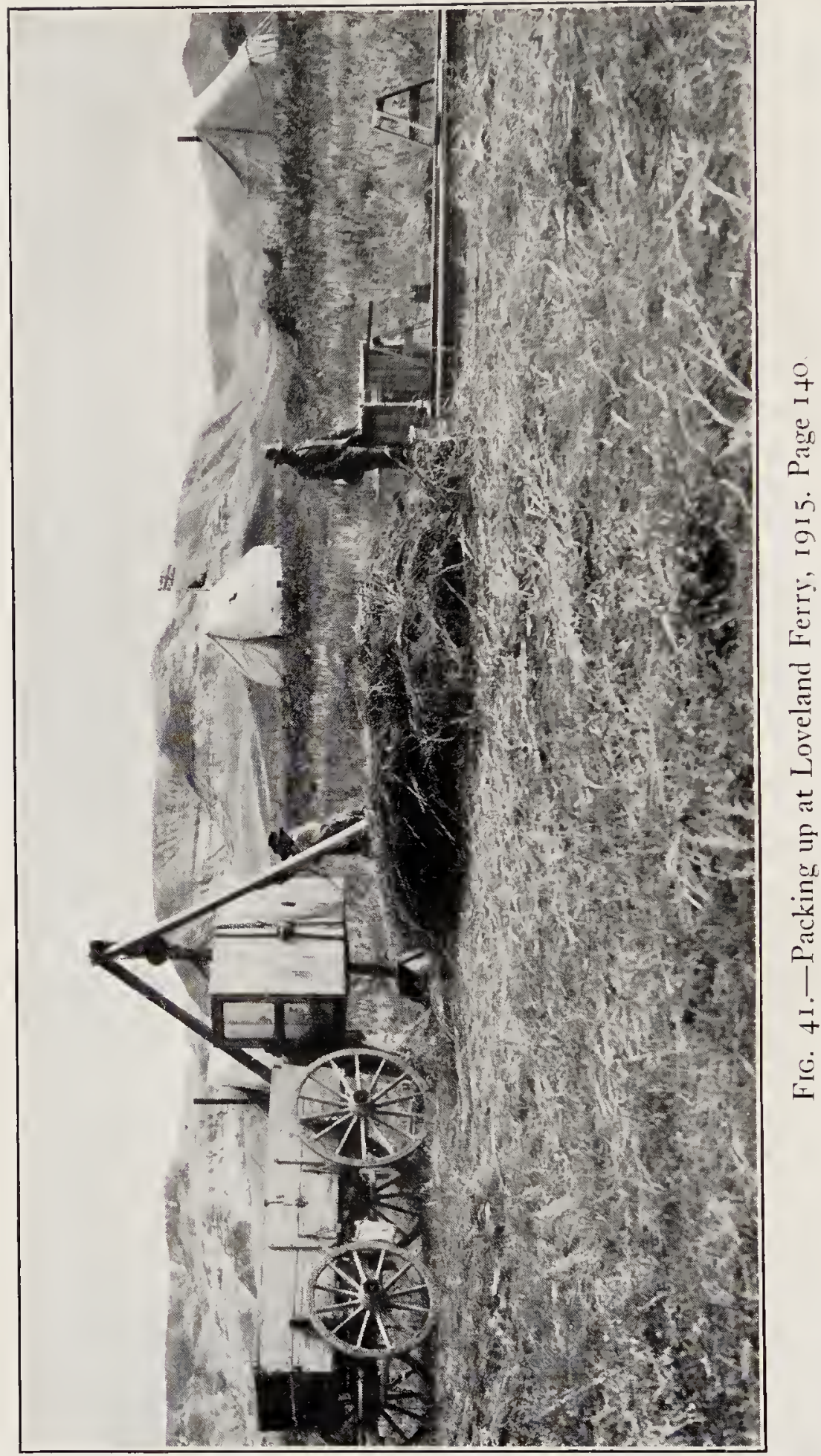


ground below was carpeted with flowers in endless variety and hue: there a clump of cvergreens, and here one of poplars, while in the distance figs, magnolias and a wealth of other trees added beauty and variety to the redwood forest.

Inshore the fertile zone between low and high tide swarmed with oysters, clans and mussels. They covered every arailable inch of space in the cares and crannies carved out of the ledge of sandstone along the beach by the ceaseless ebb and flow of the sea, or when the waves were dricen by the tempest's lash. As I had gone without supper the night before, I felt very hungry. Rapidly descending my tree I ran to the beach and gathered handsfull of the luscious shells, dripping with salt water. With steel digger used in collecting fossils I opened enough to appease a ravenous appetite.

The jungles behind seemed impenetrable, so I walked to the edge of the bayou, which emptied into the sea nearby. It was thickly planted with moss and rushes: but for the fact that there were logs ererywhere, lying at all angles in the molass I could not have gotten to the water. By teetering across the yielding moss, and resting on the half-submerged logs, I reached the sullen stream. I soon concluded that I must construct a boat, in order to explore the wonderful everglades. From the $\log I$ had a fine view of the bayou that wound its way through moss and swamp grass several feet high. The bayou ex- 
panded into lakes of considerable size, bordered everywhere with the redwood forest, and other trees on the rising land. With thick underbrush and high grass beneath, I noticed the water was full of gar-pike and turtles, the latter having beautifully sculptured shells, some of them a couple of feet in diameter. Among them I noticed the beautiful Trionyx, the shell marked with lovely designs. I remembered how, when on Professor Cope's Expedition to Montana in 1876, I was carried away with delight when I gathered from a sandstone bluff fragments of these shells belonging to the Judith River Beds of the Upper Missouri. But here were the living, breathing animals themselves; so oblivious of my presence that they crowded on the rery $\log$ on which I was standing. Man's cruelty to animals had not caused them to fear the human eye; an abundant food supply prevented viciousness. When I attempted to catch one, howerer, they all glided gracefully off into the water. Whole schools of gars and other fishes darted here and there in full view.

Turning back to the oyster bed, and searching along shore for a suitable piece of drift wood with which to make a boat, in the flotsam that lined the shore, I also found mingled with the driftwood and shells, moss and sea-weed, countless bones of dinosaurs, not brittle and filled with rocky material, as were those I found on Red Deer river yesterday, but bones with flesh 


\section{Ancient Giants}

and sinew still adhering to them, carried out as toll to the sea, from bayou or river. But the ocean soon tired of them and after playing with them until the time of high tide, returned them to the land with her own shells, seaweeds, and dead fishes, to fester in the sun.

These bones showed me they had lived but a few dars before, and were perhaps the remains of the feast of some titanic carnivore. I deter mined to go on a hunt for them. Here were limbs of duckbills ten feet in length, together with the strong ligaments that bound the bones together in life. Here, too, the mighty Tricera. tops has left a monstrous head, seven feet in length, to mingle with the drift.

The Carnivores were represented by powerful feet with three sreat claws, and a spur like a rooster. The feet along measured orer three feer long, the horny claws measured ten inches. Crocodilian bones and those of small reptiles and fishes lay around.

But as I was determined to find a $\log$ of the right size to hew into a boat, I wandered on, searching the drift pile with eager eyes. I could not be idle, and was determined to take advantage of the opportunity offered me, to study these wonderful creatures of a far-away day. I wondered whether they would in life prove what the students of their remains in the Twentieth Century supposed. I longed to know.

At last, after much effort, I found a redwood 
trunk over twenty feet long with a large enough diameter to make a comfortable dug-out. Luckily it was just above high tide, near the mouth of a bayou. With my hand pick I cut off the bark and fashioned bow and stern. Fortunately I had some matches in my rest pocket, I built a fire against the huge hollow trunk of a redwood, and was careful not to let it go out entirely.

Along the shore, washed up by the tide from the sandstone ledge, were numerous iron concretions, usually round and flattened on two sides. These proved invaluable. They would get redhot in my fire, and I used them for burning out the boat. A flake of flinty rock served as a shovel when fastened into a split stick, and two tied together at the ends made a serviceable pair of tougs. With these simple tools, my work proceeded famously. Parlles and scull, too, I made from strips of strong and pliable young poplars. With my fire kept burning, I had no trouble about food. I had always been a meat lover, and in camp a breakfast without bacon was a failure. So instead, I nuade turtle soup, or broiled fishes on the coals, or on sharp sticlis before the fire. I found nuts, too, and fruit, especially figs, the old ripe fruit hanging among the flowers and green figs. From tough bark I made sails and put sheets over all, to keep out the damp. With ropes of the aralia vine, I fastened my dug-out to a tree. One stormy night a very high tide floated her, and the next morn- 


\section{Ancient Giants}

ing I was ready for my expedition. So, all aboard, I committed myself to Mim who hoars "the ravens' clamorons cry," and drifted with the tide up the center of the bayou. With scull in hand, I guided my boat and with ny eyes drank in the beanty of the scene. It was a lovely morning cool and refreshing, the air laden with the spicy fragrance of evergreens that lined the elevated bench inshore. The delicious aroma of spring flowers delighted the senses, while acres of water lilies witl kidney shaped leaves and white and yellow flowers rested in graceful attitudes upon the water. Along the shore line were dense masses of moss; while serried ranks of rushes and long grass cast waving shadows athwart the sluggish stream. Behind on the solid earth the stately redwood, poplars, magnolia, figs and many other trees, cast their shadows across the bayou. These splendid forms

Of God's first temple reared,

Whose lofty trunks, like soldiers file As if their God they feared.

There they stand in solemn grandeur. Near the shore was a thick growth of underwood, while inland clear spaces were visible owing to the fact that the close crowned heads of the forest prevented the rays of the sun from passing through them to the ground below, and noth- 
ing but the liumble moss and other lowly vegetation could secure a foothold. I noticed sud. denly a disturbance up-stream, and suspecting that a dweller of this solitude was approaching a specially seductive patch of rushes and horse tails across the stream, I backwatered my boat into the fringe of regetation near the eastern shore, until it was completely lidden in an ambuscade of verdure. I anchored by means of a large concretion attached to a rope, of the running vine already mentioned. Carefully crawling to the front of the boat where I had made a small deck, I stretched at full length, and parting the rushes had an uninterrupted view of the barou. Soon, I saw the white foam ripple off the huge back and tail of a swimming reptile. A duck-bill if rou please, that was rapidly ap. proaching. The huge elongated head and short front webbed feet, the great body, and enormous swimming tail, the last as long as the entire body, made up a total length of about thirty-five feet. The tail was nearly three feet high, where it left the body, terminating in a small point over sixteen feet away. It was the main propellor that hurried him on his way to his pasture ground, in graceful and powerful undulations, aided by his paddle-like front limbs, feet and great hind limbs ten feet long. The water gurgled, and foamed, little patches of foam, were caught $u p$ by the passing breeze and carried to leeward. Soon he passed at full speed within 
ten feet of my shelter, and brought up a hundred feet away under the western shore. There he planted his hind feet firmly in the muddy bot. tom, ten feet below. The water continued its sullen flow, murmuring against the pillar-like limbs. The webbed front limbs, he used as arms to bring the rich foliage within reach of his duckbell to be nipped off, and passed between the scissor-like teeth that sheared the food into shreds, to pass into a carernous stomach below, and so appease a ravenous appetite.

I had a fine view of the beautiful creature. Back of the head a frill sereral inches high reached to the shoulder's. The whole body was covered with the most beautiful patterns of scales, or rounded tubercles, arranged in mosaic work of rery pretty rosettes, of scales perhaps an eighth of an inch in diameter with small tub. ercles between. The morning sun reflected in the water every scale and contour of the body, limbs and out stretched tail. And so this creature of other days was before me in flesh and blood and power. Over some parts of the body there were areas of large parement scales. They were entirely distinct, and did not overlap.

And his body broad expended With thin skin is covered o'er, Scaled in beauteous patterns blended With the foliage near the shore. 
The bright rosettas were nore highly colored than the smaller dots. As the thin skin hung loosely on the frame below, it moved in graceful curves loumded muscles, massive lind limb, and sweat tail. The hind limbs terminated in there large hoofs on each foot; that sprearl well over half a sifuare yard of the muddy bottom. The tail was adorned with large colored scales. He is now in his natural habitat, the Evelolades alongr. the old Cretaceous Ocean. The land was begin. ning slowly to rise from the domain of Neptune. who harl held sway for ages, but eren now, it was but slightly above sea-lerel, while meandering bayou, river or lake were interspersed between the low lands. There were great accumulations of peat, and other rank regetation corering weat areas of swamp-land, to the depth of thirty feet or more. Often no doubt, a great tidal wave will flood the rising land, covering the regetation with ocean mud, which in due time, in the ages to come, will form under pressure the coal fields of Alberta Province. We have alrearly noted her wealth of coal.

Our trachodon has fimished breakfast, and though at the time of writing these lines no one had suggested a name for him, the great question with me was how continue the study of this beantiful lizard, learn more of his life history and of the other creatures of his day. I concluder the rich everolades would abound in many of his kind, and a lich fauna too, includ- 
ing many other forms. As he continued to feerl I continued to think. I was not surprised to see him alone, becanse reptiles as a rule care litthe for their fellows. They do not mass together. in herds like mammals. Each one seems to live for limself, the stronger ones winning in the battle of life. They seem to latre none of the almost human sensibilities of mammals, show little love if any for the offsprings. As soon as the young are large enough for food, in the case of flesh-eaters, their hungry parents may gobble them $\mathrm{up}$, and ther are no safer from them, than any others of the hungry tribe. The only way to escape is to keep ont of the way. Of course our trachidont is, as we liave already seen, herbivorous in liabit; and is not likely to do battle, except in self defense, from jealously, or over the food supply. Neither would he lead others to the feast, each one must look out for himself.

I was not surprised that this fellow was a swimmer. In $1908 \mathrm{my}$ oldest son George, found a skeleton of a trachodon in the famous Beds of Converse County, Wyoming, complete except that the tail and hind feet were missing. He lay on an old drift on his back, wrapped in his skin, as in a mantle, or rather the impression of his skin, for the original substance had long ago disappeared. His head lay twisted under lis left shoulder. The skin in the abdominal region had collapsed, and lay across the inside of the vertebral column, all going to prove he had died in the 
water, that he was filled by the expanding gases after death, that his body was lifted to the surface and floated with the current, thus forcing the head back under the shoulders. When the gas escaped, the abdominal walls fell in; the water rushed in to fill the cavity, the body became heavier than water, and sank to the bottom. There the fine sand drifted orer it, and forced the yielding skin deeper into the body cavity. The decay of the contents of the risera and the flesh occurring more rapidly than the skin, the latter was forced closer and closer to the bones until the specimen, as now mounted in the American Museum New York, shows a resemblance to a mummy. So Dr. Osborn in describing it suggested the name "Dinosaur Mummy." Before this discovery, it was supposed that the reptile was a land animal, that he used his powerful hind limbs in connection with the tail, to form a tripod on which his powerful weight rested, while he fed off the tender foliage of tree. It was also believed that he was plated with dermal, or skin scutes, to protect him from his carniverous enemies. Howerer as the "mummy" proves, and as the living creature proved, his skin was thin, with no dermal plates. His front feet were webbed, and his habitat the bayous and swamps along the sea-plain. I was glad, as my saurian was through breakfast to see him lift his body, head and front limbs up, and look towards shore, and beyond a few rods away, to a sheet of water 


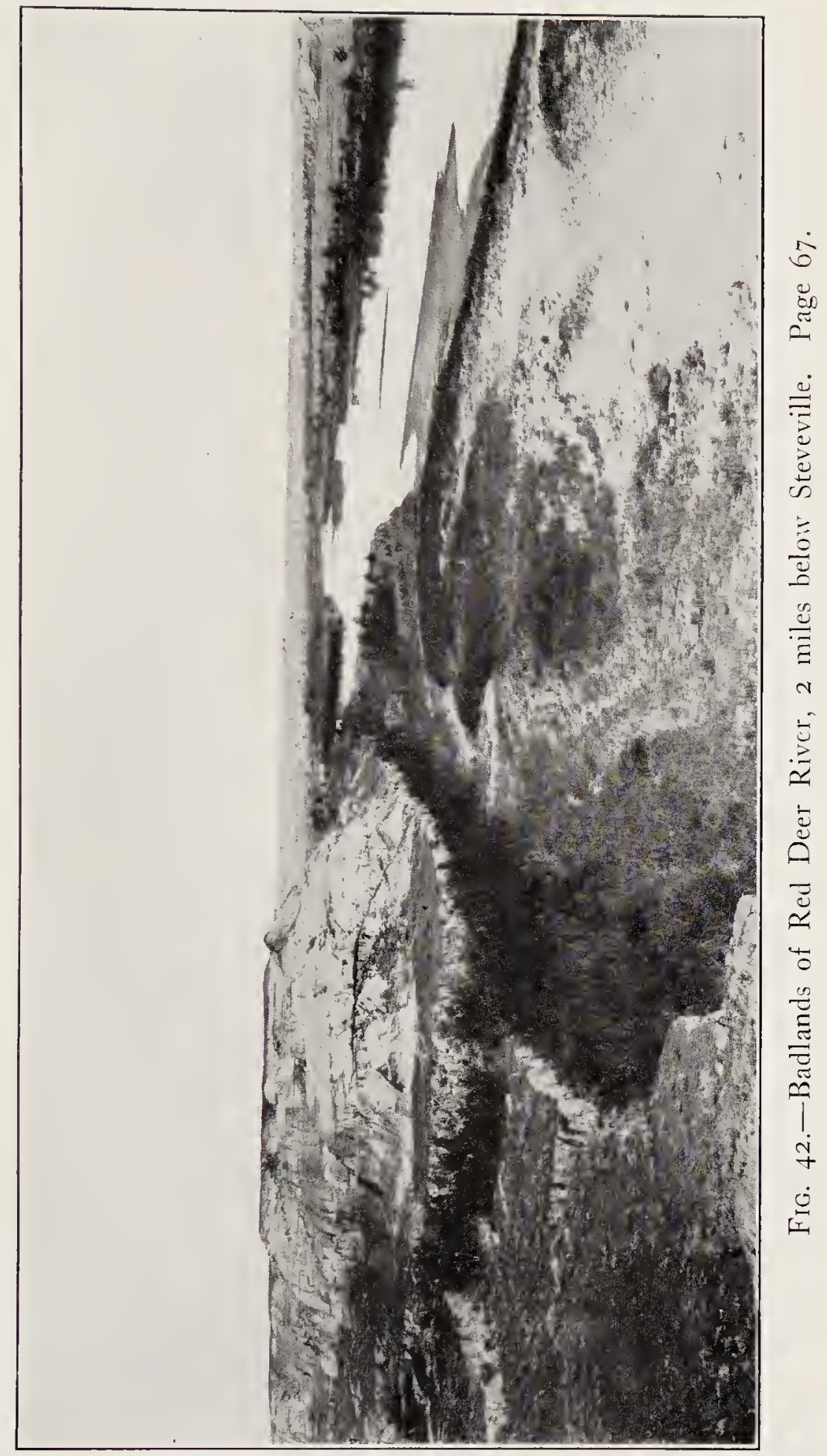




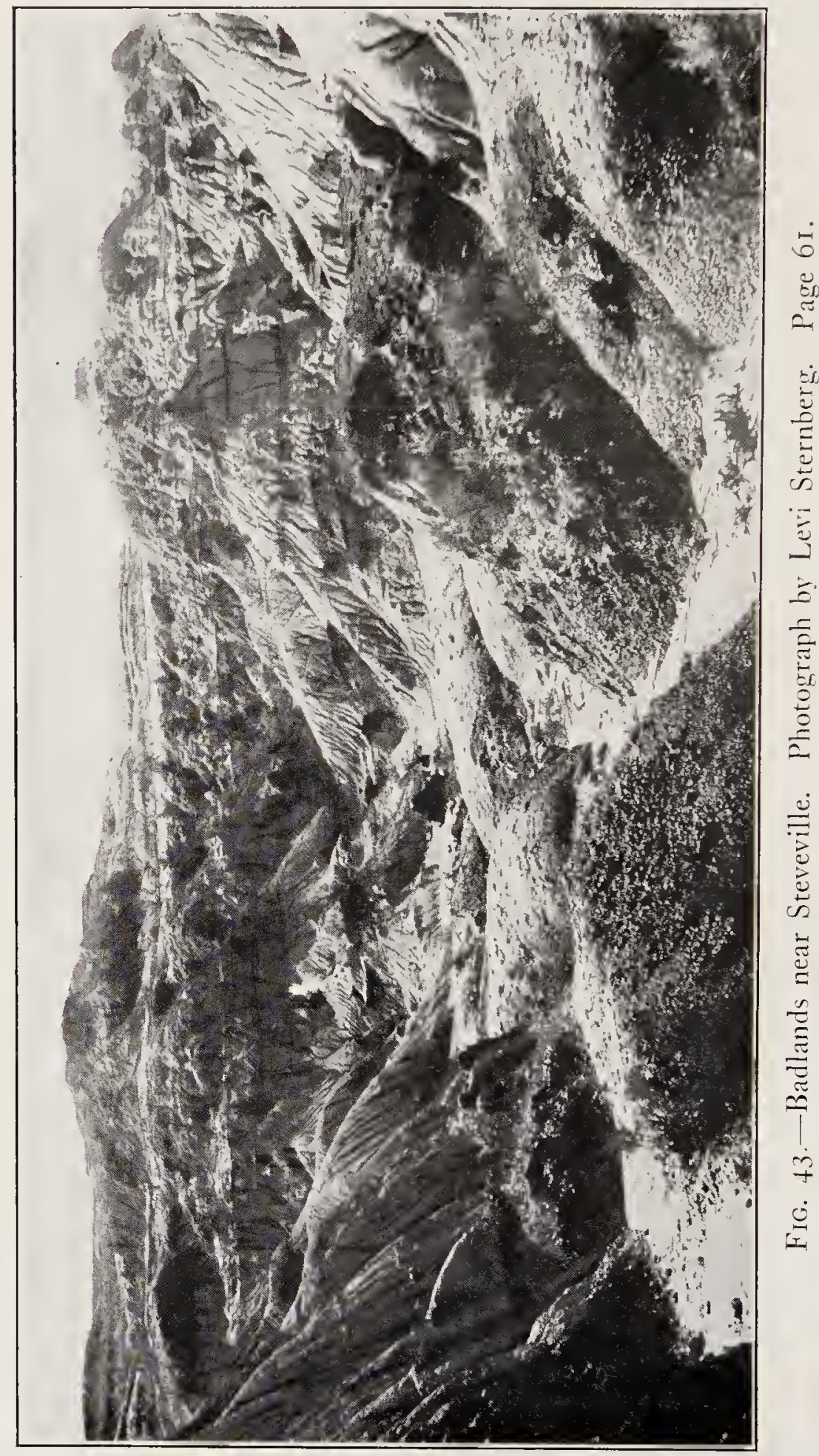


that appealed to him. So wading through the morass and putting his small front feet down on the muddy slope left by the retreating tide, the narrow strip between its ebb and flow, he drew himself out of the water, and lifting his body but a few feet above the mud, he dragged his huge tail through it, leaving a well marked trail behind. His pose to me was rery interesting, as I had come to the conclusion from my study of the "mummy," that this was his natural gait, though most American Paleontologists believe, that their usual pose was standing elect on the hind limbs, the front legs used chiefly for balancing. As he reached the fringe of bushes he pushed his duckbill through them, nosing around as if to scent some enemy. Then as the coast seemed clear, he hurries across the narrow strip, beneath the silent evergreens.

The cooling touch of morning breeze,

Waft incense from a censor, hidden, The gentle sighing of the trees

Add music to the scene unbidden.

As he hies him away "to fresh scenes and pastures green."

But hark a noise that thrills me, what can it mean?

I hear the crush of mighty frame.

The Tiger of the Everglades:

As onward through the brush he came, And through the swanp and moss he wades, 
He leaves a wreat trail in lis wake

As rusling forward toward his prey:

His mighty limbs with rase cam break:

And open wide a passage way.

His limbs are almed with claws so great,

His jalls ale filled with horrid teeth:

Alas! I fear our salurian's fate, He's simply dallying with death.

Our herbirole is armed for flight:

Witl paddles strong anr swimming tail,

He is not bnilt indeed for fight,

To 'scape by flood he should not fail.

For, though the reptiles weigh the same,

And each span forty feet in lengtl.

I fear the swimmer'll lose the same,

The carnirore excells in strengtl.

Let him escape beyond his foe,

Who dare not venture in the flood.

Toward the deep waters he should go,

Nor drench lis pasture witlı his blood.

Too bad! rush as he may, he cannot escape thi: filerce Tiger of the Everglades. So occupied are the great dinosaurs, they do not heed my approach. Lifting anchor I pulled across the stream into the channel made by the trachodon on his way towards slore. The noble lizard seeing that he could not escape his foe, bravely faces him. As if to hurry the end, he exposes the most vulnerable part of his body, by rising on his hind limbs. The enemy hurls himself at full length. 
upon his defenseless rictim; with nat claws of hardened horn, full ten inches long, lre rips his body down and red blood floods the mossy way. As he falls to earth and death, this tylant, of those eally days, tears open his body, and feeds on the quirering flesh and rumming blood in the very shelter of the redwool forest. The anful terror of the scene kept me well ont of reach in the water. I was orercome with the shock, coming so swiftly in the peacefnl woods. The sun was not darkened, the perfume of flowers filled the air, the gentle breeze sighed in the branches orerhead, showing that nature knows no pity, nu merey. That death is inevitable, and still nature's beauty, her changing seasons go on for time. Eren though the victim was a cold blooded reptile I had become deeply interested in it. I remembered however, that the carnirore must prey on the herbirore; that the latter increase so rapidly, the death of one of their number would leave scarcely a ripple on the reptilian life of the everglades. I had time of course to study the conqueror carefully, I saw he did not differ greatly from the one Professor Osborn described as Tyrannosanrus rex, the king of the tyrants: from a partial skeleton and magnificent head, discorered by Barnum Brown in the Hell Creek Beds of northern Montana. His huge head is four feet long, three feet wide and two feet high. The jaws armed with teeth six inches long, with serrated edges on the double cutting surfaces. A 
great sinewy body, very short front limbs, powerful hind ones, and long tail, with sled-like. chevion bones, and extending processes interlocking the caudal vertebrae, not allowing them to move freely on themselves, as in the snakes and lizards of today. The tail was stiffened and was dragged along on the ground. The body was 40 feet long and the head reached nineteen feet above the ground. As I saw, a blow from his terrible claw-armed hind limb, tore open the trachodon, nearly his equal in bulk. After gormandising to his heart's content, he drifted off into the forest, and I saw him no more. I then paddled in short and tying my boat to a sapling, went up to the carcass and secured great strips of the tough skin so beautifully adorned with shining and beautifully colored scales, polygonal

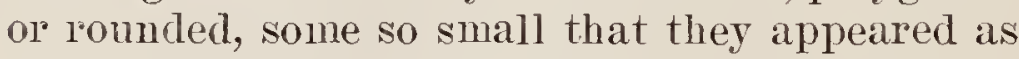
mere dots, as alleady observed. I was delighted to see near by a pool of alkali water, in this I doused the skin and it then only took a shori time to break up the glue. I found a poplar log: about eight inches in diameter and after sharpening one end, I drove it into the ground over a dead log that was lying on the ground. After peeling off the bark from the ends I had a handy device, so stretching the skin over it, scaly side down, and using the edge of a chisel for a scraper, I rapidly prepared the skin for use, cleaning off the fiesh and brokell down glue. By the time it was dry I lad tanned it, and it was as pliable 


\section{Ancient Giants}

as newly tanned leather. I continued my labor until I had prepared a great roll. Not of buckskin, but trachodon skin. I saw in prospect sails, ropes paulins for my boat and myself, as a protection against the rains and for many other things. Where the skin had been torn from the dorsal spines, I saw bundles of ossified tendons, like those of a turkey's leg. They lay across each other diagnonally to the spines, while other rows were parallel. What were they for? I supposed to stiffen, and strengthen the dorsal column. Perhaps too, if our trachodon had not been so foolish as to face his enemy, and had continued the retreat, and the tiger had leaped on his back, his claws finding no foothold on account of these same bony tendons, he might have lost his footing. They extended some distance into the tail, making the forward part like an oar. The undulations we saw, were performed by the posterior part of the tail while in the act of swmming. 


\section{CHAPTER XII}

WHAT THE CRETACEOUS SEAS BROUGHT FORTH

One has some strange day dreams often, at least I have. My only daughter died some years ago; though in imagination she is often with me, I thought once I had gone to sleep. When I woke next morning I realized that time had turned backward. I found myself beside the boundless sea, and it was not the sea I had looked on but yesterday, I was sitting under a limestone escarpment, with a beach before me of fine sand. The waves rolling outside of a bar that had bcen deposited by a river, whose mouth I could see on the eastern side of the steep bluff under which I sat. "Thank God," I cried, "You hare taken me back to the old Cretaceous Ocean." I had explored her elevated and denuded bed for twenty seasons in the Sliort Grass country of Western Kansas; collecting her rich fauna of reptiles and fishes. To know that I was to be permitted to actually see the animals themselves, in their natural environments. To explore her shore-lines. Her sheltered bays. To see her fleets of plesiosaurs come sailing in after an ocean cruise; her great mosasaurs, and bony fishes. How glorious, but where is Maud. The thought came to me like a flash. Life had seemed so much more enjoy- 


\section{The Cretaceous Seas}

able with her beside me. With her appreciative ear, to listen for what my mind conceived, and my lips uttered, she never contradicted me when I uttered an opinion. No! she realized that 1 , with my rast store of experience might well be her tealcher, and she enjoyed the story of my life so much that her eager face, and flashing eyes, were a stimnlus to my mind, atwakening old experiences and memories long forgotten. Although she had been with me for a short time, she had become necessary to me. I knew how much I would miss her in the adventures that lay before me. While these thonghts were passing, I was delighted to hear her gentle voice call out "Papa, here I am." And looking up I saw her leaning out of the mouth of a cave a short distance above me. I cried out with pleasure and rushing to the beach picked up the dry trunk of a small pine, with stumps of branches on either side. I carried it to the bluff and leaning against it, made a courenient ladder for Maud to descend on which she rapidly did, and stood beside me. Of course our chief talk was about this miraculous erent in our lives and we wondered what was in store for us. Te thrilled with delight when we realized how lovely the country was. The climate temperature. We smelled the delicious odor of magnolia blooms, for a beautiful forest skirted the hills and plains before us to the east, and north and south, while to the west, as far as the eye could reach a great ocean, whose western 
shore line must liave been thousands of miles toward the setting sun. 'Taking her arm we walk. ed down to the beach. In the zone between high and low tide, unlimited oysters, no larger than silver half dollars lay strewn around. While plowing through the sand, were Inoceramus shells that measured four feet high, and five feet long, leaving a great trail behind. The shore line was strewn with many of these huge shells. We mentioned the many uses they could be put to, for our convenience. Thin and transparent they would do for windows in the house, I planned to build. They would take the place of shingles, and even doors. We enjoyed a feast of law oysters with the sea water for seasoning. We then went to work hauling up from the piles of driftwood, trunks of small trees near the care. Which Maud told me would make her a nice room as it was high and dry with a floor of white sand. By building four walls with the logs, leaving spaces for windows and doors, we succeeded after many days of labor in having a room twelve by fourteen feet. Then we put on a roof, of the large shells, hung our doors and windows, filled the spaces between the logs with clay, and moss, built a fire place and chimney. The effect of the light passing through the shells was very beautiful indeed. Our original ladder led to Maud's Care, through a trap door. I gathered the fragrant boughs of pine trees for the beds. We cared little for furniture, pictures and ornaments. How insignifi- 


\section{The Cretaceous Seas}

cant man's costliest works compared to the works of the great Creator, His air, and water, His glorious sea forest and plain, the starry firmament on high, given us so freely. How rich we were, thongh possessing only the clothes on onr backs, and the few tools I had in my collecting bag. A few matches and some strings of sinew I had cut in another age, I also found a file in the lowest corner of my collecting bag, and from fragments of bone made some fishhooks, we had built a chimney and in the open fireplace Maud heated water in a deep sea shell while I caught a string of nice fishes, which she broiled for supper or fried for breakfast. I also found the tracks of a turtle, whose bones asd skull I discovered in the chalk of Kansas. Professor Cope named it Torycheles latiremus. Suspecting that she had hidden some eggs in the dry sand, I dug around in it with my hands and found a hat full of her soft shelled eggs. With the fish we had many most delightful repasts, and we talked of the time when we hoped to ex. plore this new region, the Early Cretaceous. Study its rich fauna and flora. After building our cabin, as we were very tired after a strenuous day, Mand kissed me good night and retired to her room in the cave, while I lay down in the corner of the house. At the first streak of day a fire was builded, and breakfast started. I had made a pail of a deep shell shaped like a woman's hood, and called later by Conrad Haploscapha 
groudes, the first great hood. I had bored a hole through either edge, and with an aralia vine for a handle, I carried it to a nearby hill; where a lovely spring of pure water gushed out, and returned with it brimful of the life saving liquid. We used thin shells, we had found on the beach, for plates and made our knives and forks and spoons of wood. At hreakfast Haud asked me if I knew where we were. "Yes, dear," I replied, "we are in Western Kansas. These limestone bluffs are composed of jointed limestone. Some day a gorge will be cut through them by the Smoky Hill River ninety feet deep, and a mile long, and it will be in Trego County just below the mouth of Hack berry Creek. Get your hat and we will see!" "I am ready, papa," she cried, so with collecting bag orer my shoulder, and pick in hand, we walked rapidly along the hard sandy shoreline. We soon rounded the point. and as I suspected the shore swung off into a vast amphitheatre-like core. We could just see the distant headland, far to the north. While the land and sea curved in toward the east and back to the north, forming a great land-locked bas.

"O see papa!" Maud cried, "what is that lying on the water just off shore? It looks like a luge log half-submerged." "No dear. I believe it is a Tylosaur or great ram-nosed lizard, the monarch of this ocean. See! he raises a conicai head above the water, that terminates in a long bony 


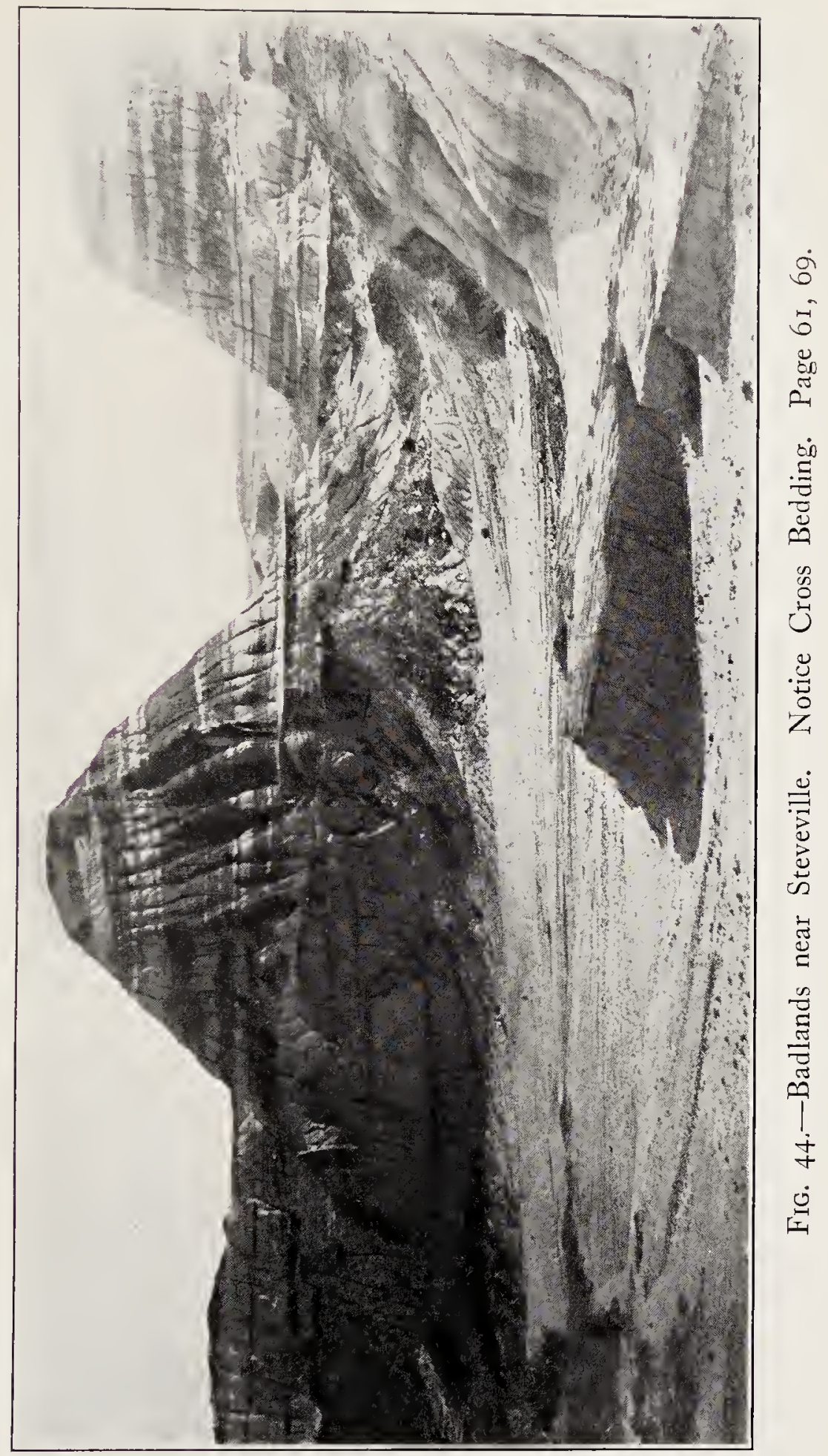




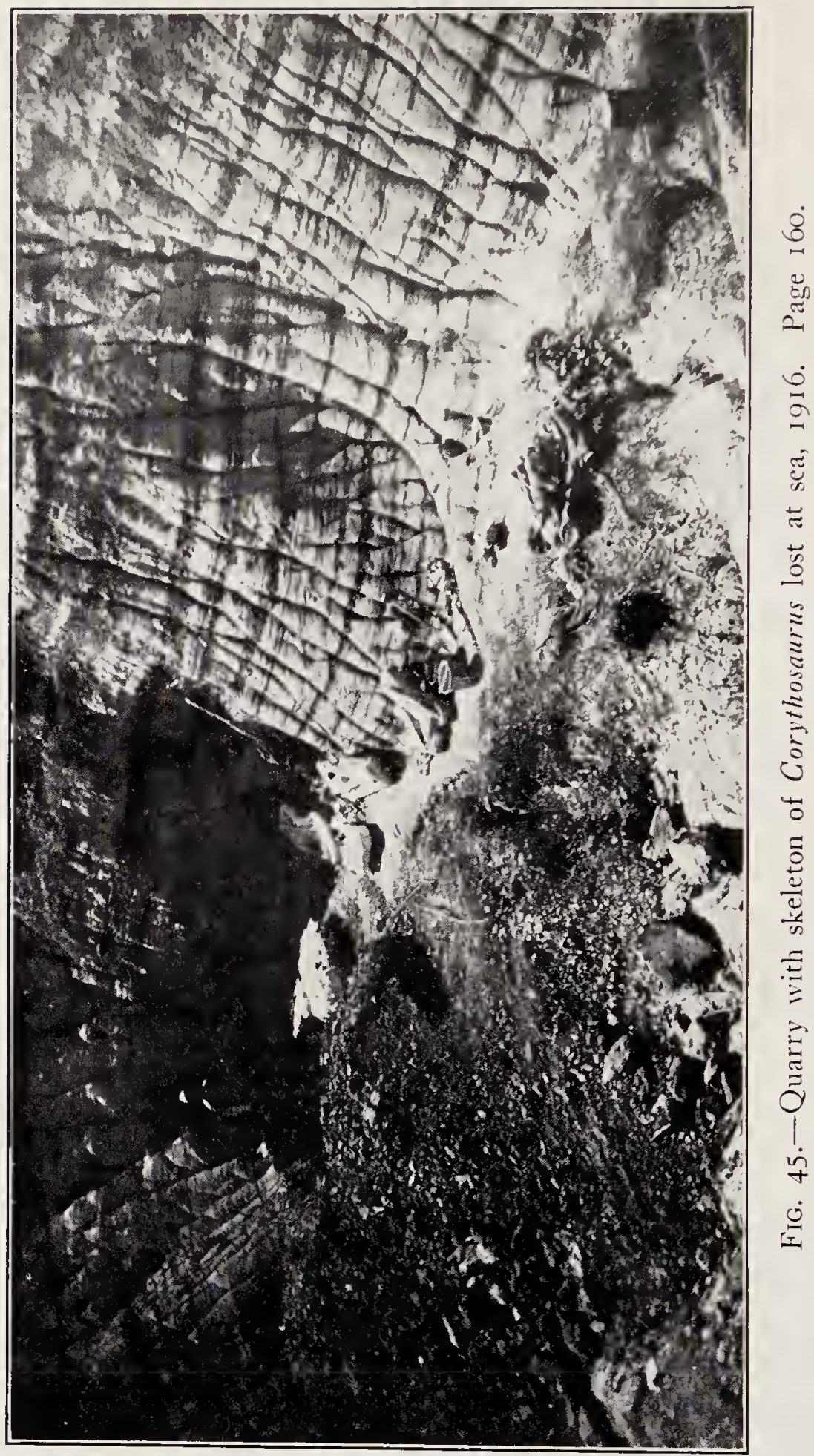


ram. His head is five feet long. See his four powerful paddles begin to move! his eel-like tail is longer than head and trunk combined. Watch its graceful and rapid undulations." "My," cried Maud, "it is larger than the storied sea serpents of sailors and seaside resorts. It must he fifty feet long." "Fully that," I answered. "I wonder what has started him off in such a hurry? "What does that streak of foam mean ronder?" asked my companion. It is another saurian coming to battle, dear," I answered. The scene was indeed exciting. We clapped our hands and shouted encouragement to our saurian as he lashed the water, and beat it into a foam, that floated belind in a long curling wake. Or patches were caught up by the passing breeze and wafted away as lightly as the bubbles children love to blow. We had ascender the point as we rounded it, and so are high enough to watch the battle royal. As they come together like colliding express trains, our reptile plunges his bony ram into the quivering flesh of his opponent, piercing heart and lungs. Withdrawing liis ram, he lingers near while the dying mosasaur redens the salty brine with his lifeblood. A few convulsive struggles, and he lies a helpless mass on the surface, while his victor hies away to other conquests. "I never knew these Tylosaurs grew to such huge dimensions," said Maud, "You know the one in the American Museum is only about thirty feet long, and that 
was considered large for the species." "Yes, I know," I replied. But I also know of one huge skeleton belonging to the University of Kansas at Lawrence, that measures fifty feet in length. His enormous head is five feet long, the same size evidently as this one. Who knows but that $5,000,000$ years from now his skeleton may be exumed from the chalk of Kansas and exhibited at the Museum of the University!" "I remem. ber the mosasaurs, papa, you described in 'The Life of a Fossil Hunter.' After the Tylosaurus came the flat paddles Platecarpus, with its blunt ram or rostrum at the end of the nose; then Clidastes, a lithe creature and more elegantly built than the other two." "Yes, dear, I have been fortunate in the discovery of complete skel. etons of these fine swimmers. I sent a very beautiful skeleton of a Tylosaur to the Sencken. berg Museum at Frankfurt-on-the-Main. (Fig. 5). Skeletons of Platecarpus to Tubingen University, as well as a Tylosaurus. And one to The Museum of Toronto University, Canada, and another to the Victoria Memorial Museum at Ottawa, Canada. A beantiful Clidastes to Vassar College, New York, a fine head and trunk to Carnegie Museum, at Pittsburg, Pa. The Mosasaurs, you know, all have short necks and long tails. The jaws are armed with recurved teeth and a set on either side in the roof of the mouth near the gullet enable them to hold their prey, so they could not escape if they opened 


\section{The Cretaceous Seas}

their mouths. They had an aid to swallowing their food, by means of a ball and socket hinge in the center of the lower jaws, just behind the tooth-bearing bones. This enabled them to expand the lower jaws and shortening them so as to force the food down the throat."

"See Papa," said Maud, "The rising tide has floated the dead saurian towards the shore." We walked to the beach and our united efforts en. abled us to pull him in. He was a magnificent example of the sea life of his day. I doubt if ever a swimmer excelled this one in speed. The four porrerful paddles and lithe form, and the long tail in constant vibration, enabled him to cut the water like the prow of a racing yacht. His entire body was covered with small scales like those of a diamond rattler, arranged in beautiful colored designs, and highly polished. The scales sparkling in irridescent splendor. "How well poised the head," said Maud. "How large the eyes, protected by sclerotic plates of bone now glazed in death." "Wonderfully beautiful," I answered, "So God creates His creatures, His plants, His crystals. Man's feeble efforts to imitate nature how crude and clumsy.

"I think Maud it would be a good plan to cut off strips of the skin for ropes and sails, and many other useful things. I will make you a hammock of a wide strip." "Very well," she ans. wered, "Let us go to work." While busily engaged, we were covered with moving shadows 
and looking up saw enormous l'terunodonts those glorious flying reptiles, hovering over head. With broad expanded wing, some twenty feet from tip to tip, they swooped downward, or rested in graceful attitudes in mid-air. Their great eyes scanned the ocean before $u$ s for fishes, and when one was discovered dropped like a shot into the bay rapidly reappearing with a fish between their toothless beaks. One aftel another broke the mirror like surface of the deep, and always came to the surface with a fish. Their unerring sight had discovered. No eagle ever dropped quicker on his frightened quarry than these lizards. The scene before us was exciting indeed.

After finishing our labor and stretching the skin of our Mosasaur on the sand to dry we continued our strole along the sand. In a deep hole, we admired a whole colony of the most beautiful swimming crinoids, or sea lillies we had ever seen. They were stemless and floated with the currents of Mosaurian Bay, as I had named the sheet of water on the new map I had made. Their bodies, about the shape of half an egg, with an opening in the center, and ten arms radiating from the margin. These arms were three feet long, with feathered edges. Over the mouth too, were smaller arms used to comb off into the mouth the tiny animal life of the sea, that was strained through, and caught in the meshes of the feathered arms. Mr bors found luundreds of these crinoids in the chalk on Bearer Creek, Kan- 
sas, called Uintacrimus socialis. "We enricherl many Musenms with them.

"Papa," said Mand, "let us go into the woods to escape the heat. It was beginning to be felt, as the sum has climbed orer the trees, and the heat beats upon the dry sands. We first entered a hard and soft wood forest, composed largely of Sassafras, Magnolia, Linden, Birelı in endless variety, Cimnammon, Sweet Gum, and many other of the first trees with heart and bark like our existing forests of the twentieth century. There was a thick nnderbrush of wild roses and aralia vines, with their beantiful three and five lobed dentate leaves. The brooks were lined with r'nshes, and ferns and other familiar regetation. We could see deeper in the forest the stately Redrood in serried ranks, as far as the eye conld reach; colonades of God's first temple. Here in. deed we found the coveted shads. The trunks like Gothic columns lifted their stately forms two hundred feet on high, with densely packed crowns of living green, that cut off the direct rays of the smn. They filtered through like those through stained glass filling the woods with tint. ed and mysterious light. "How grand," I cried, "to live so close to God and His great heart, Na. ture's heart. God is the very embodiment, everywhere of nature, even 'the spacious firmament on high, and all the blue etheral sky, And spangled heaveus a shining frame, there great original proclaim.' There, Mand, do you see the damp 


\section{The Cretaceous Seas}

sand along the river shore. See how the leaves have fallen in it, some lie flat, others with stem down, are half buried; all will be covered with the ocean mud at high tide, there they will remain until pressed by the masses of rock that will be laid down upon the deposit, it will be hardened into sand stone, and the leaf impressions will be preserved for millions of years. Until in the twentieth century, I will dig them from the solid rock in the central plains of Kansas, and Lesquereux and Ward, and Knowlton and Wilson, will identify them."

So we wandered on through mighty aisles in this great temple, where God loved to walk, though all unseen by our mortal eyes, we felt His presence near. "O Papa," cried Maud. "See the ground is strewn with edible acorns. There were no squirrels last winter to store them away. And there are some ripe figs among the green ones in yonder tree. If you will gather the figs, I will, fill my apron with acorns and we will have a new dish for dinner." "All right," I replied and soon gathered a large supply. We carried our treasures home; and while Maud cracked the acorns between two cobble stones, I secured a strong shell for a morter and a rounded stone for a pestle and ground the fruit and nuts together, which we made into little cakes, they with hard boiled turtle eggs made a dinner we enjoyed.

I had scraped a shell full of salt from the face of a precipice where the water of the sea had 


\section{The Cretaceous Seas}

beaten high against it and on evaporating left a thick layer of salt behind. And so the day passed, every moment showing us a new phase of the Creator's handiwork. We soon decided that as the sea life here was so luxuriant, we would build a ship to sail the quiet waters of the Mosasaurian Bay. I succeeded in planning one, with Maud's assistance, that promised safty and comfort. I selected half a dozen straight redwood $\operatorname{logs}$, thirty feet long; burned off the ends and branches. With the aid of fire dug them out, and stretched over them the dried skin of mosasaurs. (Many had been killed in their battles and we had secured their skins). Each compartment was air tight and very bouyant, I rived out boards from the redwood $\operatorname{logs}$, and lashed them across the boats for a platform, on which we built cabins fore and aft, and erected a main mast from which our sails were stretched from yard arms, manipulated with ropes from the same tough hide that we geared as sails. Huge rocks we heaved on deck and attached ropes to them and used them as anchors. We made state rooms, kitchen, and sitting room, amid ship. After many days of labor, we finished our craft, and were ready for life on the ocean wave.

We resolved not to venture far from shore and to cast anchor in some quiet land locked bay at night, Maud was to handle the steering apparatus, while I cared for the sails, Maud cooked dainty morsels from land and sea and bayou. We 
not only got turtle eggs lut the turtles themselves, and a great variety of fishes, mackerel, herring, etc. While building our slip we had un. limited adventures, because each molning and evening we walked off into the forest or explored the sea shore, or walked along the winding river, or mossy bayou. Put as my attention was occupied in the boat building I could not keep notes of these adventures. We named our little ship The Swan, not because of the beauty of the boat, but because it floated as lightly as a swan on the waters of Mosasamrian Bay.

One lorely morning in early . Tune when life was the richest, and the forest had attained perfection; we hoisted oul great square sail, and loosened our rudder bands, and put to sea. With a gentle breeze stirring, and with only a gentle ripple on the bosom of the deep; with no rocky breakers in shore, the motion on board was delightful. "Look Papa," cried Maud, as a great fish, fifteen feet long, dashed by in pursuit of a school of mackerel, that were struggling to get into water to escape his murderous jaws. He was armed with loug conical teeth, tlose in front where the face with its short muzzle looked like a bull dog, the horrid fangs were four inches long; in the center of the head was a triangular crest, that cut the waves like the dorsal spine of a shark. He beat the water into spray, in his eager pursuit of his prey; and many a fish fell a victim to his appetite. His skull was two feet 
long, with powerful lower jaw, his great pectoral fins were over three feet long. The rays had sharp outer edges. He conld set and use them as a sword to gash his enemies, the great white sharks. His forked tail, with span of over four feet, would cause an awful blow when used as a weapon; large glistening scales, covered the entire body. Maud called my attention to the fact that our huge fish had finished breakfast, and was swimming back into the deep water of the bay, quite leisurely, so graceful in motion a living five-horse power-motor boat. "You remember," she said, "the skeleton you sent of this fish to the British Museum." "O yes," I replied, "Mr. Pycraft wrote a description of it for the Illustrat. ed London News, March 1, 1913." (Fig. 4).

"My son George found and collected this fine specimen, I prepared it." "You must be as pleased to see the boys make such noted discoveries," she said. "O yes, because it encourages them to keep at work, in this life work of mine. As a boy I lored nature, I was a hunter too and used to kill buffalo and antelope. But after close association with the most famous Naturalist America has produced, Prof. E. D. Cope of Philadelplia, who often told me that though we must destroy our enemies and protect our friends, as a matter of self protection, yet wanton destruction of life was a crime. The more I thought of this suggestion the more I came to fully believe it. God loves the creatures He lias created and will 
surely punish man for needless destruction of the beautiful birds and fur bearing animals, so they can decorate their own persons, wearing the borrowed plumage, and silky furs of his creatures. I long ago gave up killing wild animals, and for years could say with Goldsmith, "No herds that roam the valley wide to slaughter I condemn, Moved by the power that pities me, I learn to pity them." However as I like meat I am obliged to qualify the stanza by saying, as is reported Goldsmith's wife had said, "No herd that roves the valley wide to slaughter I condemn. The butcher kills the meat for me, I buy the meat of him." In other words I let my sons do the hunting. My great pleasure as you know dear girl, is to dig with pick and shorel from the rock, the animals of the past, to clean and prepare the crumbling bones, and by the power of the imagination breathe into them new life. And has not God shown us His appreciation of this lore we both possess by bringing us back here among His creatures of another day."

"O! Papa!" cried Mand. "See the water is cut by the spines of great sharks twenty-fire feet long. See some are so near the ship in this transparent water that we can see them perfectly." "There," I answered, "is a Portheus they seem to be in pursuit of. That big shark passes immediately under the Portheus. He turns on his back, and his huge mouth opens, look at the many rows of wicked looking teeth. How they 


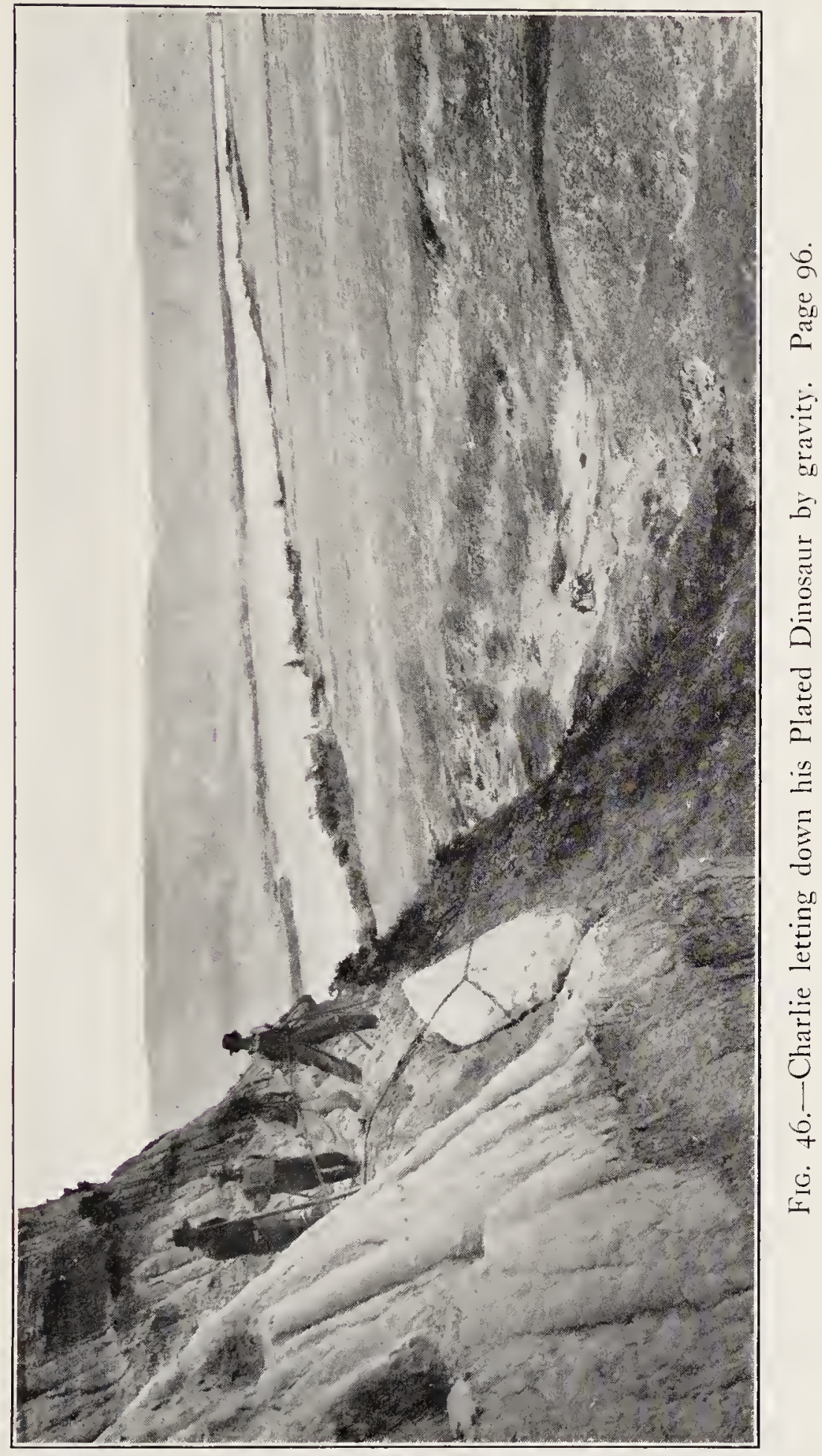




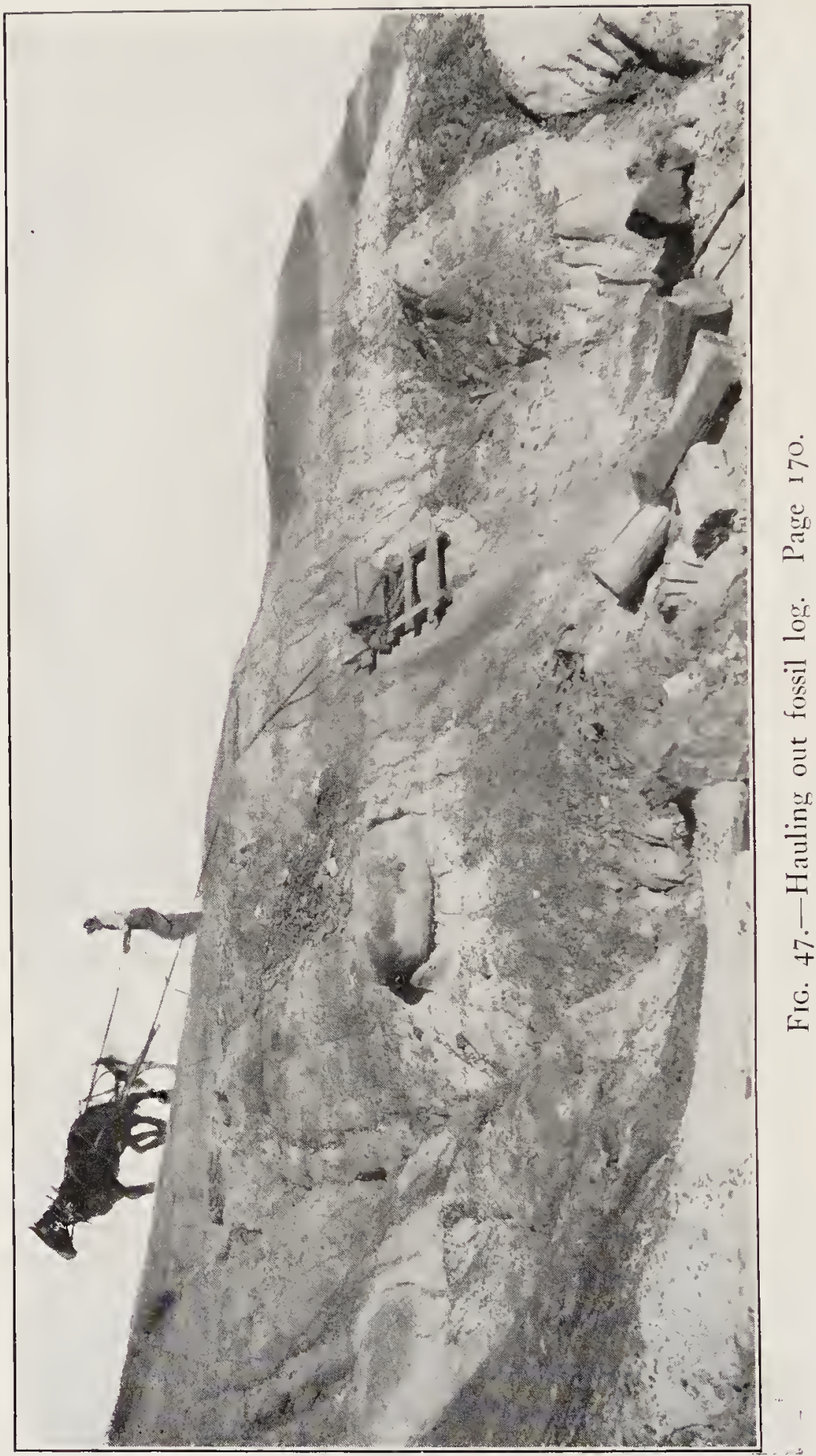




\section{The Cretaceous Seas}

gleam in the light, they are sharp as razors." "See how many different forms of teeth in different parts of the mouth." "Yes dear I remember that in the mouth of one I sent to Munich in 1882, from the Kansas Chalk Dr. Eastman found twenty-fire synonyms, or species that had been described from loose teeth. Watch, there are several other big sharks coming to the assistance of the one who is after the Portheus. We will hoist the sail and try and keep pace with the battle, that surges Nestward, watch the rudder Maud while I loosen the main sail! It bellied to the strengthening breeze, urging on our ship with increasing speed until we were again among them. The Portheus now swimming for life was the foci of the sharks, that were coming to the attack from all directions. One would dive under. the fish, and receive for his pains a stroke from his powerful tail that would put him out of commission, another would receive a thrust from the sword like ray of the front fin. Undaunted, others hurried up like a pack of wolves on a wounded deer. Though many were wounded in the fray our hero fish at last succumbed to numbers, who gashed his body with their lance-like teeth, and the water was tinged with his life blood; weaken and overpowered, he gradually ceased struggling. The sharks gathered to the feast. One however was so badly wounded by the Portheus, that he went to the oozy bottom with him. I have preserved in the Museum of the 
University of Kansas a shark twenty-five feet long, and mingled with his remains were the bones of a Portheus. The evident result of such a combat as we witnessed on Mosasaurian Bay."

We lowered our sail, and drifted idly on the swelling tide, that led towards shore. Maud steered for the mouth of a large river's mouth, and succeeded in getting the boat into deep water under a protecting bank, and we snubbed our ship to some saplings and also cast our anchors over board, as an additional aid to holding the boat in place. I crossed the gang plank, I had connected with the shore, and went off into the woods after berries, for dinner, while Maude cast her fish lines over board, and lighted a fire, I brought home a couple of quarts of raspberries, and found Maud had caught and prepared a nice mess of fishes, that were sizzling over the fire. She soon had a nice meal ready. So the day pass. ed and we early sought our state rooms, I first however, recited a poem I wrote on board a C. P. R. Steamboat, enroute from Port McNickels to Port Arthur in June, 1914:

\section{$\triangle$ LAKE TRIP}

I am riding on the bosom of an inland chain of lakes,

At their glories and their wonders my sluggish soul awakens!

They become the mighty highway of two na. tions strong and brave, 


\section{The Cretaceous Seas}

And the commerce of two peoples are wafted o'er the wave.

On either shore, once planted, (God's ancient temple grand),

The great primaeval forest densely covered all the land,

Man's vandal hand has cut it from the face of mother earth,

To a second growth of timber the land has given birth.

And in this Age of Iron, great freighter's haul the ore,

Across Superior's bosiom to the smelters calling "more"

Ten thousand tons of coal the freighters carry west,

Where the iron ore is loaded for its journey to the east.

I am riding on a Steamer of the C. P.'s mighty fleet.

The keel is riding even as the earth beneath one's feet,

In fact a Floating Palace with all its comforts there.

Its pathways blazed before it for weather rough or fair.

What a glorious prospect now, is opened up to view 
The scenes for ever changing each opening vista new,

See! indentures cut in shoreline by rivers' mouth or bay,

But for the lighted lamps we'd hardly find our way.

At last our boat has entered and rapidly pass. ed through,

The lock of Sault St. Marie, the Frenchmen call the Soo.

Upon the broad Superior our westward course we take

The course the captain chooses, near the center of the lake.

But now a mist is falling that soon becomes a fog.

Our Siren sends her warning o'er many a lengthening rod.

We hear the Fog Horns sounding from near or distant craft,

And just abeam our steamship we hear an answering blast.

We think of Ireland's Empress as she sank beneath the wave,

Which, until God's trump, will be some dear one's grave.

But, God rules on the water, as well as on the land 


\section{The Cretaceous Seas}

We're very full of confidence we're guided by His hand.

So in our narrow state room, we lay us down to rest

And through the long night watches, we jour. ney towards the west,

And when the morn awakes us, the sun is shining bright.

And head land peaks are glowing with streams of early light.

We woke next morning much refreshed as the night had been cool. After breakfast we were ready for the adventures of another day. Drifting out gently on the broad waters of the bay, we were delighted to see a school of Plesiosaurs come sailing in from some distant cruise. These strange sea lizards, with long powerful neck and four paddles, and a mere stump of a tail. They were on a fishing excursion, as the herring and mackeral were now coming in to spawn near shore. These monster saurians swam like a snake bird below the surface, their long necks and heads darted hither and thither above and below exploring a space of forty feet in search of fishes. We could see the flash of shining teeth as a luckless fish was captured. Some of them floated on the surface, and with swan-like neck and body they moved in graceful circles, or sped along at a terrific pace picking up their morning 
meal, from the countless panic stricken fishes, that vainly somght to escape their tooth-almed jaws. I told Maud of a complete skeleton that liad once been found by a farmer in the Kansas chalk of Butte Creek, logan County. He started to excavate a place for a stable when he uncovered some huge vertebrae, and ribs over five feet long. He supposed they were elephant bones, and as they were broken, he thought they could not be saved, and so dug up the bones with the chalk. Thes were dumped into a cow yard and beaten to powder under their fect, and could never be restored. I grieved much over the loss to science of that splendid specimen that has nerer been duplicated. Dr. S. W. Williston, the oldest living American Vertebrate Paleontologist, described the few bones I was able to save from the general wreck. He did me the honor of naming it after me." "Trhat a pity," cried Maud. "It must be terrible for you to learn of such vandalism." "Yes, dear," I replied. "I doubt whether any mortal suffers more from this kind of randalism due entirely to ignorance than $I$. I remember finding some rery large turtles in the Upper Miocene of Phillips County, Kansas, that had been killed evidently by a sand storm, as they were all resting on their carapaces, as if traveling in one direction. I secured over trenty of these land turtles, and among them was the most perfect and beantiful one I have ever collected, although Dr. Weiland of Yale 


\section{The Cretaceous Seas}

University told me that if fire of the most pelfect fossil turtles known, were placed together a conple I sent his museum, wonld rank 2 and 3. I had occasion to photograph this splendid specimen, and had laid it on edge on a deal table. I then went into a carpenter shop for assistance in moring another, too heary for me to handle. When we got to the table the man helping me sprang on it (as he thought he could lift the one the were carrying easier), his weight was so great, it bent the boards on whose further ends the fine specimen was resting, and it came to the floor with a crash. It was broken to pieces so small it could not be saved and restored. So one of these animals so perfect in all human probability it will never be duplicated, was destroved. The loss was terrible for me." "You have had some bitter experiences," said Maud, tears standing in her sympathetic eyes. "Many indeed, Mand," I answered. "But while we have been talking our plesiosaurs have put to sea. Their distant wakes are just visible." "See, papa, what a strange looking fish. What is it do you suppose?" "Maud, that to me is the best armored and most ferocious fish I have ever known. I used to think the man-eating sharks, off the Florida coast were the most blood thirsty of the order, but this one is still worse. Notice the head is prolonged in front into a long round bony snout, or ram. On account of this I called it a snout fish when I first discovered their bones 
in the Kansas chalk. The ram ends, you notice, in a sharp point eight or ten inches long. Then at the end of the mouth are four lance like teeth projecting forward, and outward. The object was for these to cut the breach his ram had made in the quivering flesh of a mosasaur wider, so he could force his head into the bleeding flesh to the eye rims. But his most terrible weapons are his pectoral fins. See, they are four feet long. Serrated on the cutting or outer edge, enameled and sharp as a knife. They can be locked, and stand out straight from the body. A sudden swing would, if he was close to a mosasaur cut a gash several feet long in its vitals. See these fins span orer eight feet. I pity the fish or reptile that comes his way." "Watch, papa!" cried Maud. "There comes a huge shark. He certainly doesn't mean to attack such a well-armed fighter, does he?" "I should not be surprised," I answered. "I believe a shark of this size, at least twenty-five feet long, will attack anything that has life." The shark made a sudden dive under the snout fish, but before he could turn the fish set his right sword-like fin and swinging suddenly to the left made an awful gash into the side of the shark laying open and slashing his vital organs. Relaxing his efforts he sank into the ooze of the ocean bed, followed by the snout fish to feast off his carcase. And so we idly drifted with the currents and study the wondrous fauna of this strange sea and land. 


\section{The Cretaceous Seas}

We see Marsh's loon diving for fishes, and many other birds not known to science. One day while resting from the excessive heat in the shade of a redwood Maud was very tired and soon fell asleep. I, too, leaning against a mossy log, dozed off. 


\section{CHAPTER XIII}

THE WONDERS OF THE PERMLAN

How wonderfully God works in one's life! I must have fallen from the log, for I dreamed, Maud and I had both disappeared into a sluggish lagoon. When I came to my senses, I discovered that I was in a great jungle of vegetation; that belonged to a very early age I recognized the dense forest of many species of Carboniferous Tree Ferns and Tree Rushes; and many species of Cycads. Nearly all the trees were inward growers, with plumes of regetation on top of the scar-marked trunks, from which the leares had already fallen during their growth upward. I knew that only a thin, hard, outer covering protected the pith beneath of most of the trees around me. Although there were pines, the Angiosperms had not yet appeared. Everywhere were dense masses of sponge moss, and moss-like trees.

Lepidodendrons bushy crest

Ware back and forth, together prest;

While sponge-moss hangs in festoons gay

Across the thickly planted way.

The climate was tropical; the heat intense. 


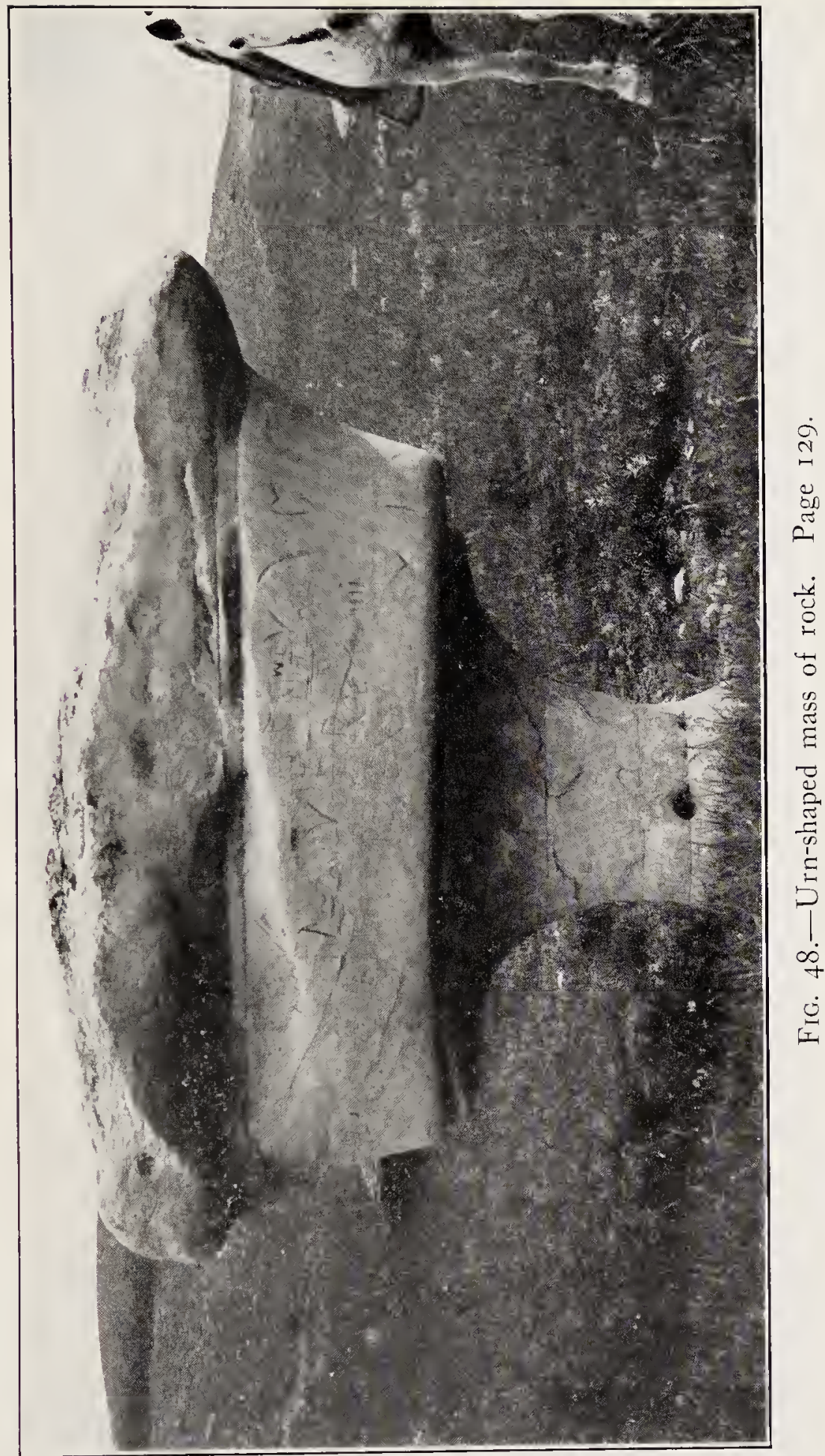




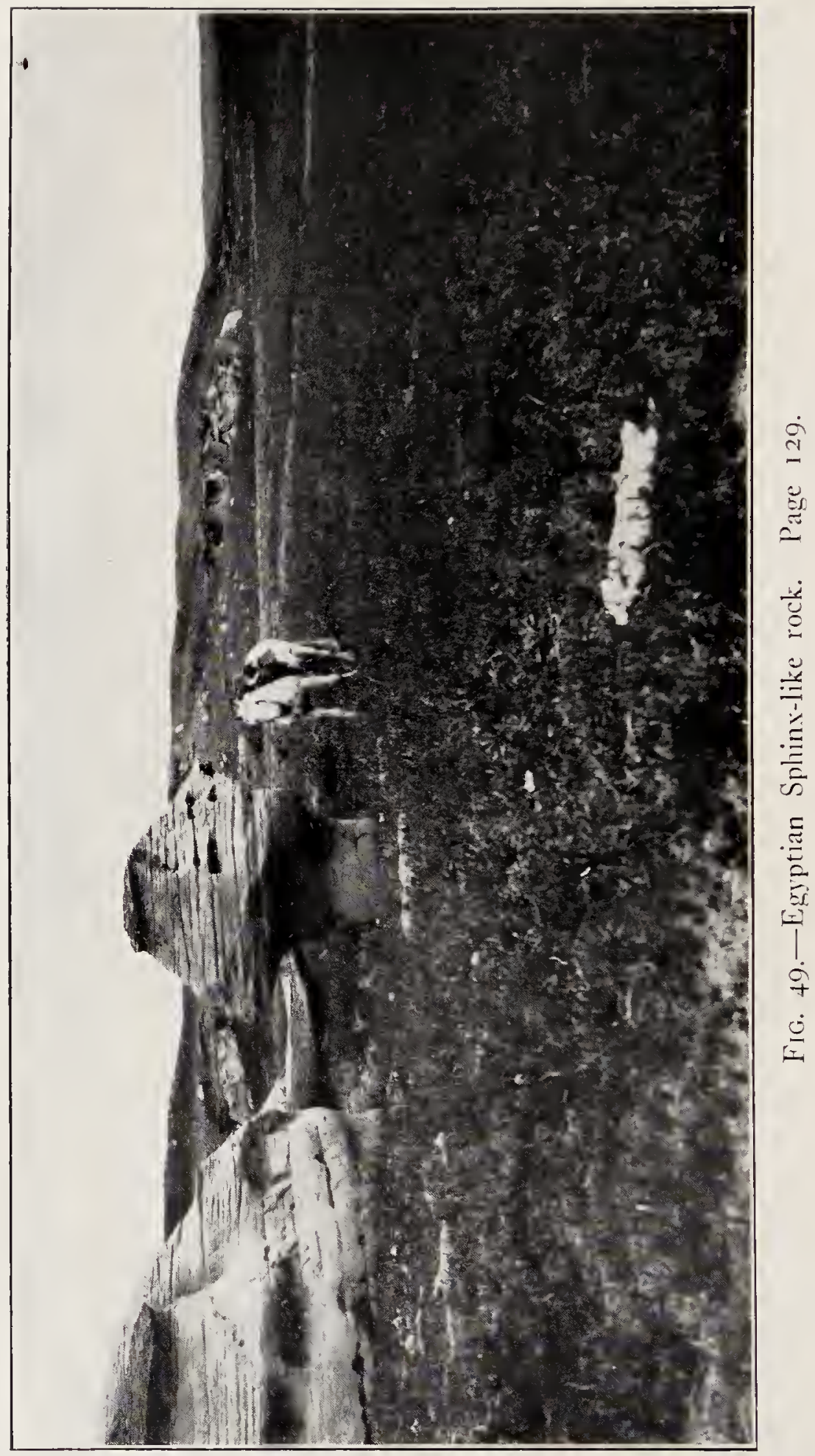




\section{The Wonders of the Permian}

The water was fresh; no sea in sight.

I climbed to the top of a tree fern, from which point of vantage, I had an uninterrupted view of the surrounding conntry; which was one great level streatch of fern plumes, densely intermingled with ancient pines, lepidodendrons, and cycads. The latter resembling gigantic pine apples, with a plume of leaves on top; or with trce-like trumk, and plume of crowded pinniate leaves. These first clung closer to the ground. While the others sought the direct sunlight perhaps fifty feet abore. From my field of vision, these vast masses of the most delicate foliage imaginable, moved by the gentle breeze in gentle undulations, with only here and there a break in their carpet-like compactness. While swinging below, as I have already noted, were hanging mosses in various hues. The ground densely corered with sponge-moss. In the lower places pools of water into which the moss extended often completely covering them, a land of treacherous bogs. One must watch his footing as I soon proved, by cutting a rush whose length was orer twenty-five feet, and pushed it easily down into one of these small moss-ponds, through the peat and failed to reach the bottom, I realized how easily one might lose his footing, and slip into one of these mossy swamps and disappear.

And another thought came to me of the won. derful bone-bed Miller found along the Big Wichita in Texas, in 1909 where many complete skele- 


\section{The Wonders of the Permian}

tons covering a space six or seven feet wide, ten or twelve feet long and two feet thick. In this limited interval, according to Dr. S. W. Williston, who has been so fortunate as to study the material secured by Miller were dozens of complete skeletons packed like sardines in a box of the wonderful fauna of the Pemian of Texas.

From a slight observation of the flora of the region into which we had been miraculously transplanted, it had convinced me that I had gone back from the twentieth centuly some twelve million years to the close of the Carboniferous, that great age of Coal Plants, when vast regions packed with the moss and other vegetation had been engulfed in the sea, and after ages converted into coal.

So, how easily it was for me to realize that one of these lovely moss covered pools, might prove a death-trap to any animal whose spoor lay through this region. It was lucky for me that I still possessed a Marsh pick with its broad duckbilled end, with which I could easily hew my way through the dense but easily felled trees and rushes, that obstructed in jungles of regetation my progress. I judged that the open spaces I saw in the distance from my lookout in the crown of a tree-fern, must represent ponds or lakes and there, would be by far a better place to study the fauna of this strange region, because I knew from my own discoveries in the Permian of Texas that many of the vertebrates were Amphi- 
bians who lived in the water or the land as pleased their fancy.

As I knew I would like to return to the place where I first awoke to the realities of life, and from past experiences Maud was likely to appear near here too. My first act after sliding down from the tree was to direst myself of all my clothing except a pair of shoes a pair of pants, and a woolen shirt and light hat, with a broad rim I had worn so long. On account of the moist climate and thick regetation, the air was inavy with carbonic acid gas. The only place where fresh winds were blowing and the air was rich in oxygen, was on top of the forests, or as I hoped along some lake-shore where the winds of heaven would be able to ripple the waters at least. So ready armed with my pick to cut a pathway or defend myself from some hungry amphibian or reptile because I expected to find amphibians with huge heads, and bodies larger than my own, armed with terrible teeth. It seemed strange too, that though in the twentieth century the order to which these giants belonged, frogs and salamander were ready to disappear. Here they were the dominant trpe so abundant that the Permian Age has been called the Age of Amphibian or Batracians, I found the work fatiguing on account of the great heat and close and oppressive atmosphere, that constantly seemed to be on me to take a nap, yet with the power man has over material and sensual things, I cut a path-way 


\section{The Wonders of the Permian}

broad enough for two to walk in it side by side, I knew if llaud was discovered, she would want not to follow me like an Indian in single file, but beside me. I often stopped to listen, as I rapidly progressed toward one of the open spaces I had noted from the tree, because born on the slight breeze that rustled the leares above me, I could hear the croaking of frogs that grew louder and louder, the sound put me in mind of a lot of frogs singing through a megaphone. Suddenly without warning, I cut through the jungle and found myself facing an inland lake of fresh water bordered in places with reeds and rushes and moss that reached into the water.

At another place near where I caught my first view of the waters, was a sandy beach. Peopled with life, both reptiles and batracians were ererywhere. The great Salamander Eryops of Cope of which I had secured so much material in the Red Beds of the Big Wichita River in Texas both for Cope, Zittel and Von Hume, swam in the waters before me or measured their six feet of length upon the sand. The frog like noise I concluded came from these liuge monarchs of the Amplibians. I could see them resting on logs that were half submerged in the water, or swimming below the water; lying on the bottom or crawling along the shore. Emerging from the jungle that fringed the lake on the further margin from me were strange reptiles. One I noticed in particular was the largest of his tribe we were 
likely to see here. I say we because I could not believe that He who had brought Maud and me through so many adventures would take her bright presence away forever. These thoughts were in my mind as I watched a reptile come into full view out of the jungle.

The most wonderful thing about him, was that he carried on his back an enormous hump. The spines in the center of the column were at least three feet ligh, and packed around the base were masses of muscle and ligaments, tapering to a sharp point at the top of the spine. A cross section would be wedge shaped. I learned afterwards from a study of the skeleton, that as the centra of the rertebrae were very weak they were held firmly in place by the crossing ligaments that were wound around the centra and spines in intermingled masses. This creature had come out of the jungle for water interested me greatly. He was about ten feet long from head to the long end of the delicate tail. I was surprised to see him suddenly dive back into the jungle with all the speed at his command. The Eryops too suddenly stopped croaking and a nerve wrecking silence, covered me as with a pall. The reptiles and amphibians sought refuge in the jungle of the bottom of the lake. And that body of water but a second before so full of life and activity lay a mirror, silent as the grave, looking in the direction from which neither reptile or amphibian had run for shelter, I heard too, an unaccustomed 


\section{The Wonders of the Permian}

sound in these swamps and everglades, it sounded very much like the cutting of trees I could hear the crush of mingled vegetation as if a tree fern had been felled at one strong blow and it came sliding down against the thickly planted vegeta. tion, I could hear the swish as it was dragged away, to make room for another that quickly fell. Yes! I could hear human voices I was sure, and soon I heard wafted across the lake the loved name Maud. I could see the trees swaying, and then one by one come down in a straight line for the lake, and I knew that in these solitudes I was not alone. That God had brought others to this young earth. Whose surface still felt the subterraneous heat, whose crust was so thin it often sank into the sea or was raised just above high tide. I sprang forward on the beach to the water's edge just as the last obstruction in the shape of a trunked cycad with its tangled mass of leaflets crushed to the earth and behind the ambuscade of regetation stood my whole family from Manma to Levi, and close beside him was Maud. George and Charlie were the ones who welded their picks, Mabel and Myrtle and the children and the others dragged the trees away and they had their hands on the cycad when they suddenly beheld me standing petrified on the beach. Such a shout went up was never heard before. I waved my pick speechless with surprise, for once at least in my life, as you have all 
found out my dear readers, as my father used to say "I talk too much."

All at once I recorered the use of my organs of speech and shouted: "Why don't you come over." They all waved branches of the palm like cycad they had torn from its head, as they shouted back: "Thhy don't you come overg"" Well it did appear to me that it would be easier for me to cross the smooth waters than such a crowd. So trimming off the plumes from a mass of cycad and tree ferns, I soon had enough trunks to build me a raft, I lashed them together with the mid ribs of the cycad leaflets, which proved as strong and pliable as buck-skin thongs. In a very few minutes I had a raft that floated like a cork, as the centers of the trunks were full of pith. We afterwards found this pith was quite starchy and made very acceptable sago flour. In the mean time, the party on the other shore had erected huts covered mith leares above, and open below so the wind might circulate through them and the roofs would not only deflect the ardent heat of the sun but protect us from torrential rains with a reed for a paddle I sprang on my raft and soon ferried across to $\mathrm{my}$ beloved ones, I had never expected to meet in the Permiam at least. Of course I was delighted to find Maud.

After our greetings they gathered in affection. ate groups under the trees and told me of their experiences since we last met. Mamma said after 
I disappeared so suddenly and mysteriously from my home in Lawrence, she had induced George and Charlie to move their families into the home nest, from which they had taken flight. She had imagined all kinds of things, and even the Govermment had missed their fossil huntel and had cxhausted the resources of the Detective Division as well as that of the United States in the en. deavor to locate me, but I had disappeared as effectually as if the earth had opened her mouth and swallowed me up. Only day before yesterday Levi suddenly disappeared, and left her in a terrible state of suspence as to what it all meant. Last night she had a family council with Greorge and Charlie and their wives. They went over the same old ground again and again and were no nearer solving the perplexing problems than at first. The children had been sent to bed and there were rocking chairs enough to go round in which the grown ups were seated comfortably. Mamma she told me, was the first to doze off and Charlie soon followed suit. The girls and George smiled over the others, but before they realized it they too, had dropped off. George was the first one to wake with a start. He could hardly believe his senses. They were in a dense forest of tree ferns, in fact only a few miles from where I was at the time. They were all there but Levi, and as George's surprised exclamation woke them all they heard a rustling noise in the edge of a little clearing and before they could sar a word Levi 


\section{The Wonders of the Permian}

broke through the jungle with Maud clinging to his arm. "Well," Mamma said, "ask Maud to tell the rest of the story." Which I gladly did. It seems, that as Maud had been through a lengthy experience in the Ancient World, she had become a leader. "Well Papa," she remarked, "you renember" when we disappeared in the water" of the Lagoon, I lost all consciousness, but came to my senses in this jungle. My first thought was of course another proridential occurrence. I could hear what seemed the bellowing of great frogs and strange sounds my ears had never listened to bebor'e. I wondered where you could be, and was so anxious to find you, that I could not stand it, remaining there all alone in this strange country, so I plunged madly on, forcing the thick stems and trunks apart and squeezing through them, I called to you too, "papa, papa, where are you!" I could not see an inch ahead for the vegetation. The moss tangled in my hair that fell down and I must have looked a perfect fright. I came suddenly on a clear space only a couple of yards across, corered with the lovliest moss you could imagine. I sprang into the very middle of it in me haste, and broke through and began to sink. I screamed, 'Papa, Papa,' and threw out my arms toward the other side when suddenly I saw two human hands spring out of the jungle and grasp mine, and strong arms drew me bodily out of the treacherous pit, I stood beside smiling brother Levi. He told me that he had gone to sleep in his 


\section{The Wonders of the Permian}

room at home in Lawrence and had awakened here the day before and that he had wandered around in an almost dazed condition. Erery thing so strange. He could not tell what to make of it. I then told him our experiences together in the other ages and regions we had explored, of our boat on Mosasaurian Bay, and the many adventures we had enjoyed together and expressed the belief that we would soon find you and we started on the quest. Levi had his pick and cut a way while I dragged out the trees he felled and piled them in the thick jungle. We had not gone a great ways, when we suddenly heard a shout in front of us. 'That is George I know' cried Levi, 'I recognize his voice,' and he raised an answering shout that made the very leaves tremble. We soon reached him and there was Mamma and all the rest of our family. It was a joyful meeting but Mamma would not allow us to remain there talking of our wonderful experience because she was sure you could not be far off. As the boys had their picks they cut a broad path while the rest of us pulled the light trees out of the way and we were progressing famously when we saw your astonished face across the narrow lake." I could only thank God that I had been reunited with my people and that Maud also was there. It would have seemed terrible to remember her sinking into the treacheous lagoon, then suddenly find myself separated from it by millions of years. Ethel and little Raymond had gone off 


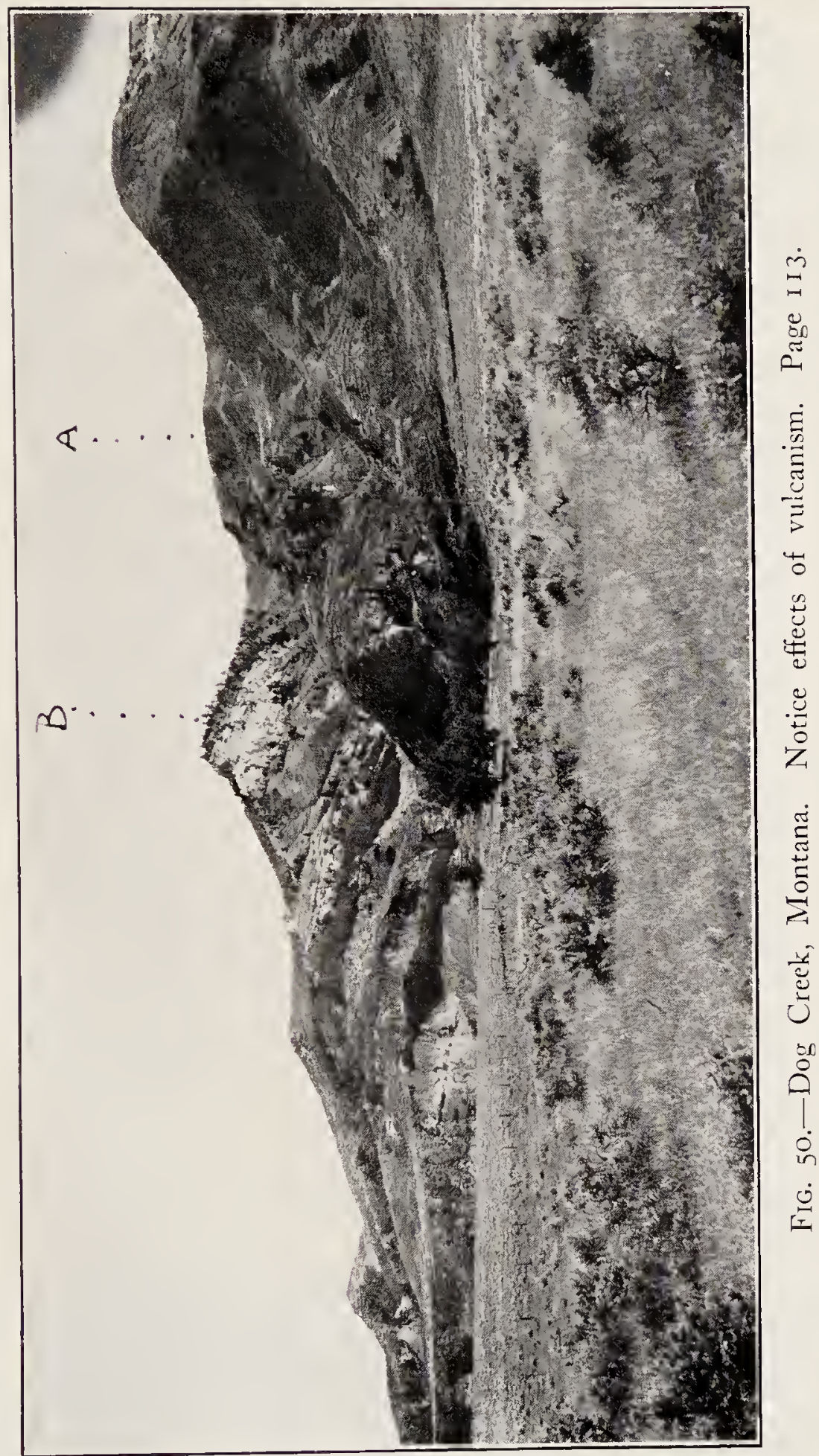




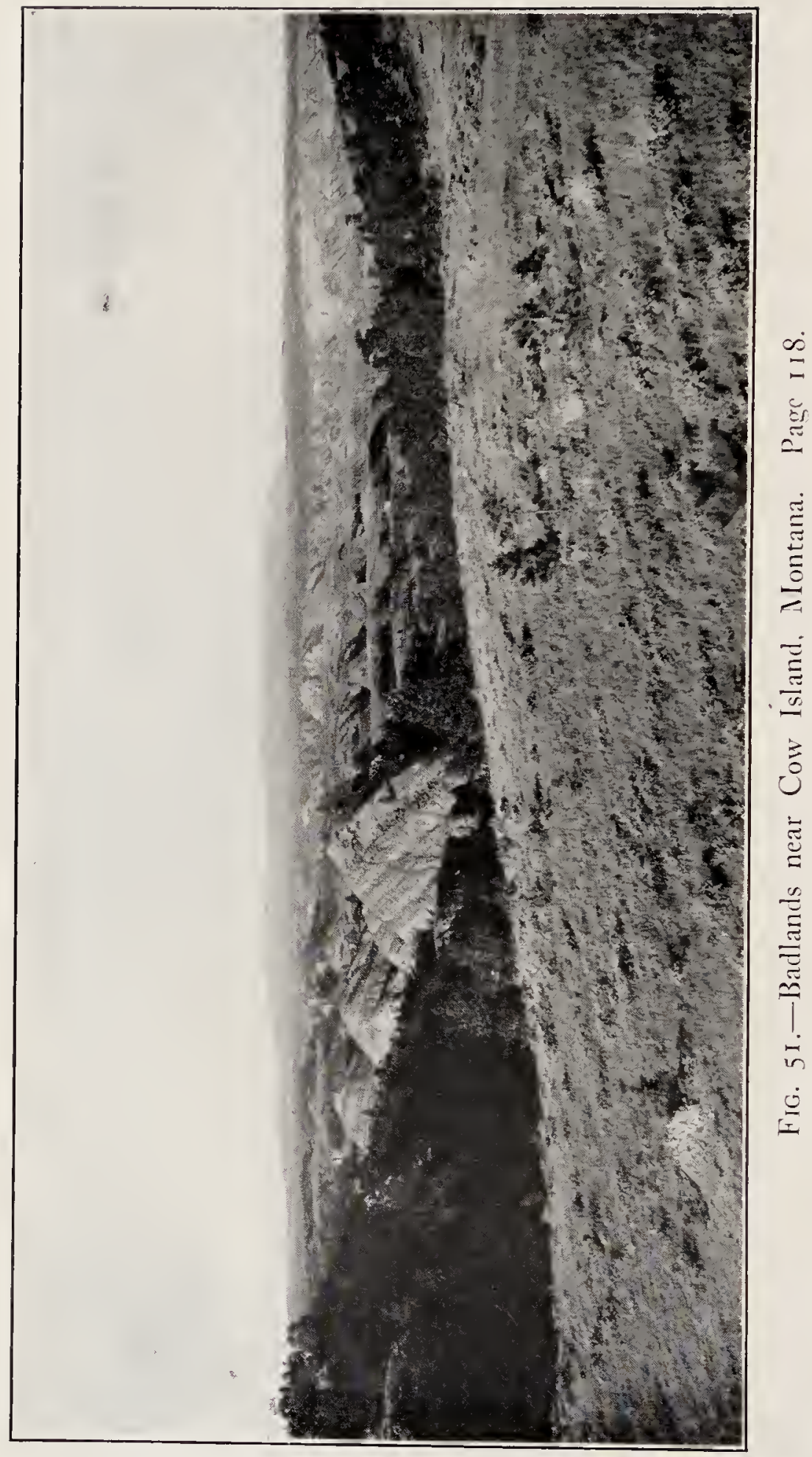




\section{The Wonders of the Permian}

to the sandy beach to play in the sand and Charlie too. They romped until they were tired and Ethel returned to Mabel and asked her if dinner was ready. We had not thought of it. But had been so excited at our reunion, after so many weeks, so much occupied with our talk, that we forgot to be hungry. Just before the family council had gone to sleep George had been at work inventing some cooking utensils, and had not only made diagrams of them but had secured some sheets of alumnium. He had put them in his collecting bag along with the usual tools he carried in the field, and when he woke with the rest of the family he still had them. So I told him if he would make a cooking kettle I would get something to put in it for dinner. Maud knowing the resources of a forest better than the others gathered some dry sticks and Levi by her advice cut some crotched sticks he drove in the earth, and a cross stick to swing the kettle on. George soon found a round water worn cobblestone on the beach to use as a mold and hammered a sheet of aluminum around it, and soon had a pot ready. He cut off a narrow strip for a handle and punched holes in the upper rim to fasten it to. In the meantime I wove together a lot of leaves and made a tray, which I took to one of the cycad stumps (we had cut off the trunk). Then with my pick scraped out a quantity of the pith that fell as white powder into the tray. On my return Maud had the water boiling 


\section{The Wonders of the Permian}

and we stirred in sago flour and as soon as it thickened into porridge it was ready for a lot of liungry mouths. Clialie had made some spoons, so with the pot in the midst we thanked our heavenly Itather for the food from his liand and the glad remnion in the Old Permian of Texas. After a hearty meal we planned for the future. Resolving to thoroughly explore the jungle and try and reach tidewater; as we felt sure the old Permiam ocean was not far away. After our excited roices liad reached quiet and ordinary tones, we were pleased to see the Amphibians and reptiles come out on the beach. One of the most abundant was Labidosaurus an Amphibian like reptile about three feet long. It had short legs and an enormous head compared with its length. I remember a quarry of these reptiles I discorered on the west fork of Coffee Creek in Baylor County, Texas. I found sereral fine skulls for the late Professor Cope, and later by digging into the greenish sandstone, I secured a number more for Dr. Von Zittel of Municl. Another reptile appeared from the edge of the jungle that so closely resembles a South American lizard of the twentieth century, it was called Varanus, by Dr. Broili. It was about four feet in length, had a long head, delicate lizard-like tail. Still another form soon attracted our attention coming from across the narrow pond out of the woods. It was about four feet long, had strong limbs and short head with many small teeth. The giant 


\section{The Wonders of the Permian}

amphibian Eryops too, soon found the courage to come out of the water and start his unmelodious croak to be soon answered by a friendly fellow in the distance. So the life and noises of the quiet jungle took up the accustomed tenor of their ways. The children clapped their hands and shouted when a new form appeared, as delighted as if a menagerie were on the tapis, and all the family were deeply interested. I had the boys drive rush stakes into the ground around our clearings, so as to protect us from the inroads of the big reptiles and amphibians, and admit the air freely. We needed all of that we could possibly get. So we passed the day and night fall found us all gathered in our enclosure listening to the strange noises around us. We had already arranged huts for the entire party and after reading a chapter (for Mamma had her Bible with her) we offered our evening prayers and went to restful sleep. In the morning we were early astir. It was no need to warn the younger men and women to beware of the treacherous bogs as they already had learned of Maud's adventure. We made another appetising dish from the sago flour and I caught some little reptiles not over eight inches long and gar-pike. We fried these in their rich grease, and with the sago mush, had an excellent breakfast. The presence of my beloved family added much to my own pleasure.

My feeble pen would fail to describe the beanty 
of the Tree Fern and Cycad forest. The enormous fronds of fern leaflets that crowned the marked trunks around us, put me in mind of the Australian Tree Ferns in the Carnegie Conservatories at Pittsburgh, Pennsylvania. Only they were much larger and the massive fern branches formed larger crowns. There was such a wealth of variety here too that delighted me. All were lost in wonder at the strange scenery and life, both in its flora and fauna. We determined to cut our way in a southerly direction as I felt sure I scented the distant sea. Charlie and myself using our picks, cut a wide swath of ferns and cycads and other carboniferous trees. Our women folks hauling them out of the way. We were constantly coming across the strange reptilian and amphibian life of that far away day, and our exclamations of surprise at the beauty of this ancient forest came involuntarily from our lips. The moss too, in many gorgeous colors, and hues carpeted the damp ground beneath our feet, or hung in tapestry-like folds from the branches overhead. Many hands made rapid progress and though the heat was excessive we all perspired freely. We often came across the bogs of great extent, ponds and lakes bordered with peat moss, and saw countless reptiles on shore or amphibians in the water. With the earnest hope that we might reach salt water, we labored on under the glaring sun above, that penetrated the thick 


\section{The Wonders of the Permian}

vegetation and as we opened the way, the heat was very trying on our unprotected heads. At last a stroug breeze began to sweep the crowns of verdure above us into great billows, making music among the delicate branches, and I was sure we were reaching the open sea. So Charlie climbed the trunk of a tall fern and when he got to the strong bases of the ferms he stood erect on them and shouted, "There it is to the south ;" for as he told us, a great ocean lay before him as far as his eyes could reach. So with renewed courage we hurried on and before dark broke through the dense jungles we had been traveling through, on the beach, and into a strong wind that was blowing from the south and curling the waves into swaying masses. It was indeed a glorious sight and we all rushed down and ran into the curling breakers near shore and let them roll over us. Thoroughly refreshed, we returned to the edge of the jungle and went to work building shelters for the whole family. We were delighted when George and Charlie brought us a mess of fishes, sturgeon-like in appearance, which, with the cycad flour, the women got up a fine meal. Levi and Maud came in later and we enjoyed an appetising meal. While we were resting after supper and watching the boundless sea, I recited some of the poems I had written. The first one in honor of Jennie McKee's wedding day. She had been a very dear friend indeed: 


\section{The Wonders of the Permian}

O! Jennie McKee,
I am thinking of thee,
My heart beating time
With that heart of thine.
How I hope, and I pray,
That your wedding day,
May be a day of the greatest joy,
A day of pleasure without alloy.

II.

o! Jennie McKee,

I am longing with thee, That the future for you

May never be blue,

And like birds on the wing

You ever may sing.

That your dear life may be blest,

Full of joy and of rest.

\section{III.}

O! Jennie McKee,

Your heart once so free,

Bound in fetters of love.

May God bless from above:

Two hearts beat as one,

While your course you will r'un,

In currents both peaceful and sweet,

Until golden shores you will meet. 


\author{
IV. \\ O ! Jennie McKee, \\ My thoughts turn to thee. \\ And days that have flown \\ Since you, I have known \\ To the man of your choice \\ . And I well may rejoice, \\ For you give all a woman can give, \\ Your love, and yourself while you live.
}

O! Jennie McKee,

V.

Contentment for thee,

In the home you will make,

In the lore you awake,

In the strong heart and true,

Who has pledged all to you,

Fill that home full of love

A forecast of mansions above.

\title{
VI.
}

O! Jennie McKee,

God's blessings on thee!

Like Mary of yore,

Nay He sit at your door.

0 ! sit at His feet,

Learn wisclom so sweet,

That will bless you as long as you live,

While to Him your best service you give. 
198 The Wonders of the Permian

The children had gone to bed and our camp fire of dry fern stumps burned brightly, or faded away as Levi and Maud replenished it. At last worn out with the excessive heat and labor we all retiled to our respective huts. We were soon lost in sleep. When the Amphibians greeted the rising sun with their chorus of what to us seemed like discordant notes (doubtless they were melodious to the natives of these early wilds where foot of man had never trod before). The human element stirred themselves, and after breakfast we all wandered down to the beach for an early plunge. Te dried our salty clothes by running or walking along the level sandy shore.

Maud had called our attention, in a land locked bay to a fleet of Ammonites. Those lovely nautilus-like chambered shells, who had spread their transparent sails to the morning breeze. Some were enormous, orer tro feet in diameter, and resembled luge cornucopias. They floated as lightly and as elegantly as a flock of swans. They were arlayed in all the colors of the rainbow. We could also sec fishes, all clad in armor of enameled scales, in many a lovely hue, garpike and sturgeon werc among the most common. The bony fishes did not appear until the Cretaceous Age, you remember.

What the children loved to do most was to dig in the sand or hunt for the nests of small reptiles, six or eight inches long, that often lay coiled a few inches below the surface, their heads 


\section{The Wonders of the Permian 199}

could enter mamma's silver thimble. My parties found many of them in the Red Permian Beds of Baylor County, Texas. As the sun rose higher the children became drowsy and we returned te our huts and laid them down in some soft fern leaflets that made a bed as light as eider down. We talked of our wonderful adventures in quiet tones, so as not to disturb them, and before we knew it, we too, had fallen asleep. 


\title{
CHAPTER XIV
}

\author{
CONCLUSION
}

Last May I resigned my position as collector and preparator for the Geological Survey of Canada. And soon afterwards went into the field for the British Museum of Natural History, London. Though the British government was spending no money in this kind of research. Dr. A. Smith Woodward, Keeper of Geology there, secured the means for the first two months' work from The Sladin Memorial Fund of Piccadilly, London. My son, Levi, was the only expert col. lector. I had with me though I employed men and transportation in the field. We settled down in a camp a couple of miles below Stereville and renuained there all summer, exploring the badlands near the mouth of Berry Creek.

Our snccess was as usual, great. We were able to collect three skeletons of duckbilled dinosaurs of the genus Corythosaurus, of Brown or Stephanosaurus, of Lambe. They were all three discovered by my son, Levi, who worked with remarkable persistence and enthusiasm. I too, after I had recovered from an injury I received due to being thrown from my wagon onto the ground, put in every moment I could see, in the heavy work of excavating three skeletons, and 


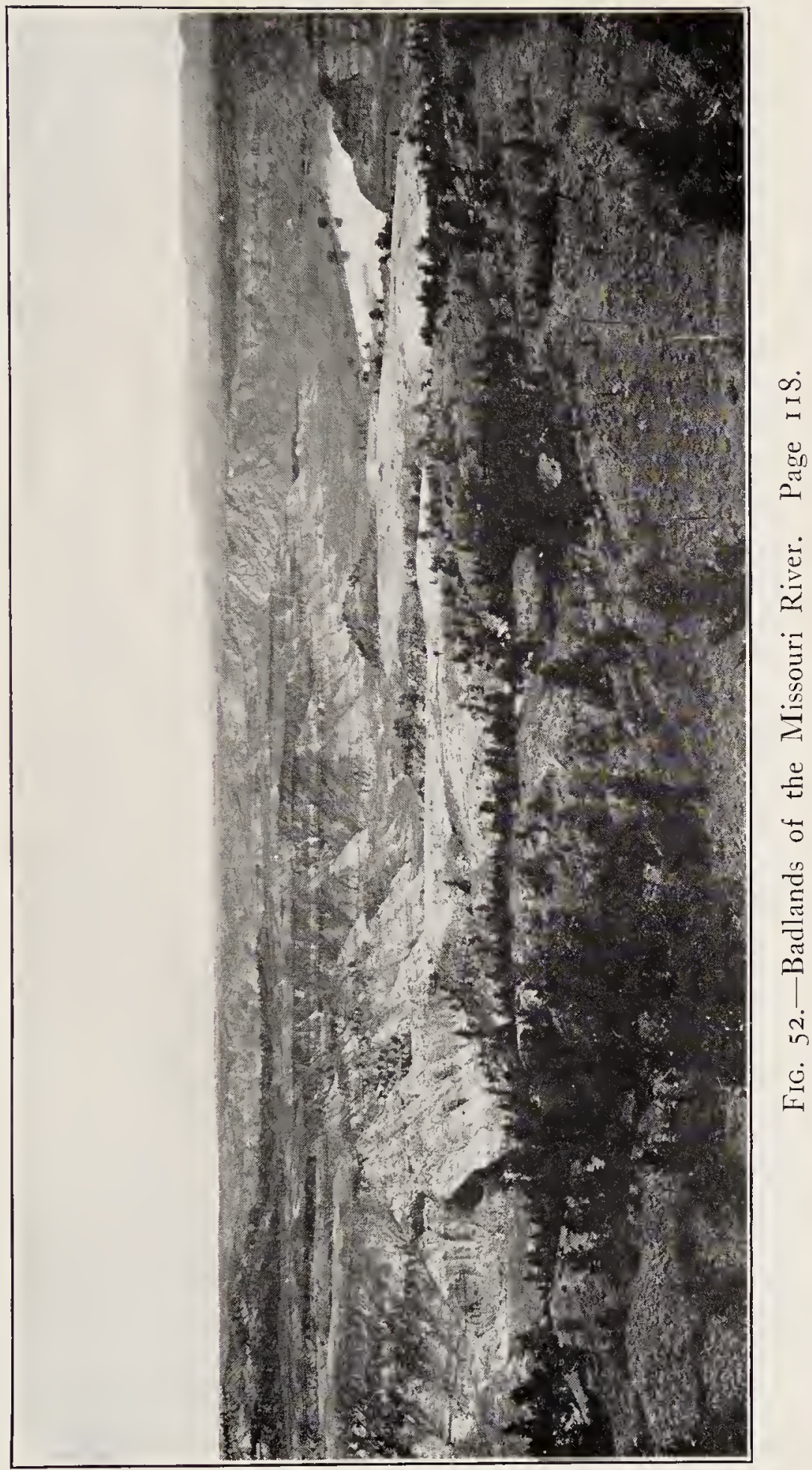



taking them up before frost, when no man can work in those beds. It will not do to let plaster freeze, and without plaster we conld not take up any vertebrate fossil there.

Owing to the fact that the clay in the strata prevent water entering it, very little true petrifi. cation has taken place. If you will refer to the Life of a Fossil Hunter, page 258, you will see there what I had learned up to the time of writing, the process by which fossils are made. I ing, of the process by which fossils are made. I all fossils. I found here in the Belly River Series entirely different conditions. The bones had not been replaced by silica and become petrified. There was very little change in the bones except that they were usually sheatled in a hard layer of bog-iron. The spongy bone was as friable as that in a dry, recent bone; the cells were not filled with rocky material. The thin outer layer of compact bone was filled with the iron simply. I once said that if I could get my teeth on a fossil bone I could tell its age almost, by the amount of silica it contained. Here, however, I find that nature has more than one way of preserving her records, and that it depends largely on the matrix in which the bones are entombed. If clay prevents water passing through the bones, there can be no true replacement, as water is the vehicle used in transporting silica or lime or whatever the petrifying material may be, and it cannot pass through certain clays. This dis. 
covery of mine after having observed the fossilized animals and plants of many horizons prove that the most careful observer is liable to misinterpret the workings of nature, showing us that God's laws are past finding out by finite minds. Nature is a well that man can never fathom, an ocean with no shore. As long as men observe and think, they will be drawing water from wel! and ocean with no risible effect. The well will still be full and the shores remain unexplored.

Levi found the most complete skeleton of a crested duckbilled dinosaur that had been discovered in the Belly River Series by my party. Mr. Brown discovered, close to the Steveville Ferry, the nost complete one known, and which he has fully described in his Corythosaurus casuarius, Bulletin of the American Museum of Natural History, New York, November 2nd, 1916. This is the first specimen ever found in a swimming pose. As if in the very act of swimming it had died and was instantly covered up in the soft mud and never disturbed until Brown's pick revealed it to the world. I firmly believe as I have said before, this specimen proves conclusively that the conventional pose taken of these duckbills as usually standing on land erect is a mistake; as I have always believed. The one I prepared for the Victoria Museum proves the same thing, and every one I have seen in the beds, or have found myself. point the same way, but as it will be a costly 
thing to take down all the mounts in American Museums of Cretaceous tracodonts I do not expect to live to see my views universally put in practice.

This specimen, No. 9, I wrote of to Dr. Woodward, August 21st, 1913: "I have uncovered enough of the floor to be able to give you some valuable information. I have now traced the entire column, except four feet of the caudal region. I have found one femur in position with its tibia and fibula, one lumerus and front foot, and many ribs. The most disappointing thing: we have only found tlie mandibles and predentary, the maxilla of one side, the occiput and part of the crest and the back of the skull."

Later we found the entire skeleton except four feet of the tail just back of the pelvic arch, where it liad been weatlered out and destroyed, and part of the skull. This skeleton was about thirty feet long, and I considered it next in perfection to that of Mr. Brown's Corythosaurus. There were in addition large patches of the skin impression. I show you the place where the body lay, after we had wrapped it. It also shows the vast amount of labor required to save it.

It lay up a narrow gorge, too narrow to get a horse up it. We were obliged to cut steps up and down the rough way from the nearest point we could reach it from camp and Levi had to carry nearly all the water, plaster, and burlap, and paper, etc., necessary to wrap a skeleton 
nearly thirty feet long. The distance from the wagon was nearly an eighth of a mile.

But that labor sank into insignificance compared to the labor he had to strap beneath the specimen his burlap strips in such a way that the rock did not fall out. It would often take him many minutes before he could get the strip" to stick. He lay on his back and patted the plaster soaked burlap with the ends of his fingers until the blood came. Then often the plaster would harden before he could get it to stick. Then he had to take a new strip and go through the same hard and patience-trying labor, filling his eyes with the burning lime. In all the labor we do in taking up a complete skeleton, there is no part of it that requires so much patience and so much skill as straping the under side.

After this specimen was ready for hauling out of the brakes we had to build a sled road to it from the prairie and haul it to camp around the badlands, about six miles, while it only lay about a mile from camp in a bee-line.

Now it seems almost incredible that after over two months of such exhausting mental, physical and soul-trying labor, it should be sent to the bottom of the Atlantic Ocean by a German Raider on English Commerce. If anything on earth can prove the wantonness of such destruction, this is a good example. I have given fifty years freely to science without money, often, and without price. The best that is in me. So I 


\section{Conclusion}

could show to generations to come the wonderful works of God in creation. Ten minutes of vandalism destroys all my labor, my hopes, my life almost, because I nevel can recover from such a blow as this. I have not told the full story yet, because the second specimen Levi found was in many respects better than this one I have described. It was in splendid matrix. A strong sandstone, and the bones beautifully preserved, a specimen that could have been easily prepared. One hind foot was all that was exposed. I could not believe that this meant anything, but a few loose bones. It pointed heavenward, from the side of a cliff. We followed the foot down to the body and found the entire skeleton except a few inches of the tail and THE HEAD. With a restored head, (and we found one that could have been used ) as far as the public was concerned, the British Museum could hare mounted these two lords of the ancient bayous in that great store house of treasures, more rare than gold or silver, to be the heritage of the ages still to come.

This too, was with the first one and went to the bottom, with the Mount Temple and as far as I could learn, all on board. Perhaps some time when the sea will give up her dead, these noble examples of God's handiwork may also be exposed to the light of day once more. I considered from erery standpoint, money or science, these two specimens were worth double what the first two months of labor yielded up. I never 
entered the Victoria Memorial Museum where we had mounted one of the noble duckbills without a feeling of awe, as if I stood in the presence of God himself. It dominates everything in the Museum, and attracts the attention of the dullest of men. How happy I was in the thought that for countless thousands of years to come, others could feel that same feeling of reverence for the Creator. In the twinkling of an eye the blue Atlantic covered them. I once prepared the skeleton of a Megatherium from Brazil; it too had gone to the bottom of the ocean, but divers had rescued it from its watery grave. I have little hope that this will ever be done to the noble duckbills who were sent to Davies Locker by a German torpedo.

We discovered other fine material that was saved and the preparators are at work on it, so I hope our last year's labor, the most strenuous for many years may not be entirely lost.

My dear readers my book is coming to a close. The other volume "The Life of a Fossil Hunter" is out of print. It depends on you whether we have another edition published. This I will gladly do, if each reader of this one, will send me a subscription for the other. You will certainly realize that this work, like the other has been a labor of love. Take this volume, I am at my own personal expense issuing five hundred copies. If I sell each copy I will not realize any more than the cost of publication. I work- 
ed all last winter from 7 p. m. to 10 p. m. on the manuscript, and all day Saturday of each week, except Sunday. It has taken me all winter to look after the printing of this. My whole object has been to give the information I have acquired through years of toil and hardship in the desolate fossil fields to the public, so they may realize something of the wonders of Nature, and the hope it may lead some of my readers to Nature's God, the Triune God we worship. 
THE GRANI CANYON OF THE ROCKY MOUNTAINS

I have often heard the story

Of that Mighty Canyon Grand;

Powell pointed out the glory

of that deeply sculptured land.

Where the Colorado river

Has cut a passage deep,

In the very heart of nature,

With many gorges deep.

To any doubting Thomas,

It would almost make him smile,

If I told him of a canyon

Cut through earth's crust a mile.

But my own two ejes hare seen it,

And I'll take the witness stand,

Its the greatest ditch in story

In our own historic land.

It seems, during the Jura

The land began to rise;

Yes! the bottom of the ocean

Perhaps to its surprise.

Was lifted from the water,

Became a level plain;

Received the glorious sunshine,

The first and latter rain. 


\section{The Grand Canyon}

A river takes the drainage

Back to the restless sea,

Carves as it goes a passage

Widening gracefully and free.

"Tell me" asks my companion

"How the river" cuts its way,

Where the stars faint light is shining

In the middle of the day,

So deep below the surface,

That the sun's most dazzling ray

N'er gleams upon the water

That is beaten into spray?"

Well: then listen to the story

How in ages long ago,

The earth rose from the water

And the land began to grow.

As the earth was slowly rising, Rivers bed cut through the land, The rocks that tumbled in it The grarel, rock and sand

Scoured out and carved the basin As the rast land masses rose, And the mighty Colorado Flows where it used to flow. 
For the land continued rising And the waters cut their way Through Earth's upheaving bosom, Through granite, lime and clay.

The rising cliffs receeding From the margins of the stream; Effects of frost and rainfall On every side are seen;

For chips are falling ever, From exposed strata flanks, Roll down into the river, Leaping the waters banks,

Fall in the whirling waters, That churn the rocky mass Against the boulders lodging Within the narrow pass.

Then the great burden bearer Within its canyon grand, Bears out upon its bosom The wreckage of the land.

And in the western ocean; 'Long California's shore, The debris from Grand Canyon. Are settling more and more. 


\section{The Grand Canyon}

For near the gulf, the river

Flows by a level floor,

Spreads out upon the flood plain

The ground up mountains core. 


\section{2 'Long Superior's Dented Shore}

'LONG SUPERIOR'S DENTED SHORE

Have you ever made a journey 'long Superior's dented shore?

Where the glory of the landscape enchant one more and more;

Where the green tints of the water, and its gravel covered floor,

The surface, smooth and polished like a burnished oaken door.

The mountains on the main land grown o'er with spruces green,

While pine and whitened birches are sprinkled in between.

Out there, a mighty freighter loads ten thousand tons of ore.

Rounded islands with green woods are shrouded o'er.

Red butressed headlands, encroaching on the shore

Form lines of wondrous beauty around the lake's broad floor.

Our railway bed is blasted from the earth's foundation stone:

Granite, Gneiss, and Green-Rock in many a sobe * tone.

0 : the beauty of the hillsides, ensheathed in living green, 


\section{'Long Superior's Dented Shore 213}

While the work of the old glaciers on every side are seen;

The Age of Ice has eaten basins in the ancient rock;

While the stone upon the hillside lie in many polished block.

A glorious scene of beauty, scarce marred by liuman hand,

Few boats upon the water, no farmers till the land.

Five hundred miles we've traveled, by lake and hill, and brake,

Upon earth's rocky bosom our westward way we take.

While the gleaming surface of Superior's mighty lake

Indent the land around us, a glowing picture make,

Arrayed in living colors, a fairy isle is seen.

Red boulders strew the hillside, a background for the green.

The famous waters of Columbia's inland sea

Separate two nations of brave men true and free.

No forts on either border; no soldiers pace the shore,

No Dreadnaught plows the water, no mighty cannon roar. 


\section{4 'Long Superior's Dented Shore}

But now the sun is setting beneath the western sea.

His level rays are glowing on sheets of water free,

And in the lovely gloaming upon the watery way, The mountains change to purple, the waters turn to grey. 


\section{The Laurentian Hills}

I am riding on a railway that spans from sea to sea;

Rocking on earth's throbbing bosom, for my iron horse is free;

How the scenes stretch out before me, as the coaches eastward roll,

I am riding on the C. P. and to it I'm paying toll.

I have reached a waste of waters, Superior's mighty flood

Indent the land before me, encroach the silent wood;

For the vale, and gulch and valley, ever packed with spruces green,

Mixed with the yellow poplar; with white barked birch between.

The earth itself is covered with its own foundation rock,

Granite, Gneiss and Green Stone, in many a mighty block,

Carved and rounded by the Ice Cap, that once covered all the land:

They rise in hill and butress like some ancient castle grand.

Birches standing, with trunks as white as snow, 
And slender spires of spruce trees, in serried ranks they grow.

A gorgeous carpet underneath upon the rocks ar : spread,

The different patterns blended might form a Titan's bed.

White granite peeps above it with streaks of redish hue

With God's own arch above us! star's twinkling in the blue.

Yes! I'm riding on the bosom of the oldest land that's known,

And old Time, through countless ages, over it has ever flown,

When England's land was lifted above the ocean blue,

The Old World is not the oldest, it should be called the new.

$\mathrm{O}$ ! could rocks but tell the story their rugged cliffs have know,

They could tell us of this continent, and how its its slowly grown.

How the beds laid down by water, in ocean, river, lake

Through all the changing aeons, from these rocks their tribute take.

For the streams, (those burden bearers), on ocean floor have spread

The loads they carry ever, to deposit on her bed. 


\section{The Laurentian Hills}

Granite Boulders from the hill side, choke up the rapid stream,

They are ground by rushing water, till as pebbles they are seen,

As the river current lessens, then are pebbles ground to sand,

To be carried to the ocean, forming bars and banks so grand.

Then the life that fills the ocean, the crustacean and the shell,

When dying, left their skeletons the seas broas floor to swell.

I can see Ontario's mountains rise, where early life is seen,

The mullusk of the ocean, and the sea weeds liv. ing green.

The Laurentian Hills are rising at the margin of the sea.

While the bordering waters throbing with molluskan life so free,

The globe's thin crust is resting on the molten mass below,

Transformed, as hard as granite, on her flanks the Trenton rest

The land mass is slowing growing to the east, and south and west.

Now the water of the ocean, bring forth a countless tribe,

Of many forms of shell fish that are scattered far and wide. 
Crustaceans crowd the shore-line, and that wonderous trilobite,

Lives on through many ages till Time of chalk so white,

So Silurian rocks are added to Laurentian narrow shore,

And the Continents broad empire marches westward ever more.

\section{II.}

Devonian seas are lapping round Silurian cape and bay,

New fish life fills the waters, and over them hold sway.

Strange forms in shield and buckler, in armor polished zright,

Ganoids and other fishes show their color's in the light.

I have seen a dozen fishes, impaled on block of slate

Stand out, as carved by nature, they're lying there in state:

Seaweeds have left their impress in these endur. ing sands of Time,

Stretched out in all their measures in many a lengthening line,

For the ebb had stretched them seaward, while the fish swam 'gainst the tide,

They were swimming toward the sea-shore, while swimming they have died.

Both plants and fishes, in the old Deronian floor, 


\section{The Laurentian Hills}

After ages, tell the story, that the One we all adore,

Keeps reeord of Creation in old oceans muddy flool.

Footsteps of the Creator in ages that have fled, When a host of shells and fishes left their forms in oceans bed.

And now the bed is lifted along the eastern shore: Increasing now the land mass, round Laurentian more and more,

O: Time thou hast no limit to grasp of human mind,

Unmeasured by the intellect of any of our kind. But Time to our Creator, is like forgotten fears, "A thousand years a single day, a single day a thousand years."

And let our study of the past cause reverence for His name

Both now, and yesterday, through time, He ever is the same.

So with these simple verses we'll praise His Holy Name. 
A JOURNEY IN THE MONTH OF JUNE IN EASTERN CANADA

$\mathrm{O}$ ! the glories of a journey taken in the month of June,

When the gentle winds are sighing, and all nature is in tune:

While the fragrance of red clover, and the green tints of the trees,

Make me glad I am a rover, bathed in the eve ning breeze.

\section{II}

So all day I sit and wonder, on green plush I lay and ponder

On the glorious panorama, ever new,

And I raise my window curtain, for I'm vers, very certain,

I have never, nerer witnessed such a view.

\section{III}

O! Columbia, how I love you, where my first new breath I drew,

What lines of grace and beauty on every side you strew.

I am rocking on your bosom for my iron horse is free,

And the flowers by the hillside waft theis fragrance over me. 


\section{A Journey In June}

\section{IV}

Gazing from my open window, how my heart strings thrill, and thrill,

At the glory of the landscape I never get my fill. Canadian hills embowered with crowning woods of green,

While fields and lakes and river on either side are seen.

Now white daisies blend their colors with the darker green below,

Or the shining vellow buttercups, their golden beauties show,

Wild mustard grows in masses o'er many a lengthening row,

Add color to the wheat fields stretching out, as west we go.

\section{VI}

Now and then, a clump of roses, add their sweetness to the breeze,

And June air is gently sigling 'midst the verdure of the trees,

Oh: the plain and flood and hillside, how they swiftly come and go,

While the power of the engine rocks me gently to and fro.

\section{VII}

Yes! the scenes move out before me like the pictures in a show. 
While in the gentle gloaming, on wings I seem to go.

With wondrous lines of beauty with splendid brush so free,

For the colors of the rainbow cast their glamor over me,

\section{VIII}

Yes! the beauties of Dame Nature are most wonderfully fair,

And gazing on those beauties my soul seems free from care,

So my train swings ever westward, her coaches keeping rhyme

To the music of dear Nature that's never out of time.

\section{IX}

The birds fly up above me, and the flowers bloom below;

For God cares for the Raven, on flowers love bestow.

We have an earthly Eden from a Father's loving hand,

Angels guard us on the ocean and on the solid land,

\section{$\mathrm{X}$}

And should we mount, as eagles. on wings in the mid air : 


\section{A Journey In June}

In blue expanse of heaven, His love would guard us there.

So as the night grows darker I seek my narrow berth.

I sleep the sleep of childhood, free from the cares of earth. 



\section{INDEX}

Acme, Alberta, 34, 51, 112 , $114,128,184$

Advance Science, articulated skeletons, 57

Adventure in Kansas Chalk, 70-71

Age of Iron, 173

Reptiles, 139, 14

Alberta, 13, 25, 68, 69, 113119

Allegheny Mountains, 18

American Museum of Natural History, 24, 27, $29,30,47,52,58$, $61,62,73,94,117$, $128,139,150$

Paleontologist, the oldest, 26

Paleontology, 151, 117

Ammonites, 51

Amphibians, 68, 182-184

Ancient World, 184-190

Anchylosaurus magniventris, 94

Animals, 13

Angiosperms, 150

Another Strange Dinosaur, 120

Archelon isochyros, 26

Arizona, 66

Arlington Cemetery, 22

Armoured Dinosaurs from Kansas Chalk, 95

Armored Plant Eaters, 68

Army Building, 23

Arthur, Port, 94

Atlantic, 79, 100

Auk Great, 13

Australia, 22
Baculites, 115

Badlands, 134

Bassano, 88, 108, 109

Batracians, 96, 182

Battle Between Dinosaurs, 108

Bay Land Locked, 160

Bear Paw Shales, 109, 114118

Mountains, 112

Belly River Series 2, 5, 25, $66,68,73,96,111$, 114-116, 130

Description of, 73,74

Belongs to Pierre, 112

Benton, Fort, 111

Beresford, Admiral, of England, 87

Berlin Museum, 139

Bestrum, Mr., 91

Big Spring, 112

Black Feet Indian Reserve, 127

Boat, Flat, 101

Bog Iron Bones Enclosed in, 63

Bonebeds, Near Top and Bottom of Badlands, 84

Bones of Crested Dinosaur, 63

Boulders, Lying Around, 66

Boule, Dr., 9, 33

Bridge at Great Falls, Montana, 33

British Empire, 3 
British Museum of Natural History, 2, 9, 11, 64, 139, 169

$58,61,66,73,94-98$, $120,127,130,131$, 117,118

Camp, 62

Great Collection, 73

Brock, Dr., 7, 69

Brontosaur, 21, 56

Brooks, 92, 110, 133

Brown, Dr. Barnum, 3, 25,

Bull Berry Jelly, 90

Calgary, Alberta, 34, 36

Cambridge, Mass., 73, 132

Camp Above Happy Jack Ferry, 85

Camp, This is the Richest, 54

Campsosaurus, Found by George F. Sternberg, 84, 86, 116

Canada, 110, 134

Canadian Pacific Rwy., 73

Canadian Rockies, 34

Northern Rwy., 36

Canyon, Our Work In a, 61

Capital, 20

Carbide Used for Lights on Lake, 93

Carboniferous, 22, 180

Carnegie, Mr., 19, 29, 56

Museum, 4, 19, 21

Hall of Music, 19

Carnivore, Discovery of, 53

Excavating, 55

Loading, 55

Charlie Standing in Quarry, 55

Will Mount In Bold Relief, 58

Carniverous Dinosaurs, 139,143

Carving Out an Urn, 129
Casey, 17

Cassowary, 61

Casuarius, 61, 65, 116

Central Pacific Rwy. Co., 88

Centrosaurus, Discovered by Charles M. Sternberg, 91, 120

Centrosaurus Prepared by Geo. F. Sternberg, 122,124

Ceretops, 48, 86, 91, 105, 107,119

Chasamosaurus, $73,80,82$, $86,104,107$

Description of, 80-81

Prepared, 82

Ideal Picture, 83

Chinaman Has a Hot Dish for Us, 92

Church of England Minister, 69

Cimoliasaurus, 177

Claggett Shales, 113, 114, 11

Claosaurus, 96

Clark, Mr., Head Photographic Division, 69

Clidastes, 21, 162

Coal Mining In Indiana, 18

At Drumheller, 36

In Milk River Country, 117,130

Miners Tunnel, 135

Plants, 182

Coffee, 76

McCheche, 44

Beaver, 64, 70

Seven Mile, 4

Butte, 176

Eagle, 112

Collecting Dinosaurs, 4648

Concretions, 52, 53, 66

Conrad, 159 
Cope, Prof., 7, 11, 27, 61, S2, 111, 113-118, $120,132,134,159$, 169,184

Collection, 25, 139

Corythosaurius, George Finds Skeleton, 86, 87

Coulee, Verdegris, 129

County, Albany, IVyo., 20

Courage Needed, 64

Coutts, 34, 110

Cow Boys, 67

Island, 111, 114

Creator, For Millions of Years the, 65

Creatures Having Seed in Themselves, 65

Creek, Lance, 11,26

Plum, 14

Old Woman, 27

IVillow, 50

Bull Pond, 51

Sand, 61, 73

Rosebud, 35

Knee Hill, 35

Tributary, 35

Berry, 52, 68

One Tree, 75

Hackberry, 75, 95, 160

Hell, 94

Dog, 113-115, 121

Crested Dinos a u $\mathrm{s}$, Description of 62,67

Cretaceous, 11, 51, 53, 60, $66,114,140$

Crinoids, 164

Crocodile Bones, 68, 84, 143

Crow Indians Peserve, 33

Dakota Group, 13

Dead Lodge Canyon, 114119

Denhart Restoration, 61

Dike Volcanic, 112
Dinosaurs, 3, 98, 101, 35

Of Red Deer River, 2, 21, 139

Diplodocus Carnegie, 20, 57

Director Geological Survey, $55,58,110$

Discovely of Fossil Fish, 12

Discovery of Two Skeletons, 60,62

Specimens of Coryothsaurus, 65,66

Disney, Mr. Patrick, 87, 88

Douglass, 20,56

Dowling, D. B., 110, 117

Dreverman, Dr. F., 7

Drumheller, Alberta, 35, 44, 48, 53

Duck-Billed Dinosaurs, 7, 8,68

Eagle Sandstone, 113, 116 Easton, A. E., 3, 33, 36, 41, 48

Edgemollt, South Dakota, 5,33

Edmonton Series, 25, 51, $62,66,84,96,113$, 114,117

Of Brackish Water, 33,38

Description of, 35

Egyptians Ancient, 7

Elkader, 70

England, 87

Eryops, 185

Euoplocephalus, 66, 97

Excavation In Face of Cliff, 67

Exhibition Room, 30, 65

Faces of Bluff Covered With Cherty Fraginents, 43

Falls, Great, 111 
Fern Trees, 22

Ferry Loveland, 62

Man Stretched Wire Across River, 51, 52

Field Notes For 1913, 72

Figs, 9

Flesh Eaters, 68

Florida, 9, 177

Fluting Beautiful, 66

Fog Horn, 174

Fossil Leaves Locality, 53

Fox Hills, 114

Frankfort on the Main, 7

Frenchman, 175

Galyean, Hope to Reach House, 75, 76

John, 76

Geological Survey of Canada, 2, 14, 15, 21, 33, $48,53,68,69,80$

Gallery, 12

And Paleontology, 114

Germany, Made in, 68

Gibbs, Mr. Hugh, 26

Gidley, Mr., 22, 56

Gila Monster, 60

Gilmore, C. W., 22, 56

God, Creative Power of, 65

Goldsmith's Poem, 170

Gorges Deep, 115

Gorgosaurus li bratus, Lambe, 58, 59-60, $75,107-110$

Gothic Towers, 72

Gove County, Kansas 70

Granger, Mr., 58

Great Northern Rwy., 111

Gryposaurus, of Lambe, $68,73,75,118$

Hadrosaurus, 96

Hall of Fossil Vertebrates, 67

Hall, Steve, Hotel, 52

Haploscapha, 159
Happy Jack Ferry, 94, 102, 109

Hatcher, Dr. J. B., 17

Hawkins, Waterhouse, 57

Head Collector and Preparator, 33

Holland, Dr., 55

Holy Ground, Our Laboratory, 65

Horizon, We Got in a New, 52

Hunting Dinosaurs, 78

Big Game, 94

Ideal Pictures of Edmonton Times, 38-41. 135-155

Duck-Bills, 144, 147

Cretaceous Life, 160179

Tylosaur, 160, 161

Pteranodont, 114

Portheus, 169

Snout Fishes, 177-178

Iguanodonts, 57

Illinois, 16,17

Indiana, 17

Indianapolis, 18

Indian Traveled on Trail of, 67

Inoceramus Shell, 25, 177

International Line, 27, 34, 129

Ireland's Empress, 174

Jackson, Mr., 87

Jasperson, 18

Jehu Rode Like, 70

Jessup, Morris, 25

Johnson, Mr., 87

Judith River Post Office, $113,114,134,142$

Country, 119

Kansas, 159, 162, 165 


\section{Index}

Kansas Chalk, 1, 12, 25, 27, $54,95,97,100$

Western, 11, 132

Keetewin Steamer, 93

Kendall, Montana, 116

Knowlton, Dr. F. H., 129, 166

Kindness of Directors, Dr. Brock and Mr. R. G. McConnell, 69

Kritosaurus, 118

Labyrinth of Intricate Gorges, 47

Lady of the North, 3

Laelaps, 57

Lambe, Mr., 30, 58, 61, 62, $65,68,72,76,88,96$, 118,120

Lance Beds, 11, 96, 128

Land Slides, 50

Laramie, 11

Lawrence, Kansas, 2, 13, 16,162

Leidy, Prof., 96, 118

Lepidodendron, 180

Lethbridge, Alberta, 34

Life of a Fossil Hunter, 17,118

Light Houses, 97

Livingston's Ranch, 70

London Illustrated News, 11,169

Loveland Ferry, 96

Lull, Prof., 26, 34

Lusk, Wyoming, 14

Mammalian Remains, 69

Marsh, Prof., O. C., 21, 26, $40,65,86,96,182$

Matthew, Dr., 58

Maud, 156-178, 183, 184, 187

McBride's House, 76

McConnell, Mr. R. G., 127
McGee, Jack, 49, 52, 55

Dan, 44,47

McKeon Ranch in Wyom ing, 4

McNickle, Port, 93, 172

Medicine Hat, 132, 133

Miller, Mr., 181

Moa, the Great, 13

Monarch, Under a, 2

Monster Fish, 12

Montana, 121, 129, 135, 142

Monument Rocks, 70

Morophus, 21

Mosasaurian Bay, 164, 167

Mosasaurus, 162,164

Motor Boat, 85

Mounting Trachod on Skeleton, 44, 64, 65, 84

Titanotherium Skeleton, $14,28,29$

Two Skulls of Centrosaurus, 122

Charlie's Gorgosaurus, 48

Moving Pictures, 92

Munich, Bavaria, 139

Museum of Comparative Zoology, 161

Museum of Kansas University, 162

Music Hall, 18

Myledaphus, 84

Narrow Escape When Men Loaded Trachodon, 48

Natural History Museum Paris, 33

Nature's Heart, 65, 165

Nevada, 56

New Mexican Trachodont, 72

New York, 26 
New Zealand, 60

Niobrara County, Wyoming, 14

Nolan, Dr., 57

Northern Lights, 93

Ohio, 18

Oligocene, Sculptury of the, 14,15

Open Mounts the Process, 37,58

Oregon, 25

Osborn, Prof. H. F., 25, 150,153

Ostrea congesta, 15

Outlying Butte, 66

Oxford University, 87

Paleontological Museum, 19

Paleontology, 8

Palmetto Palm, 9

Paradise of Dry Bones, 26

Parks, Prof., 92

Paris, 9, 13, 48 Museum, 134

Patience Necessary in Preparation of Dinosaurs, 64

Pennsylvania, 18

Route, 16

Avenue, 23

Permian Beds of Texas, $75,132,182,187$

Peterson, Mr., 58

Petrified Bones of DuckBills Poorly Preserved, 63

Photographs Taken by George, Charles and Levi Stermberg, 69

Picture of Carniverous Dinosaur Life, 60

Early Lance Creek Beds, 9

Picture of Centrosaurus, 126
Pierre, Fort, 34, 50, 51, 113,114

Pillars, Mush-Room-Like, 66

Pittsburgh, 18, 22, 55, 162

Plaster Process of Protecting Fossils, 45

Platanus, 128

Platecarpus, 16

Plated Dinosaurs, 88, 90, 95

Plesiosaur, 175, 177

Pleistocene, 50

Poems, 200-223

Poets Tribute to Soldier Dead, 24

Port Arthur, 94, 172

Portheus, 11, 19, 25, 171

Pose of Saurians, 60

Prairie Margin Slides Down, 42

Preparing, George at Work, 123

Proceedings, Kansas Acadeniy, 94

Proceedings Society, 3

Problem I, The Environment of Dinosaurs, $34,40,41$

II, How Did the River Cut Its Gorge? 37, $38,42,43$

Professol Sternberg, 13

Prosaurolophus, 66, 86

Protostega gigas, 21

Pycraft, 11, 12

Pyramids Fluted, 72

Quinter, Kansas, 33, 70

River, Waskaskia, 17

Ohio, 18

Cheyenne, 5, 10

Red Deer, 25, 42, 43, $54,68,69,96,114$, $116,132,133$ 
Milk, 122, 127-129

Judith, 109-118

Missouri, 112, 115-119, 129,142

Mississippi, 16

John Day, 25

Beily, 94, 98, 114

St. Lawrence, 100

Red Deer, Dinosaurs, 64,125

Trip Down, 49-53

Big Wichita, 181

Swift Current, 109

Recession of Cliffs, 41

Red Letter Day, 43

Royal Museum, Toronto, 93

Redwood Leaves, 43

Sailors, Funeral of the Maine, 23

Scenery on Red Deer River, 64

Schuchert, Professor, 26

Scientific Men, Mistakes of, 80

Scott, Prof. W. B., 57

Scott's Famous Poem, 141

Scow Building of, etc., 49, $85,88,91$

Seamen's Hills, 14

Secretary Academny of Science, 57

Senckenberg Museum, 7, 9, 98

Shaw, The Ferry Man, 133

Siliceous Concretions, 67

Siren Sounds Alarm, 94

Site, Moved Camp Down to new, 54

Skeleton Platecarpus, 162

Skull of Crested Dinosaur, 63

Soft Soap, After a Rain Like, 43

Soliders of the Union, 28
Soo Locks, 94

South Dakota, 26

Sphenodon, 60

Stanton, Mr., 114

Station, Milk River, 128

Stegosaur, 22, 56, 68, 94, 95

St. Elmo's Fire First Seen on Land, 71,72

Stephanosaurus of Lambe, 65,67

The Nearly Complete Skeleton, 65

Described, 62-65

Sternberg, General George M., 22

Charles H., 16, 65, 68, $72-3-4,31,52, \quad 54$, $84,85,95,122,127$

George F., 16, 25, 27, $33,34,47,48,69$, $73,74,3,9,11-14$, $52,54,64,69,77,83$, 86

Charles M., 16, 27, 3, $5,9,14,25,49,51-$ $58,62,84,85,86,88$, 120-129

Levi, 2, 33, 71-75, 45, $45,49,54,14,124$

Charles H., A Collector for Fifty Years, 27

Charles M., Discovers Trachodont Skeleton, 43

Steveville, 73, 77, 52, 78, 102,133

St. Louis, 16

Storm, Great Thunder, 70, 71

Styracosaurus, 101-102

Story of An Old River Bed, 14

Of the Discovery of 
Charlie's Trachodon, 5

Styracosaurus, 102-107

Summary of the Geological Survey, 68

Superior, 94, 93

Sweet Grass, Montana, 34

Swift Current, 88

Teeming East, 16

Terre Haute, 17

Texas, 75, 181

Theropoda, 68

Timber, Destruction of, 18

Titanotherium, 14, 27, 28

Trachodon, 57, 62, 79, 84, 118

Found by Charles M. Sternberg, 67

A Swimming, 34

A Feeding, 39

Description of, 39, 40

Death From Carnivor annectens, Marsh, 41

Trail Cowboys Traveled on on it, 67

Princeton, 67

Trees Palms, Redwoods, Sycamores, Figs, Magnolias, 33

Trego County, Kansas, 16

Triceratops, 33, 81, 104

Trip to the East, 16-19

Pittsburgh, 66

Washington, 58

Philadelphia, 57

Toronto, Canada, 93

Tubingen, University, 25

Turtles, 68

Found by George F., 77

Tylosaurus, 13, 160-162

Tyrant of the Everglades, 75
Unde1. Ground Channels, 63

Union Jack, 3

Uintacrinus socialls, 165

United States, 3

National Museum of the, 55

Upper Cretaceous, 13

Urn, Carving An, 129

Utterback Specimen, 4

Vandalism, 176

Valley of Red Deer River, 35

Milk River, 129

Vassar College, 162

Victoria Memorial Museum, $2,7,9,10,14$, $45,53,125$

Venus, 38

Verdegris Coulee, 129

Vertebrate Paleontologist, $61,80,176$

Paleontology, 24

Fossils, 33

Views of Old Paleontologists, 8

Vulcanism, 112, 113, 115, 129

Ward, Dr., 166

Washington, 22, 56

Weed, 110

We Explore Dead Lodge Canyon, 49

Weiland, Dr., 26, 176, 177

We Spy Out the Land, 53

Western Kansas, 150

Williston, Dr. S. W., 26, 176,177

Wilson, 166

Wonders of the Permian, 180-199

Work on Charlie's Gryposaurus, 72

Wyoming, 35, 96, 122, 149

Yale, 26, 95, 176 


\section{"THE LIFE OF A FOSSIL HUNTER"}

\section{IS OUT OF PRINT.}

I own the electrotypes, halftones and copyright and will publish a new edition on receipt of a hundred subscriptions at $\$ 1.75$ each postpaid.

\section{Charles H. Sternberg,}

Author.

A few extracts from Reviews of "The Life of a Fossil Hunter."

Chicago nerald, March 20th, 1909.

"Any body will instantly feel the spell of interest in Mr. Sternberg's autobiography 'The Life of a Fossil Hunter.' Mr. Sternberg writes simply, unpretentiously, entertainingly, and there runs all througl his book a curious union of scientific devotion and religious reverence that is as unusual as it is charming."

San Francisco Argonaut, June 5th, 1909.

"There are few hunters of live game who can tell so good a story, who has seen so much adventure, or experienced so many escapes. Such a record would in any case be interesting, but it becomes fascinating from the exuberance of its style and hearty enthusiasm that animates every page."

\section{Boston Living Age, March 20th, 1909.}

"His name, as affixed to his specimens, is the only witness to his labors which will remain after him, except the work of three sons whom he has trained to follow in his footsteps; but he has been happy and his single-hearted story is a book to -enew our faith in man's capacity to work for pure delight in worls."

Interior, Chicago, June 17th, 1909.

"But he not only stuck to his self-imposed task but raised at whole family of boys, every one of whom took to fossil hunting as a duckling does to water. Best of all, to the Christian reader, it will seem the author kept his faith in God and the rible unimpaired, and his pages are full of ascriptions of praise to the Maker of heaven and earth."

Lawrence Gazette, March 8th, 1909.

"A remarkable book. The author has a way of telling things that is charming because of its simplicity. He uses scientific terms only when necessary, and a child could read and understand this book." 




Date Due

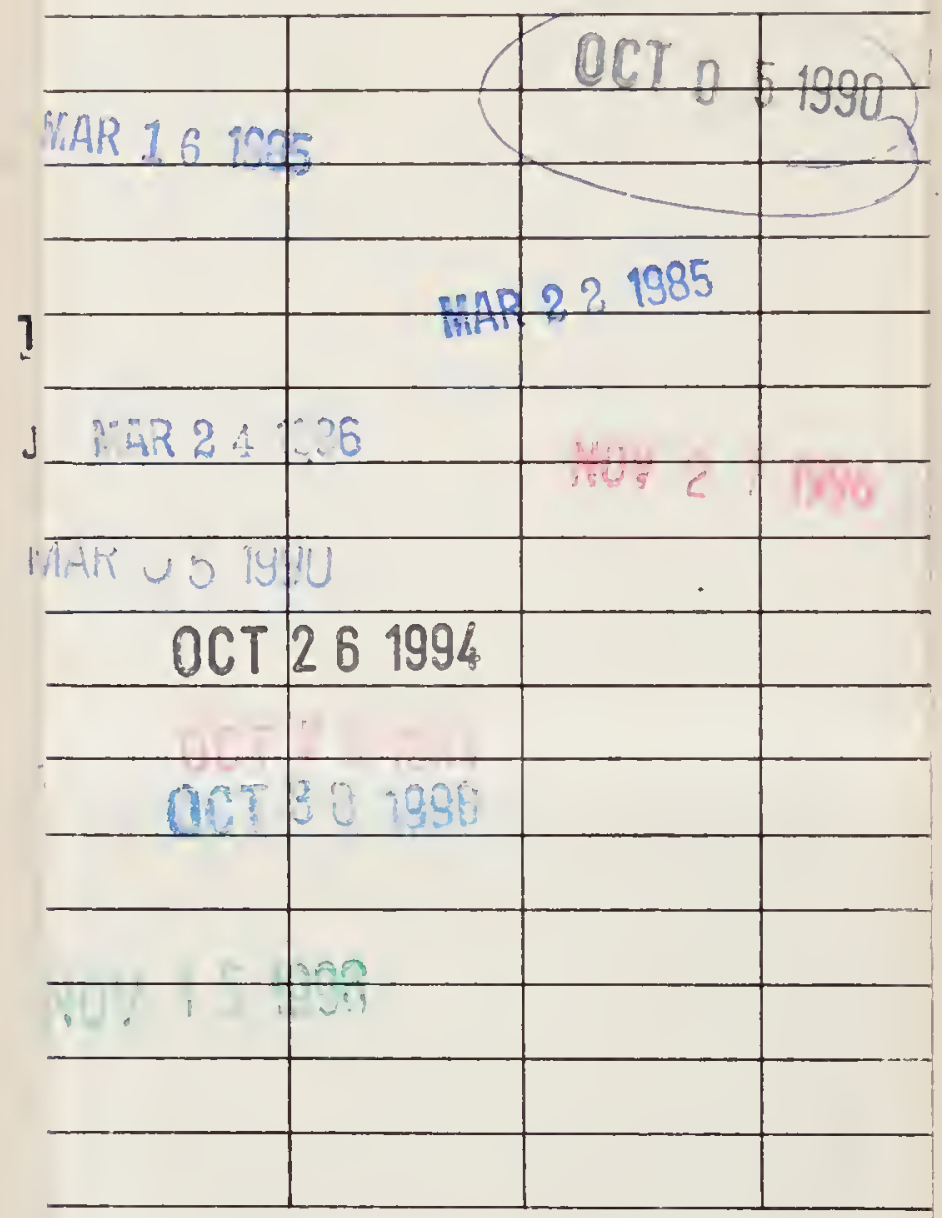

p 


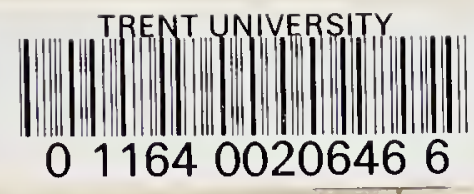

\section{QE707 .S8A4}

Sternberg, Charles Hazelius

Hunting dinosaurs in the bad lands of the Red Deer River, Alberta, Canada.

DATE $=\frac{\text { ISSUED TO }}{301962}$


